Graduate Theses, Dissertations, and Problem Reports

2021

The Three Piano Sonatas by José de Almeida Penalva

Heron Alvim Moreira Mr.

Follow this and additional works at: https://researchrepository.wvu.edu/etd

Part of the Music Performance Commons, Music Practice Commons, and the Music Theory Commons 


\title{
The Three Piano Sonatas by José de Almeida Penalva
}

\author{
Heron Alvim Moreira
}

Research project submitted to the College of Creative Arts at West Virginia University in partial fulfillment of the requirements for the degree

Doctor of Musical Arts in Collaborative Piano

\author{
Peter Amstutz, DMA Chair and Research Advisor \\ Lucy Mauro, DMA \\ Matthew Heap, PhD \\ John Goldwasser, PhD
}

School of Music

Morgantown, West Virginia

2021

Keywords: Penalva, Priest composer, Brazilian piano sonata, Heron Alvim Moreira 


\section{Abstract \\ The Three Piano Sonatas by José de Almeida Penalva \\ Heron Alvim Moreira}

This research project discusses the three piano sonatas by José de Almeida Penalva (1924-2002), a priest and composer from the southern region of Brazil, who lived most of his life in the city of Curitiba, in Paraná state.

Along with overall information about the composer's life and general output, the reader will find brief discussions of Penalva's keyboard works, along with comprehensive formal analyses of his three piano sonatas.

Sonata no. 1 (1970, chronologically the second to be written) appears in one large movement that reveals two distinct sections. Its language is atonal and its first section displays sonata-allegro form. The work employs twelve-tone technique along with folklore elements from the Brazilian genres seresta and desafio.

Sonata no. 2 (1960, chronologically the first to be written) employs free modal language in each of its three contrasting movements. According to Penalva's own indications, the first movement draws on the styles of George Gershwin and Béla Bartók, the second movement refers to Camargo Guarnieri (Brazilian composer who lived from 1907-1993), and the third evokes Anton Webern. Although no material from these composers is directly quoted, it is possible to recognize their stylistic traits within the respective movements.

Sonata no. 3 (1991) is the most complex and technically demanding among the three sonatas. It employs free atonal language and displays three highly contrasting movements. Some folk elements also appear, as for example the third movement's energetic rhythm, which clearly suggests the Brazilian popular genre baião.

This research project is the first part of a larger undertaking that the author hopes will eventually include a commercial recording of all three sonatas, along with preparing a new performance edition that takes into account the many discrepancies among the composer's manuscripts and the currently available editions. It is the author's sincere hope that this research can help to popularize this repertoire, which is colorful and satisfying, but remains relatively unknown, both in Brazil and beyond. 


\section{Acknowledgments}

This research is dedicated to the loving memory of my brother, Marconi Alvim Moreira.

Thanks so much to my mother and, in memoriam, my father. You have both supported me in so many ways throughout my entire life.

Huge thanks to my family (my wonderful wife, Junia, and our sons Igor and Daniel) for encouraging me while I was in Morgantown and you were in Brazil without your husband and dad. I hope that someday I can repay you for your patience and your huge effort.

Thanks to Junia's parents, Zulmira H. Canton-Rocha and Luis Carlos Rocha (in memoriam), and Elizabeth Barbosa de Souza for your immeasurable assistance to my family during the time I was abroad for study.

My gratitude to all my WVU faculty members and also to my colleagues there, especially Timothy Richards, Agatha Holland, Xiaohan Hu, Akina Kondoh, Anthony Gray, Ji-Yeon Lee, Jesse Preis, and Matthew Cyphert. I am particularly grateful to my skilled and devoted English professor, Mrs. Kristen Williams, for your wonderful support with language matters during my stay in Morgantown.

Sincere thanks also to my colleagues in Brazil, without whom I would certainly be in serious trouble: Oiliam Lanna (composition and conducting), Miguel Rosselini (piano), Celina Szrvinsk (piano) and Luiz Senise (in memoriam, piano). Thank you to Waltson Ginju Magalhães Tanaka for all your help with scoring for my new editions of the three Penalva piano sonatas. I also feel enormous gratitude to my early piano professors, Marta Alvim and Berenice Menegale, for their precious and unforgettable piano classes.

Last, but not least, my many thanks to Dr. Amstutz, my professor and advisor--and also my friend and soul-family there in the U.S.A.--for your immeasurable support during my piano and dissertation classes, and during all the rest of my time there for my doctoral studies. I appreciate all your friendship and care. In bad times or good times, you were always there--and I will always be grateful to you. 


\section{Table of Contents}

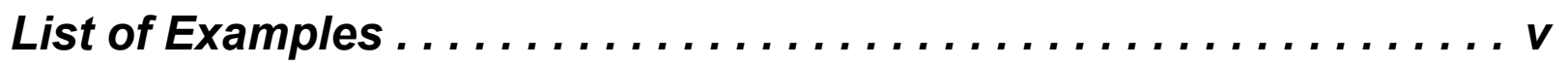

Chapter One - Research Object ................... 1

1.1 Statement of Topic and Supporting Literature ............... 1

1.2 José de Almeida Penalva: Life and Work ................. 5

Chapter Two - Musical Output . . . . . . . . . . . . . 10

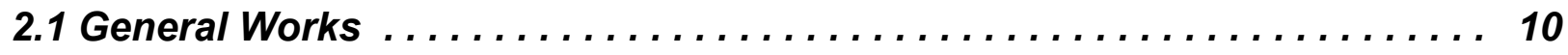

2.2 Pianistic Repertoire . . . . . . . . . . . . . . . . . . . . 11

2.2.1 General Considerations . . . . . . . . . . . . . . . . . . . 11

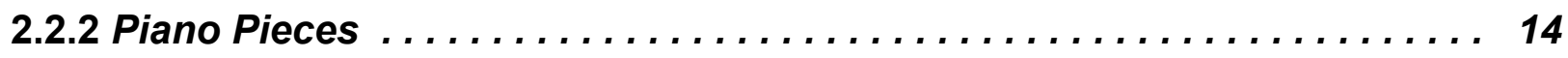

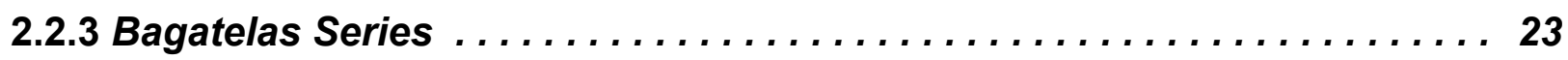

Chapter Three - The Piano Sonatas . . . . . . . . . . . . 28

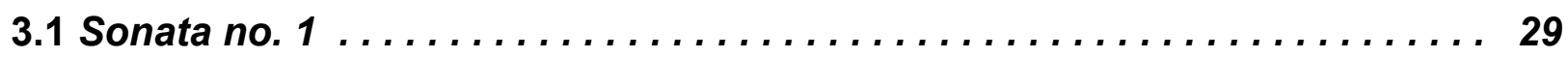

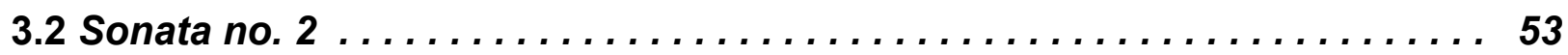

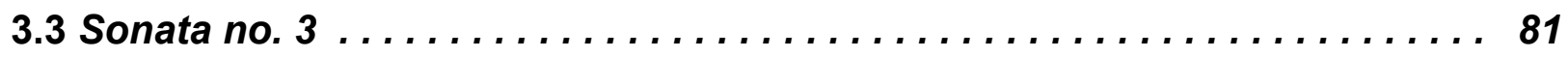

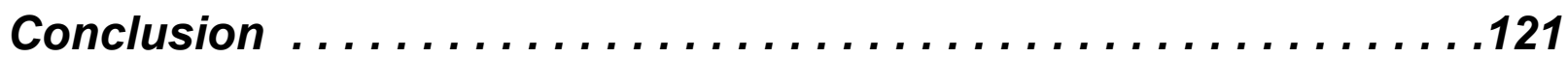

Appendix 1 - Penalva Sonata No. 1 (Manuscript) . . . . . . . . . 123 Appendix 2 - Penalva Sonata No. 2 (Manuscript) . . . . . . . . . . 131 Appendix 3 - Penalva Sonata No. 3 (Manuscript) . . . . . . . . . . 144 Appendix 4 - Penalva Bagatelas . . . . . . . . . . . . . . . . . . . 159 Appendix 5 - Glossary of Portuguese Musical Terms . . . . . . . 171

Bibliography . . . . . . . . . . . . . . . . . . . . 175 


\section{List of Examples}

Chapter Two - Musical Output . . . . . . . . . . . . . . 10

Figure 1: Piano works by Penalva $\quad 13$

Example 1: Penalva's Bagatela (1999), manuscript (currently, Bagatela I) 23

Example 2: Excerpt of Penalva's Bagatela VI (2000), manuscript 25

Example 3: Excerpt of Penalva's Bagatela II (1999), manuscript 26

Example 4: Excerpt of Penalva's Bagatela IV (1999), manuscript 26

$\begin{array}{ll}\text { Figure 2: Bagatelas for piano by Penalva } & 27\end{array}$

Chapter Three - The Piano Sonatas . . . . . . . . . . . . 28

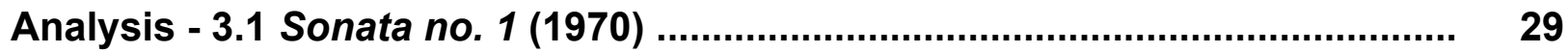

Example 1: Penalva's Piano Sonata no. 1 (1970). H. A. Moreira's version (2020), mm. 1-8 30

Example 2: Penalva's Piano Sonata no. 1 (1970). H. A. Moreira's version (2020), mm. 1-11 31

Example 3: Penalva's Piano Sonata no. 1 (1970). H. A. Moreira's version (2020), mm. 8-14 32

Example 4a: Penalva's Piano Sonata no. 1 (1970). H. A. Moreira's version (2020), mm. 15-18 33

Example 4b: Penalva's Piano Sonata no. 1 (1970). H. A. Moreira's version (2020), mm. 19-24 34

Example 5: Penalva's Piano Sonata no. 1 (1970). H. A. Moreira's version (2020), mm. 22-28 35

Example 6: Penalva's Piano Sonata no. 1 (1970). Ricordi's edition (1972), mm. 29-33 36

Example 7: Penalva's Piano Sonata no. 1 (1970). H. A. Moreira's version (2020), mm. 34-39 36

Example 8: Penalva's Piano Sonata no. 1 (1970). H. A. Moreira's version (2020), mm. 34-44 37

Example 9: Penalva's Piano Sonata no. 1 (1970). H. A. Moreira's version (2020), mm. 45-54 38

Example 10: Penalva's Piano Sonata no. 1 (1970). H. A. Moreira's version (2020), mm. 55-58 38

Example 11: Penalva's Piano Sonata no. 1 (1970). H. A. Moreira's version (2020), mm. 59-65 39

Example 12: Penalva's Piano Sonata no. 1 (1970). H. A. Moreira's version (2020), mm. 66-68 40 
Example 13: Penalva's Piano Sonata no. 1 (1970). H. A. Moreira's version (2020), mm. 66-74 40

Example 14: Penalva's Piano Sonata no. 1 (1970). H. A. Moreira's version (2020), mm. 71-83 41

Example 14b: Penalva's Piano Sonata no. 1 (1970). H. A. Moreira's version (2020), mm. 12-14 42

Example 15: Penalva's Piano Sonata no. 1 (1970). H. A. Moreira's version (2020), mm. 79-87 42

Example 1: Penalva's Piano Sonata no. 1 (1970). H. A. Moreira's version (2020), mm. 84-9 44

Example 2: Penalva's Piano Sonata no. 1 (1970). H. A. Moreira's version (2020), mm. 88-94 44

Example 3: Penalva's Piano Sonata no. 1 (1970). H. A. Moreira's version (2020), mm. 95-103 45

Example 4: Penalva's Piano Sonata no. 1 (1970). H. A. Moreira's version (2020), mm. 101-111 46

Example 5: Penalva's Piano Sonata no. 1 (1970). H. A. Moreira's version (2020), mm. 104-114 47

Example 6: Penalva's Piano Sonata no. 1 (1970). H. A. Moreira's version (2020), mm. 108-118 48

Example 7: Penalva's Piano Sonata no. 1 (1970). H. A. Moreira's version (2020), mm. 112-125 49

Example 8: Penalva's Piano Sonata no. 1 (1970). H. A. Moreira's version (2020), mm. 126-128 51

Example 9: Penalva's Piano Sonata no. 1 (1970). H. A. Moreira's version (2020), mm. 130-137 51

Example 10: Penalva's Piano Sonata no. 1 (1970). H. A. Moreira's version (2020), mm. 138-140 51

Example 11: Penalva's Piano Sonata no. 1 (1970). H. A. Moreira's version (2020), mm. 145-148 51

Example 12: Penalva's Piano Sonata no. 1 (1970). H. A. Moreira's version (2020), mm. 148-151 52

3.2 Sonata no. 2 (1960) .............................................................................. 53

Example 1: Penalva's Piano Sonata no. 2 (1960). Manuscript's 1st movement (moderato), mm. 1-4 55

Example 2: Penalva's Piano Sonata no. 2 (1960). Manuscript's 1st movement (moderato), B theme (mm. 5-10) and transition (mm. 8-10) 56

Example 3: F. Chopin's "Preludes op. 28" no. 2, mm. 1-5 56

Example 4: Penalva's Piano Sonata no. 2 (1960). Manuscript's 1st movement (moderato), mm. 9-19. B1 theme (mm. 10-17)

Example 5: Penalva's Piano Sonata no. 2 (1960). Manuscript's 1st movement (moderato), $\mathrm{mm} .43-46$

Example 6: Penalva's Piano Sonata no. 2 (1960). Manuscript's 1st movement (moderato), mm. 20-26.

B2 theme (mm. 20-26) 59 
Example 7: Penalva's Piano Sonata no. 2 (1960). Manuscript's 1st movement (moderato), mm. 27-38.

Development's first section D1 (mm. 28-36)

Example 8: Penalva's Piano Sonata no. 2 (1960). Manuscript's 1st movement (moderato), mm. 35-46.

Development's second section D2 (mm. 37-45)

Example 9: Penalva's Piano Sonata no. 2 (1960). Manuscript's 1st movement (moderato), mm. 63-75 62

Example 1: Penalva's Piano Sonata no. 2 (1960). Manuscript's 2nd movement (Andante cantabile), mm. $1-11$

Example 2: Penalva's Piano Sonata no. 2 (1960). Manuscript's 2nd movement (Andante cantabile), mm. 38-48

Example 3: Penalva's Piano Sonata no. 2 (1960). Manuscript's 2nd movement (andante cantabile), mm. 9-19 (transition to B section)

Example 4: Penalva's Piano Sonata no. 2 (1960). Manuscript's 2nd movement (andante cantabile), mm. 16-33 (B section)

Example 5: Penalva's Piano Sonata no. 2 (1960). Manuscript's 2nd movement (andante cantabile), mm. 34-48 (A' section)

Example 6: Penalva's Piano Sonata no. 2 (1960). Manuscript's 2nd movement (andante cantabile), mm. 9-26

Example 7: Penalva's Piano Sonata no. 2 (1960). Manuscript's 2nd movement (andante cantabile), mm. 11-13)

Example 1: Penalva's Piano Sonata no. 2 (1960). Manuscript's 3rd movement (rondó allegro), mm. 1-11

Example 2: Penalva's Piano Sonata no. 2 (1960). Manuscript's 3rd movement (rondó allegro), mm. 7-26.

B1 subsection (mm. 10-21)

Example 3: Penalva's Piano Sonata no. 2 (1960). Manuscript's 3rd movement (rondó allegro), mm. 19-40. B2 subsection (mm. 22-35)

Example 4: Penalva's Piano Sonata no. 2 (1960). Manuscript's 3rd movement (rondó allegro), mm. 34-47. B3 subsection (mm. 35-47)

Example 5: Penalva's Piano Sonata no. 3 (1991). Manuscript's 3rd movement (agitato-rondó), mm. 1-4

Example 6: Penalva's Piano Sonata no. 2 (1960). Manuscript's 3rd movement (rondó allegro), mm. 58-90. C section (mm. 58-86) 
Example 7: Penalva's Piano Sonata no. 2 (1960). Manuscript's 3rd movement (rondó allegro), mm. 91-121. D section (mm. 97-117)

Example 8: Penalva's Piano Sonata no. 2 (1960). Manuscript's 3rd movement (rondó allegro), mm. $122-135$

Example 9: Penalva's Piano Sonata no. 2 (1960). Manuscript's 3rd movement (rondó allegro), final refrain (mm. 136-142)

3.3 Sonata no. 3

Example 1: Penalva's Piano Sonata no. 3 (1991). Manuscript's 1st movement (allegro), mm. 1-5

Example 1a: Penalva's Piano Sonata no. 3 (1991). Manuscript's 1st movement (allegro),

p. 1, footnote

Example 2: Penalva's Piano Sonata no. 1 (1970), Ricordi's edition (1972), mm. 1-7.

A theme (mm. 1-5)

Example 3: Penalva's Piano Sonata no. 2 (1960). Manuscript's 1st movement (moderato), mm. 1-4. A theme

Example 4: Penalva's Piano Sonata no. 3 (1991). Manuscript's 1st movement (allegro), mm. 6-7.

Transition to $\mathbf{B} 1$ theme

Example 5: Penalva's Piano Sonata no. 1 (1970). Ricordi's edition (1972), mm. 19-24

Example 6: Penalva's Piano Sonata no. 3 (1991). Manuscript's 1st movement (allegro), mm. 8-16. B theme (mm. 8-14)

Example 7: Penalva's Piano Sonata no. 3 (1991). Manuscript's 1st movement (allegro), mm. 14-18. Transition to $\mathbf{C}(\mathrm{mm} .15-17)$

Example 8: Penalva's Piano Sonata no. 3 (1991). Manuscript's 1st movement (allegro), mm. 17-26. C theme (mm. 15-25)

Example 9: Penalva's Piano Sonata no. 3 (1991). Manuscript's 1st movement (allegro), mm. 21-30. C2 theme (mm. 22-30). Its second part ( $\mathrm{mm} .26-30)$ works as a transition to the development

Example 10: Penalva's Piano Sonata no. 3 (1991). Manuscript's 1st movement (allegro), mm. 31-39 91

Example 11: Penalva's Piano Sonata no. 3 (1991). Manuscript's 1st movement (allegro), mm. 40-46 92 
Example 12: Penalva's Piano Sonata no. 3 (1991). Manuscript's 1st movement (allegro), mm. 47-50 92

Example 13: Penalva's Piano Sonata no. 3 (1991). Manuscript's 1st movement (allegro), mm. 34-42 93

Example 14: Penalva's Piano Sonata no. 3 (1991). Manuscript's 1st movement (allegro), mm. 8-10 93

Example 15a: Penalva's Piano Sonata no. 3 (1991). Manuscript's 1st movement (allegro), mm. 40-46 96 Example 15b: Penalva's Piano Sonata no. 3 (1991). Manuscript's 1st movement (allegro), mm. 37-42. Development's transition (mm. 39-40)

Example 16: Penalva's Piano Sonata no. 3 (1991). Manuscript's 1st movement (allegro), mm. 47-50) 97

Example 17: Penalva's Piano Sonata no. 3 (1991). Manuscript's 1st movement (allegro), mm. 51-61 98

Example 18: Penalva's Piano Sonata no. 3 (1991). Manuscript's 1st movement (allegro), mm. $62-6599$

Example 19: Penalva's Piano Sonata no. 3 (1991). Manuscript's 1st movement (allegro), mm. 88-91 99

Example 1: Penalva's Piano Sonata no. 3 (1991). Manuscript's 2nd movement (andante), mm. 1-6 101

Example 2: Penalva's Piano Sonata no. 3 (1991). Manuscript's 1st movement (allegro), mm. 37-39.

Development's transition

Example 3: Penalva's Piano Sonata no. 3 (1991). Manuscript's 2nd movement (andante), mm. 4-8 102

Example 4: Penalva's Piano Sonata no. 3 (1991). Manuscript's 1st movement (allegro), mm. 1-3 102

Example 5: Penalva's Piano Sonata no. 3 (1991). Manuscript's 2nd movement (andante), mm. 7-14 103

Example 6: Penalva's Piano Sonata no. 3 (1991). Manuscript's 1st movement (allegro), mm. 37-42 104

Example 7: Penalva's Piano Sonata no. 3 (1991). Manuscript's 2nd movement (andante), mm. 15-17

Example 8: Penalva's Piano Sonata no. 3 (1991). Manuscript's 2nd movement (andante), mm. 18-22

Example 9: Penalva's Piano Sonata no. 3 (1991). Manuscript's 2nd movement (andante), mm. 25-26

Example 10: Penalva's Piano Sonata no. 3 (1991). Manuscript's 2nd movement (andante), mm. 29-31

Example 11: Penalva's Piano Sonata no. 3 (1991). Manuscript's 2nd movement (andante), mm. 41-43 
Example 1: Penalva's Piano Sonata no. 3 (1991). Manuscript's 3rd movement (agitato-rondó), mm. 1-13

Example 2: Penalva's Piano Sonata no. 3 (1991). Manuscript's 3rd movement (agitato-rondó), mm. 14-18

Example 3: Penalva's Piano Sonata no. 3 (1991). Manuscript's 3rd movement (agitato-rondó), mm. 19-22

Example 4: Penalva's Piano Sonata no. 3 (1991). Manuscript's 3rd movement (agitato-rondó), mm. 25-26

Example 5: Penalva's Piano Sonata no. 3 (1991). Manuscript's 3rd movement (agitato-rondó), mm. 27-32

Example 6: Penalva's Piano Sonata no. 3 (1991). Manuscript's 3rd movement (agitato-rondó), $\mathrm{mm} .33-44$

Example 7: Penalva's Piano Sonata no. 3 (1991). Manuscript's 3rd movement (agitato-rondó), mm. 41-56

Example 8: Penalva's Piano Sonata no. 3 (1991). Manuscript's 3rd movement (agitato-rondó), mm. 61-67

Example 9: Penalva's Piano Sonata no. 3 (1991). Manuscript's 3rd movement (agitato-rondó), mm. 61-62

Example 10a: Penalva's Piano Sonata no. 3 (1991). Manuscript's 3rd movement (agitato-rondó), mm. 66-73

Example 10b: Penalva's Piano Sonata no. 3 (1991). Manuscript's 3rd movement (agitato-rondó), mm. 74-76

Example 11: Penalva's Piano Sonata no. 3 (1991). Manuscript's 3rd movement (agitato-rondó), mm. 77-84

Example 12: Penalva's Piano Sonata no. 3 (1991). Manuscript's 3rd movement (agitato-rondó), mm. 81-92

Example 13a: Penalva's Piano Sonata no. 3 (1991). Manuscript's 3rd movement (agitato-rondó), mm. 89-96

Example 13b: Penalva's Piano Sonata no. 3 (1991). Manuscript's 3rd movement (agitato-rondó), mm. 97-98 
Example 14: Penalva's Piano Sonata no. 3 (1991). Manuscript's 3rd movement (agitato-rondó), mm. 99-110

Example 15: Penalva's Piano Sonata no. 3 (1991). Manuscript's 3rd movement (agitato-rondó), mm. 107-111

All musical examples are reproduced with full permission from the copyright owners. 


\section{Introduction}

"Enganam-se os homens ao julgar-me

Sou apenas um homem, nem melhor nem pior que os outros

Mas sinto-me capaz de decidir meus caminhos em qualquer direção

A favor ou contra quem e o que

De encontrar sem covardia o que fazer e como, dos anos que me serão dados

Entretanto, apenas um homem nem pior nem melhor

Não enfrentarei a espada do Arcanjo

Quem como Deus?"

Poem by José Penalva'

"Men are mistaken in judging me

I'm just a man, neither better nor worse than anyone else

But I feel able to decide my paths in any direction, in favor of or against whomever or whatever

Finding without cowardice what and how to do during the years that will be given me However, only a man, neither worse nor better

I will not face the Archangel's sword

Who could compare to God?"

\footnotetext{
${ }^{1}$ Poem by Father José de Almeida Penalva ("José Penalva, O Mestre Da Música” Parte 1), https://www youtube.com/watch? $v=K U z E Z F w 8 C u w$. Translation by Heron Alvim Moreira.
} 


\section{Statement of Topic and Supporting Literature}

Although most of Penalva's output consists of vocal works (solo voice and piano, voice with other instruments or orchestra, or choral pieces with and without orchestra), the three piano solo sonatas have become established as a prominent portion of the composer's repertoire. Due to the specific moments they were respectively conceived, these sonatas reflect the main compositional steps of Penalva's musical journey, being representative not just within his pianistic repertoire but also regarding his overall musical output.

The first academic work about Penalva's piano pieces is by Carmen Célia Fregoneze (1992). ${ }^{2}$ This is a very important document, in part because it was the first attempt to make this repertoire known to the musical community in Brazil at that time. Obviously, those works which Penalva composed after 1992 could not be discussed in Fregoneze's dissertation.

The second academic work about the topic is my own master's dissertation from $2004 .^{3}$ It presents a brief analysis of all the piano works of Penalva available in that year. A frustration at that time was receiving notice that a previously unknown set of Bagatelas ${ }^{4}$ by Penalva would not be available due to inventory issues. Sixteen years later, I have finally received these manuscripts from the "Espaço Penalva" in the city of

\footnotetext{
2 "A Obra Pianística do Padre José de Almeida Penalva". Fregoneze, Carmen Célia, Porto Alegre, 1992.

3 "Um panorama da obra pianística do Padre José Penalva com ênfase na interpretação da Sonata n. 1", Moreira, Heron A.. Escola de música da UFRJ, Rio de Janeiro, 2004.

4 "Um olhar sobre a música de José Penalva, Prosser, Elisabeth. Curitiba, Champagnat, 2000, p. 40.
} 
Curitiba. Thus, they can finally be listed among Penalva's pianistic works; photocopies of the manuscripts appear below as Appendix 4.

The last academic work about this topic we have seen so far in Brazil or abroad is Alexandre Gonçalves' master's dissertation (2009). ${ }^{5}$ It discusses Penalva's three piano sonatas, offering a detailed analysis of each one. Although of course we agree about the large divisions within each movement, my analysis differs in many significant ways from his.

A collection of Penalva's piano and organ works was released in 2011 by the Brazilian professor M. Dottori, ${ }^{6}$ presenting a digitized version of the main keyboard works. This edition will be referred to throughout this project, while also being aware of many controversial points of scoring in the manuscripts and currently published editions.

Although not specifically about Penalva's pianistic repertoire, the catalogue and commentary by Elizabeth Prosser, "Um olhar sobre a música de José Penalva"7 (An Outlook Over José Penalva's Music) provides an indispensable source to be consulted. It presents an overview of Penalva's output, including the pianistic repertoire, as well as a short but rich explanation about his academic and religious trajectory. The catalogue also offers detailed information from those who lived closely with the composer.

Additional academic works such as the dissertation by Grasieli Santos ${ }^{8}$ and the book by Bojanoski and Prosser ${ }^{9}$ are valuable sources for consultation. Although not only

\footnotetext{
5 "As 3 Sonatas para Piano de José Penalva: uma abordagem analítico-interpretativa. "Gonçalves, Alexandre. Florianópolis, 2009.

6 “José Penalva: música solo para piano e órgão", Dottori, Maurício. Curitiba, Antigoa Typographia /

Fundação Cultural de Curitiba, 2011.

${ }^{7}$ Prosser, 2000.

${ }^{8}$ Santos, Grasieli Cristina dos. "As Canções Para Voz E Piano De José Penalva: Um Estudo Crítico-Interpretativo." Curitiba, 2012.

${ }^{9}$ Bojanoski, S. e Prosser, E. S. José Penalva: Uma vida com a batina e a batuta. Curitiba: Artes Gráficas e Editora Unificado, 2006.
} 
about Penalva's piano repertoire, they have intersectional points with the topic. Thus, all cited sources considered, comprehensive bibliographic materials related to Penalva's music and life support this research. 


\section{Chapter One}

\section{José Penalva (1924-2002): Life and Work}

José de Almeida Penalva was born on May 15, 1924, in the city of Campinas, which lies within Brazil's state named São Paulo. He was active in many roles throughout his life: composer, priest, professor, musicologist, critic, conductor, and writer. From a very religious family, he received music training from an early age under his parents' guidance. His mother played the piano and sang, and his father played the guitar. Young José took his first piano lessons with his mother at the age of four; unfortunately, these lessons were tragically interrupted by his mother's death two years later, when he was only six years old.

When he was 11, Penalva enrolled in "Ginásio dos Claretianos" (Claretiano Middle School) in the city of Rio Claro, SP, later being assigned to be a conductor of this institution's choir when he was only 14 . This Brazilian branch of an originally Spanish educational institution would be more than just a religious influence in Penalva's life. At this point he had already been strongly influenced by the modal compositional style of Father Luíz Iruarrizaga (1891-1928), who was recognized by Manuel de Falla as one of the best European sacred-music composers at the beginning of the 20th century.

In 1941, after a year at Claretianos' Novitiate headquarters, he moved to Curitiba city, Paraná state. There he studied philosophy and theology at what was then called "Seminário Maior dos Claretianos" (Claretianos' Major Seminary). In 1941, he established the vocal ensemble "Seminarists' Schola Cantorum Aloysiana" and would 
spend the rest of his life solidifying an important career as priest and musician in the city of Curitiba.

Later on, from 1945 to 1949 , still as a seminarian, Penalva founded the magazine "Vida Claretiana" (Claretiano Life), writing theological articles. He also conducted the choir "Orfeão Claretiano" (Choral Society of Claretiano). From this time came his first liturgical and secular pieces, later cited in his output catalog as youthful composition exercises.

At the end of 1949 he was ordained as a priest. During the next two years, 1950-1952, he was transferred to Guarulhos, SP, working at "Instituto de Filosofia Claretiano" (Claretiano Philosophy Institute) as professor and conductor. There he taught philosophy and music as well as conducting both the Parochial and Institute choirs.

In 1952 he moved back to Curitiba City, PR, joining the newly created "Studium Theologicum" (Theology College), nowadays affiliated with the "Pontifícia Universidade do Paraná" (Paraná Catholic Pontifical University), where he worked as professor of theology and music; he also served as conductor and capellmeister of the church "Imaculado Coração de Maria" (Pure Heart of Mary).

The years 1950-58 were very productive for the composer: he studied harmony and counterpoint and fugue under Savino de Benedictis in São Paulo City, SP (1950-56); in 1956 he earned his master's degree in theology from the "Faculdade Nossa Senhora da Assunção" (Our Lady of the Assumption Theology College); and in 1956-58, he studied in Rome, Italy, at the "Universidade Gregoriana" (Gregorian College), completing his doctorate in theology in 1958. Also during this period in Rome, 
he completed specialized courses in Renaissance Music (under Domenico Bartolucci), and in Gregorian Chant (under Rafaelle Baratta), at "Pontifício Instituto de Música Sacra" (Pontifical Institute of Sacred Music).

From 1958 to 1960, he specialized in contemporary music under Damiano Cozzella in São Paulo City, where he was in contact with new avant-garde techniques of that time, newly brought from Europe by his professor. In 1959, Penalva accepted a position as professor at "Escola de Música e Belas Artes do Paraná" (Paraná Music and Fine Arts School / EMBAP), teaching counterpoint and fugue there until the 1980's.

Penalva was also very active outside the magistery. He was founder and president of "Sociedade Pró-Música de Curitiba" (Curitiba Pro-Music Society) in 1963. He was also president of the "Comissão de Música Sacra do Congresso Eucarístico" (Eucharistic Music Congress Committee), producing eight dissertations on varied topics in liturgical music.

In 1968, he took part in the "Movimento de Renovação da Música Sacra" (Movement for the Renewal of Sacred Music), bringing together many important Brazilian composers such as Osvaldo Lacerda, Ernst Widmer, Edino Krieger, Lindemberg Cardoso and Henrique Morozowicz. Some of the repertoire generated at the event was published by "Irmãos Vitale"; other pieces remain unpublished even now. From 1971 to 1976 , he published several works of music criticism for the Curitiba and Campinas journals, under the alias "Affonso Vilhena."

Penalva was highly active as a musical promoter, organizing many musical events in his state. He was organizer and faculty member for many issues of "Festivais de Música do Paraná" (Paraná Music Festivals), from 1965 to 1977. 
Despite using many modern compositional techniques in his output, Penalva was always connected to his own folk roots, for example serving as a member of the Paranaense Folklore Committee from 1968 to 1972. Around 1970, the Church's renewal of his preferred music styles was overcome by popular-music songs. At that point, Penalva moved away from sacred-music composition, turning toward instrumental and orchestral music. He also abandoned tonality, adopting techniques such as atonalism, serialism, and randomness, among other avant-garde musical procedures.

He also played an important role in Brazilian musicology. From 1971 to 1990, he was member and vice-president of "Sociedade Brasileira de Musicologia" (Brazilian Musicological Society), also serving as one of its advisors. His essays about the musical collection of the "Arquivo Eclesiástico de Mariana" (Mariana City Ecclesiastic Archive), were recognized by the important Brazilian musicologist Paulo Castagna as a significant contribution about musicological methods, motivating a discussion in this area which has continued to evolve in Brazil since the end of the 20th century.

Penalva returned to Rome in 1972-1973, for a theological review. He also completed what was tantamount to a composition master's degree, a free composition course devised at that time by Professor Boris Porena (one of the greatest avant-garde Italian masters of the time) at Santa Cecilia Conservatory. In 1972, along with other important composers from the time (including John Cage, Luciano Berio, and Pierre Boulez), Penalva attended an event in Rome at which, as he later explained, the participants concluded that much of the music composed since the 1950's reveals a hermetic quality that has been a decisive factor in its low public acceptance. 
In 1982, the composer established one of the most important Brazilian choirs, the internationally recognized "Madrigal Vocale," which Penalva conducted until his last years. Bruno Spadoni, his assistant, took up the choir activities after Penalva's death, leading this choir until the current time.

Penalva's book about the Brazilian composer Carlos Gomes ("Carlos Gomes - o compositor") was awarded the "Prêmio Funarte" (Funarte Prize) in 1986.

After two more trips to Italy, at the invitation of a music festival and also as a Goethe Institut scholarship student, Penalva returned to Curitiba city, PR, where he spent the rest of his life. Father José de Almeida Penalva passed away on October 20, 2002, in Curitiba city, Paraná state, Brazil. ${ }^{10}$

\footnotetext{
${ }^{10}$ Bibliographical summary compiled from these sources: "José Penalva: uma vida com a batina e a batuta”, Bojanoski, Silvana e Prosser, Elizabeth S.. Unificado editora, Curitiba, 2006; Gonçalves, Alexandre. "As 3 Sonatas para piano de José Penalva: uma abordagem analítico-interpretativa," 2009; Santos, Grasieli Cristina dos. "As Canções Para Voz e Piano de José Penalva: um estudo crítico-interpretativo." Scribd, 2012; "Um olhar sobre a música de José Penalva", Prosser, Elisabeth. Curitiba, Champagnat, 2000.
} 


\section{Chapter Two}

\section{Musical Output}

\subsection{General Works}

Penalva's output embraces liturgical and secular works for varied instruments, ensembles, and orchestra. The main catalogue of his output was compiled by Elizabeth Serafim Prosser, the most important Brazilian researcher on Penalva: "Um olhar sobre a música de José Penalva: catálogo comentado" (Curitiba: Champagnat, 2000). This catalogue presents the composer's output, divided into two general categories with related subsections, as follows:

1. A música instrumental (instrumental music): instrumento solo (solo instrument); música de câmara (chamber music); orquestra (orchestra).

2. A música vocal (vocal music): voz e instrumento sacro (voice and instrument liturgical); voz e instrumento secular (voice and instrument secular); voz, povo e instrumento sacro (voice, community and instrument liturgical); coro a cappella sacro (choir a cappella liturgical); coro a cappella secular (choir a cappella secular); coro e instrumento sacro (choir and instrument liturgical); coro e instrumento secular (choir and instrument secular); solistas, coro e orquestra (soloists, choir and orchestra) (Prosser, 2000, p. 11).

Starting with the instrumental solo music, we have 21 works for such instruments as organ, piano, and four-hands piano (Prosser, pp. 29-40). Chamber music includes varied ensembles like clarinet and piano; trumpet and organ; oboe and piano; oboe, clarinet and bassoon; and string quartets, among other combinations. The chamber-music output contains ten pieces (Prosser, pp. 43-60). For "voice and instrument liturgical" we have 24 pieces, mostly accompanied by organ (Prosser, pp. 65-80). "Voice, community and instrument liturgical" offers 19 pieces, also with organ 
accompaniment (Prosser, 2000, pp. 83-95). "Choir a cappella" provides 66 pieces (Prosser, pp. 99-126) and "Choir secular" lists 85 pieces (Prosser, pp. 129-169). The "Choir and instrument liturgical" section has 23 pieces and there are 17 in "choir and instrument secular."

Prosser's catalogue also provides a list of the works within each of the mentioned sections (Prosser, 2000, pp. 269-281) as well as in alphabetical order (Prosser, pp. 282-287).

\subsection{Piano Repertoire}

\subsubsection{General Considerations}

Penalva considered his pre-1960's pieces to be compositional exercises. His first solo-instrument pieces were intended for the organ with exception of "Fuguetta" (1956), later incorporated in "Nova et Vetera" (1990) (Prosser, 2000, p. 234). The piano appears before that in just two chamber-music pieces from 1955, as an optional instrument, as shown in Prosser’s catalog: "Doce Coração" (Sweet Heart) (Curitiba, 1955) and "Fita Azul" (Blue Ribbon) (Curitiba, 1955) (Prosser, 2000, pp. 70-71).

Although Penalva's piano pieces comprise a relatively small portion of his overall output, which extensively favors vocal and liturgical works over instrumental ones, ${ }^{11}$ they are quite representative stylistically within his entire musical output.

By 2000, Prosser's commented catalog listed 14 piano pieces; at that time, the Bagatela I (1999) was considered the last one. According to Prosser, this bagatela had

\footnotetext{
${ }^{11}$ Santos, Grasieli Cristina dos. "As Canções Para Voz E Piano De José Penalva: Um Estudo Crítico-Interpretativo." Curitiba, 2012, p. 14.
} 
been the last of a series of bagatelas by Penalva, still in the process of composition and, for this reason, not yet available (Prosser, 2000, p. 40). After an exhausting endeavor, in 2020 I finally received the manuscripts for five previously unknown bagatelas, thanks to Father Jaime Sanchez Bosch, the person in charge of "Espaço Penalva" in Curitiba city (Paraná state, Brazil).

With the addition of those bagatelas, we have now a total of 19 piano works by Penalva, as shown in Figure 1: 


\begin{tabular}{|c|c|}
\hline 1. Sonata no. 2 & 1960 \\
\hline 2. 0 cuco & 1961 \\
\hline 3. Três Versetos & 1963 \\
\hline 4. Mini-Suíte no. 1 & 1968 \\
\hline 5. Mini-Suíte no. 2 & 1969 \\
\hline 6. Sonata no. 1 & 1970 \\
\hline 7. Mini-Suíte no. 3 & 1971 \\
\hline 8. Marcas I (1972) & 1972 \\
\hline 9. Diálogo & 1973 \\
\hline 10. Ponteio & 1990 \\
\hline 11. Nova et Vetera & 1990 \\
\hline 12. Sonata no. 3 & 1991 \\
\hline 13. Toccata & 1998 \\
\hline 14. Bagatela I & $1999^{12}$ \\
\hline 15. Bagatela II & 1999 (outline) \\
\hline 16. Bagatela III & 1999 (outline) \\
\hline 17. Bagatela IV & 1999 \\
\hline 18. Bagatela V & 2000 (outline) \\
\hline 19. Bagatela VI & 2000 (outline) \\
\hline
\end{tabular}

Figure 1: Piano works by Penalva.

${ }^{12}$ With the finding of Penalva's other bagatelas, the previous titled Bagatela (1999) is now called Bagatela I (1999), as referenced by Claretiano Library's catalogue, Curitiba, PR - Brazil. 


\subsubsection{Piano Pieces}

Sonata no. 2 (1960)

Penalva's first piano piece (Sonata no. 2, 1960) was considered by the composer as an exercise which he never intended to publish. When it was eventually published, Sonata no. 1 (1970) had already appeared, with the result that the earlier (1960) work became known as Sonata no. 2. Penalva lays out the sonata in classical forms (sonata-allegro, rondo), incorporating influences from Brazilian and foreign composers. Its musical language is free modalism. As traditional in classical sonatas, it contains three contrasting movements. Later in this document, we will be exploring more deeply the compositional traits involved in Sonata no. 2.

\section{O Cuco (1961)}

"O Cuco" (Cuckoo Clock) (1961) is a small piece, just 24 measures long, with an approximate timing of one minute. Its musical language is freely modal and, despite its small dimension, it displays some characteristic compositional traits of Penalva's, including ornamental intervals of fourth and seventh, as well as abrupt tempo and dynamic contrasts. Its language also includes a kind of text-painting, in which some melodic figurations evoke the song of the cuckoo-clock bird.

Três Versetos (1963): I. Muito calmo (very calmly)

II. Livremente (freely)

III. Com precisão (accurately) 
Described by the composer himself as "...small and independent integrated verses," these three little pieces display twelve-tone precepts (Fregoneze, 1992, p. 43). The music and each verse are set up horizontally in the scoring by Roman algorithms. Some repetitions in their rows do not configure a less orthodox employment of the series, as happens for instance in the Waltz, op. 23, no. 5 ("Fünf Klavierstücke, p. 17") by A. Schoenberg, or in the "Quaderno Musicale di Annalibera" (p. 4, 8), by Luigi Dallapiccola (Moreira, 2004, p. 44).

\section{Mini-Suíte no. 1 (1968): I. Introdução (Introduction) \\ II. Ciranda (folk tune) \\ III. Modinha (little song) \\ IV. Valsa (Waltz)}

A very succinct work as well, the "Mini-Suíte no. 1" appears as four small pieces, each of which employs a twelve-tone style. Despite using serial technique, the row's appearance in the second piece, Ciranda, resembles the melodic contour of the famous Brazilian folk tune, "Ciranda, cirandinha." ${ }^{13}$ Fregoneze attributes to Penalva the statement that around this time it was in vogue to compose by mixing folk melodies with twelve-tone technique (Fregoneze, 1992, p. 51). Although a less strict handling of the

${ }^{13} \mathrm{https}: / / w w w . y o u t u b e . c o m / w a t c h ? v=V 8 J U 4 Q 7 h K e 8$. 
rows occurs in Ciranda (starting with the second half of the row instead), all three of the other pieces employ the twelve-tone row in full and follow serial precepts.

Mini-Suíte no. 2 (1969) $)^{14}$ : I. Cana-verde ${ }^{15}$

\author{
II. Ponteio ${ }^{16}$
}

III. Sincopado ${ }^{17}$

Also a short piece, the Mini-Suíte No. 2 is more technically demanding than the previous solo piano works written after Sonata No. 2. The suite is comprised of three movements, in which we see Brazilian folk material mixed with twelve-tone technique. This same blend occurs in other works by Penalva, including Três Versetos and Mini-Suíte No. 1 (Fregoneze, 1992, p. 53). Here, Penalva employs two series, "principal" and "ornamental," as indicated in the scoring. Despite the omission of the first and twelfth pitch classes, we can consider that the twelve-tone precepts of "Desafio" are

\footnotetext{
${ }_{14}$ Although in my previous dissertation (Moreira, 2004, p. 52) as well as in Dottori's album (2011, p. 48) there is a date of composition for this piece of 1968, following Prosser's catalog (2000, p. 33), the manuscript (unavailable to me in 2004) bears the date 1969. Thus, I am officially adopting this date in this research.

${ }^{15}$ Dance originally from Portugal and Spain, a sort of marcas (see also footnote 17), adopted in Brazil within some states like São Paulo, Paraná and Rio Grande do Sul (https://dancasfolcloricas.blogspot.com/2011/03/cana-verde.html).

${ }^{16}$ Related to the Brazilian viola caipira (hillbilly guitar) performance, particularly the way of strumming the guitar and other Brazilian string instruments. This genre was explored for other important Brazilian composers as for instance Camargo Guarnieri's " 50 Ponteios" for solo piano. Orchestral and string works by other composers like Cláudio Santoro and Guerra-Peixe also drew on the ponteio (https://books.google.com.br/books?id=MPLzDAAAQBAJ\&pg=PA116\&lpg=PA116\&dq=Folclore+brasileir o+ponteio\&source=bl\&ots=|4BuaTimQW\&sig=ACfU3U3 HpvLOtivBHfVqV-bvosidYiZQ\&hl=en\&sa=X\&v ed=2ahUKEwihyLTSmKDpAhUCA9QKHQLnB1UQ6AEwCnoECAKQAQ\#v=onepage\&q\&f=false).

${ }_{17}$ According to Mário de Andrade (one of the most important Brazilian musicologists, poets, novelists,and art historians, among other activities), the syncopated rhythm present in so many types of Brazilian music, usually ascribed to African influence, is actually a Portuguese inheritance (https://books.google.com.br/books?id=yKRYksPTT8sC\&pg=PA65\&dq=Folclore+brasileiro+\%22sincopad $0 \% 22 \& h l=e n \& s a=X \& v e d=0 a h U K E w i j i j o T L n K D p A h X r L L k G H W t V B 9 \mid Q 6 A E I V D A F \# v=o n e p a g e \& q=F o l c l o r e$ $\% 20$ brasileiro $\% 20 \% 22$ sincopado $\% 22 \& f=$ false).
} 
generally kept in the overall suite (Moreira, 2004, p. 59). The composer extensively explores his thematic material. For instance, the theme of "Sincopado" elaborates that of "Ponteio" (Moreira, 2004. p. 59, ex. 64), which is later employed as accompaniment, where the right hand utilizes the initial theme of "Ponteio" in parallel chords (p. 60, ex. 65). Penalva also made two arrangements of this piece for piano four hands; both versions appear in Dottori's album (2011, pp. 51-65).

\section{Sonata no. 1 (1970): Seresta e Desafio}

The Sonata No. 1 appears in one movement, despite the two large sections indicated by the composer at the beginning of the piece. These two sections may be thought of as individual movements because of their contrasting characters. The work is composed in classical sonata-allegro form, with traditional main themes, transitions, a development, a recapitulation, and a coda, as one would expect. Within that structure, Penalva uses twelve-tone technique mixed with Brazilian folk material.

\section{Mini-Suíte no. 3 (1971): I. Toc, toc \\ II. Murucututu}

Unlike Penalva's previous suites, the Mini-Suíte no. 3 contains only two contrasting movements. It is also a serial work and, according to the composer's indication on the score, the title, "Toc, toc," suggests the sound of "...the comings and goings of a pony." (Moreira, 2004, p. 69, ex. 81). The scoring is more modern, including 
charts showing musical patterns or the employment of bars between the two staves, giving more interpretive freedom to the performer (Dottori, 2011, pp. 68-69) than is typical. "Murucututu" is a very contrasting piece: Its character indication, Docemente (sweetly) and its thin texture produce an atmosphere completely different from that of

"Tic toc." Here, the composer uses unconventional techniques, like directions to "pluck the string" and unusual rhythmic notation (Dottori, 2011, p. 69).

\section{Marcas I (1972)}

This piece also belongs in Penalva's serial compositional phase. Although structured in a single movement, it is subdivided into four sections according to the character and suggested metronome tempo: I. Triste (sad), quarter=44; II. Brejeiro (malicious), ${ }^{18}$ quarter=96; III. Com calma (calmly), quarter=80; IV. Íntimo (intimate), quarter $=44$.

According to Prosser, Penalva incorporated some of Pananá state's folk tunes into this piece via a non-orthodox twelve tone technique (Prosser, 2000, p. 36). ${ }^{19}$ These folk tunes themselves are also called marcas and have varied traits according to their region of origin. ${ }^{20}$

\footnotetext{
${ }^{18}$ Other possible translations of brejeiro might include "goofy" or "trampy."

19 Penalva had a deep involvement with Paraná state's folklore, writing many academic works about the topic (Prosser, 2000, p. 18).

${ }^{20}$ There are 27 different kinds of marcas in Brazil, and many others according to the region where the fandango* is danced ( ${ }^{*}$ Fandango is a set of many popular dances known as marcas). Over time, the fandango performed in Paraná state was being assimilated by the seaside's country people, acquiring its folklore character. More content about the topic appears at the following site: http://www.educacaofisica.seed.pr.gov.br/modules/conteudo/conteudo.php?conteudo=31).
} 


\section{Diálogo (1973)}

"Diálogo" inaugurates Penalva's atonal pianistic phase.${ }^{21}$ As we see in Dottori's album (2011, p. 82-83), the score looks very modern. There are no bar divisions, but there are many charts, written directions, approximate and pictorial notation, giving quite a lot of freedom to the performer. Penalva also penned these specifications:

Mãos que progressivamente passam de um som sonoro, de ritmo e altura controlados, calmo e íntimo, a outro, quebrado, percussivo, indeterminado e solto, precipitado e expansivo, extinguindo-se depois. ("Hands which progressively go from one sonorous sound of controlled pitch and rhythm, calm and intimate, to another, broken, undetermined and released, precipitous and expansive, extinguishing afterwards.") (Penalva, 1973. Moreira, 2004, p. 81).

Additional observations made by Penalva to Elisabeth Prosser in 1994 can be

found in Prosser's catalog and commentary as follows:

A duração da obra será determinada pela imaginação e criatividade do executante. $\mathrm{Na}$ execução, é fundamental observar que as idéias se desenvolvam e se realizem de forma conveniente. ("The work's timing will be determined by the imagination and creativity of the performer. During the performance, it is essential to notice that the ideas develop and carry themselves out in the most musically efficient and effective way.") (Prosser, 2000, p. 37).

\section{Ponteio (1990)}

Similar to "Diálogo," "Ponteio" is written in a single movement but with many contrasting sections, delineated from each other by fermatas and by different character

\footnotetext{
${ }^{21}$ According to E. Prosser ("José Penalva, O Mestre Da Música” Parte 4), "Diálogo" was also the name of a church project Penalva led for couples, within which he met them weekly for advising sessions.
} 
indications and textures. These sections can be labelled as follows: I. Misterioso

(mysterious) II. Gracioso (charming) III. Lento expressivo (slowly expressive) IV. Veloce (ondular rapidissimamente) - rapid (rippling very fast).

The term, ponteio, comes from Brazilian folklore and is related to the kind of guitar strumming known in the Paraná countryside. Prosser cites the composer's commentary about the piece:

Da realidade do violão, como indica a designação de Ponteio, foi escrita uma peça rapsódica, um balé muito expressivo, enquanto são descritos momentos, lançadas idéias que se repetem mas não se desenvolvem (como muitas vezes fazia Mozart). ("Ponteio designated the piece to originate from the sound of a folk guitar. It was meant to be rhapsodic, a very expressive ballet, where some moments are detailed, while other moments cast ideas which repeat, but are not developed themselves - a technique often used by Mozart.") (Penalva as cited in Prosser, 2000, p. 37).

\section{Nova et Vetera (1990): I. Fuguetta II. Mozartiana III. Preludietto e Fuga}

"Nova et Vetera" is comprised of three pieces separately conceived by the composer at an earlier time: "Fuguetta" (1956), "Mozartiana" (1960), and "Preludietto e Fuga" (1960).

Although it starts as a traditional baroque fughetta, Penalva's "Fuguetta" uses some incidental bitonality later in the work. As stated by the composer "...here, [there is] a virus which erodes the tonality." (Penalva, as cited in Fregoneze, 1992, p. 91). Penalva indicates his "virus" at several spots throughout the piece by using ancient notation.

"Mozartiana" was originally conceived as a sonata in two voices, dedicated to W. A. Mozart. Unfortunately, the final two movements were lost by the composer, and so 
he decided to incorporate other isolated pieces into the "Nova et Vetera." Following the "Preludietto," "Mozartiana" begins as a traditional, classical tonal piece, but many times it is interrupted by modern melodic and harmonic changes. As Penalva suggests, his fugues were inspired by the style of J. S. Bach (Penalva, as cited in Fregoneze, 1992, p. 96).

According to Penalva, the "Preludietto" is conceived without any thematic relationship to the fugue; instead, it reflects free, improvisational style according to the style of many Bach preludes (Fregoneze, 1992, p. 96). The "Fuga" employs some traditional compositional procedures, like the intervallic relationship of a 5th between subject and countersubject. However, unlike Bach, Penalva utilizes some incidental polytonality.

\section{Sonata no. 3 (1991)}

Without a doubt, this is the most technically demanding of Penalva's piano pieces. Like the previous sonatas, it has three contrasting movements; but it is freely atonal and the movements employ classical structures like sonata-allegro and rondo forms. Like Bach, Penalva recycled and reused his own output. New arrangements of the second and third movements of this sonata became "Três momentos" (Three moments) for strings (1990-1993), under the titles “Lied" and "Rondó-Agitato," respectively. More details about this sonata will be provided in Chapter Three. 


\section{Toccata (1998)}

According to the composer's own words, this piece was conceived for electronic media:

"...foi acontecendo espontaneamente ao teclado do computador [...] e [eu precisava] usar a razão para trabalhá-la." ("The piece occurred spontaneously on a computer keyboard and I had to work it out rationally.") (Prosser, 2000, p. 40).

Due to the work's nature, there is no traditional way to score the piece. Some believe that a recording was made by Marcelo Spínola in Campinas (SP), but my attempts to make contact with Spínola have been unsuccessful to date.

\section{Bagatela I (1999)}

The condition of the newly found bagatelas is such that this Bagatela I can still be considered as the last available piano work by Penalva. As stated earlier, it is the first of a series of bagatelas which Penalva intended to compose. ${ }^{22}$ Without the rest of the series, it had been called just bagatela, but now it is called Bagatela I (1999), in order to distinguish it from the newly discovered ones. Bagatela I is written with very modern scoring. This may be the reason it does not appear in any academic work referenced here, apart from my own (ex. 1). ${ }^{23}$

\footnotetext{
${ }^{22}$ Prosser's catalogue (2000, p. 40) mentions the Bagatela I (1999) as being the last of Penalva's bagatelas series; however, according to their compositional dates as well as references in the Claretiano library, it is actually the first one of the series.

${ }^{23}$ Further details can be found in the author's master dissertation (Moreira, 2004, p. 114-116).
} 


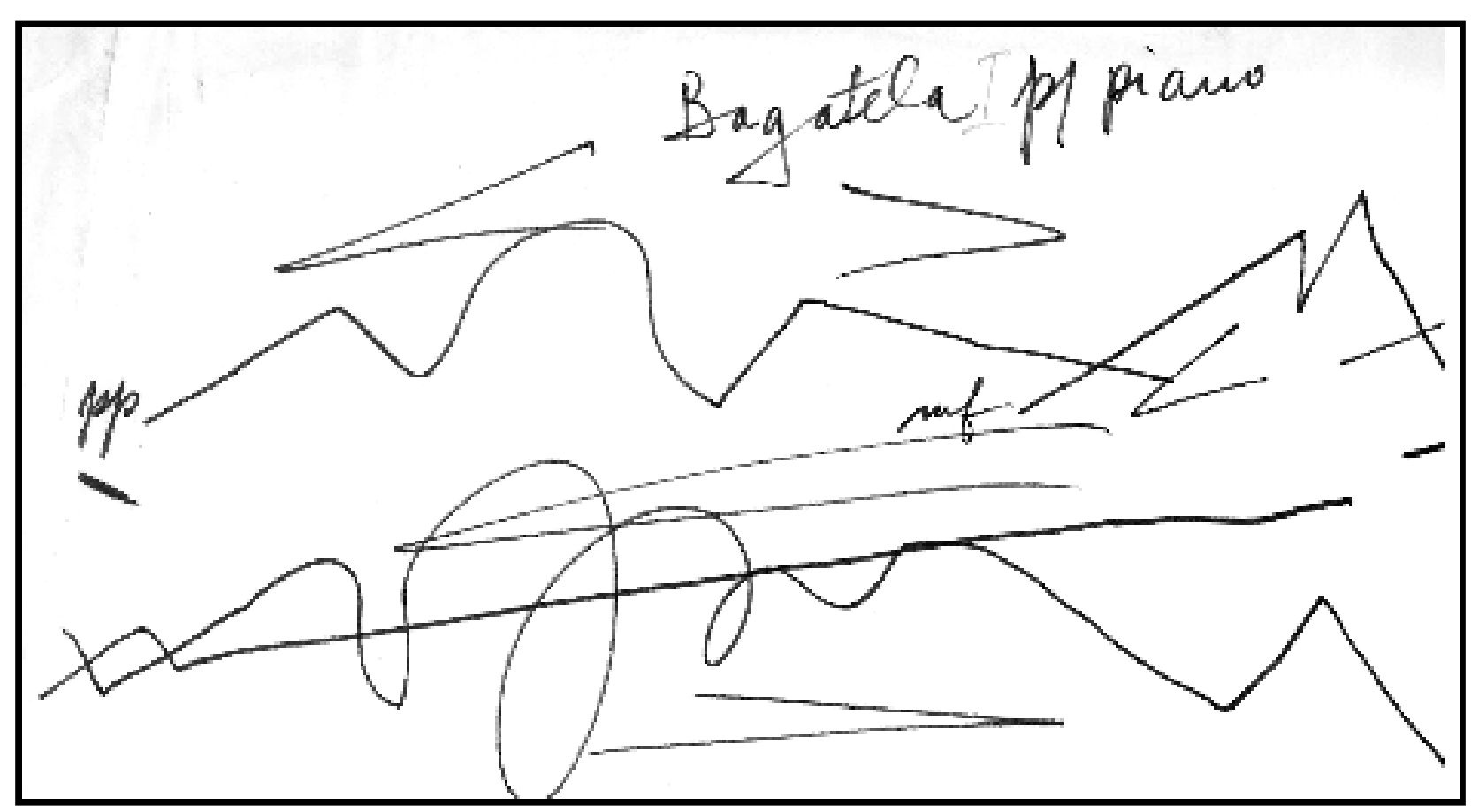

Example 1: Penalva's Bagatela (1999), manuscript (currently, Bagatela I).

\subsection{Bagatelas Series}

It appears that Penalva did not have enough time to complete the task of writing a series of bagatelas. A brief analysis of all of the newfound manuscripts reveals that much of the material is in an unfinished state (see example 2). Among them, obviously apart from the already known Bagatela I (1999), just the Bagatela IV (1999) reveals scoring that potentially could be entirely decoded (example 4); the other ones remain in outline state (example 3). Because the bagatelas' manuscripts are mostly in outline form, including many obvious deletions, it will take some time to produce faithful, digital versions of them. It will also require meticulous and exhaustive research to understand clearly the meaning of the scoring. 
Nevertheless, these manuscripts offer us a clear idea of the compositional style and pianistic writing the composer achieved in his lifetime. We can, for instance, point out some common compositional traits found in these bagatelas which are directly related to Penalva's pianistic idiom: parallelisms, the interval of a 4th in the melodic line, quartal harmonies, clustered textures, tritone intervals, trills as pedal points, modern rhythmic and pitch notation, thin textures, graphic and pictorial notation. 


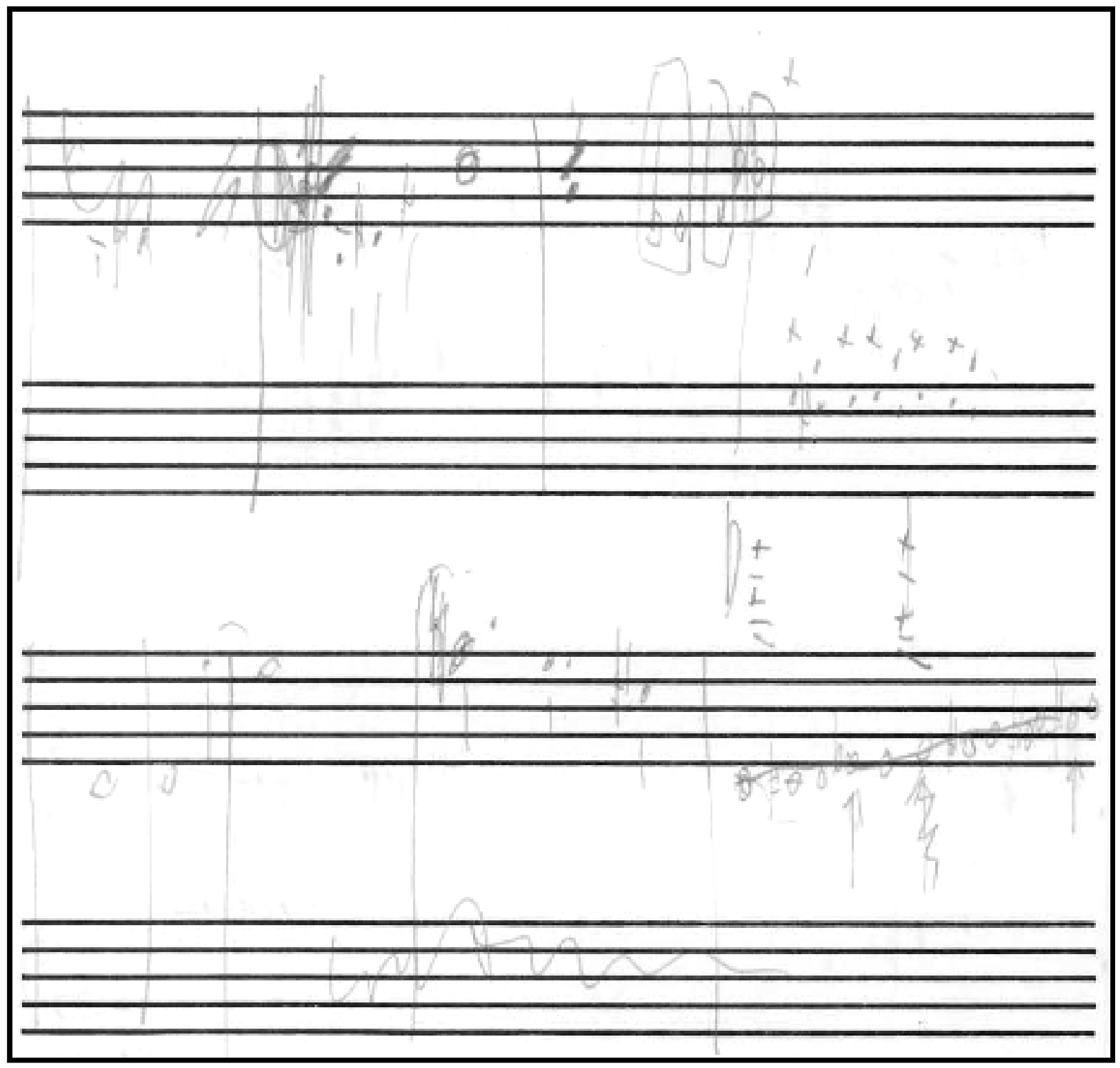

Example 2: Excerpt of Penalva's Bagatela VI (2000), manuscript. 


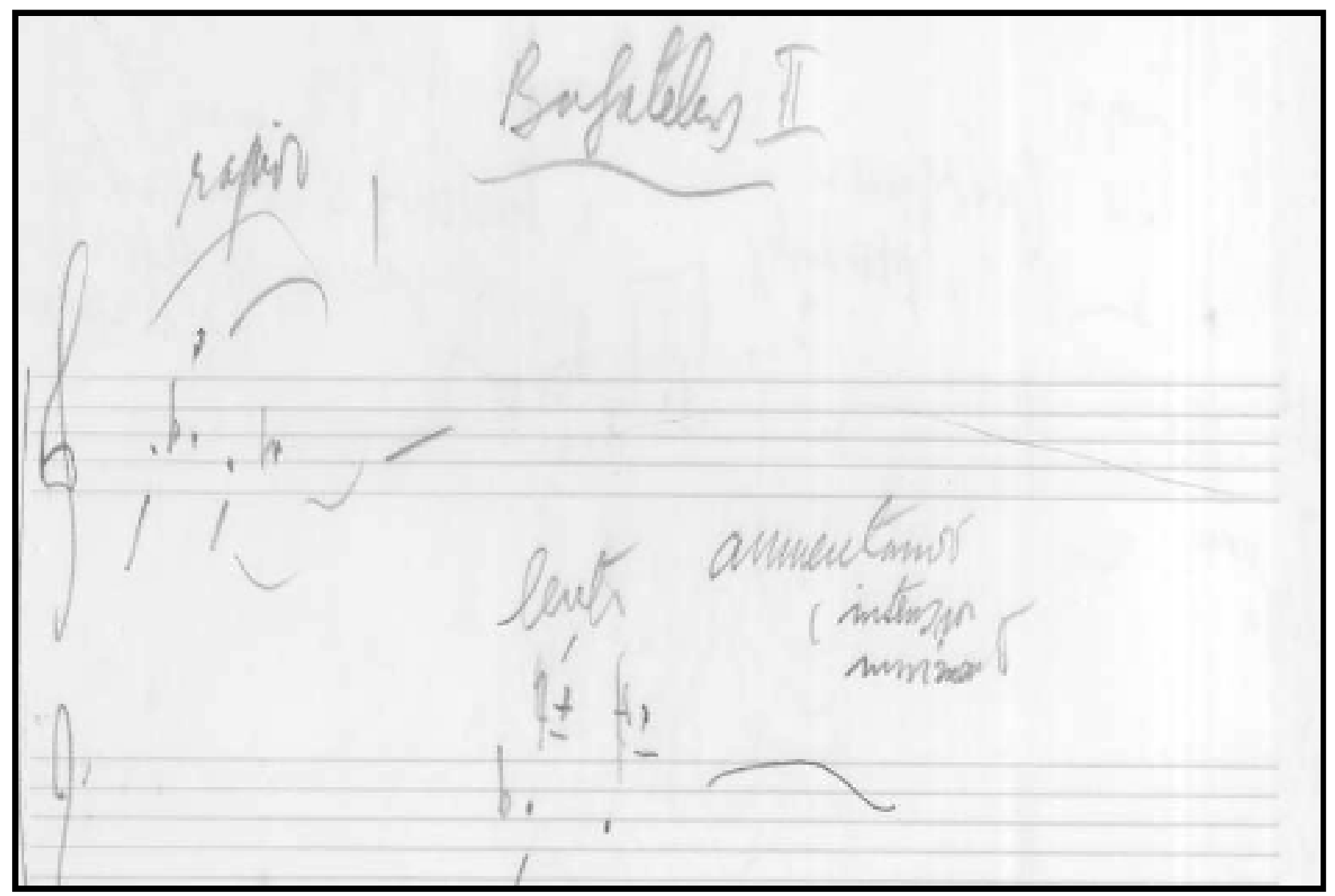

Example 3: Excerpt of Penalva's Bagatela II (1999), manuscript

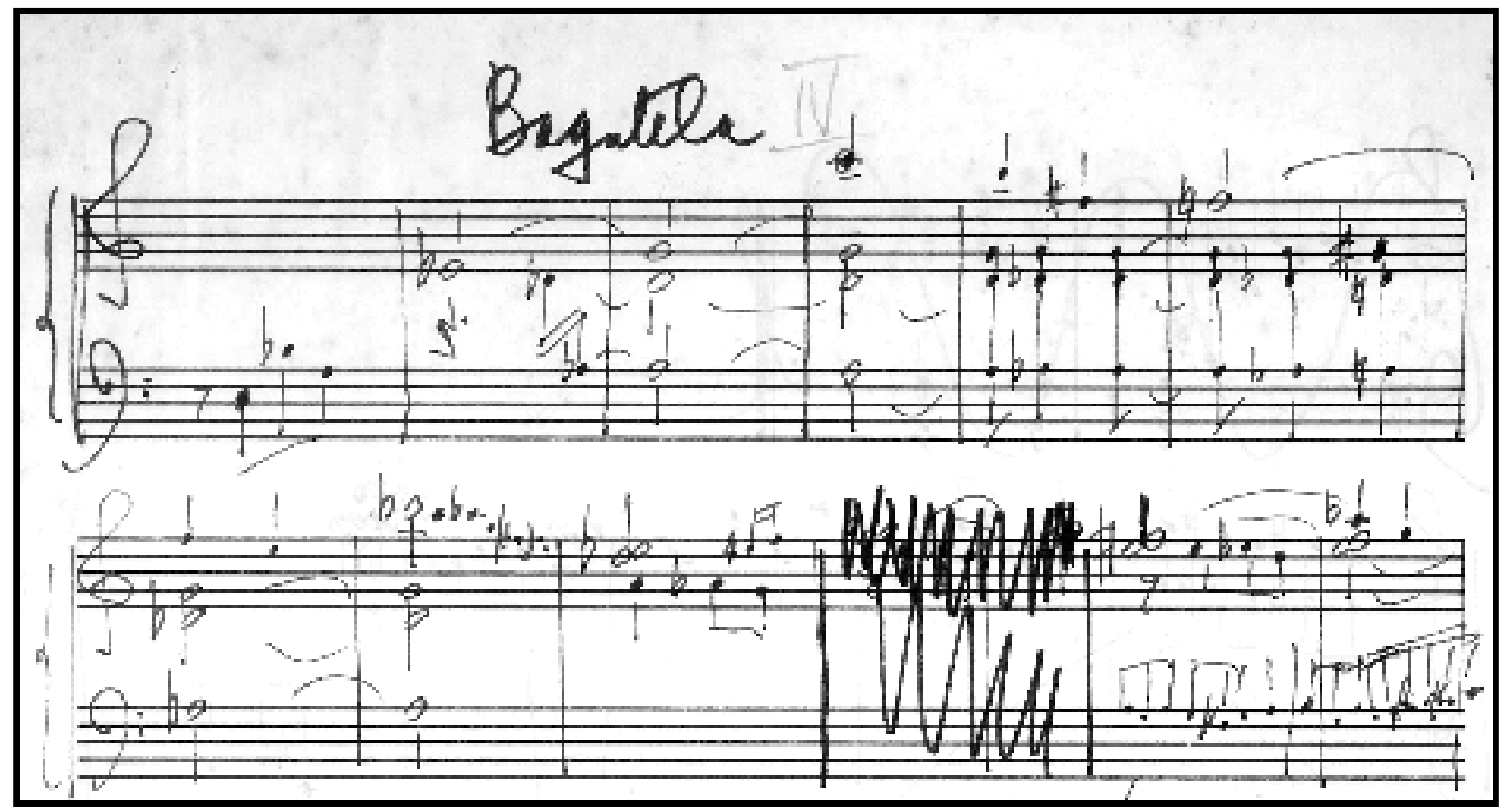

Example 4: Excerpt of Penalva's Bagatela IV (1999), manuscript. 
Here are the newfound bagatelas' bibliographical references, according to the "Espaço Penalva" library's catalogue: ${ }^{24}$

\begin{tabular}{|l|l|l|}
\hline 01-056 & 1999 & BAGATELA I (Curitiba, 1999) Piano. PEN part pen 01-056 \\
\hline $01-057$ & 1999 & $\begin{array}{l}\text { BAGATELA II - Esboço (Curitiba, 1999). No mesmo } \\
\text { manuscrito que Bandeiras de Volpi. Piano. PEN part pen } \\
\text { 01-057 }\end{array}$ \\
\hline $01-058$ & 1999 & $\begin{array}{l}\text { BAGATELA III - Esboço (Curitiba 1999) Piano. PEN part } \\
\text { pen 01-058 }\end{array}$ \\
\hline $01-059$ & 1999 & $\begin{array}{l}\text { BAGATELA IV (Curitiba, 1999) Piano. PEN part pen } \\
\text { 01-059 }\end{array}$ \\
\hline $01-060$ & 2000 & $\begin{array}{l}\text { BAGATELA VI- Esboço (Curitiba, ca. 2000) Piano.PEN } \\
\text { part pen 01-061 }\end{array}$ \\
\hline
\end{tabular}

Figure 2: Bagatelas for piano by Penalva.

${ }^{24}$ The complete manuscripts for these unpublished bagatelas appear below as Appendix 4 . 


\section{Chapter Three}

\section{The Piano Sonatas}

Penalva composed just three solo piano sonatas during his lifetime. They were conceived across large gaps of time, with decades separating the first from the last: "Sonata no. 1" (1970); ${ }^{25}$ "Sonata no. 2 (1960); ${ }^{26}$ and "Sonata no. 3" (1991). ${ }^{27}$ As Fregoneze explains, wide spans of time between conception led to each sonata having a unique style, each being representative of the composer's main musical phases (1992, p. 134). ${ }^{28}$ Fregoneze adds Penalva's words: “...the justification of the Sonatas is the moment I wrote them." (Penalva, according to Fregoneze, 1992, p.134).

Regarding the actual score notation of the sonatas, I decided in most cases to follow the printed scores. This is due to many intricate differences between manuscripts and editions. For example, the manuscript of Sonata No.1 differs greatly from the Ricordi edition (1972), the latter being a version authorized by the composer. To my knowledge, no better primary source for Sonata No. 1 exists. For reasons of historical context and other related issues, I based my analysis of Sonata No. 1 on Ricordi's edition instead of the manuscript.

\footnotetext{
${ }^{25}$ Ricordi brasileira, 1972.

26 “José Penalva: música solo para piano e órgão", Dottori, Maurício. Antigoa Typographia;Fundação Cultural de Curitiba, Curitiba, 2011.

28 “A Obra Pianística do Padre José Penalva”, Fregoneze, Carmen L.. Porto Alegre, 1992.
} 


\section{Analysis}

\subsection{Sonata no. 1 (1970)}

This is the only serial piano sonata by José Penalva and it is written in a single movement. Nevertheless, the marking, "Seresta e Desafio"29 (serenade and challenge), at the very beginning, enhanced by the indication "galhofeiro" 30 (mischievous) in measure 85 , suggests an internal subdivision, splitting the sonata into two main sections, the Seresta and the Desafio.

\section{Seresta}

Exposition: (mm. 1-22)

A1 (mm. 1-5) A2 (mm. 6-8) A3 (mm. 9-14) B1 (mm. 15-18) B2 (mm. 19-22)

Transition: (mm. 22-33)

Development: (mm. 34-67)

D1 (mm. 34-53) D2 (mm. 54-63)

Transition: (mm. 64-67)

Recapitulation: (mm. 68-79)

A (mm. 68-70) B (mm. 71-75) A3' (mm. 75-79)

Coda: (mm. 80-84)

${ }^{29}$ Desafio is a Brazilian popular genre in which two singers "challenge" each other by improvising mocking lyrics on the spot.

${ }^{30}$ Although pointed out later on in measure 85 , this character indication "galhofeiro" is intrinsically related to the Brazilian popular genre "Desafio," indicated at the very beginning of the scoring. 
As in the other piano sonatas by Penalva, the first section, Seresta (mm. 1-84), formally follows a classical sonata-allegro model. It is a twelve-tone serial piece, as well; thus, it is structured by predetermined rows.

As might be expected, theme $\mathbf{A}$ is composed using the row Oo (original zero), as follows:

Oo: $0-11-8-7-10-6-5-9-3-1-4-2$

Oo: D-C\#-Bb-A-C-Ab-G-B-F-Eb-F\#-E

Theme $\mathbf{A}$ has a lyrical and expressive character and is presented three times during the exposition. At the very beginning, it is set as a single melodic line with no accompaniment, where three repetitions of the pitch classes 4-1-3 appear before the last one "Fb" (or "E") (ex. 1, mm. 1-5).

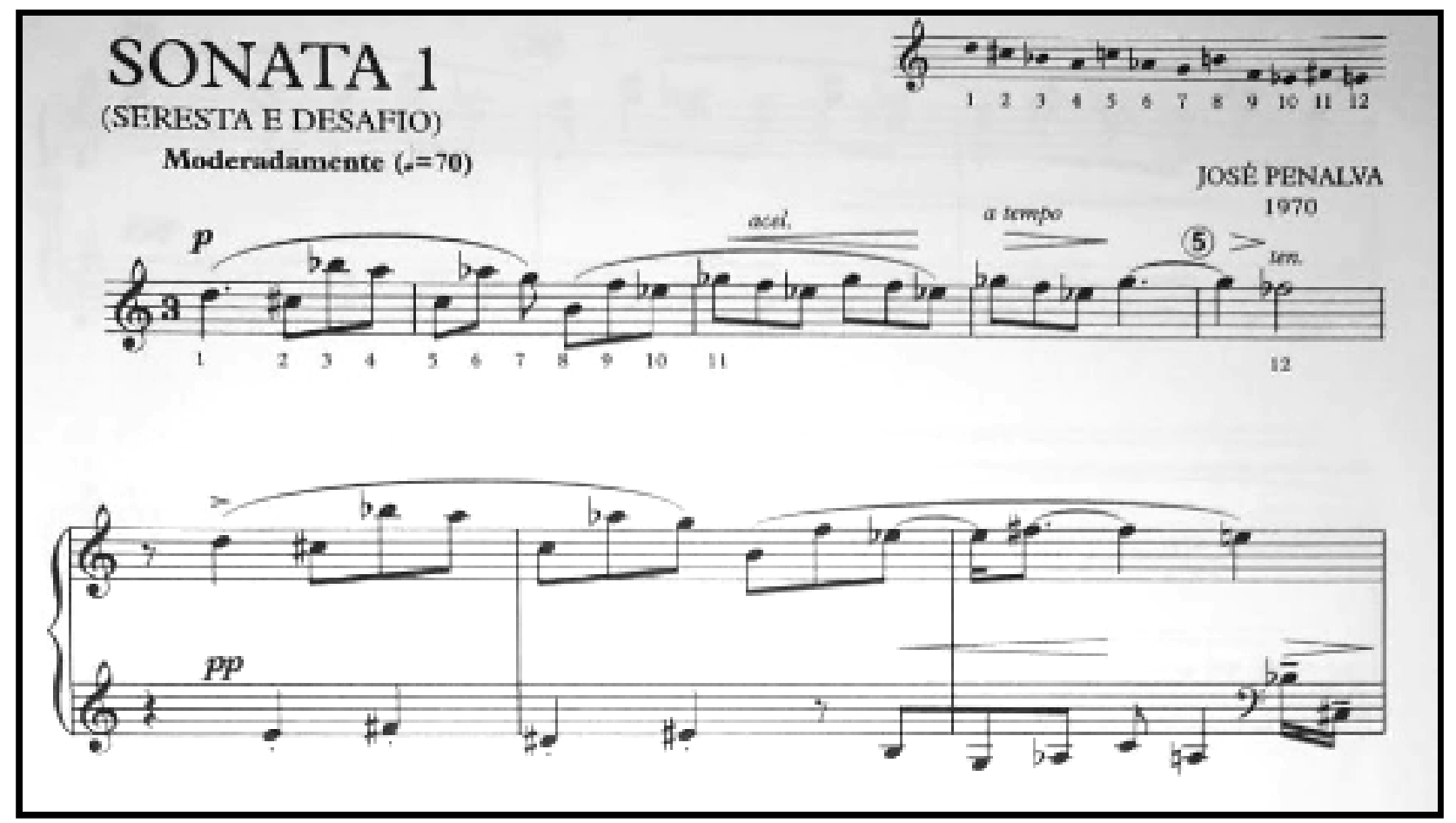

Example 1: Penalva's Piano Sonata no. 1 (1970). H. A. Moreira's version (2020), mm. 1-8. 
The second presentation of theme $\mathbf{A},(\mathbf{A} 2)$, employs the same melodic line with slightly modified rhythm, accompanied by a contrapuntal lower melodic line (ex. $2, \mathrm{~mm}$. 6-8). The contrapuntal accompaniment in the left hand employs the retrograde of the original (ROo) (ex. 2, mm. 6-9). Note that its last three pitch classes (Bb-C\#-D) are used as part of the new, third, presentation of theme A, (A3) (ex. 2, m. 8-9).

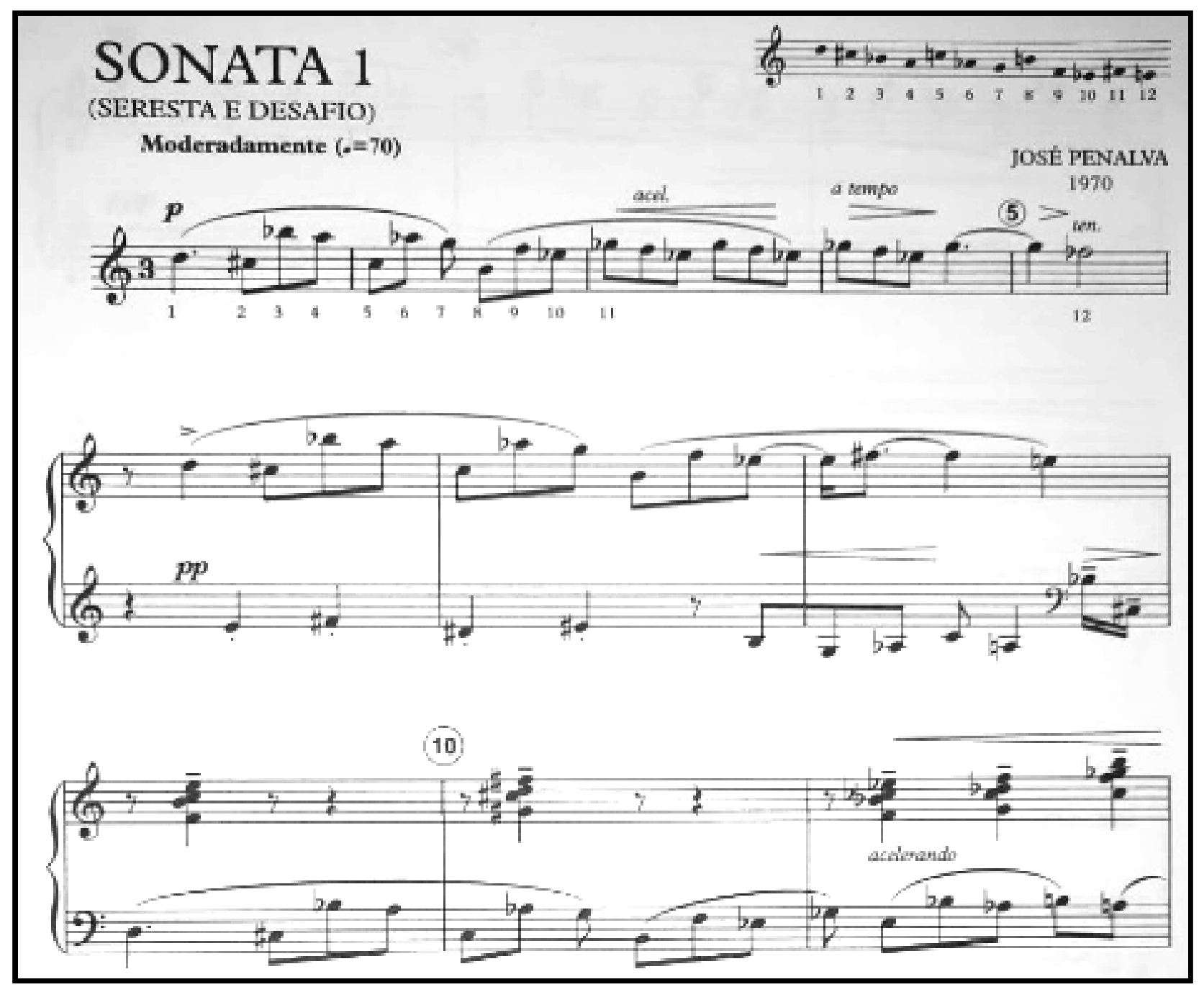

Example 2: Penalva's Piano Sonata no. 1 (1970). H. A. Moreira's version (2020), mm. 1-11.

A3's presentation also uses the original zero row (Oo), this time in the bass line, and accompanied by chords made of 2 nds and 4 ths in the right hand (ex. 3, mm. 8-14). 
In the right hand, the chord's top voices outline the ROo, with repetitions of its last pitch classes, A-Bb, in the chord's lower voice, and of C\#-D in the chord's top voice (ex. 3, mm. 13-14).

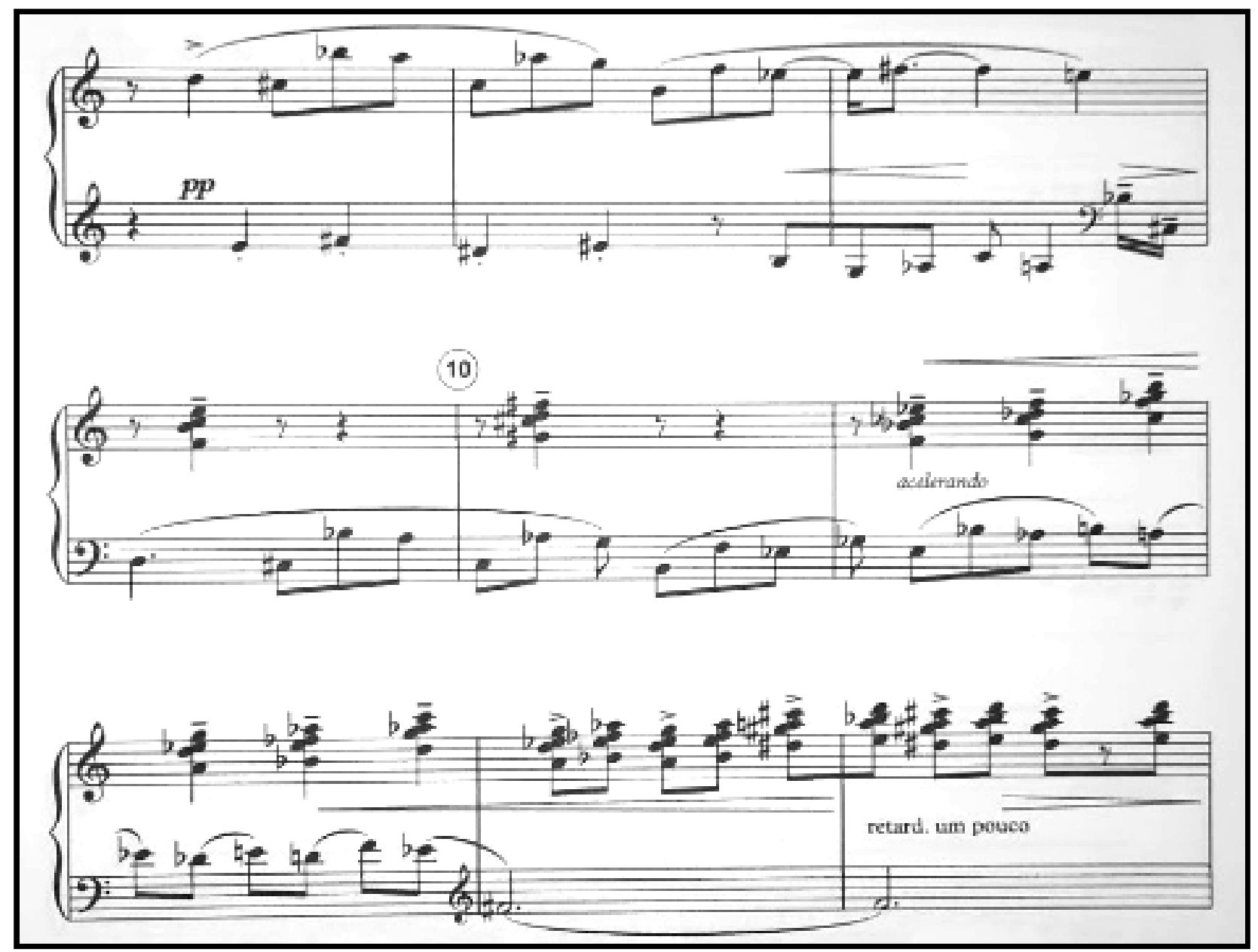

Example 3: Penalva's Piano Sonata no. 1 (1970). H. A. Moreira's version (2020), mm. 8-14.

Theme $\mathbf{B}$ theme also has an intimate and expressive character. But, unlike theme $\mathbf{A}$, it presents a melodic descent (ex. 4a/4b, mm. 15-22). It is built from $\mathrm{O5}$ (original five) but without pitch class 6 (Ab). Fregoneze (1992) and Gonçalves (2009, p. 59) consider this second theme to be non-serial. However, my opinion is different. I argue that in 1970 when this sonata was composed, the twelve-tone technique had already been extensively studied and employed by many composers, including many 
Brazilian ones, in addition to Schoenberg and his disciples, Berg and Webern. ${ }^{31}$ Thus, I suggest that certain compositional liberties with repetitions and pitch-class omissions were acceptable at this time, and not enough to constitute a non-orthodox procedure. This is my opinion in the case of this sonata's B theme.

Penalva's $\mathbf{B}$ theme is presented twice in varied textures. First, a single melodic line appears in the right hand, accompanied by harmonic 2nds (ex. 4a, 15-18). Afterwards, its melodic line is ornamented by perfect 4 ths, and accompanied by a melodic chromatic bass line created by elaborating material from ROo (ex. $4 \mathrm{~b}, \mathrm{~mm}$. 19-22).

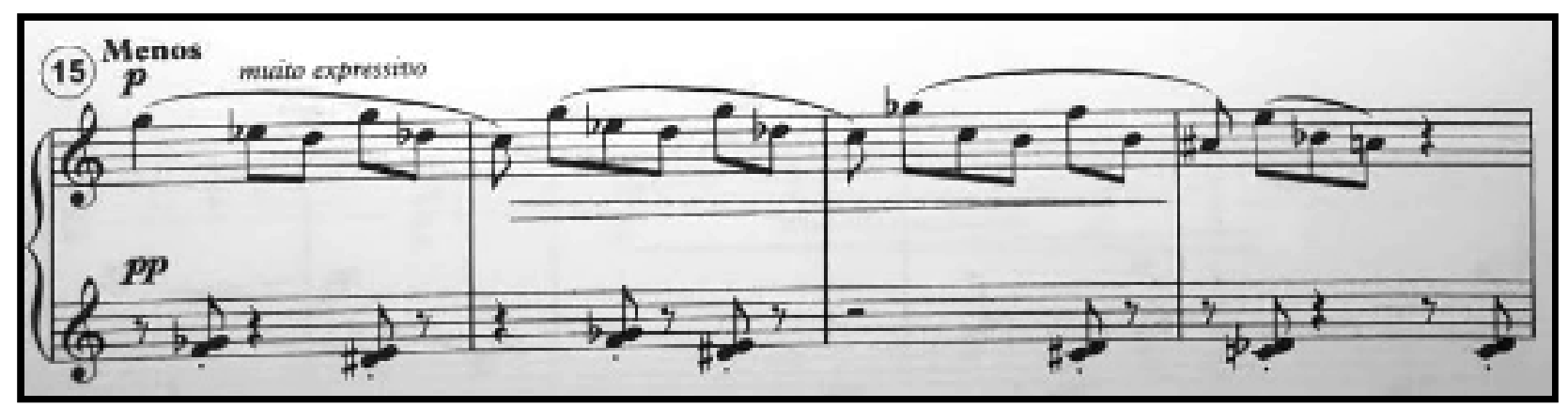

Example 4a: Penalva's Piano Sonata no. 1 (1970). H. A. Moreira's version (2020), mm. 15-18.

\footnotetext{
31 Twelve-tone technique was introduced in Brazil by the German composer Hans Joachim Koellreutter in the 1940's.
} 


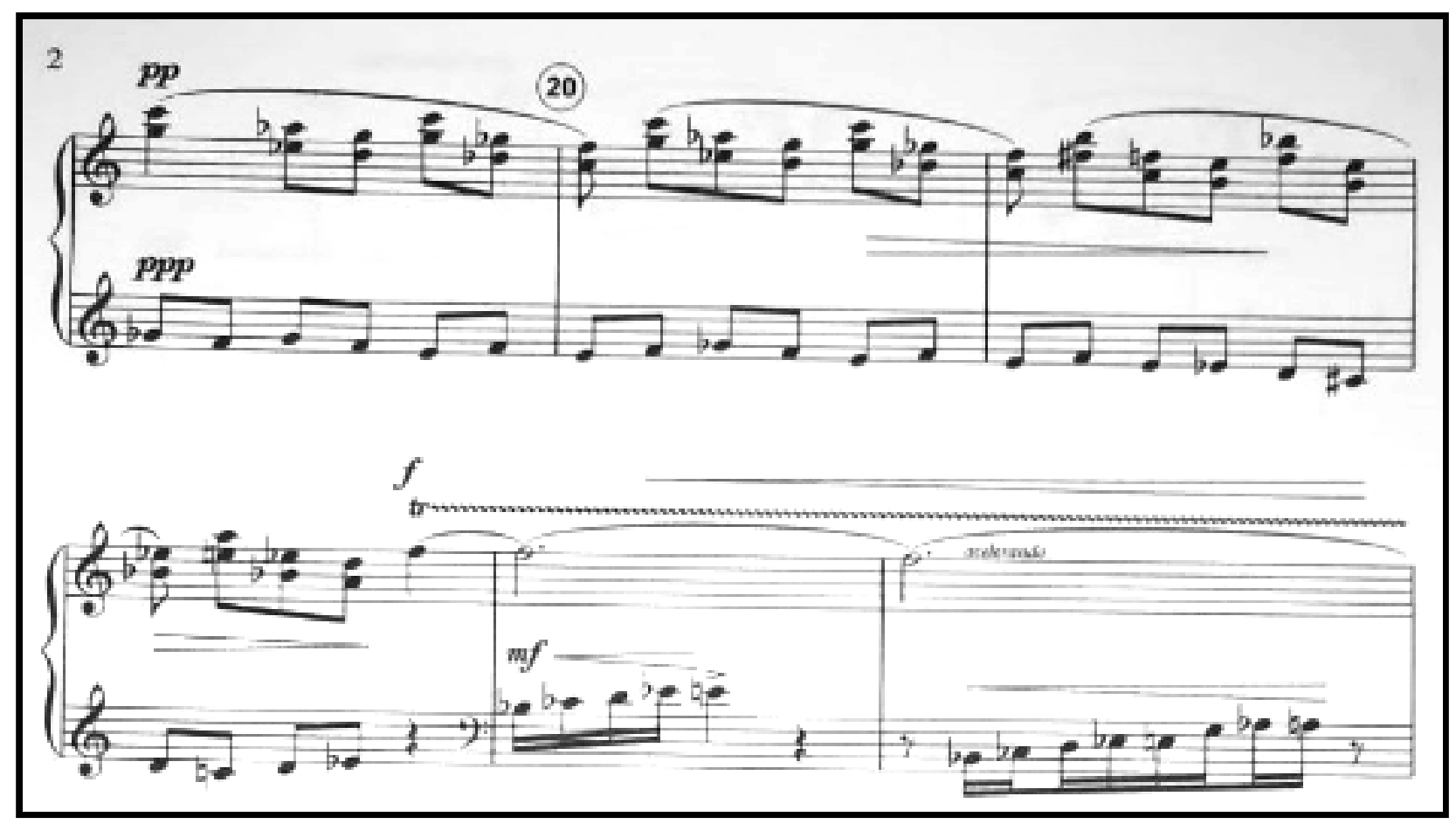

Example 4b: Penalva's Piano Sonata no. 1 (1970). H. A. Moreira's version (2020), mm. 19-24.

After the exposition, there is a contrasting transition ( $\mathrm{mm} .22-33)$ leading to the development. The transition can be also divided into two parts according to its different textures: T1 (mm. 23-29) and T2 (mm. 30-33).

Part one of the transition, T1, (mm. 23-29) starts with anacrusis into measure 23 (ex. $4 \mathrm{~b})$, along with an abrupt dynamic change. The employment of a forte trill in the uppermost voice immediately follows the mysterious and intimate atmosphere of the exposition's quiet theme B ( $p p$ and ppp), generating a huge contrast (ex. 4b, m. 22-23).

The contrasting passage starts with two ascending motives presented by the left hand (ex. 5, mm. 23-24), leading to lengthier and rhythmically faster ascending and descending scales ${ }^{32}$ accompanied by trills in the right hand (ex. 5, mm. 25-28). These scales are built from inversion 8 ( $\mathbf{1 8}$ ) and $\mathbf{I 2}$ (ascending), and from 08 and $\mathbf{0 2}$

32 In the manuscript (1970), there is the indication "muito ruído" (very noisy) for these scales (mm. 25-26), which does not appear in Ricordi's edition (1972). 
(descending), respectively. The right hand trills $(\mathrm{mm} .26,28)$ each end with a melodic termination (F-Eb-Gb-E) representing the last four pitch classes of Oo (ex. 5).

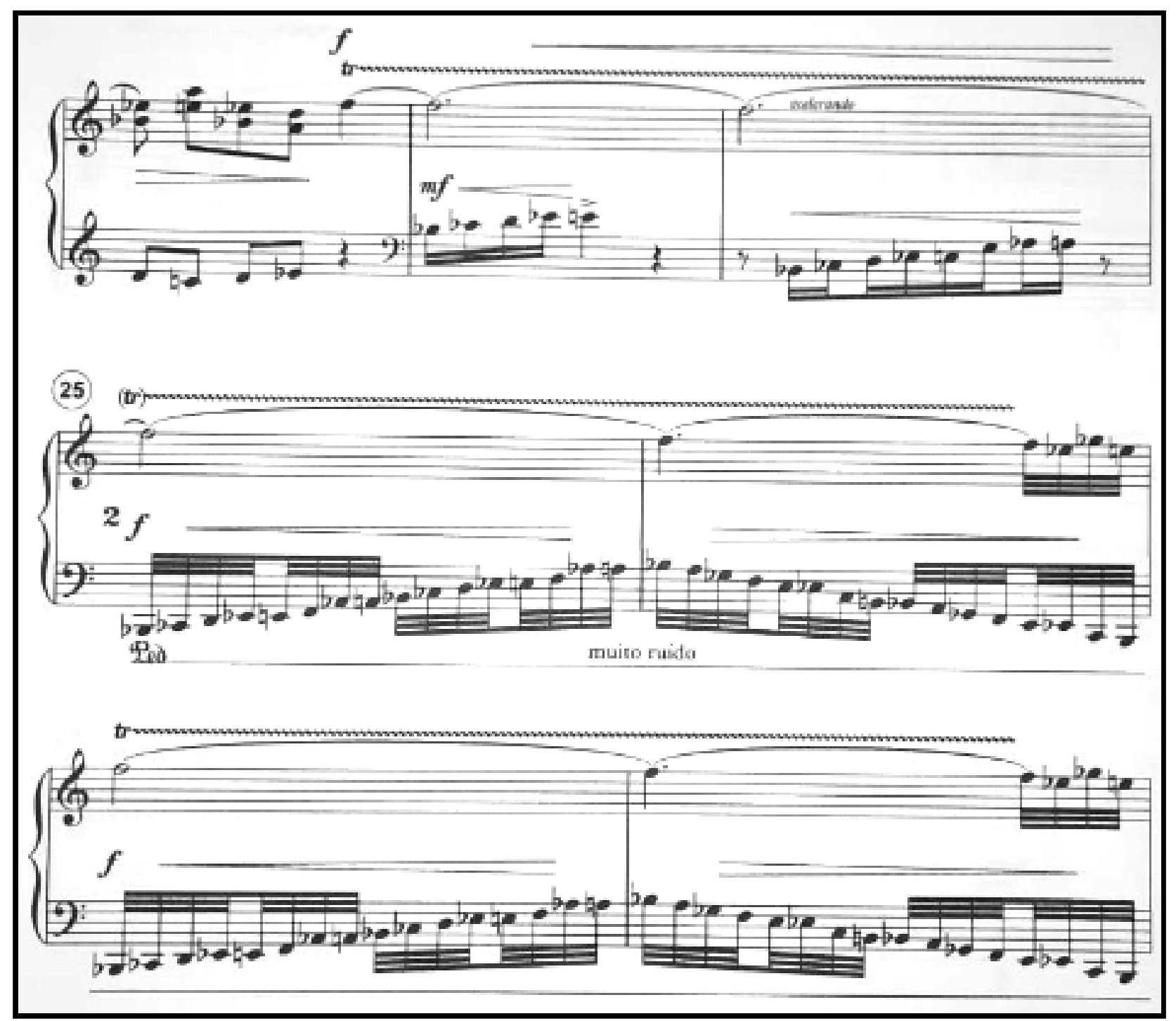

Example 5: Penalva's Piano Sonata no. 1 (1970). H. A. Moreira's version (2020), mm. 22-28.

The transition's second idea, T2 $(\mathrm{mm} .30-33)$, is prepared by a lower trill over the Bb-1 in measure 29, after the completion of T1. T2 has a contrasting vertical texture, utilizing alternating clusters in the middle and high regions of the keyboard (ex. 6, mm. 29-33). It is constructed from $\mathbf{1 8}$, and its texture is much less dense than the texture of 
the first idea. Nonetheless, due to the indications of fortissimo as well as the employment of pedal, it balances itself dynamically (ex. 6).

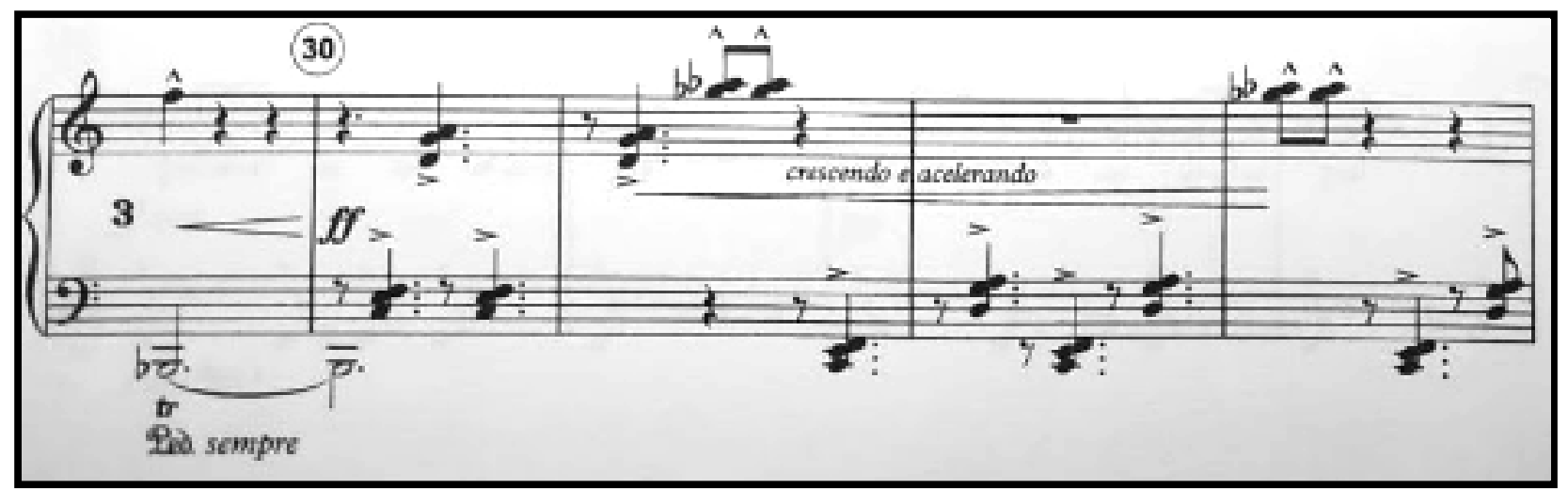

Example 6: Penalva's Piano Sonata no. 1 (1970). Ricordi's edition (1972), mm. 29-33.

The development (mm. 34-64) can be also divided into two parts according to its different textures: D1 (mm. 34-54) and D2 (mm. 55-64).

In D1 (mm. 34-54), Penalva employs an ostinato of undetermined clusters in the left hand ${ }^{33}$ expanding his musical idea. These clusters are placed so as to alternate the lower and higher ones on the first beat of each measure, creating a binary meter (ex. 7 , mm. 34-39).

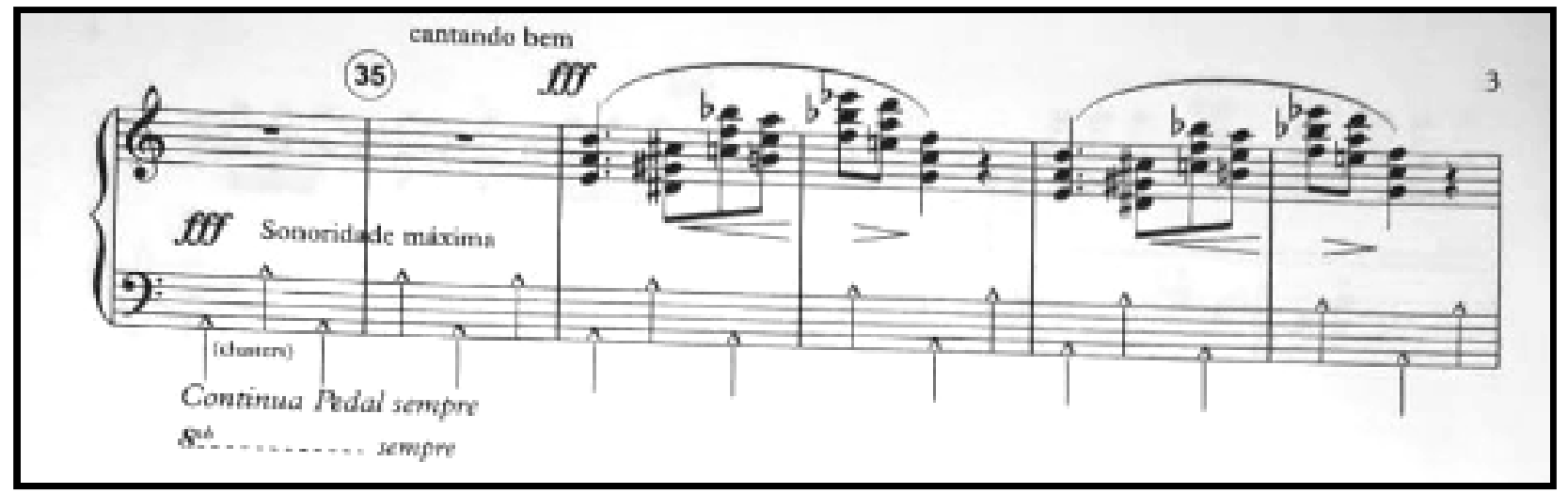

Example 7: Penalva's Piano Sonata no. 1 (1970). H. A. Moreira's version (2020), mm. 34-39.

${ }^{33}$ It should be played with the palm of the hands. Further details about Penalva's employment of clusters in this sonata and other works appear in J. Oliveira's dissertation (Oliveira, Jonathan Taylor de. 2013, p. 3-4. XXIII Congresso da Associação Nacional de Pesquisa e Pós-Graduação em Música, Natal/RN,2013. 
Additionally, a melodic line of quartal chords is superimposed, composed from elaborations on the initial Seresta motif of $\mathrm{D}-\mathrm{CH}-\mathrm{Bb}(\mathbf{O o})$. It comprises the entire D1 section, as shown in example 8 ( $\mathrm{mm} .36-44)$.

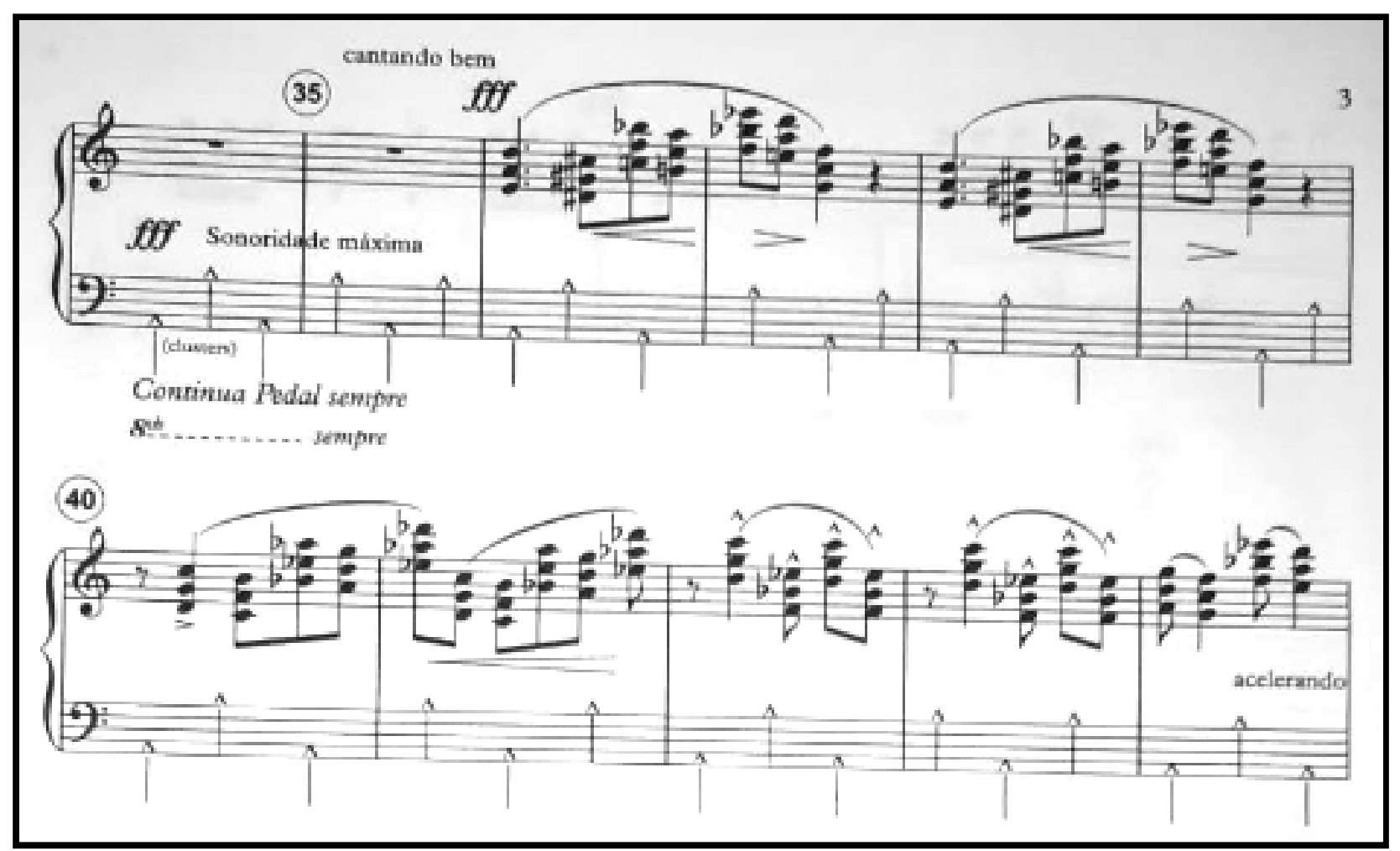

Example 8: Penalva's Piano Sonata no. 1 (1970). H. A. Moreira's version (2020), mm. 34-44. ${ }^{34}$

From measure 44, the music gradually accelerates. Motifs become shortened in a frenetic crescendo towards the culmination point, where unexpected "sêco" (dry) chords and clusters are written for the extreme regions of the piano (ex. 8-9, $\mathrm{mm}$. 44-54). Penalva's indication "acelerando loucamente" (speeding madly), illustrates the exact character he was intending in this section; further, it may cause us to wonder about his emotional state at that time (ex. 9, mm. 51-52). ${ }^{35}$

\footnotetext{
${ }^{34}$ Ricordi's edition of the Sonata no. 1 has a measure-numbering mistake: $\mathrm{m} .35$ is actually $\mathrm{m}$. 36 , which is corrected in my own version's examples.

${ }^{35}$ During this period (1970's), the Catholic Church had given Penalva a painful ultimatum, obliging him to choose between his two great passions, music and the priesthood (Gonçalves, 2009, p. 52).
} 


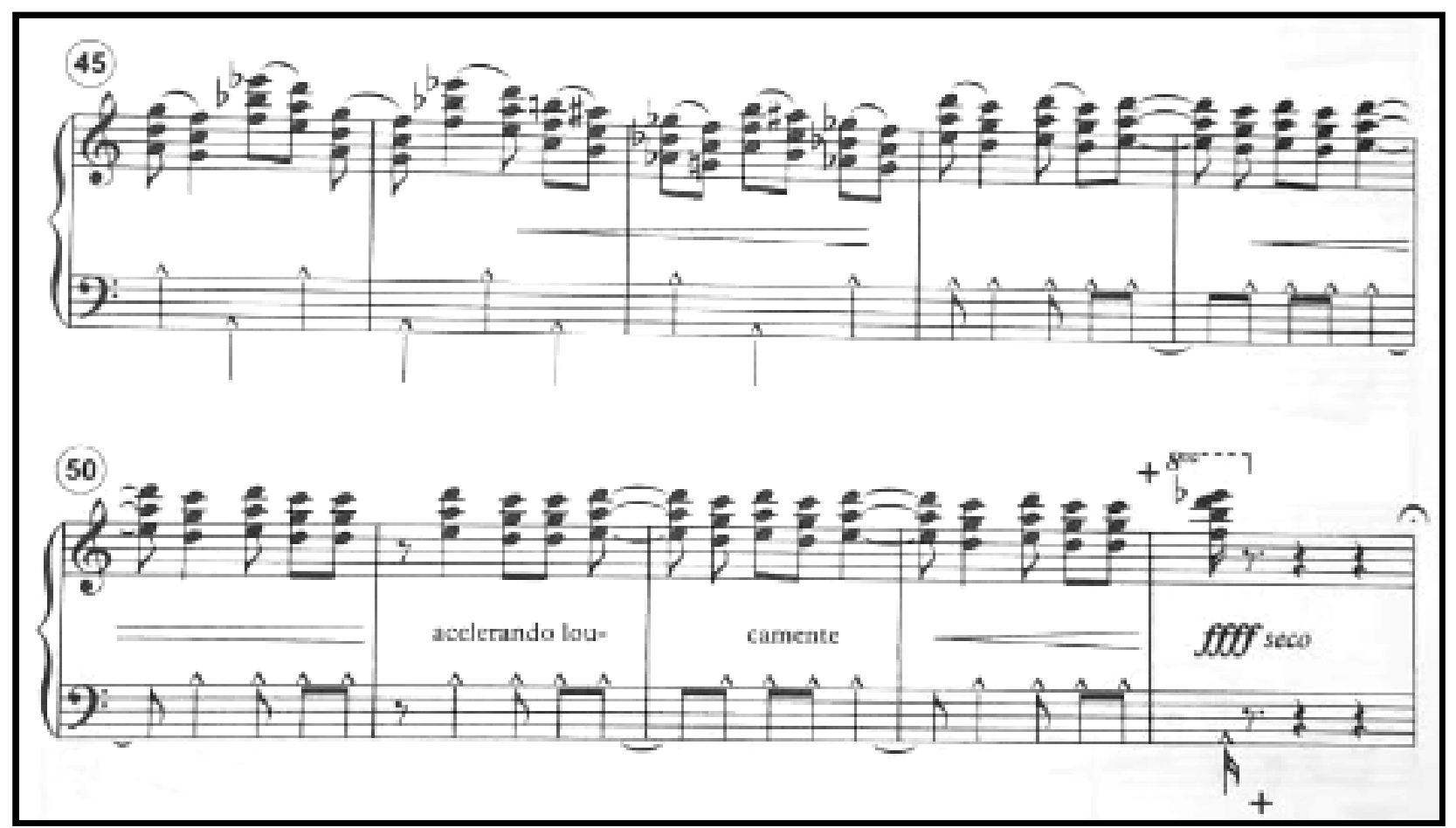

Example 9: Penalva's Piano Sonata no. 1 (1970). H. A. Moreira's version (2020), mm. 45-54.

D2 (mm. 55-64), the second main idea in the Development, employs the same initial sonata motif ( $\mathrm{D}-\mathrm{CH}-\mathrm{Bb})$; but here, it is verticalized and transposed using a number of different serial rows such as: Oo (ex. 10, mm. 55-56); O9 (ex. 10, mm. 57-58); O2, O4, 03 (ex. 11, mm. 61-62); 08, 03 (ex. 11, mm. 63-64). In measures 61-62, there is a bassline melodic motif, which is constructed from ROo's first four pitch classes (ex. 11).

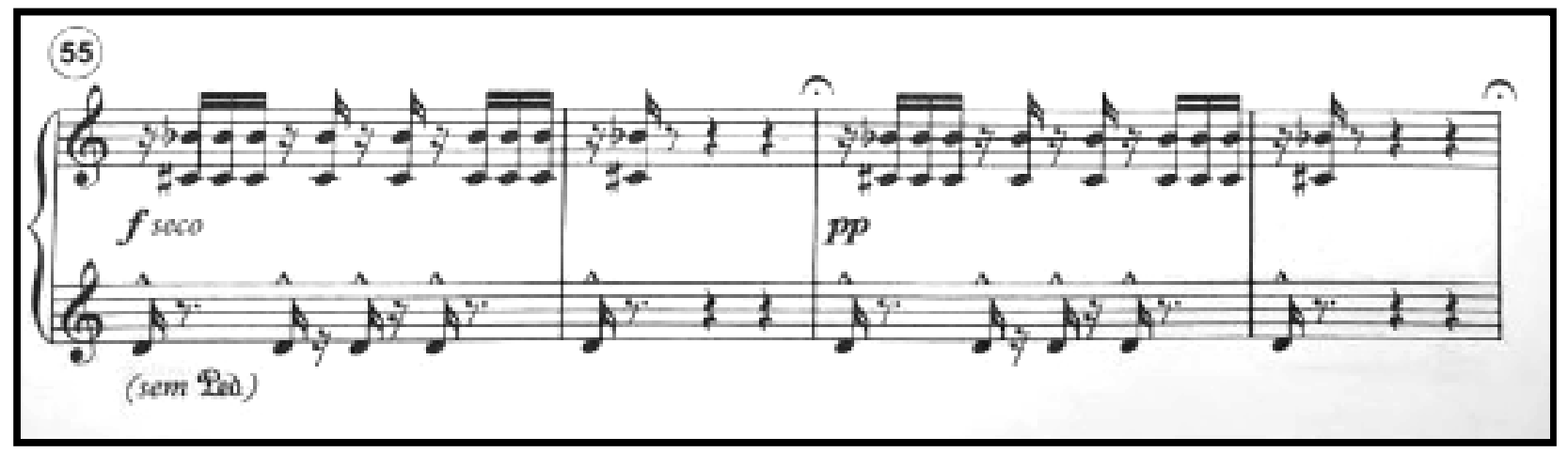

Example 10: Penalva's Piano Sonata no. 1 (1970). H. A. Moreira's version (2020), mm. 55-58. 


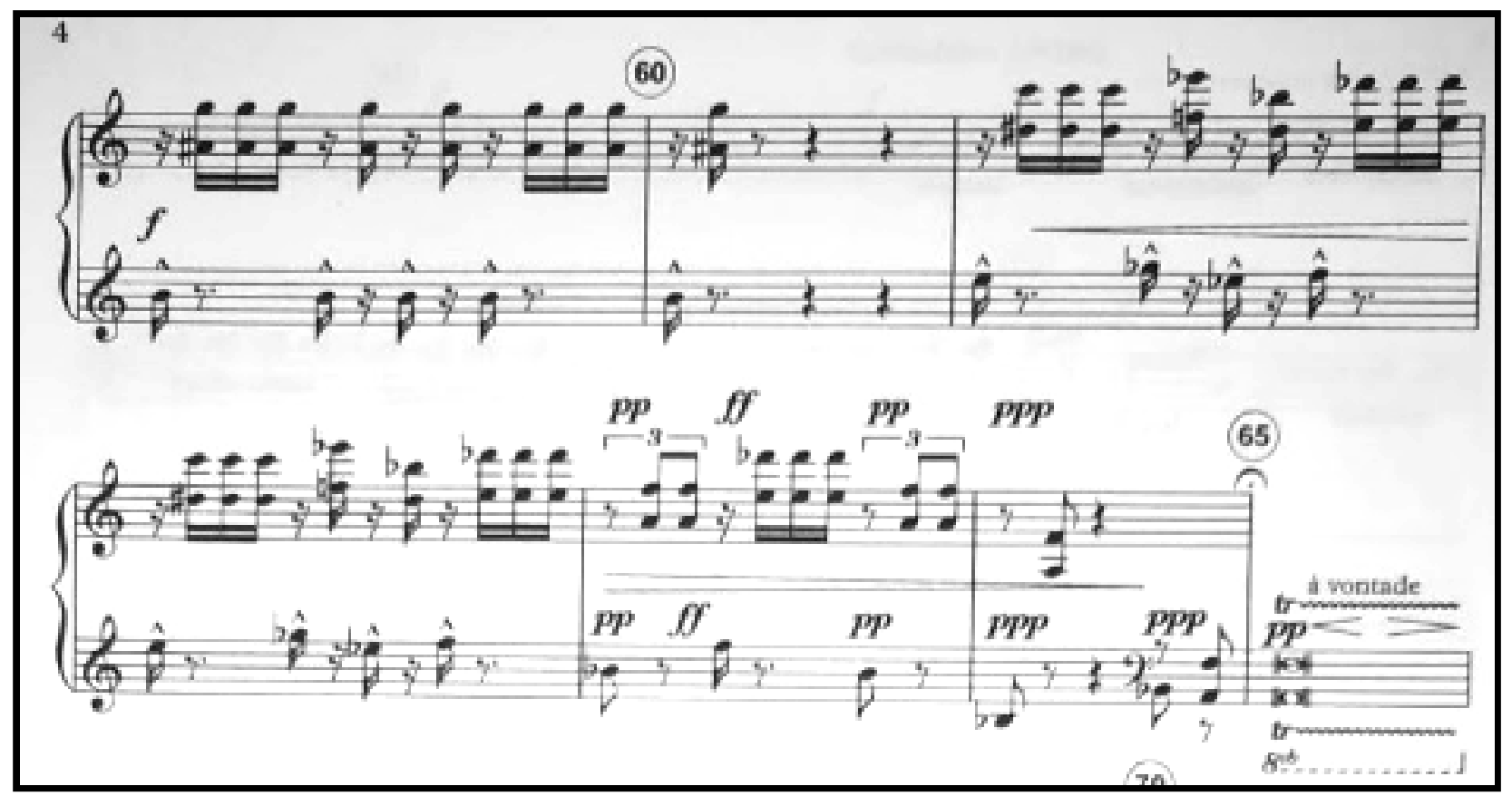

Example 11: Penalva's Piano Sonata no. 1 (1970). H. A. Moreira's version (2020), mm. 59-65.

D2 ends with abrupt dynamic changes, suddenly interrupted by a fermata (ex. 11, mm. 64). This is followed by a short transition (mm. 65-68) in two distinct parts: The first part is comprised of a free double trill over the interval of a minor 6th, taken from 08's last two pitch classes (ex. 11, m. 65). The second part is built from ROo's four-note melodic motif (E-F\#-D\#-F), marked a tempo (ex. 12, mm. 66-68). Note that this is the same melodic motif employed in measures 59 and 61 (ex. 11), which is actually the initial counterpoint of $\mathbf{A} 2$ (ex. 2, mm. 6-7). The rhythmic structure of ROo's four-note motif is so unexpected that it is virtually impossible to recognize the Seresta's original ternary pulse. 


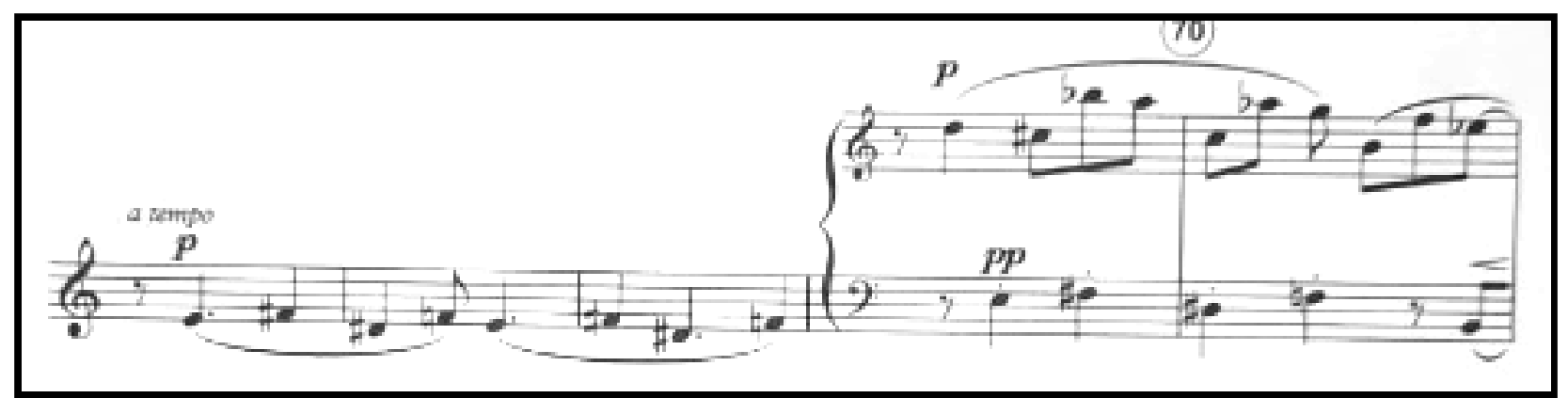

Example 12: Penalva's Piano Sonata no. 1 (1970). H. A. Moreira's version (2020), mm. 66-68.

With the recapitulation of themes $\mathbf{A}$ and $\mathbf{B}$ ( $\mathrm{mm} .69-76)$, the ternary meter returns. Theme $\mathbf{A}$ is presented in the same way as in the exposition, accompanied by a contrapuntal melodic line from ROo (ex. 13, mm. 69-71). Theme A (Oo) is wholly presented, but it is not repeated as in the exposition. ROo's melodic accompaniment is also slightly modified: It is one octave lower than in the exposition, it is rhythmically altered, and it is missing its last two pitch classes 11-0 (C\#-D) (ex. 13, mm. 69-71).

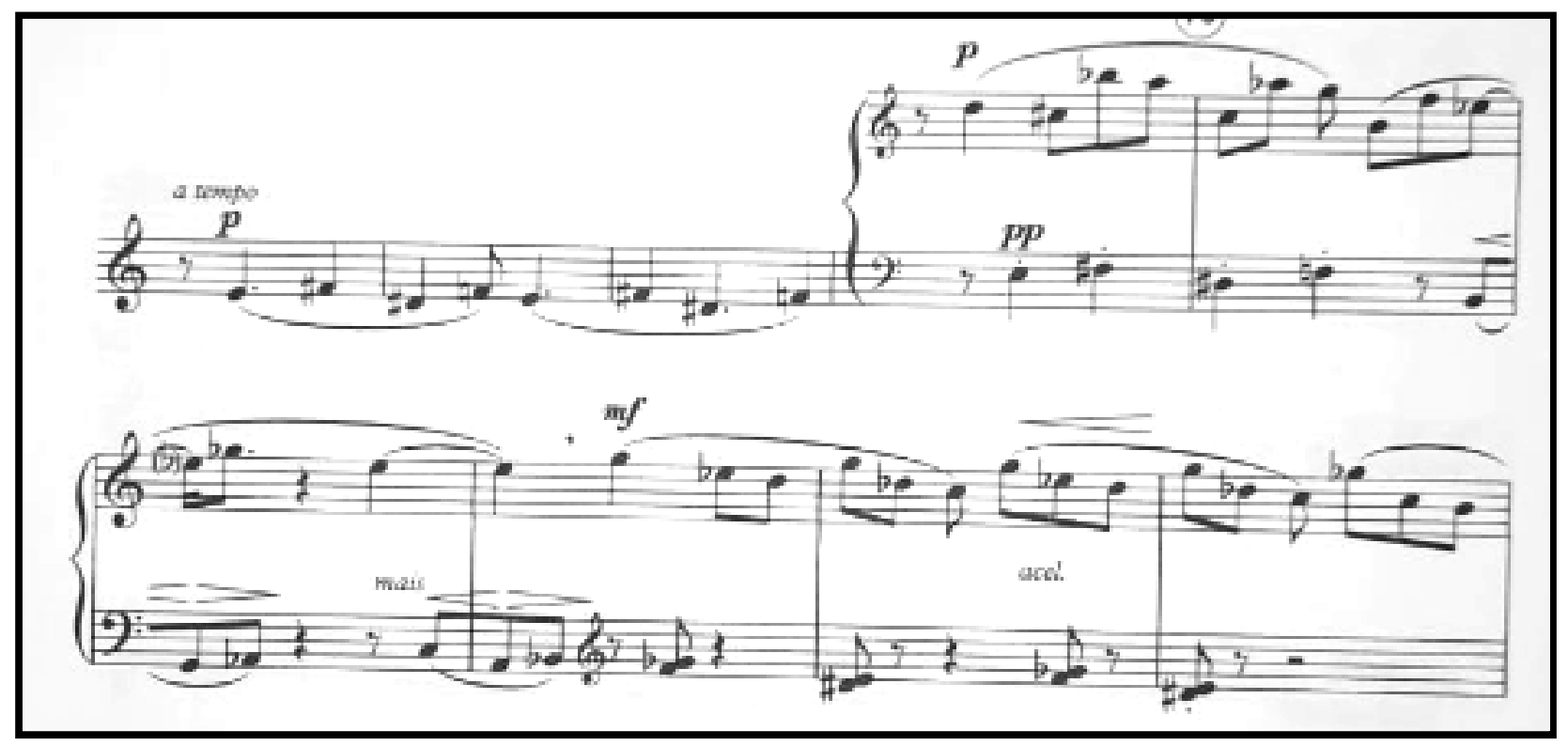

Example 13: Penalva's Piano Sonata no. 1 (1970). H. A. Moreira's version (2020), mm. 66-74.

Theme $\mathbf{B}$ returns next in the recapitulation; but this time, it includes tiny modifications of rhythm as well as adding its third pitch class "E" at the end (ex. 14, mm. 
72-76). As in the beginning of the exposition, its series 05 also lacks the pitch class 6 (Ab). Theme B's accompaniment of clustered dyads also remains exactly the same here in the recapitulation. Differently from the exposition, the recapitulation presents theme $\mathbf{A} \mathbf{3}$ theme again after B1, keeping the original bass line, although, without the first Oo's pitch class 0 (D). It is also followed by a slightly modified imitation using 05 (ex. 14, mm. 76-78). This passage finishes with a single, middle-register melodic line, drawn from the exposition's A3 (ex. 14b, mm. 12-13 - 05, RI1 and RI3) (ex. 14, mm. 79-80).

Seresta ends with a lean-textured coda, made up of an insistent motif of two notes, the last two pitch classes of Oo, in dynamic crescendo, ushering in the rhythmic and energetic Desafio (ex.15, mm. 81-85).

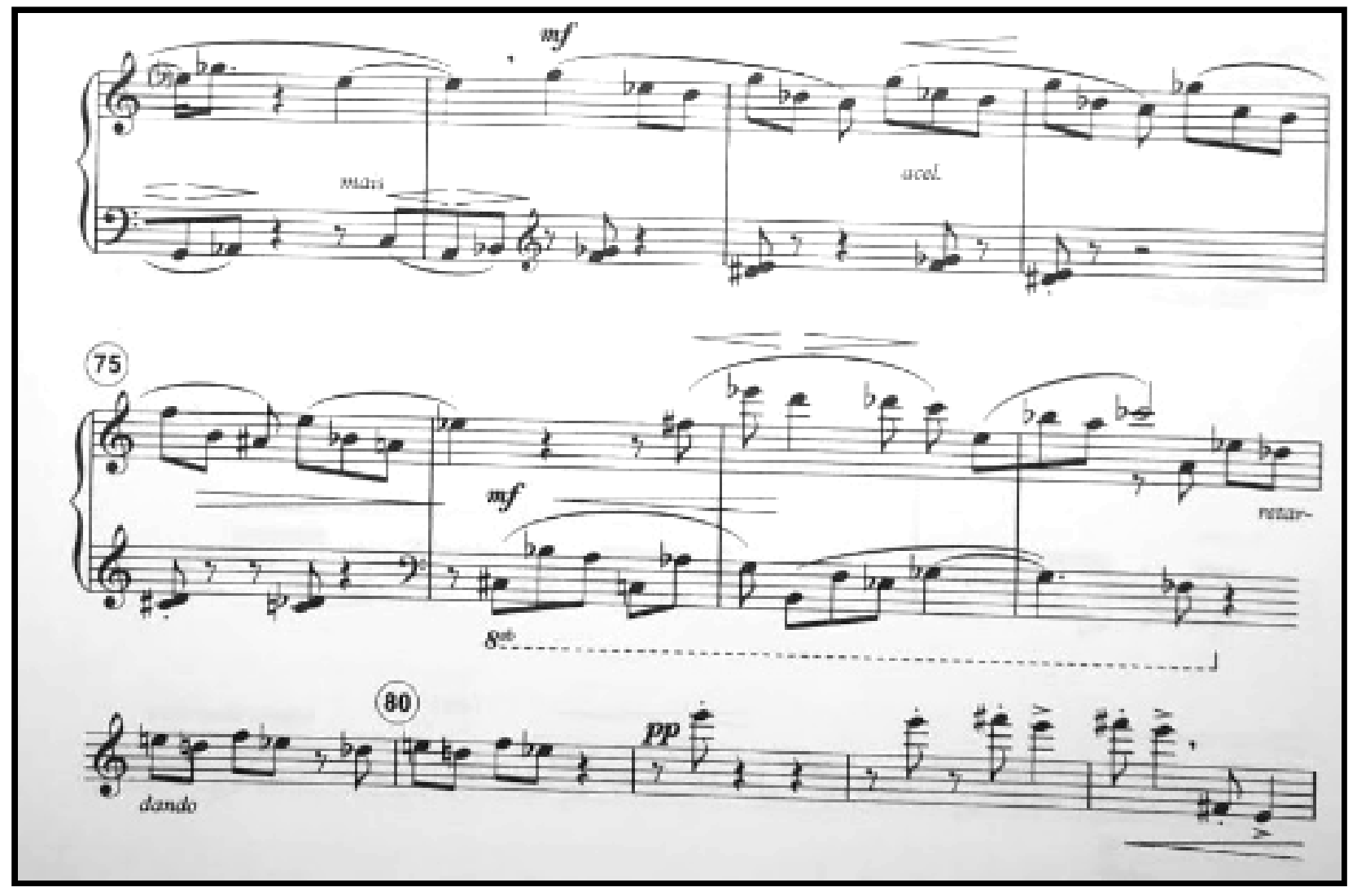

Example 14: Penalva's Piano Sonata no. 1 (1970). H. A. Moreira's version (2020), mm. 71-83. 


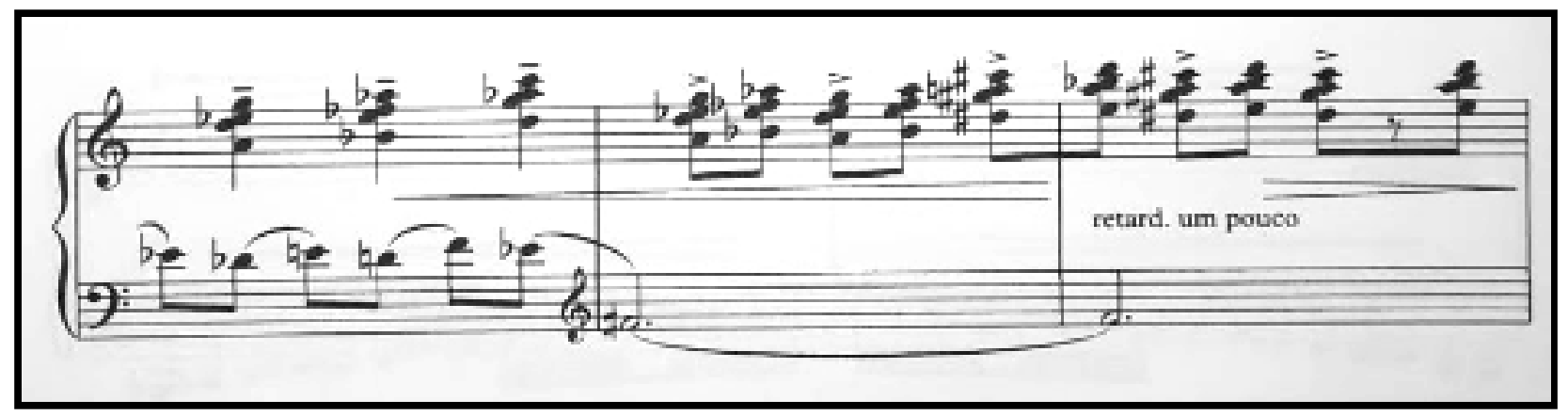

Example 14b: Penalva's Piano Sonata no. 1 (1970). H. A. Moreira's version (2020), mm. 12-14.

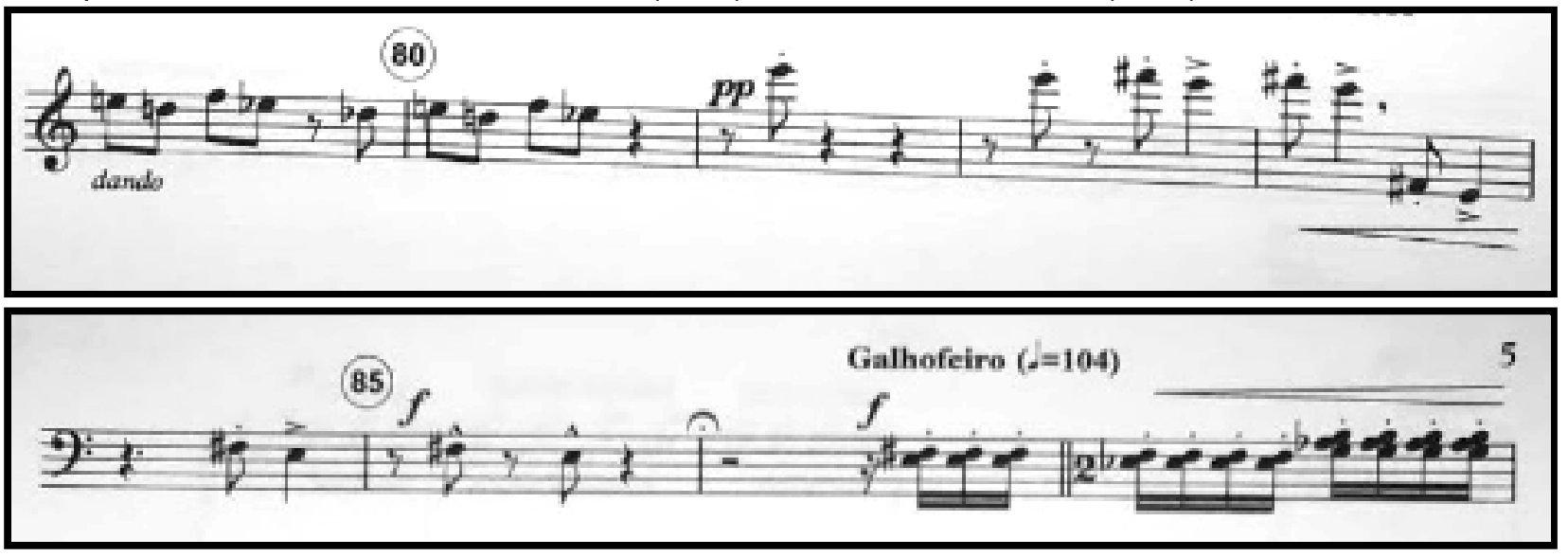

Example 15: Penalva's Piano Sonata no. 1 (1970). H. A. Moreira's version (2020), mm. 79-87.

\section{Desafio}

The section called Desafio is not structured in any classical form. It bears the character mark "galhofeiro" (mischievous), a Portuguese adjective which perfectly describes the Brazilian popular genre, desafio. Typically, this genre includes two singers accompanied by one or more guitars and/or percussion instruments. Sometimes only guitars or only percussion instruments are used; but in any case, the singers "provoke" each other by improvising mockingly funny verses on the spot. 
This Desafio can be outlined as follows:

\section{A-B-C-D (coda)}

A: (mm. 86-101)

A1 (mm. 86-90;90-94) - A2 (mm. 93-97;97-101)

B: (mm. 101-114)

B1 (mm. 101-106) - B2 (mm. 107-114)

C: $(\mathrm{mm} .115-125)$

C1 (mm. 115-120) - C2 (mm. 120-125)

D: (mm. 126-147)

Coda (mm. 148-151)

Section A (mm. 86-101) can also be divided into two parts: A1 (mm. 86-90) and A2 (mm. 93-97). Section A1 (mm. 86-90) starts with a percussive texture via clustered dyads and trichords using ROo (ex. 1, mm. 86-90). After a melodic interjection of the initial Seresta's four-note motif (Oo: D-C\#-Bb-A) transposed to O2 (E-D\#-C-B), section A1 is entirely repeated (ex. 2, mm. 90-94). 


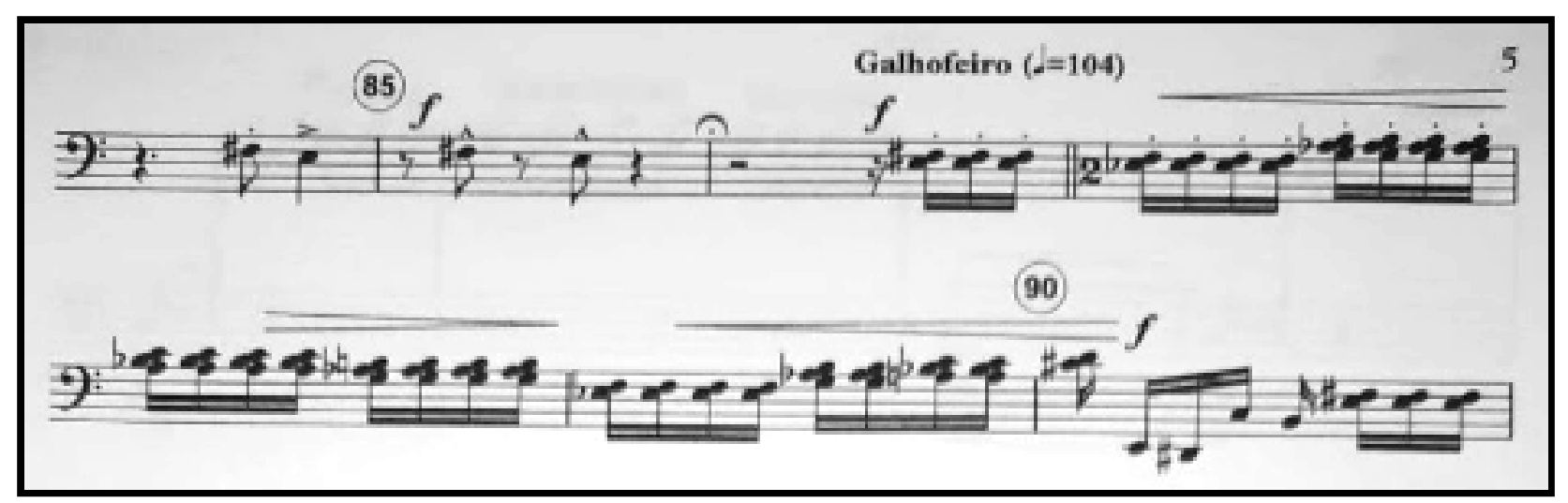

Example 1: Penalva's Piano Sonata no. 1 (1970). H. A. Moreira's version (2020), mm. 84-90.

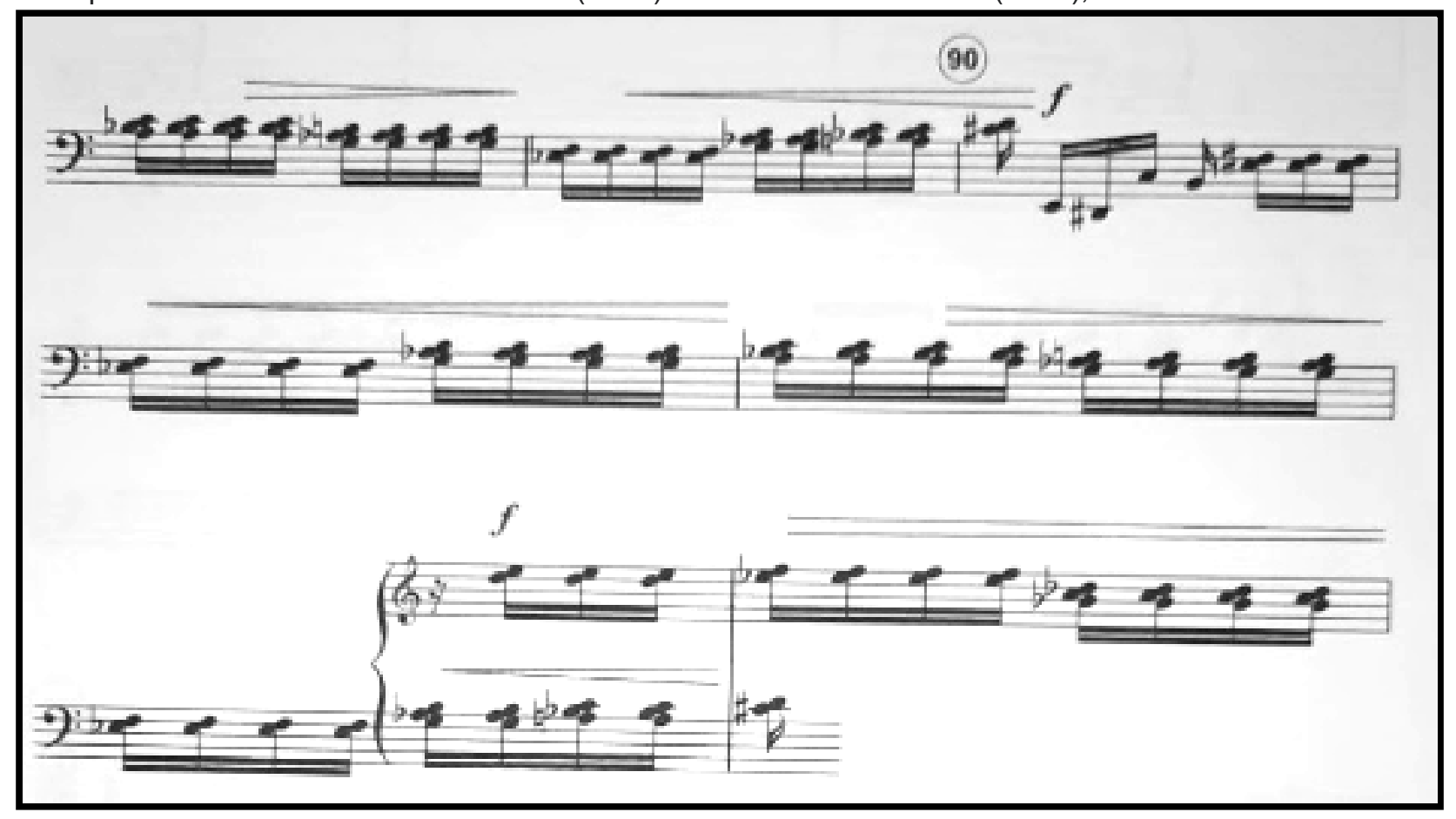

Example 2: Penalva's Piano Sonata no. 1 (1970). H. A. Moreira's version (2020), mm. 88-94.

Section A2 (mm. 90-94) starts before the entire presentation of A1 is completed (mm. 86-90) by interpolation (ex. 2, m. 93). Section A2 is constructed from R1, and its clustered dyads and trichords are a mirrored version of those from section A1. (ex. 3, mm. 93-97). ${ }^{36} \mathbf{A} 2$ is also entirely repeated after another interjection of the four-note

${ }^{36}$ This mirrored writing is also well observed in Gonçalves' dissertation (2009, p. 73). 
initial motif from R09. It utilizes the same mirrored writing and incorporates a slight modification at the end, in order to resemble the melodic contour of $\mathbf{A} 1$ (ex. 3, 97-101). ${ }^{37}$

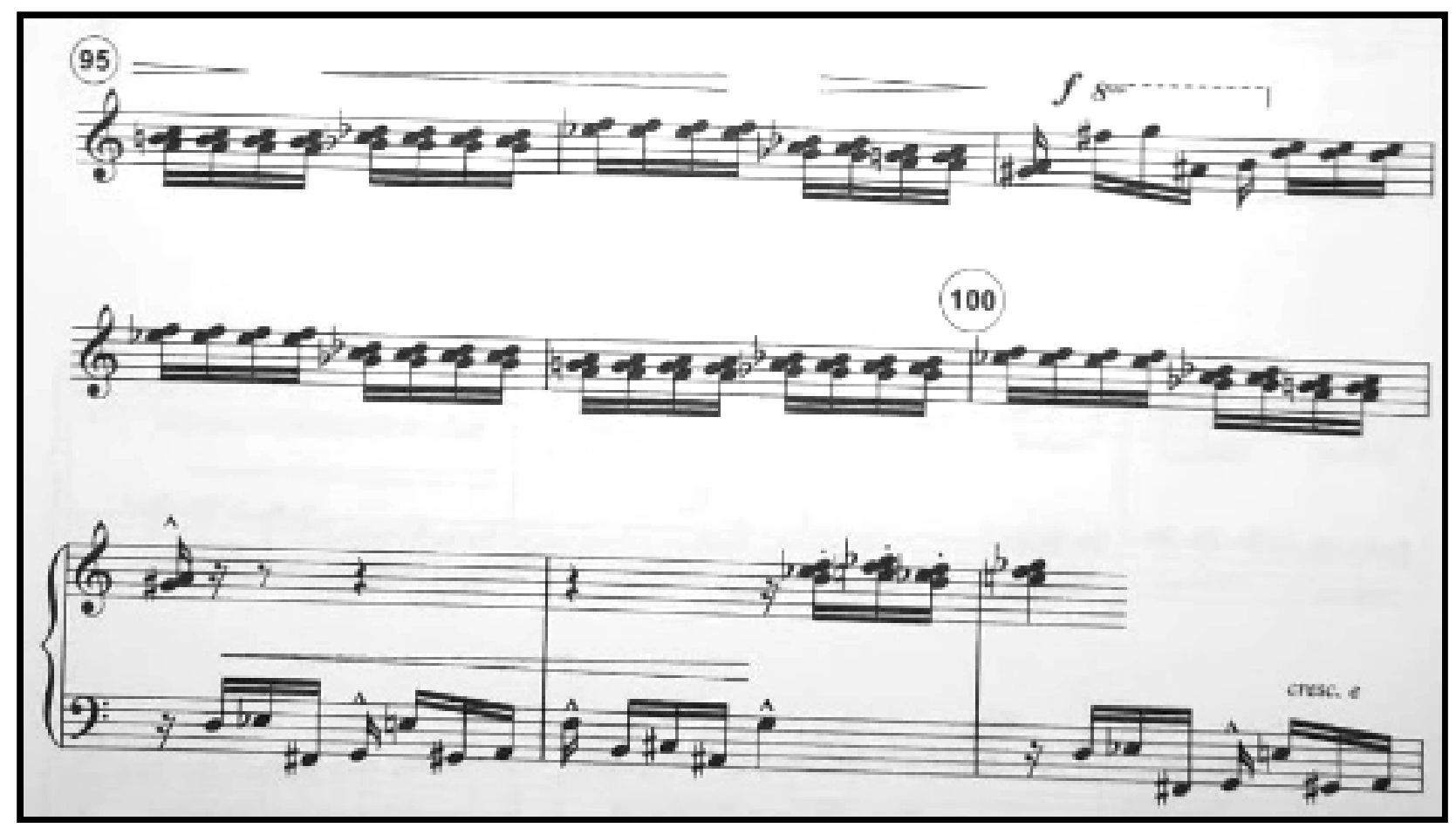

Example 3: Penalva's Piano Sonata no. 1 (1970). H. A. Moreira's version (2020), mm. 95-103.

Section B also has two contrasting parts: B1 (mm. 101-106) and B2 (mm. 107-114).

The material in B1 (mm. 101-106) inverts the roles of the material in the A sections (mm. 86-101). Now, elaborations of section A's melodic motif interjections, drawn on lo, become the main idea, and the clustered trichord material takes charge of the interjection instead (ex. 4, mm. 101-102). In the second part of B1, (ex. 4, mm. 103-107), the melodic-motif idea is extended by repeating some pitch classes of lo. It is abruptly interrupted at the very end by an energetic trill with a crescendo followed by a fermata (ex. 4, mm. 107-108).

\footnotetext{
${ }^{37}$ Note that, despite this mirrored writing, the last three clusters of $\mathbf{A} 1$ (ex. 20, mm. 88-89) are exactly mirrored just at the very end of B2 (ex. 22, mm. 99-100).
} 


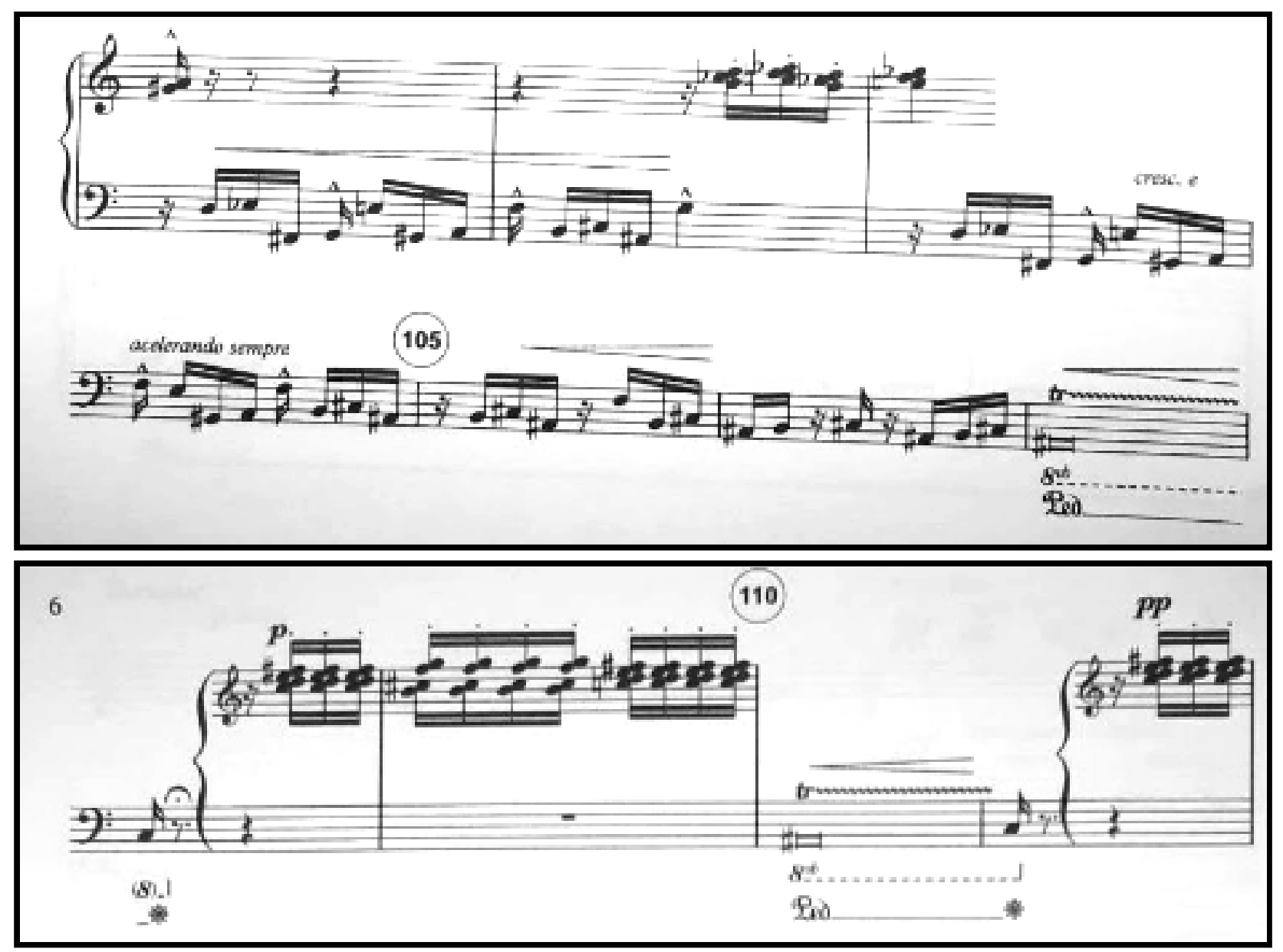

Example 4: Penalva's Piano Sonata no. 1 (1970). H. A. Moreira's version (2020), mm. 101-111.

Section B2 (mm. 107-114) employs clustered dyads and trill materials from both A sections. The mirrored relationship between the two sections of $\mathbf{A}$ (A1 and A2) is repeated and obvious this time

In the first phrase of B2, both of the previously used dyads are superimposed to create four-note clusters from RI6 (upper dyads) and RI1 (lower dyads) (ex. 5, mm. 108-112).

In the second phrase of B2 (ex. 6, mm. 112-114) the clusters arise from I6, I1 (m. 113) and RI9, R11 (m. 114). The final cluster in section B2 (ex. 6, m. 114) is constructed from RO6 (lower dyad) and ROo (upper dyad). The trills, employed as 
interjections in this section (ex. 5, mm. 107 and 110), use pitch classes from clusters that occur just prior to them.
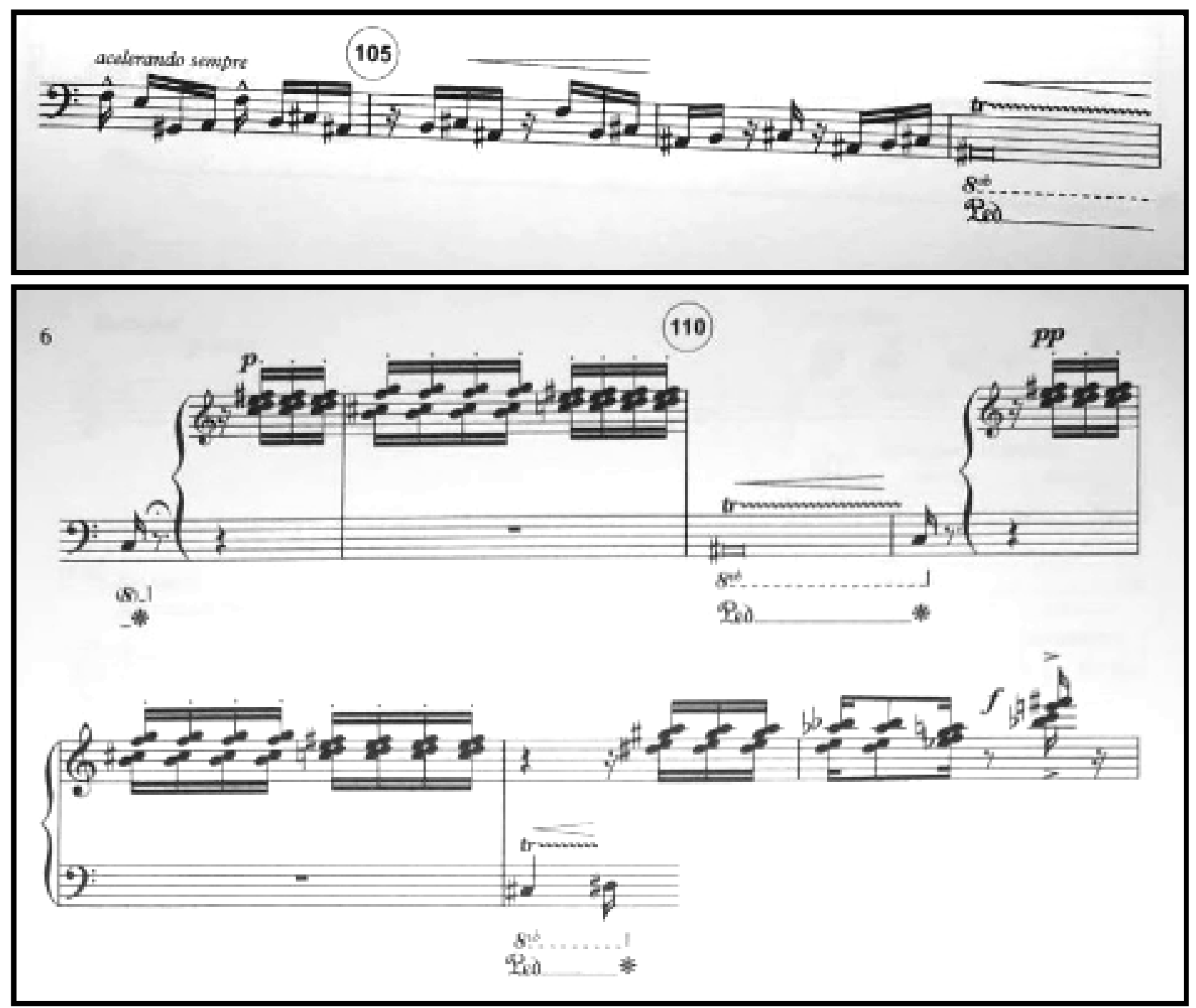

Example 5: Penalva's Piano Sonata no. 1 (1970). H. A. Moreira's version (2020), mm. 104-114. 


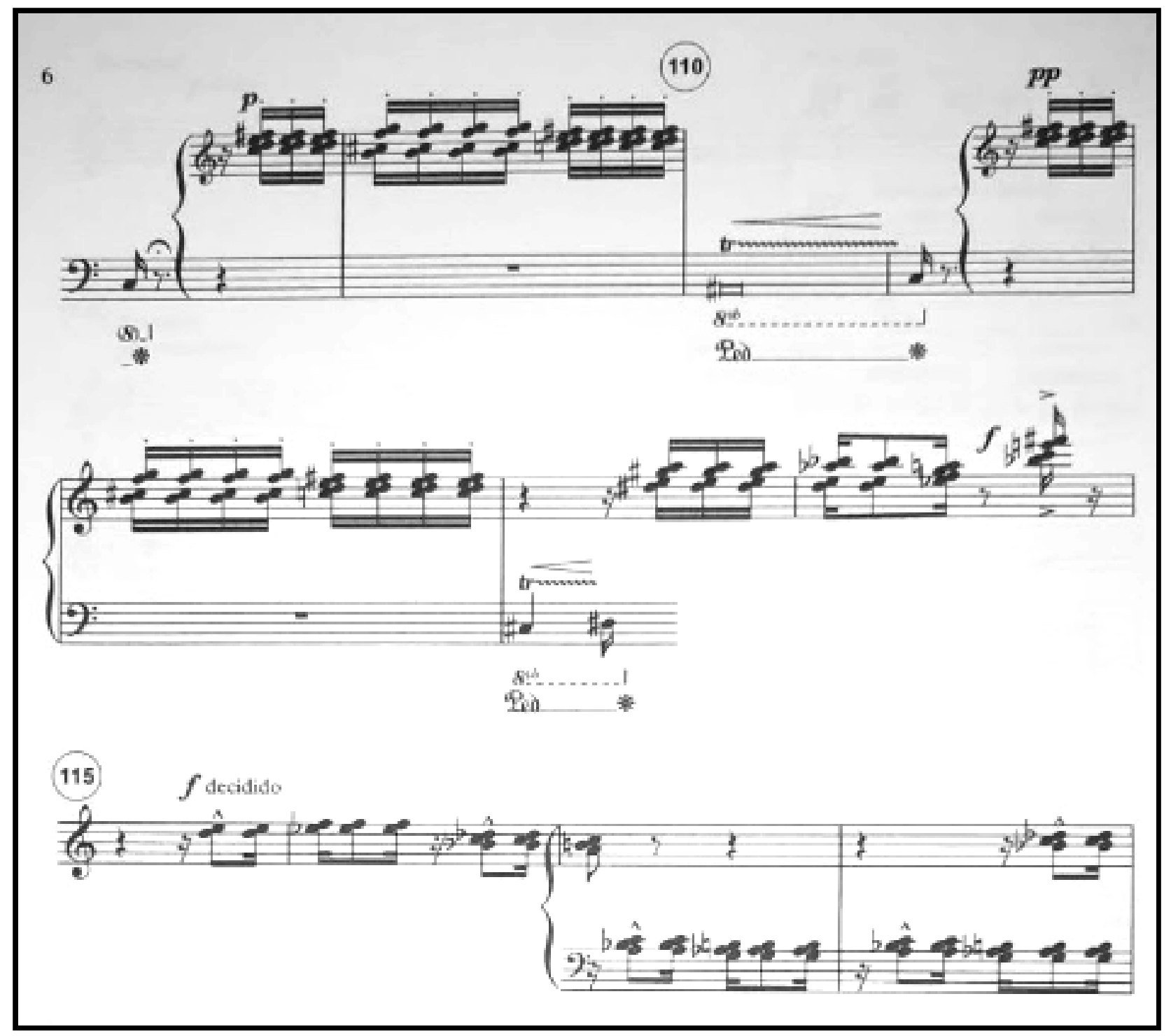

Example 6: Penalva's Piano Sonata no. 1 (1970). H. A. Moreira's version (2020), mm. 108-118.

In section C (mm. 115-125), Penalva once again uses mirrored writing; but this time, he alternates the sixteenth rhythmic pattern from the previous section $\mathbf{A}(\mathrm{mm}$. 86-101) with different rhythms, such as rest+eighth+sixteenth, and sixteenth triplets (ex. 7, mm. 115-118; mm. 123-124, respectively). 


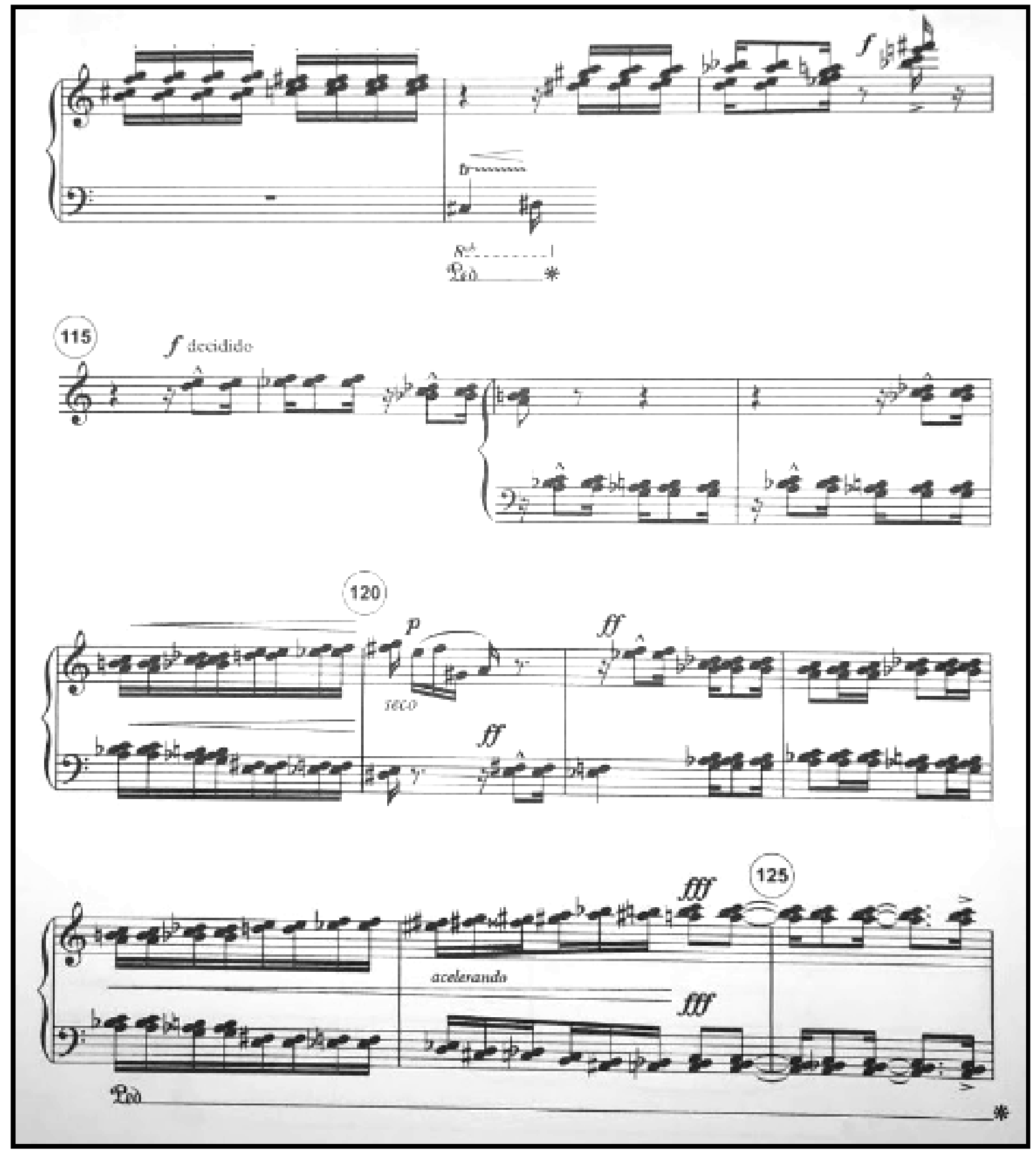

Example 7: Penalva's Piano Sonata no. 1 (1970). H. A. Moreira's version (2020), mm. 112-125. 
Section C (115-125) can also be divided into two parts: C1 (mm. 115-120) and C2 (mm. 120-125).

Section C1 (115-125) begins with clustered dyads and triads taken from Section B material. Initially, the texture is comprised of clustered dyads and trichords located in the upper region of the piano (ex. 7, mm. 115-117) ${ }^{38}$ Afterward, cluster material from theme $\mathbf{A}$ is presented in the lower region of the piano (ex. $7, \mathrm{~mm} .117-118)$. Next, the upper and lower regions of clustered material that just appeared are written simultaneously in mirrored fashion in measure 117 (ex. 7, mm. 119). Intermingled with the initial Desafio melodic motif in measure 119, this same material is presented yet again, now emphasized by a chromatic passage incorporating crescendo and accelerando, that culminates in fortissimo clustered trichords in the extreme regions of the piano (ex. 7, mm. 121-125).

Section D (mm. 126-147) summarizes all of the compositional materials employed throughout the sonata: ROo (ex. 8, mm. 126-128); clustered trichords (ex. 12, mm. 132-133, 135-137); theme A (ex. 13, mm. 138-140); theme B fragments (ex. 14, mm. 143-146); and quartal chords (ex. 14).

\footnotetext{
${ }^{38}$ As well observed by Gonçalves (2009, p. 78 [footnote 37 ]) and corroborated by Dottori's manuscript-based version (2011, p. 7, m. 105-112), there is a possible mistake in measure 115. According to Gonçalves, in the second beat of this measure, the B3 and D4 should be flattened, in order to fit with the Desafio B theme's clustered trichords.
} 


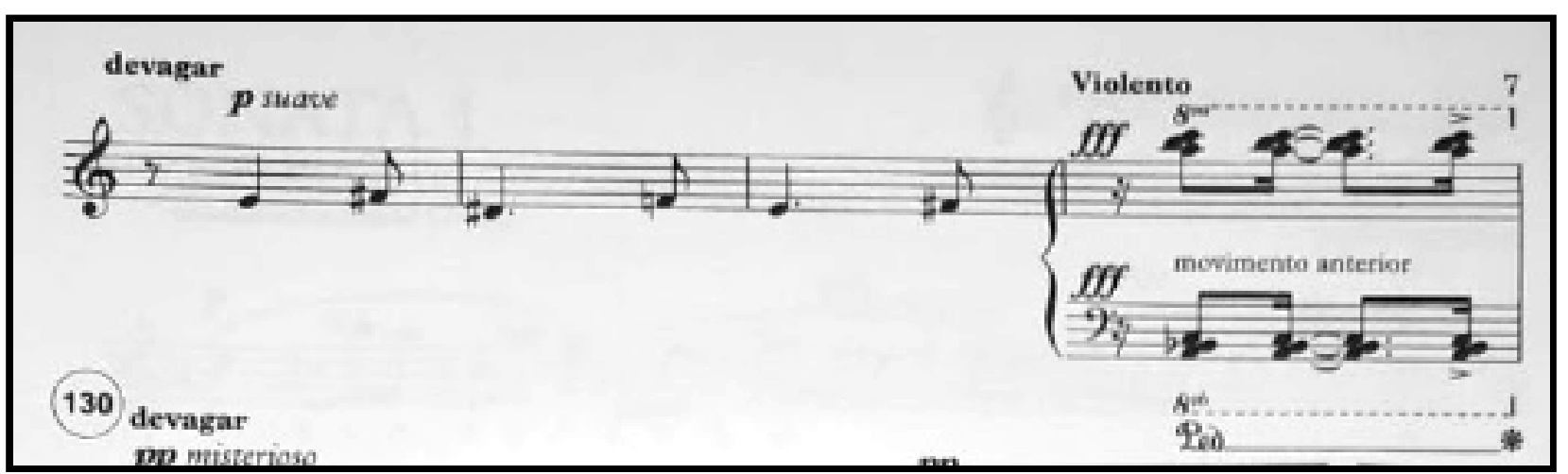

Example 8: Penalva's Piano Sonata no. 1 (1970). H. A. Moreira's version (2020), mm. 126-128.

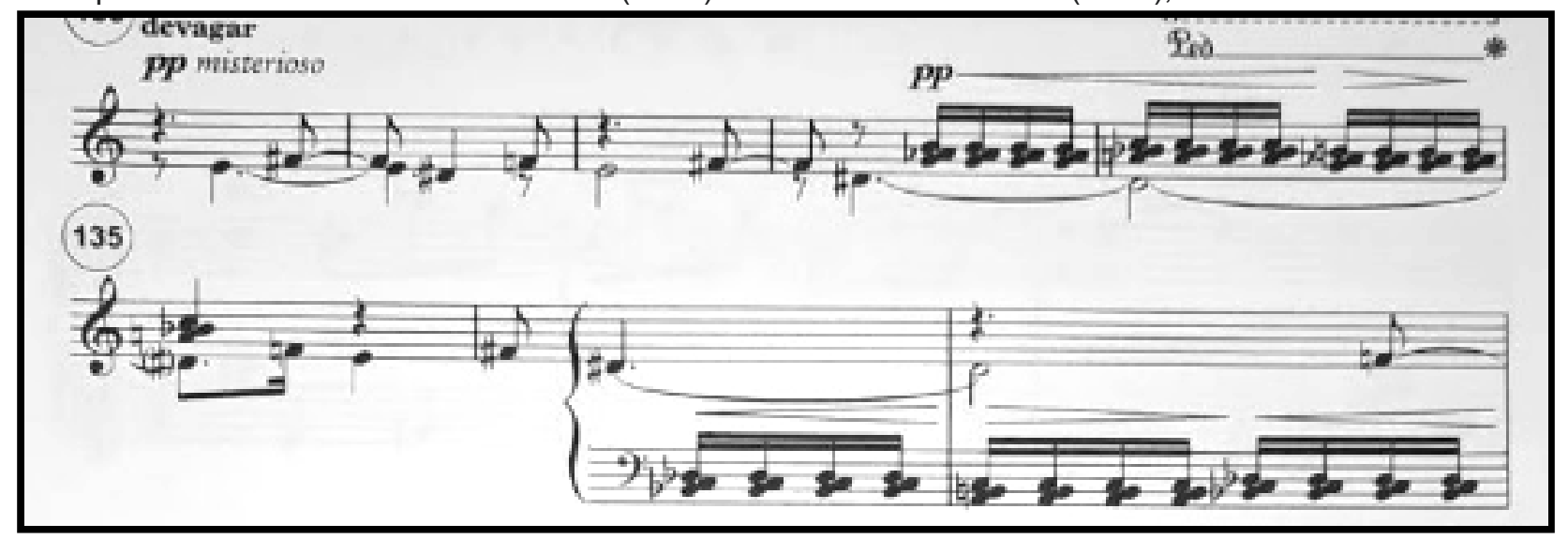

Example 9: Penalva's Piano Sonata no. 1 (1970). H. A. Moreira's version (2020), mm. 130-137.

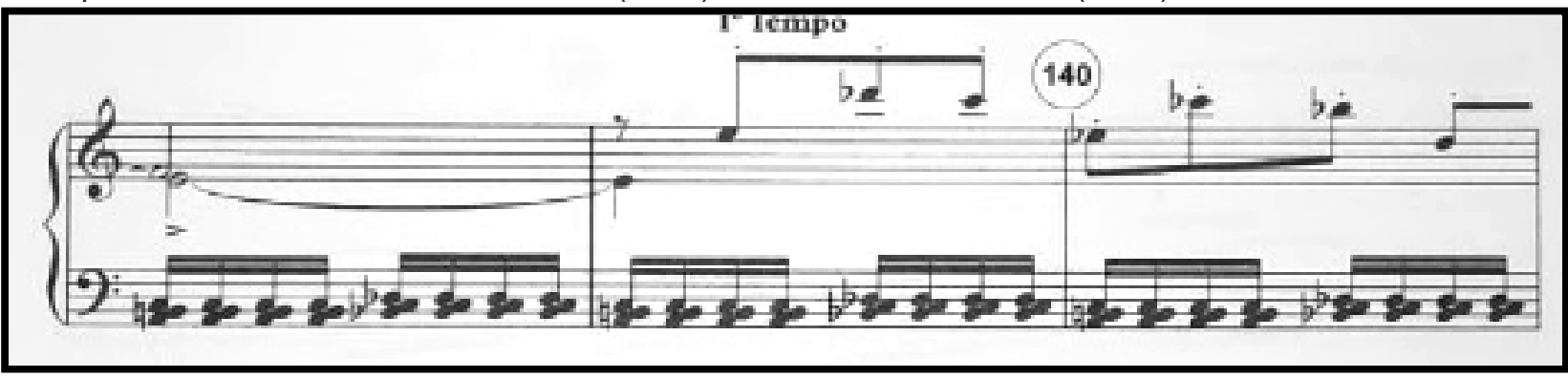

Example 10: Penalva's Piano Sonata no. 1 (1970). H. A. Moreira's version (2020), mm. 138-140.

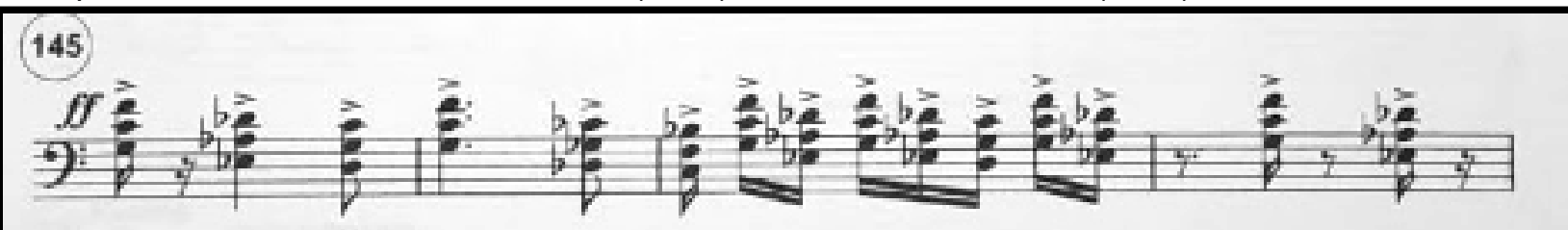

Example 11: Penalva's Piano Sonata no. 1 (1970). H. A. Moreira's version (2020), mm. 145-148.

The coda starts with a fragment of the Seresta's A theme in the bass line, accompanied by quartal chords in the upper region of the piano. These chords are built from RO10's third and fourth pitch classes (Db-Eb) (ex. 12, mm. 148-151). 


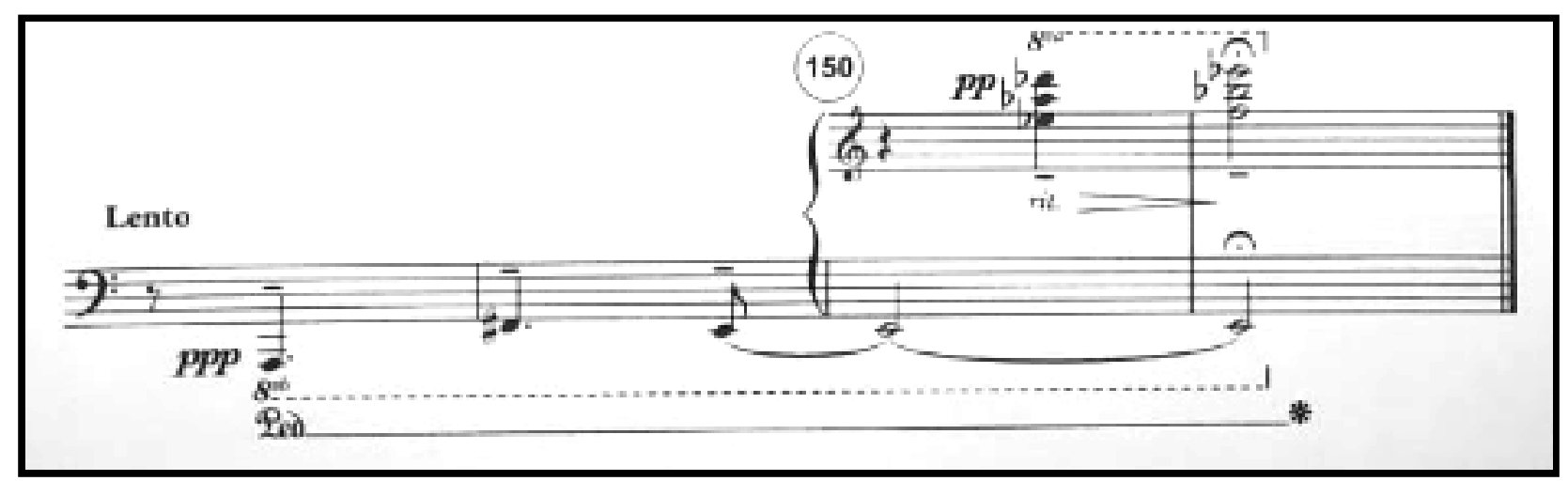

Example 12: Penalva's Piano Sonata no. 1 (1970). H. A. Moreira's version (2020), mm. 148-151.

The Sonata no. 1 represents the composer's serial phase. While employing traditional forms, it mixes Brazilian folk material with twelve-tone technique, corroborating Schoenberg's idea of a broadened adaptation of serial technique to other musical cultures. The Seresta and Desafio reflect these Brazilian genres by a subtle and sophisticated stylization of their inherent instrumentation, rhythmic organization, melodic contour, and motivic elaboration. 


\subsection{Sonata no. $2(1960)$}

According to Fregoneze, Penalva stated that "The Sonata No. 2 has Mozart's proportions." (Fregoneze, 1992, p. 40). As in most classical sonatas, sonata-allegro form appears in the first movement. Penalva only assigned a metronome tempo for the first movement (quarter=120), allowing the other tempi to be chosen by the performer in keeping with his written character indications. Movements two and three of Sonata no. 2 are the only two movements among all three of Penalva's sonatas that have no metronome marking.

This sonata was actually the first piano sonata composed by Penalva, dating from 1960. Initially, he never intended to publish it. It was incorporated into his output catalogue only later, when he had already published his second sonata, written in 1970, as "Sonata no. 1," with Ricordi Brasileira in 1972. Thus, his actual first sonata, from 1960, received the title, "Sonata no. 2."

Sonata no. 2 has three movements: I. Moderato, II. Andante cantabile, and III. Rondó-Allegro. According to the composer (as cited in Prosser, 2000, pp. 30-31), each of the three movements pays homage to a different composer's style: Gershwin and Bartók (first movement), Carmago Guarnieri ${ }^{39}$ (second movement), and Webern ${ }^{40}$ (third movement). Penalva comments that no musical material was directly quoted from these composers at all, nor particular melodies, nor specific works. He utilized only their essential compositional procedures, “...things that we think Bartók and other composers used to do." (Fregoneze, 1992, p. 40).

${ }^{39}$ Carmago Guarnieri (1907-1993) was an important modern Brazilian composer.

${ }^{40}$ Anton Webern (1883-1945). 


\section{Moderato}

Exposition: (mm. 1-27)

Introduction (mm. 1-4)

A (mm. 5-7)

Transition (8-10)

B1 (mm. 10-19)

B2 (20-26)

Development: (mm. 28-45)

D1 (mm. 28-36) - D2 (mm. 37-46)

Recapitulation:( mm. 47-72)

The first section of the moderato can be subdivided into three ideas:

Introduction (mm. 1-4), A (mm. 5-7), and Transition (mm. 8-10). Written in A minor, the Introduction starts with a modal melody in octaves that opens the first movement. It is accompanied by chords made of 6ths and 7 ths, all in the dynamic " $f f$ " (ex. $1, \mathrm{~mm}$. 1-4). The lack of the leading tone (G\#) in both the melodic line and in the harmony gives the initial theme a modal character.

The second idea $\mathbf{A}$, is more melodic and expressive than the first introductory material, and an inner voice stands out from its ostinato accompaniment (ex. $2, \mathrm{~mm}$. 5-7). Alexandre Gonçalves also points out that this accompaniment resembles Bartók's pianistic writing (Gonçalves, 2009, p. 29). Next, Penalva provides a transition that is harmonically unstable, leading to the second theme, also in A minor (ex. 2, mm. 8-10). 
There are abrupt harmonic changes ( $\mathrm{A}$ minor to $\mathrm{Gb}$ ) as well as a texture of parallel 4 ths, 5ths, and octaves, which generate great tension leading into theme B1. This passage is technically challenging for the pianist.

Generally, note that the modal language of the sonata is occasionally affected by pitches outside the norm and by some chromatism, giving the piece a modern character. As an example of this, at the very beginning, Penalva uses some pitches normally incompatible with Aeolian A minor:- D\#, Eb, Bb (ex. 2, mm. 7-8). Previous analysis of this sonata by the scholars Fregoneze (1992, p. 40) and Prosser (2000, p. 30), attributes this to an "incidental atonality," employed on a regular basis by the composer during this stylistic time period. However, in my opinion, this particular case (mm. 7-8) is more likely due to the influence of Gershwin and his use of "blue" scale notes in the jazz idiom, especially because Penalva himself noted that he was imitating Gershwin's style.

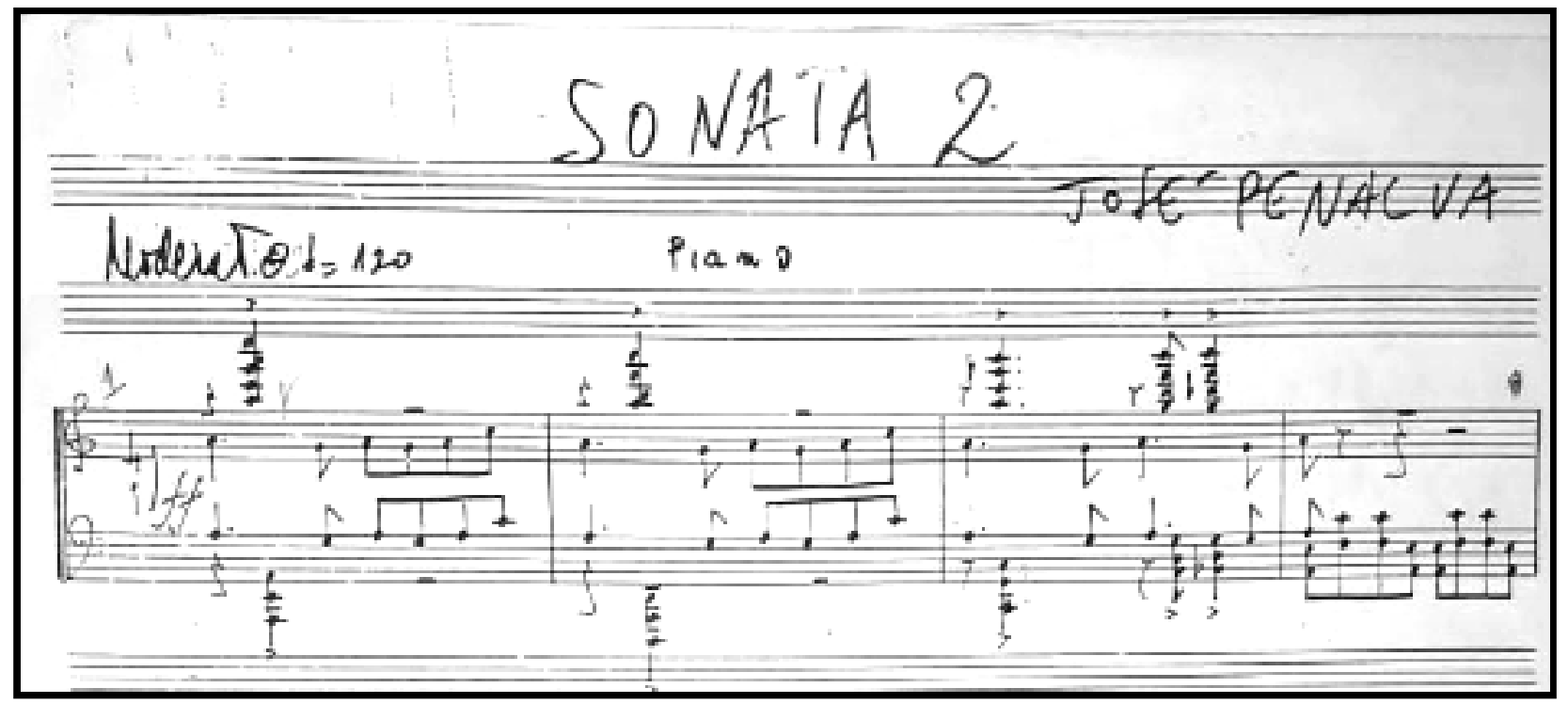

Example 1: Penalva's Piano Sonata no. 2 (1960). Manuscript's 1st movement (moderato), mm. 1-4. 


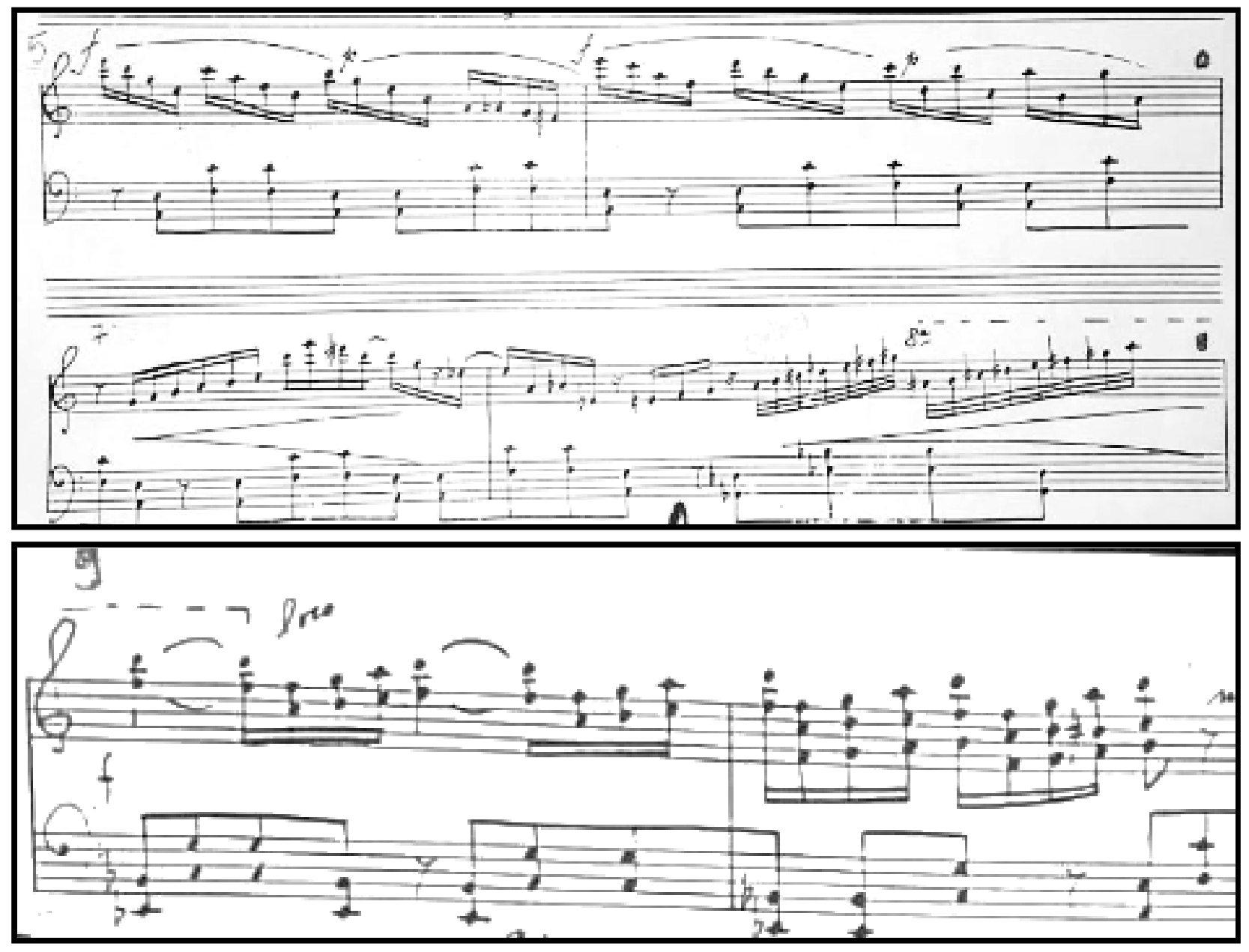

Example 2: Penalva's Piano Sonata no. 2 (1960). Manuscript's 1st movement (moderato), B theme ( $\mathrm{mm}$. 5-10) and transition (mm. 8-10).

There is also a hint of Chopin's style in this material, as shown in Example 3:

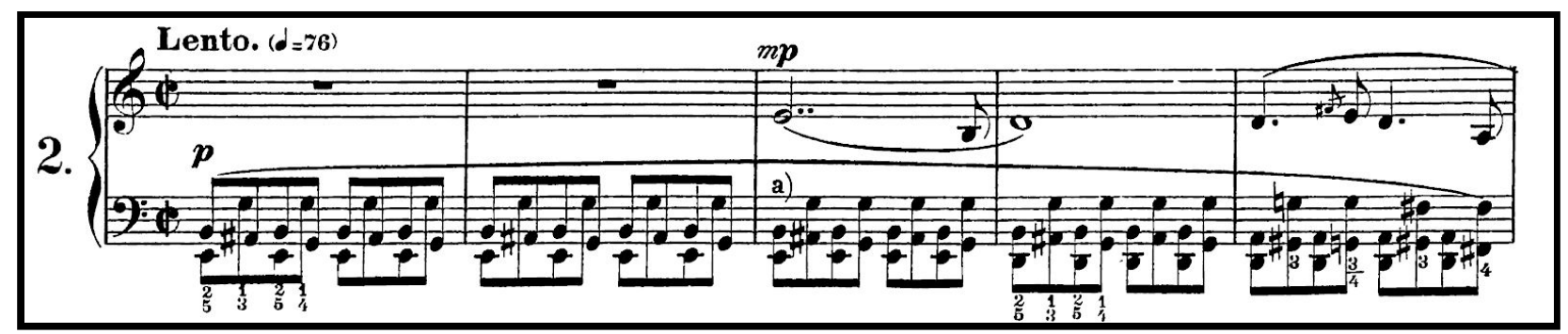

Example 3: F. Chopin's "Preludes op. 28" no. 2, mm. 1-5. 
After a sudden return to A minor (ex. 4, m. 10), section B begins. Section B is a thematic group that can be divided into two main parts as follows: B1 (mm. 10-19) and B2 (mm. 20-27).

Section B1, also in A minor, has a modal theme; but it is more rhythmically expressive and thinner in texture than that of the $\mathbf{A}$ section and its accompaniment chords punctuate the melodic line (ex. 4, mm. 10-17). There is also a striking similarity between $\mathbf{A}$ and $\mathbf{B}$ thematic materials: theme $\mathbf{B} 1$ uses melodic 2 nds and 3rds, and its accompaniment in rhythmic syncopations (ex. 4, mm. 10-17) is clearly derived from theme A's opening material (ex. 1, mm. 1-4). The harmonic sections which occur between the homophonic textures of B1, first in chords of major 7 ths, and afterward in chords of 13ths, suggest a jazzy flavor and confirm Gershwin as an inspiration for this movement (ex. 4, m. 12; m. 14). ${ }^{41}$

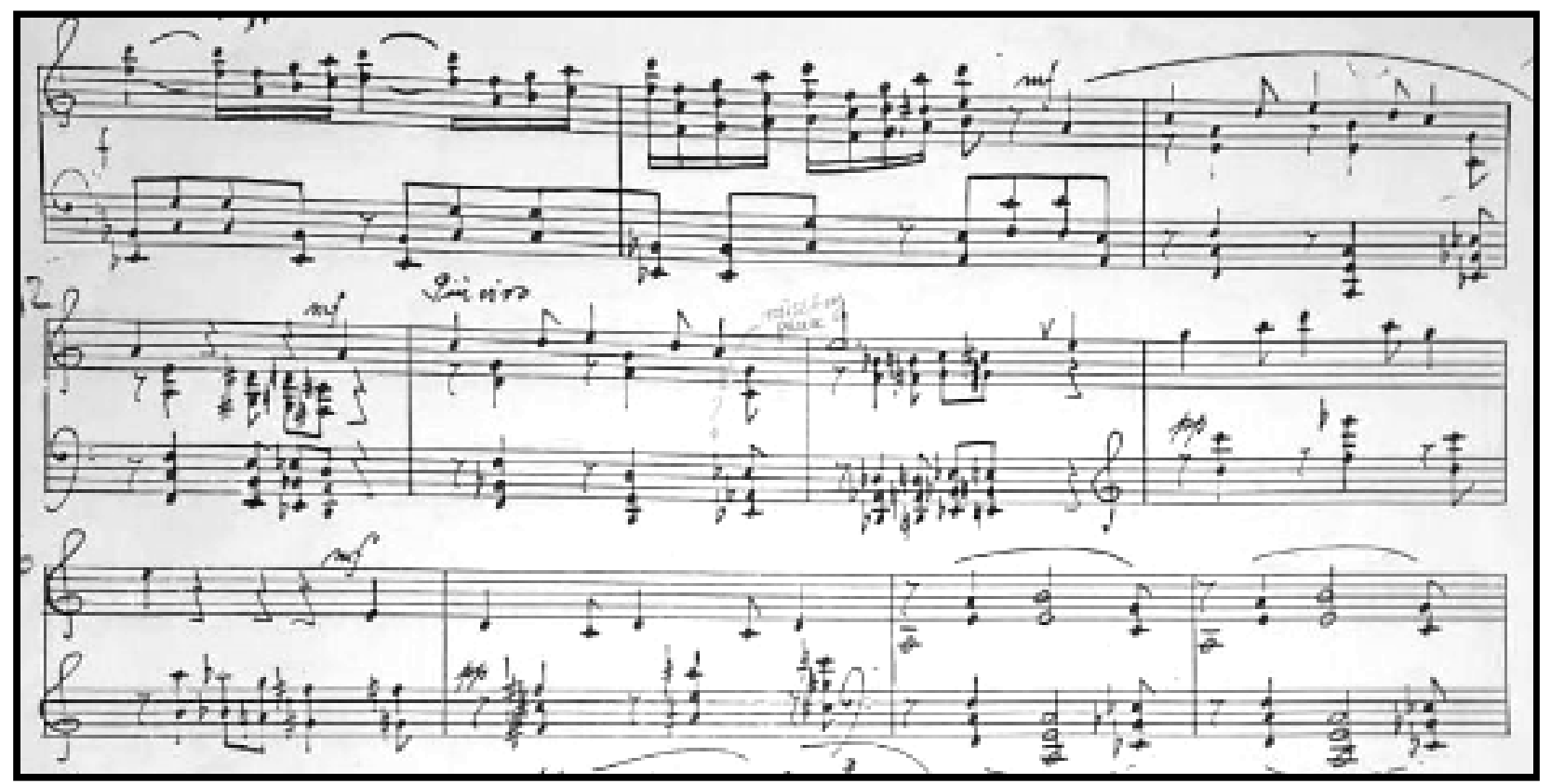

Example 4: Penalva's Piano Sonata no. 2 (1960). Manuscript's 1st movement (moderato), mm. 9-19. B1 theme (mm. 10-17).

${ }^{41}$ Fregoneze, 1992, p. 40. 
Although there is no written indication to resume the original tempo when B1 ends, (ex. 4, mm. 18-19), I assume that the composer has the same intention here as he did at the end of the development (ex. 5, m. 43-46), where, after an accelerando, he indicates that the tempo should resume, "a tpo." (abbreviation for "a tempo"), Coincidently, he uses the same cadential formula he previously employed (ex. 5, m. 46).

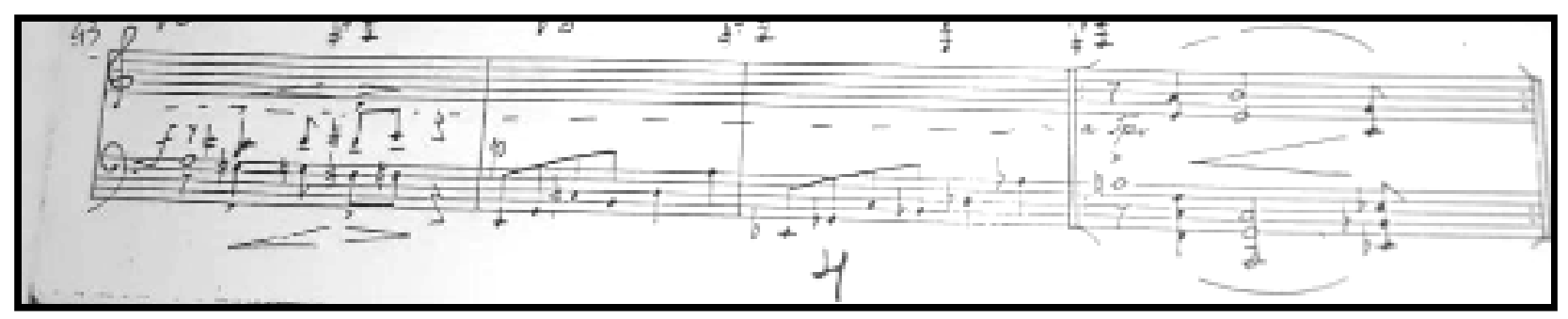

Example 5: Penalva's Piano Sonata no. 2 (1960). Manuscript's 1st movement (moderato), mm. 43-46.

B2 (mm. 20-26), features a melody in the bass voice, contrasting with a treble accompaniment in a quartal chord texture (ex. 6). As indicated, the melody should be projected and cantabile (" $f$ cantando bem" / singing well) with the accompaniment softly played by the right hand in piano and pianissimo (mm. 20-21). Derived from the introduction's material (ex. 1, mm. 1-2), the bassline is accompanied by parallel quartal chords in the treble, in the key of E minor. ${ }^{42}$

As previously stated, quartal harmonies are a stylistic trait of the composer, pervading not only his Sonatas, but also many of his other works.

\footnotetext{
${ }^{42}$ Probably by mistake, in Gonçalves's dissertation, these chords in measure 21 are written differently, in parallel 5ths and 4ths instead (2009, p. 32).
} 


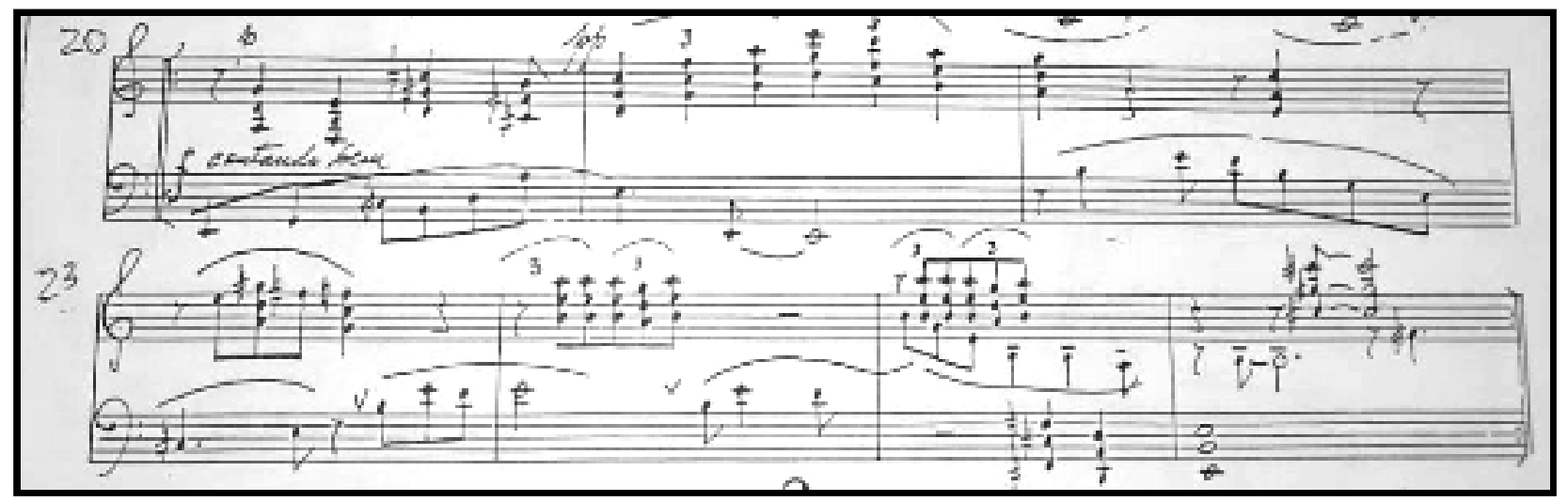

Example 6: Penalva's Piano Sonata no. 2 (1960). Manuscript's 1st movement (moderato), mm. 20-26. B2 theme (mm. 20-26).

The development can also be divided into two sections as follows: First section [D1 (mm. 28-36)], and Second section [D2 (mm. 37-46)].

Section D1 opens with an ostinato derived from the melodic and rhythmic contour of B2 (ex. 7, m. 28), but the rhythm is inverted, as seen in example 6 (m. 20): B2 starts with quarters and eight notes, and D1 (ex. 7, m. 28) with eight notes and quarters instead. The melody of D1 is structured in chords built of 5 ths and octaves, tripling the melodic line, a procedure also employed in Sonata no. 1's development, as we shall see later (ex. 7, mm. 29-36). According to Ellen Thompson, this kind of procedure can potentially be considered as bitonality. ${ }^{43}$ Further, the typical roles of melody and accompaniment are also exchanged in the development section. The melodic contour of $\mathbf{B} 2$ becomes the accompanying texture, and the accompaniment texture of B2 becomes the melodic line in the development (see exs. 6 and 7).

Another exchange of roles occurs in relation to the dynamics. Theme B2 bears the dynamic marking forte, with the direction "cantando bem" (singing well), for its bassline melody, while its accompaniment is marked pianissimo (ex. 6, m. 20-25).

${ }^{43}$ Thompson, Ellen R. Teaching and Understanding Contemporary Piano Music. Kjos West, 1976, p. 115. 
Contrastingly, the development begins with an ostinato (marked pianississimo (ppp)) and a melody (marked forte $(f)$ ), with the direction "cantando bem" (singing well) (exs. 6 and 7).

During the development, Penalva explores many thematic materials from the exposition, for example, elaborating on the 6th and 7th chords from the opening theme. The structure of the 6 th and 7 th chords is also seen in the melodic line of the ostinato (ex. 7, mm. 28-36; ex. 1, mm. 1-4) and further, the 2 nd and 3rd intervals of the opening theme melodic line are elaborated in the melody of D1 (ex. 7, mm. 29-31; ex. 1, mm. 1-4. Parallelisms from the end of theme A2 (ex. 4, m. 10) are found in the parallel melodic chords of 5ths and octaves in the melodic line of D1 as well (ex. 7, mm. 32-33).

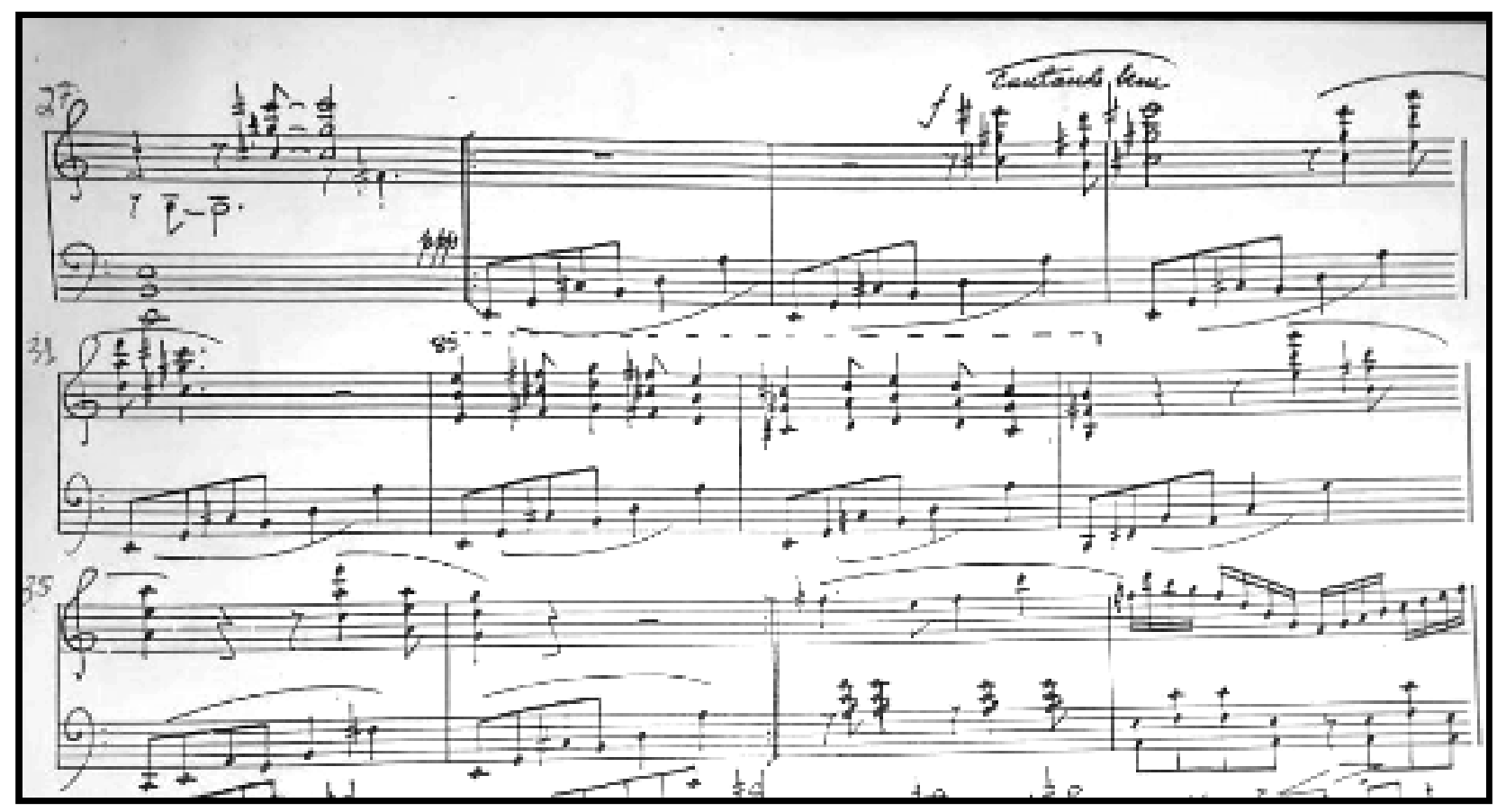

Example 7: Penalva's Piano Sonata no. 2 (1960). Manuscript's 1st movement (moderato), mm. 27-38. Development's first section D1 (mm. 28-36).

In section D2, Penalva blends even more of his compositional materials (ex. 8, $\mathrm{mm} .37-45)$. First, the melodic line resembles ideas from both $\mathbf{A} 1$ and $\mathbf{A 2}$, using the initial motif's interval of a 2nd (ex. 8, mm. 37-38). In the following measures 39-41 (ex. 
8 ), he continues to elaborate on the initial interval of a 2 nd, as well as upon the major 6th chords of the cadential formula at the end of B2 (ex. 6, m. 26).

In measures 42-43, Penalva simultaneously employs jazzy ascending and descending chromatic chords, taken from B1, (ex. 4, mm. 12 and 14), by using mirrored writing (ex. 8, mm. 42-43). The final developmental measures (ex. 8, mm. 44-45), present accompaniment material from B2, initially in the same key of E minor and then altered chromatically by a half step. This accompaniment material leads to the same cadential formula that completed B1 (ex. 4, mm. 18-19).

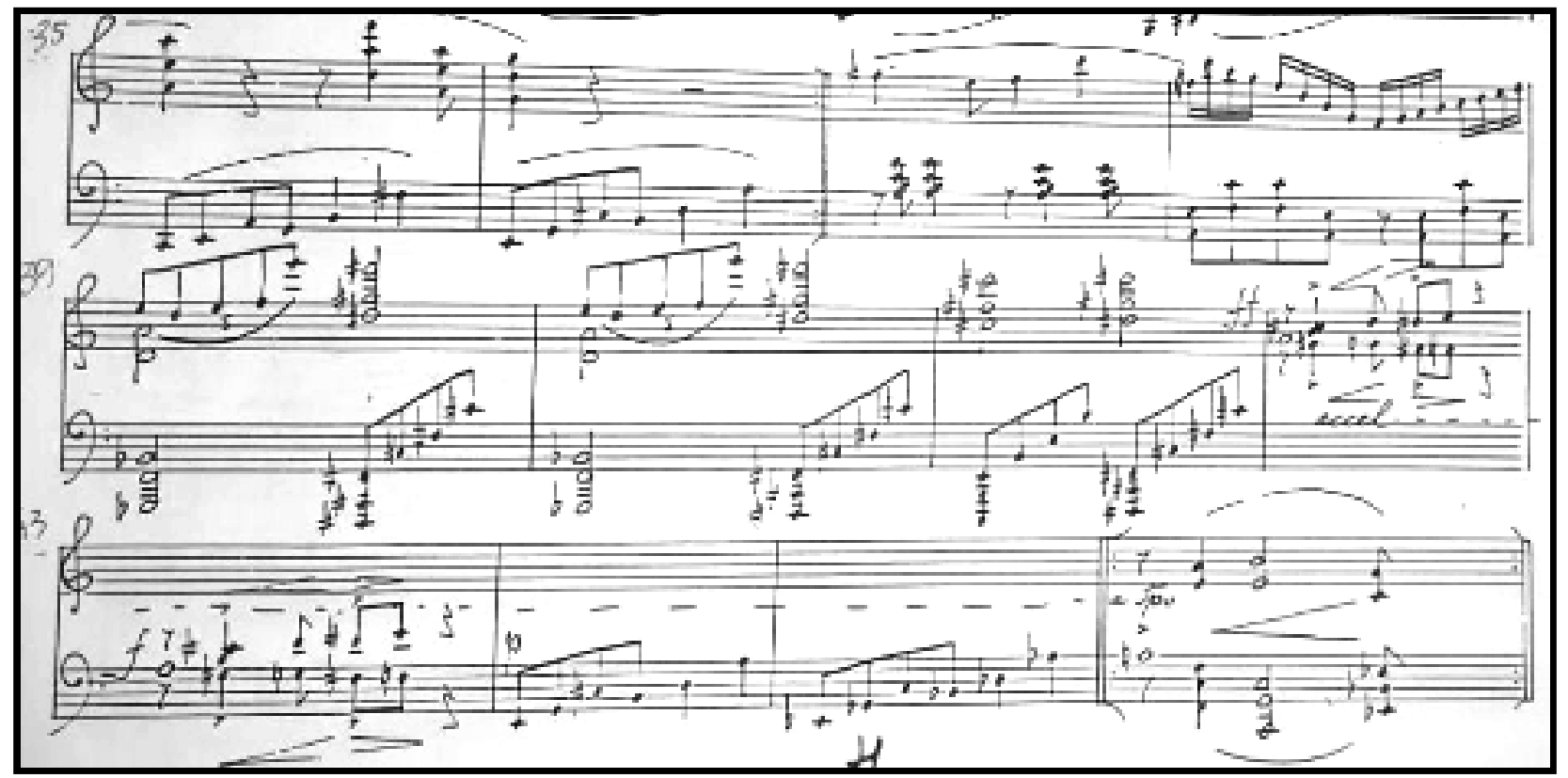

Example 8: Penalva's Piano Sonata no. 2 (1960). Manuscript's 1st movement (moderato), mm. 35-46. Development's second section D2 (mm. 37-45).

The recapitulation that follows presents both themes $\mathbf{A}$ and $\mathbf{B}$ once again. They are literally re-exposed without any modifications (mm. 47-72). As traditional for the classical sonata form, B2 now appears in the home key of A minor, instead of in the dominant key of $E$, as it was in the exposition (ex. 9, mm. 66-72). An unstable emphasis on the major chord of $A 6(9)$ in the coda (ex. 9, m. 73-75), colored briefly by a minor 6 th 
chord in measure 73 , seems to remind us of that prominent minor mode of this movement.

Despite the change of tempo via the marking ritenuto and the dynamic decrescendo to $p p$ and $p p p$, the coda (ex. 9, mm. 73-75) presents the same basic harmony as the cadential formula of B2 (ex. 6, m. 26). This time, though, it appears in the home key of A major instead of E major. Thus, the only essential difference between this coda and that of B2 is that the A-minor chord includes a minor 6 th $^{44}$ in measure 73 , while the rest remains the same (ex. 9, mm. 73-75).

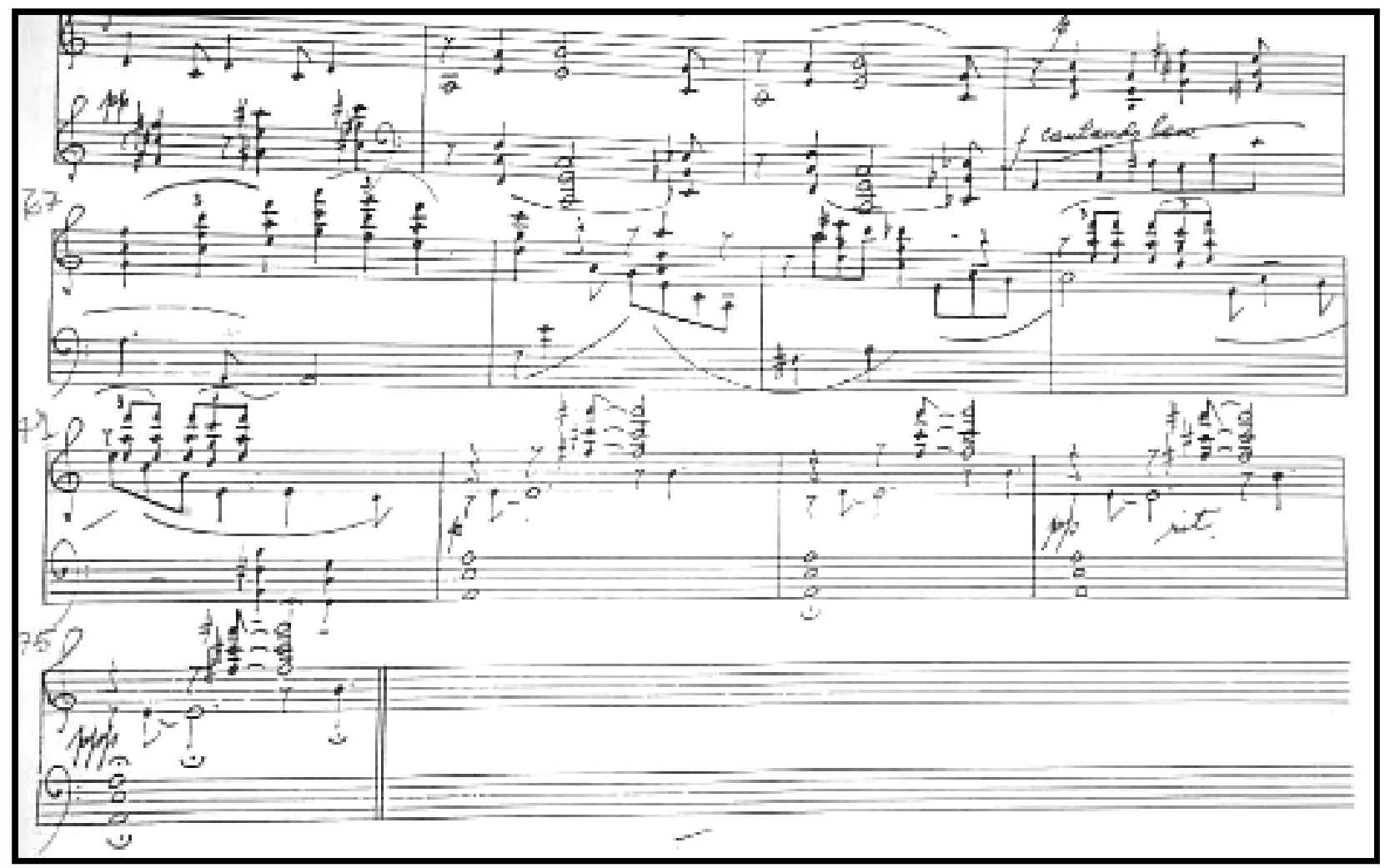

Example 9: Penalva's Piano Sonata no. 2 (1960). Manuscript's 1st movement (moderato), mm. 63-75.

${ }^{44}$ Differing from the manuscripts and from Gonçalves's version, in Dottori's edition (2011, p. 12, m. 74) the 6th and 3rd major intervals in the right hand are probably a writing mistake. 


\section{Andante cantabile}

\section{$A-B$ - $A^{\prime}$}

A [ Intro (1-2) A1 (mm. 3-6) - A2 (mm. 7-9) ]

Transition 1: (mm. 10-18)

B [ B1( mm. 19-26) - B2 (27-33)] B1': (mm. 34-40)

Transition 2: (mm. 41-48)

\section{A' [Intro (1-2) A1 (mm. 3-6) - A2 (7-9) Coda (10-13)]}

Structured in ternary form (A-B-A'), the second movement of the Sonata no. 2 is very different from the outer movements, which are fast and energetic. Its home tonality is $\mathrm{D}$ minor and the second section appears in the minor dominant key of $\mathrm{A}$ minor. The atmosphere of this movement is mostly introspective, expressive, and melancholic. As overtly stated by Penalva, he had Guarnieri's style in mind when composing this movement. Although none of Guarnieri's work is directly quoted, several of his compositional traits are present, particularly from his pianistic repertoire, such as the style found in his series of " 50 Ponteios" ${ }^{45}$ for solo piano. The irregular meter of $7 / 8,{ }^{46}$ its freely structured inner melodies (ex. 1, mm. 3-9), and its dense, syncopated chordal texture (ex. 2, mm. 41-48), are representative examples of Guarnieri's musical style in this sonata.

45 "50 Ponteios" for solo piano, Guarnieri, C.. Ricordi SRE-8. https://www. youtube. com/watch? $v=8 X s G$ 4j lleU

${ }^{46}$ Although the manuscript's time signature is $7 / 4$, it is misconceived, with $7 / 8$ being correct. 


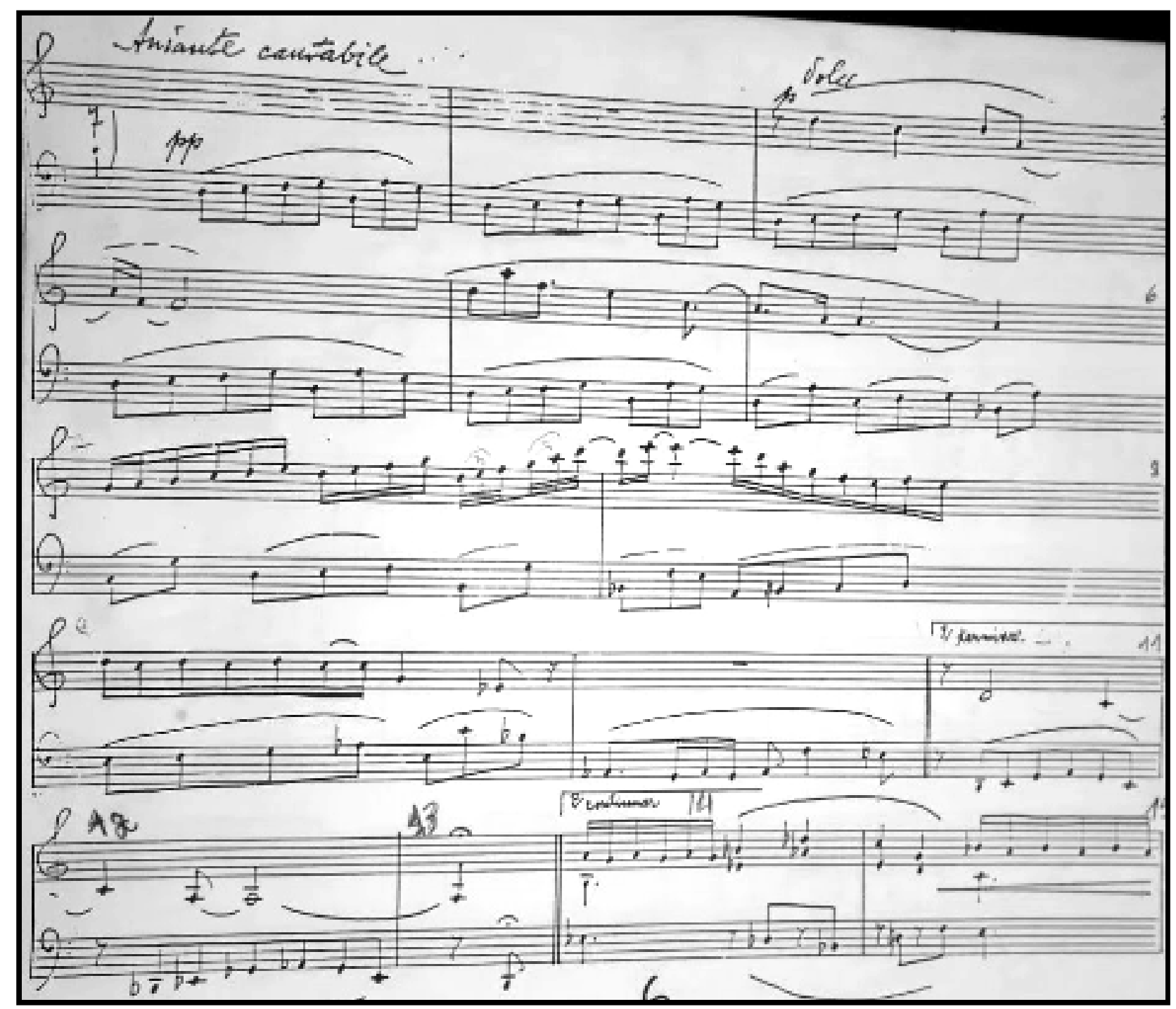

Example 1: Penalva's Piano Sonata no. 2 (1960). Manuscript's 2nd movement (Andante cantabile), mm. 1-11. 


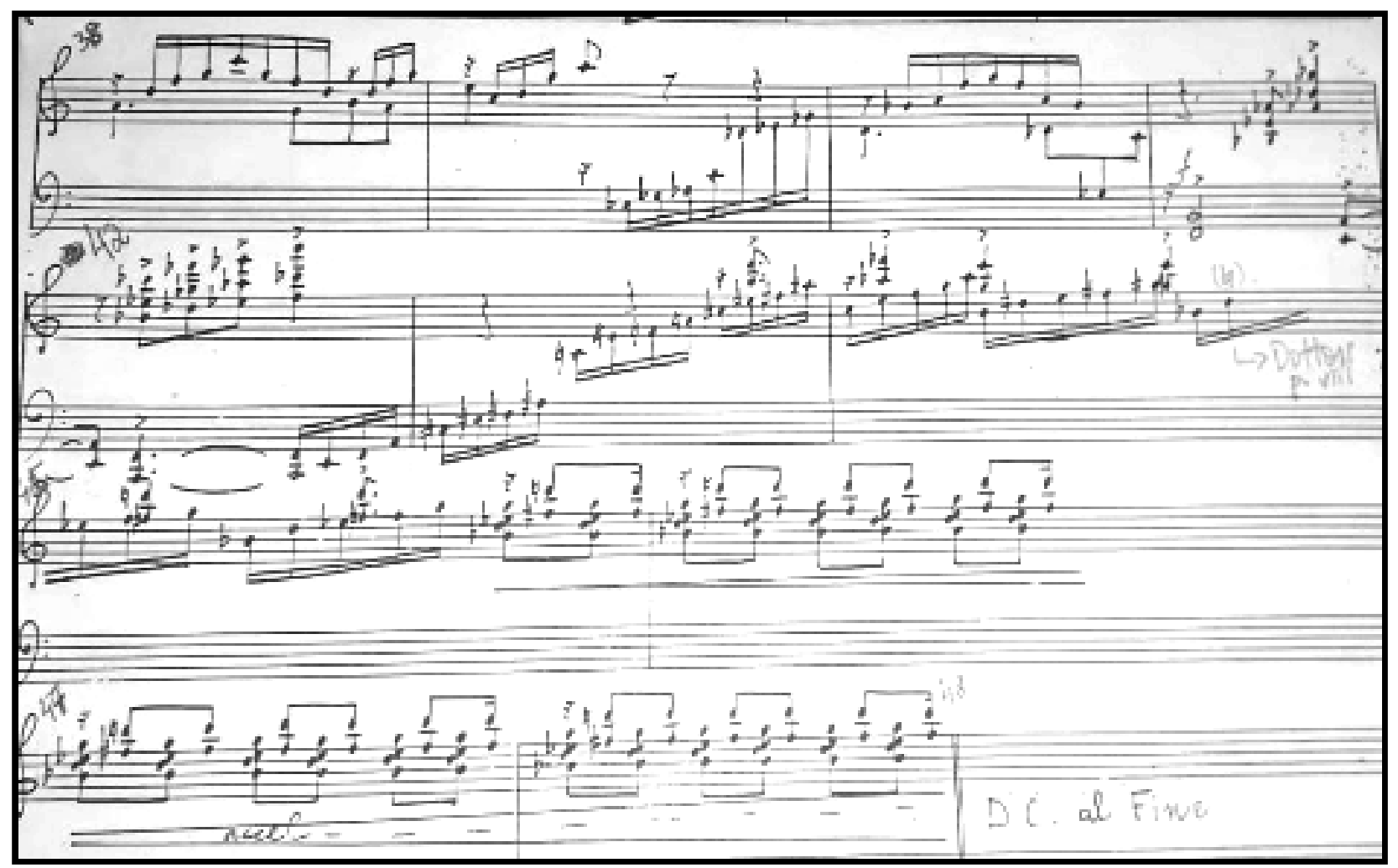

Example 2: Penalva's Piano Sonata no. 2 (1960). Manuscript's 2nd movement (Andante cantabile), mm. 38-48.

The Andante cantabile begins with an ostinato in the left hand, inherited from the first movement's development (3.1.2, "Moderato", ex. 7). Above the ostinato, Penalva overlays an expressive, modal theme $\mathbf{A}$ with the direction dolce (ex. 1). Theme $\mathbf{A}$ can be divided into two parts: $\mathbf{A 1}, \mathrm{mm} .3-6$, and $\mathbf{A 2}, \mathrm{mm} .7-9$ (ex. 1). As corroborated by Gonçalves (2009, p. 37), Section A1 is characterized by a nostalgic atmosphere inherent both in the Brazilian seresta ${ }^{47}$ and in Guarnieri's music. ${ }^{48}$ There are many striking seresta features here: the rounded melodic lines over the tonic D-minor triad,

${ }^{47}$ Seresta (serenade) was a name that emerged during the 20th century in Brazil to describe the oldest tradition of popular singing in cities: the serenade. Featuring songs of a sentimental character sung at night in the streets, with a mandatory stop in front of the girlfriend's house, the serenade had already been described in 1505 in Portugal by Gil Vicente. In Brazil, the custom of serenades would be mentioned by the French traveler Le Gentil de la Barbinais, passing through Salvador in 1717, when telling in his book Nouveau voyage autour du monde that "at night only the sad chords of violas were heard," played by Portuguese people (swords hidden under their nightgowns) walking "under the balconies of their loved ones" and singing, instrument in hand, with "a ridiculously tender voice."

${ }^{48}$ C. Guarnieri, Ponteios n. 22, n. 31, and n. 44. 
the ostinato as accompaniment, the flexible rhythmic structure - all this reflects the Brazilian genre's characteristic atmosphere (ex. 1, mm. 1-9). The lyric character of the Brazilian seresta (serenade) is also explored via Sonata no. 1 (1970).

Section A2 (mm. 7-9) is prepared by changing rhythmic patterns and chromatic passing notes in the bass line at the end of $\mathbf{A} 1$ (ex. 1, m. 6). A2 first presents an ascending, sinuous, diatonic scale, and afterward, a descending and rhythmically stark melody, culminating in the low register of the piano with no accompaniment (ex. 1, mm. $7-10)$.

As also noted by Fregoneze, the rhythmic pattern in the accompaniment of A2 contrasts significantly to that of A1 as follows: $2+3+2$ (ex. 1, m. 6), 2+3+2 (m. 7), 3+4 (m. 8) and 4+3 (m. 9) (1992, p. 46). A melodic line in the bass (ex. 1, m. 10) prepares the transition to section B. (ex. 3, mm. 10-18).

This transition section utilizes several motives from $A 1$ (ex. 1, 1-6) and A2 (ex. 1, mm. 7-10). The flowing semiquaver seconds in measure 9 seem to anticipate the transition's main motif (ex. 1, m. 1, m. 9), which, in turn, comes from the first three melodic notes of A1 (ex. 1, m. 2). The transition's second melodic motif in 4ths (ex. 3, m. 14 , beats 3 and 4 ) is similar in contour to that of the second part of A1, D4-A4-F4-E4 (ex. 1, m. 5). The second motif of the transition becomes its focus, composed with varied rhythmic combinations in patterns of $3+4$ and $4+3$, near the end of the transition, in measure 17 (ex. 3, mm. 15-17). 

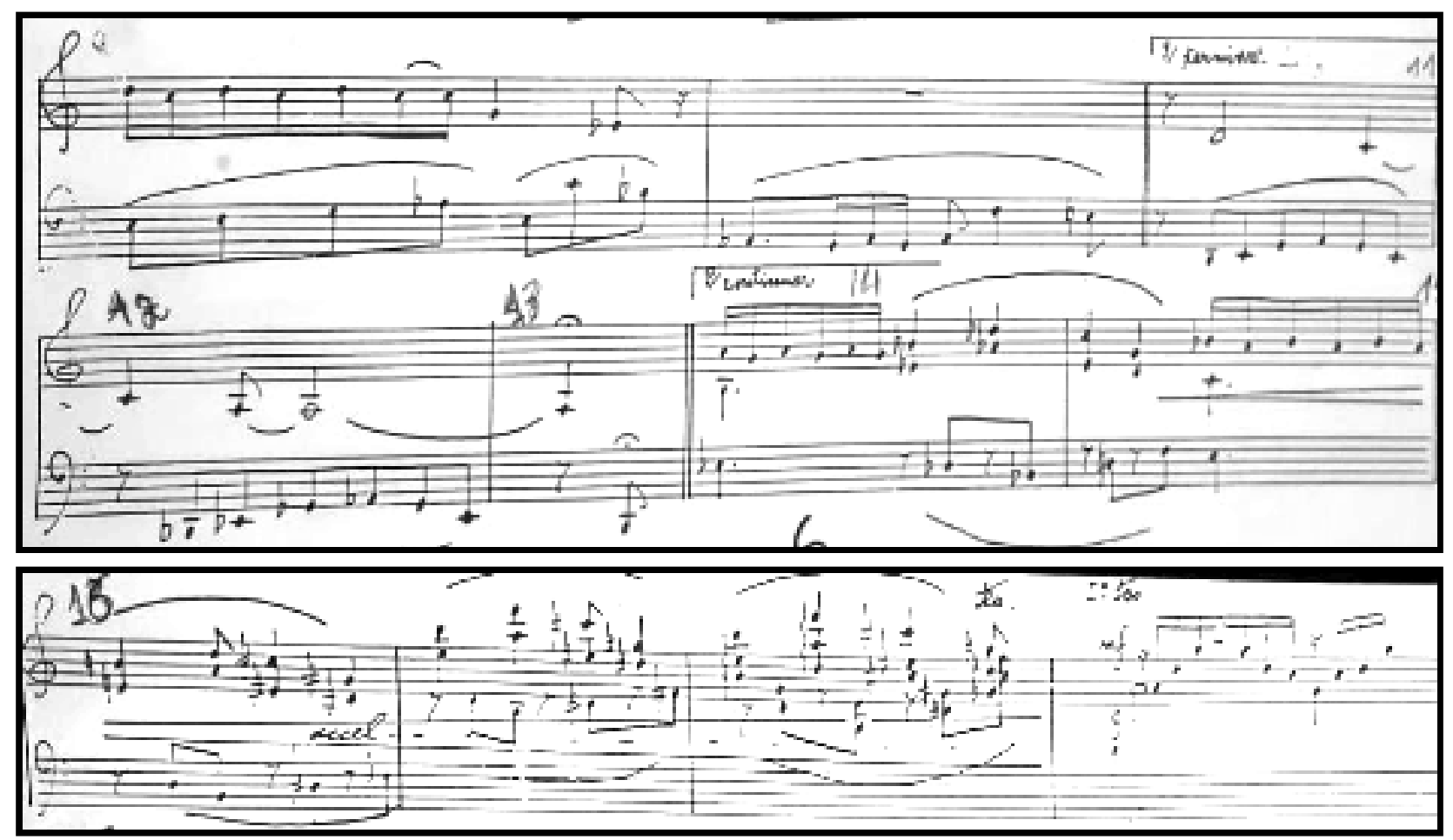

Example 3: Penalva's Piano Sonata no. 2 (1960). Manuscript's 2nd movement (andante cantabile), mm. 9-19 (transition to B section).

The B section presents two contrasting themes, B1 (ex. 4, mm. 19-26) and B2, (ex.4, mm. 27-33). Section B1 is more expressive. Its melody is accompanied by a dense and fluid accompaniment which alternates between the use of 4ths and stepwise motion, resulting in an impressionistic atmosphere (mm. 16-23). Gonçalves emphasizes that, in this section, Penalva leaves the employment of pedal and articulation up to the performer, who may use both in order to create this atmosphere (Gonçalves, 2009, p. 39). Therefore, although not indicated by Penalva, it is advisable to employ pedaling in section B1, due to its impressionistic nature. ${ }^{49}$ Note that, apart from some directions in Sonata no. 1, there are no pedal indications in Sonata no. 2 or Sonata no. 3.

\footnotetext{
${ }^{49}$ Similar piano writing can be found in many works of composers such as Ravel, Debussy, Fauré, Erik Satie, and Manuel De Falla, among others.
} 


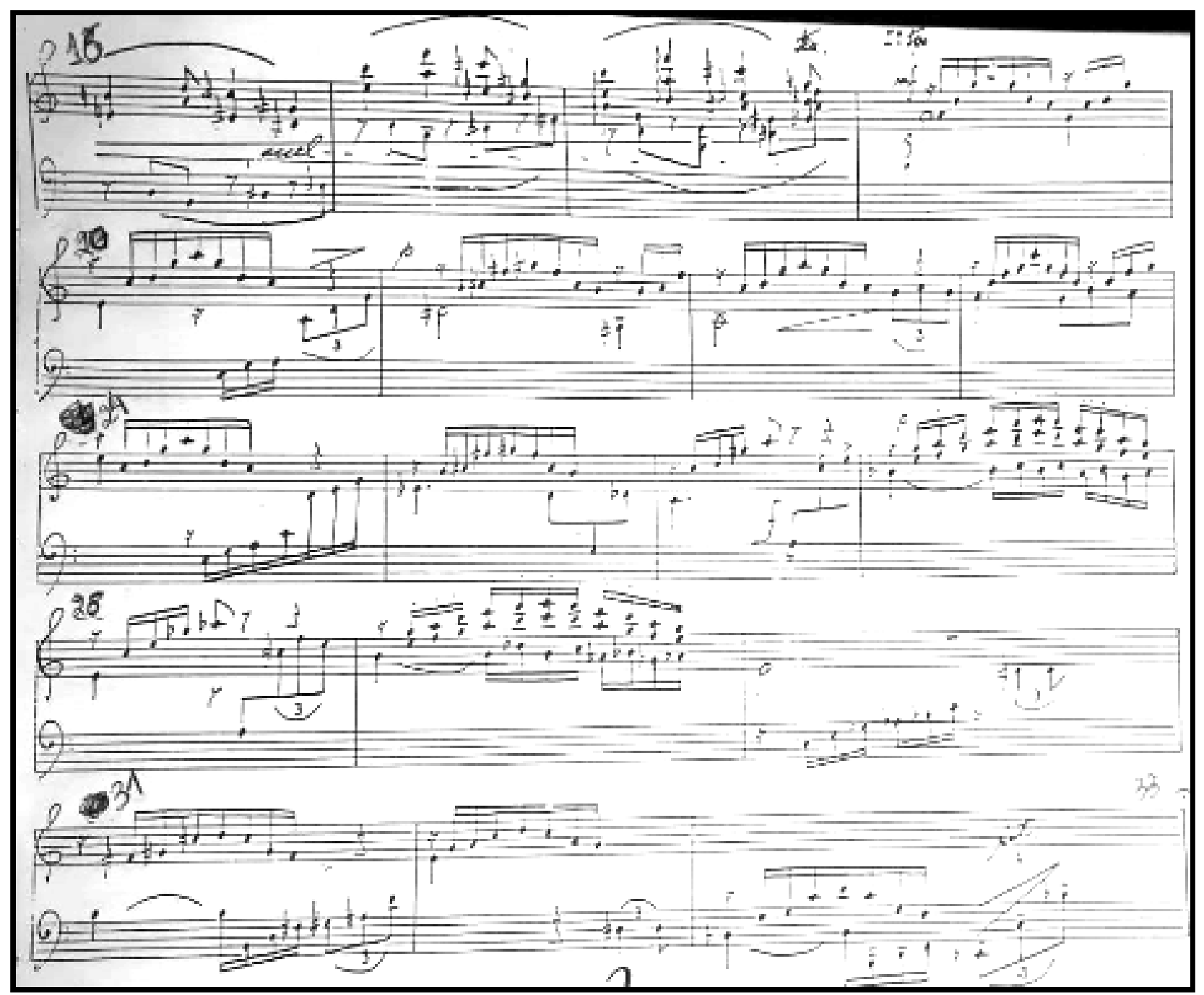

Example 4: Penalva's Piano Sonata no. 2 (1960). Manuscript's 2nd movement (andante cantabile), mm. 16-33 (B section).

The melody of B1 appears over A-minor pentatonic material, mainly in the lower register of the piano. This is accompanied by a fluid sixteenth-note texture which occasionally changes harmony abruptly, but quickly returns to the key of A minor (ex. 4, $\mathrm{mm} .18-25)$. The density of this wonderful accompaniment obscures the separation between melody and harmony, giving this passage more fluidity and flexibility than the previous ones. 
B2 theme (ex. 4, mm. 26-33) has a contrapuntal texture with a sinuous melody in the bass line accompanied by a scale in thirds, marked staccato. It is highly contrasting to theme B1. The legato scale in the left hand must be kept connected, while a restrained employment of pedal may aid in realizing the scale of staccato thirds in the right hand. The contrasting forte and piano dynamic markings Penalva indicates at the start of B2 should logically be employed in the parallel place in the second part of B2, even though the latter markings are not indicated (ex. 4, mm. 28-29). ${ }^{50}$

Following this, the B1 theme resumes in ( $\mathrm{mm} .34-40)$ with a sudden harmonic change in measures 39-40, leading to a second dramatic transition (ex. 5, mm. 41-48). The left-hand 4ths and right-hand quartal harmonies are more related to the material of the first movement than to that of the second movement (ex. 5, mm. 41-42). For instance, in the Moderato we observe the melodic 4ths of A2 and the quartal chords in the accompaniment of B2 (ex. 6, mm. 9 and 20, respectively). In measures $43-45$, Penalva uses interesting musical elaboration. Beginning with ascending arpeggios in the low register of the piano, built from second inversion F\#M7 and FM7 chords, (ex. 5, mm. 43-44) he next replaces the arpeggios with contrasting stepwise, descending, chromatic figures over the chords $\mathrm{C} 6, \mathrm{~B} 6$, and $\mathrm{Bb} 6$. These chords lead to a bitonal tremolo of Bb6 and B chords (ex. 5, mm. 44-46). It is interesting to observe that, in measures 44 and 45, the chromatic chords in arpeggio are now grouped in five notes per beat instead of the previous expected four, which leads to a metric instability (ex. 5 . mm. 44-45). Along with this, chromatically descending 4ths are added in a higher

${ }^{50}$ Dottori's edition (2011, p. 14, m. 23-26) as well as Gonçalves' dissertation (2009, p. 40, figura 14) both keep the original manuscript's writing with no additional dynamic markings for this passage. 
register of the piano, written in quarter notes. This adds to the rhythmic instability of the transition (ex. 5, mm. 43-45).

The transition leads to an exact presentation of A1 in its entirety, ending with a brief and thin-textured coda. It culminates in the interval of a 5th, an open and ancient harmony, perhaps reminiscent of Penalva's background in Gregorian chant and renaissance styles (ex. 7, mm. 11-13).

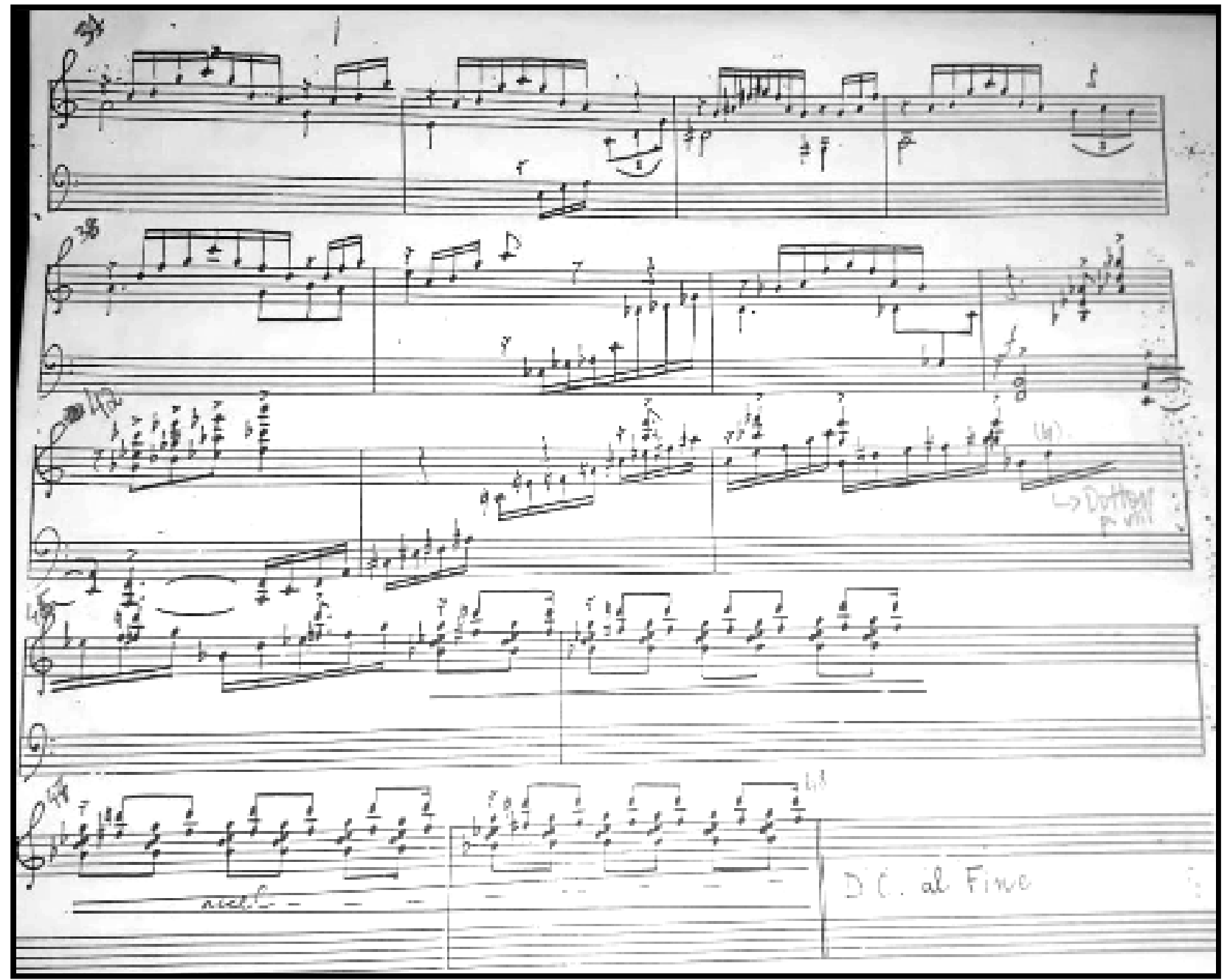

Example 5: Penalva's Piano Sonata no. 2 (1960). Manuscript's 2nd movement (andante cantabile), mm. 34-48 (A' section). 


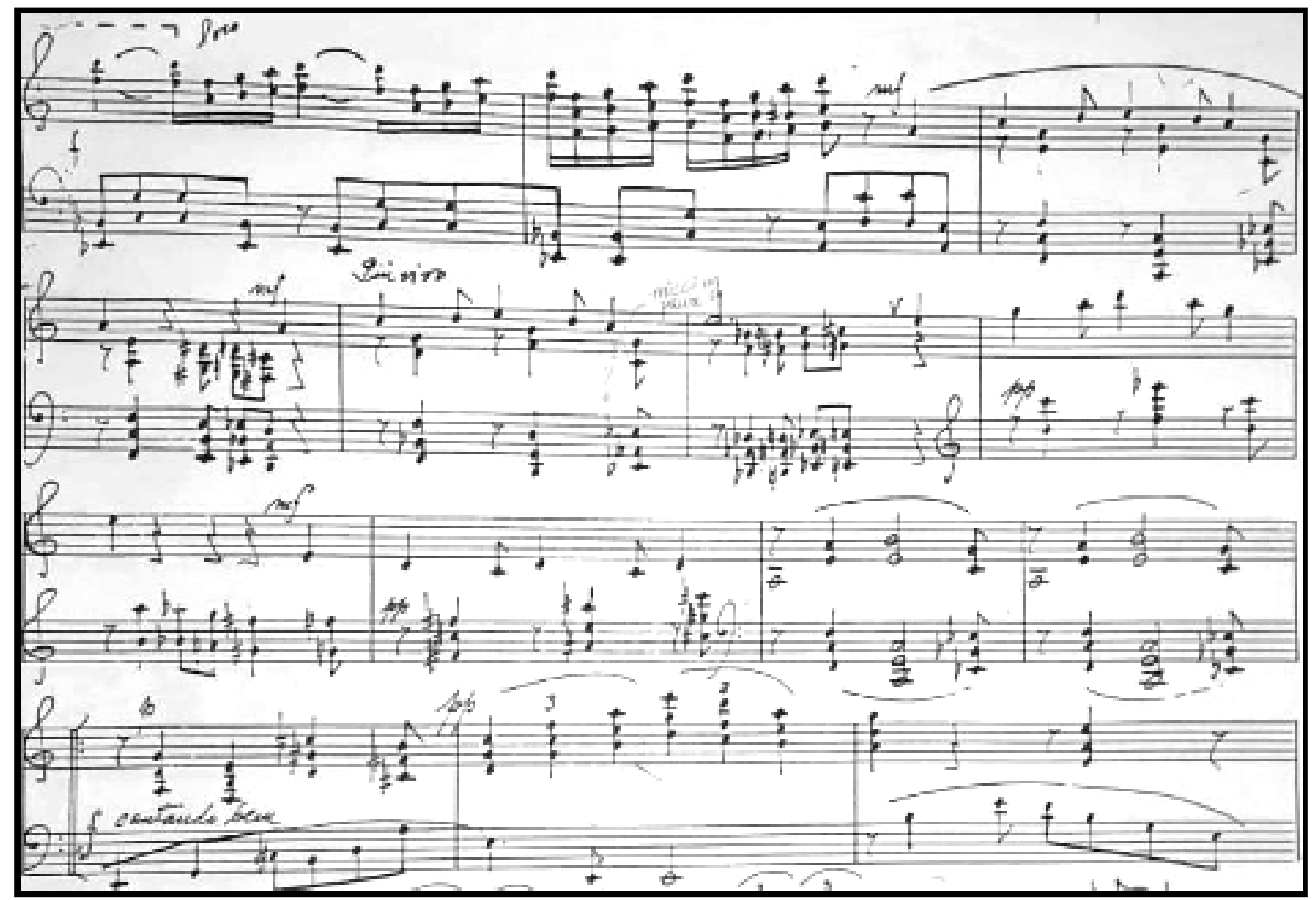

Example 6: Penalva's Piano Sonata no. 2 (1960). Manuscript's 2nd movement (andante cantabile), mm. 9-26.

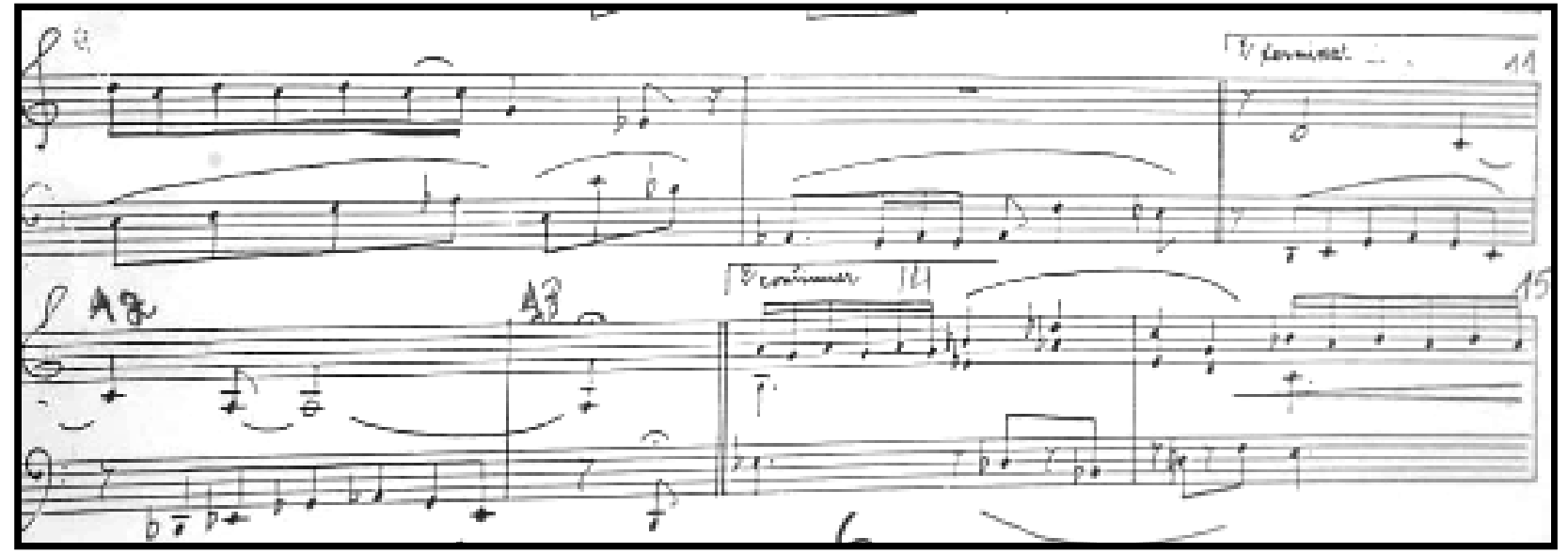

Example 7: Penalva's Piano Sonata no. 2 (1960). Manuscript's 2nd movement (andante cantabile), mm. 11-13). 


\section{Rondó Allegro}

\section{A-B-A-C-A-D-A (coda)}
A $[(\mathbf{A} 1(\mathrm{~mm} .1-3)$ - A2 (mm. 4-9)]
B [(B1 (mm.10-22) - B2 (mm. 23-35) - B1' (mm. 35-41) - Transition (42-47)]
C $[(\mathbf{C} 1(\mathrm{~mm} .58-67)$ - C2 (mm. 68-86)]
D [(D1 (mm. 97-104) - D2 105-107) - D1' (mm. 107-117)

Coda: $(\mathrm{mm} .117-130)$

This movement is structured like a classical rondo in the form shown in the outline [(A-B-A-C-A-D-A (coda)]. According to the composer, this movement is inspired by Webern's style (Penalva as cited in Fregoneze, 1992, p. 40).

Given the character, "irritado" (annoyed), ${ }^{51}$ theme $\mathbf{A}$ is energetic. It can also be divided into two parts. Part A1 is comprised of powerful octaves (ex. 1, mm. 1-3), followed by part A2, written in percussive, mirrored polychords (ex. 1, mm. 4-9).

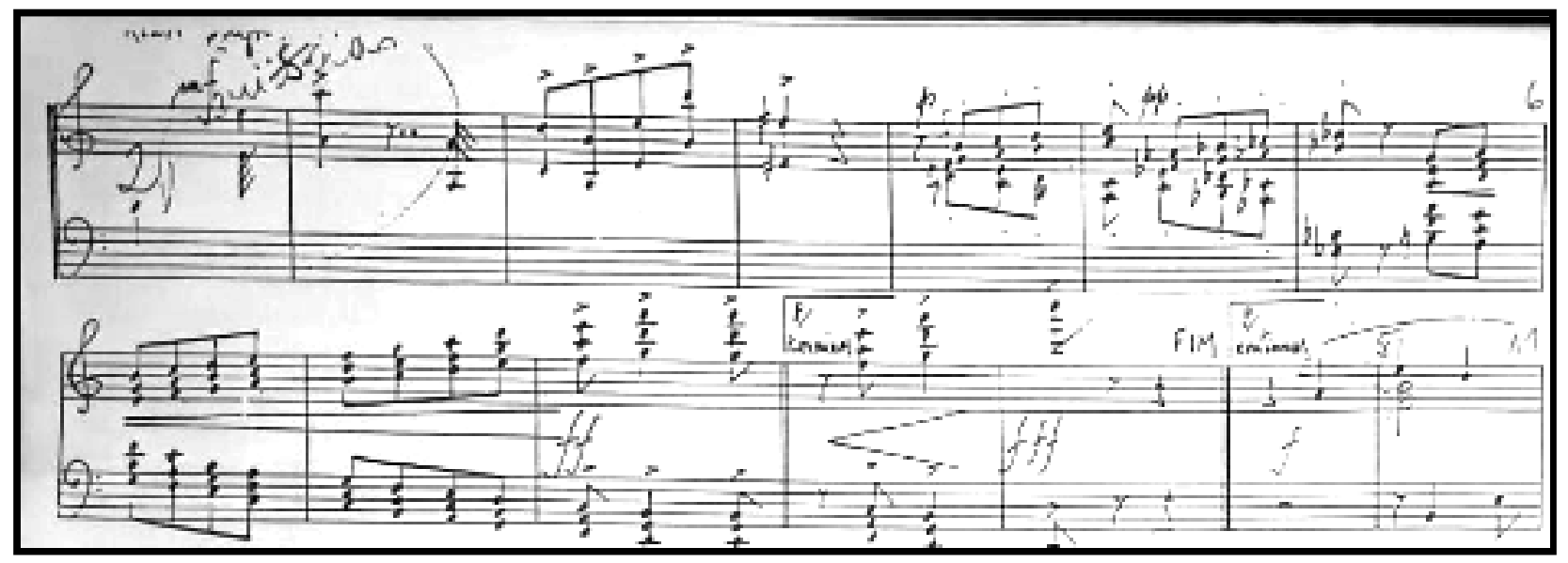

Example 1: Penalva's Piano Sonata no. 2 (1960). Manuscript's 3rd movement (rondó allegro), mm. 1-11.

\footnotetext{
${ }^{51}$ Although it does not appear in Dottori's edition (2011, p. 16), the indication "irritado" is present in the manuscript. It is also corroborated in Gonçalves' dissertation (2009, p. 43).
} 
The following section B (mm. 10-47) is much larger, and it can be divided into four subsections: B1 (mm.10-22); B2 (mm. 23-35); B1' (mm. 35-41); and Transition (42-47).

Subsection B1 is a modal theme, starting with a resemblance to theme A's first motif. It is accompanied by chords built of 4 ths and 5 ths that are superimposed upon the theme (ex. 2, mm. 10-21). Subsection B2 contrasts with B1, yet it also employs quartal material in both its melody and its accompaniment. By spacing the scoring between two hands as well as employing a more static quartal harmony in the accompaniment and a more punctuated melodic line, Penalva achieves a varied texture despite using similar materials between these two sections. Subsection B2 contains a bitonal texture split in both hands such that the left hand is playing in A major and the right hand in Bb-minor pentatonic (ex. 3. mm. 22-35).

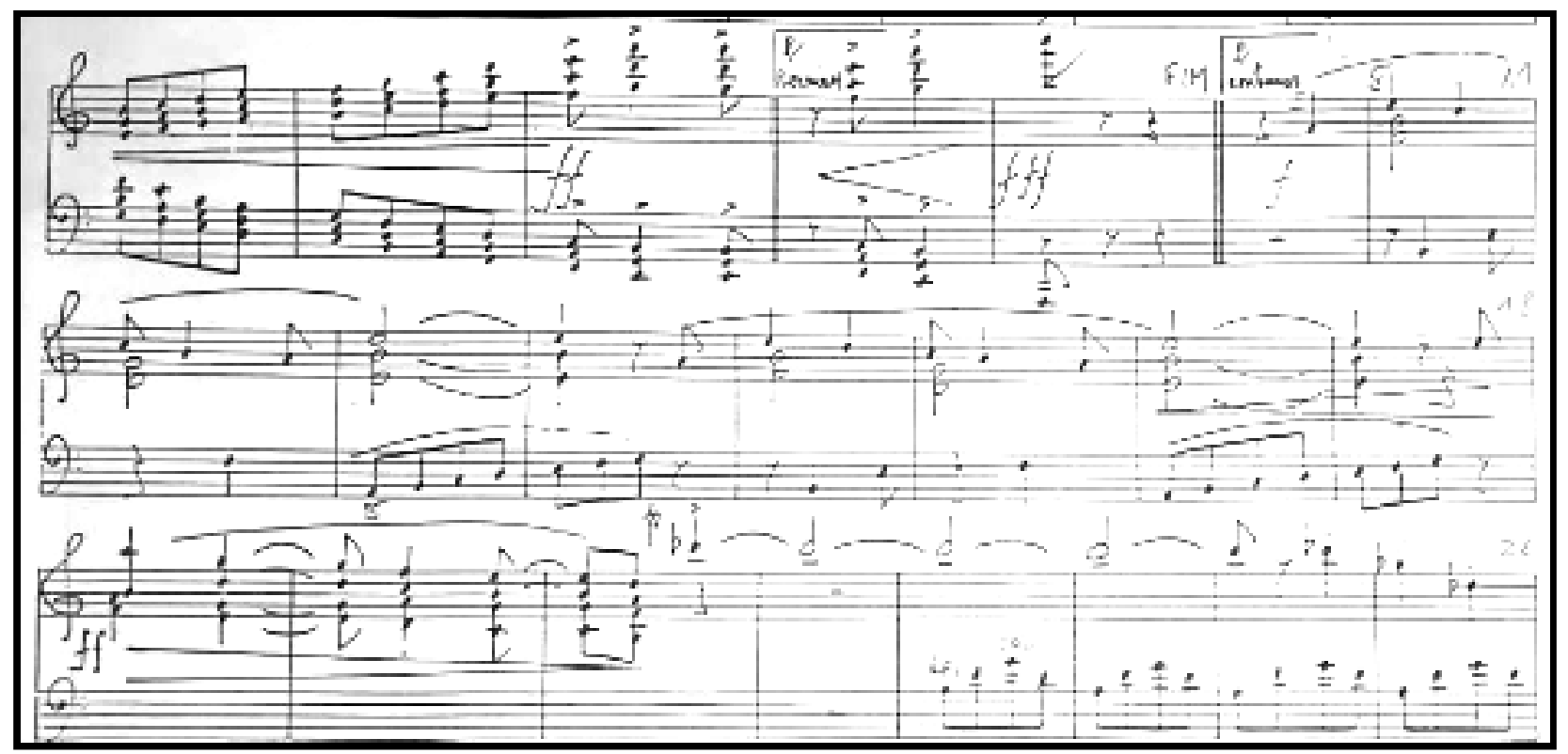

Example 2: Penalva's Piano Sonata no. 2 (1960). Manuscript's 3rd movement (rondó allegro), mm. 7-26. B1 subsection (mm. 10-21). 
The melody of B2 becomes shortened and more syncopated as it nears subsection B3 in measures 35-36. Measure 29 encapsulates the syncopation, which continues into measure 32 . The size of the melodic intervals continues to increase, along with the overall musical tension, into subsection B3 (ex. 3, mm. 29-35).

Subsection B3 starts with the anacrusis into measure 36 . The very beginning of the melody of B3 is the same as the melody of B1 (ex. 2, mm. 10-21); however, the melody of B3 is fully harmonized, unlike that of B1, and its bass is doubled in octaves (ex. 3, mm. 36-39).
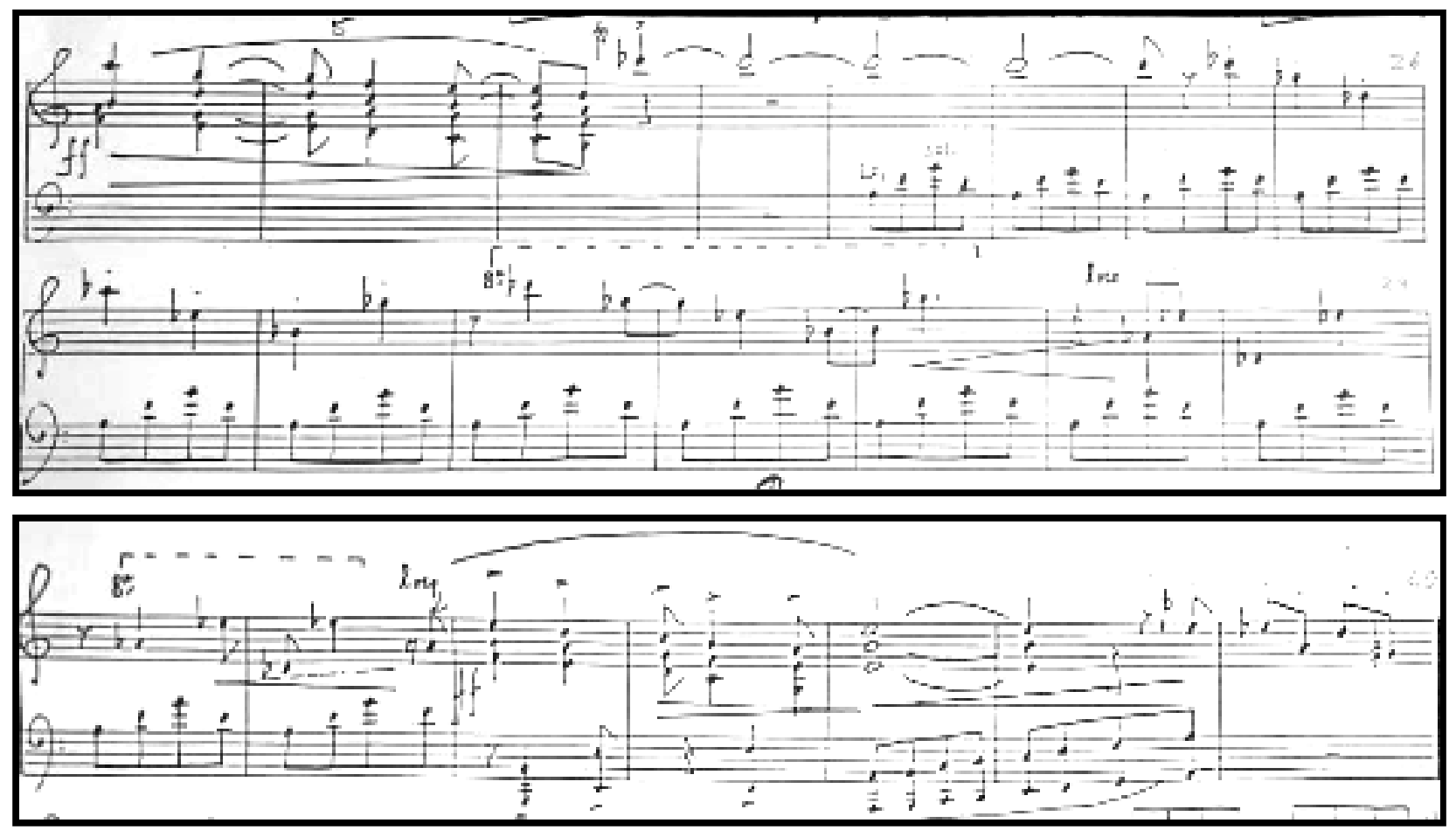

Example 3: Penalva's Piano Sonata no. 2 (1960). Manuscript's 3rd movement (rondó allegro), mm. 19-40. B2 subsection (mm. 22-35).

The second part of B3 is built using 4ths, once again. After a brief descending melodic line in tritones (ex. 4, mm. 39-40), an increasingly ascending harmonic progression in 4ths and 5ths acts as a transition to the recapitulation of $A$ (ex. $4, \mathrm{~mm}$. 42-47). 


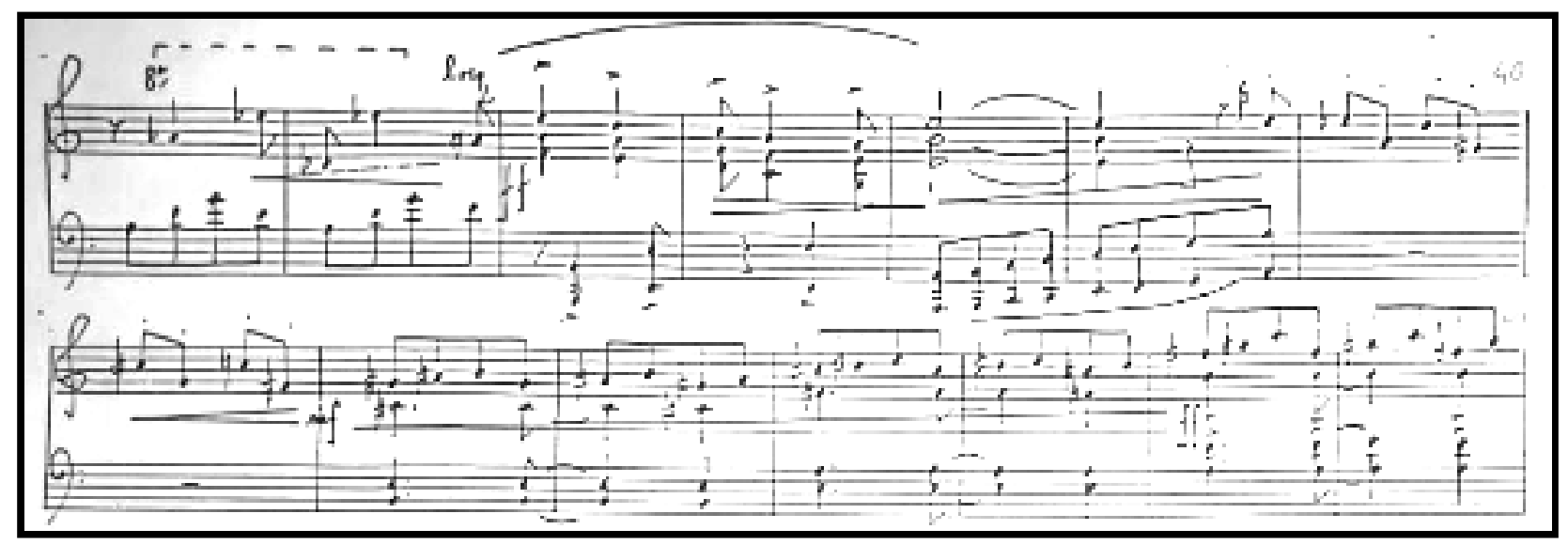

Example 4: Penalva's Piano Sonata no. 2 (1960). Manuscript's 3rd movement (rondó allegro), mm. 34-47. B3 subsection ( $\mathrm{mm}$. 35-47).

If one thinks in two-measure units, the resultant rhythm of this passage resembles many common Brazilian rhythms, like those found in "baião,"52 for instance. It is also employed in the third movement of Penalva's Sonata no. 3, the agitato rondó (ex. 5).

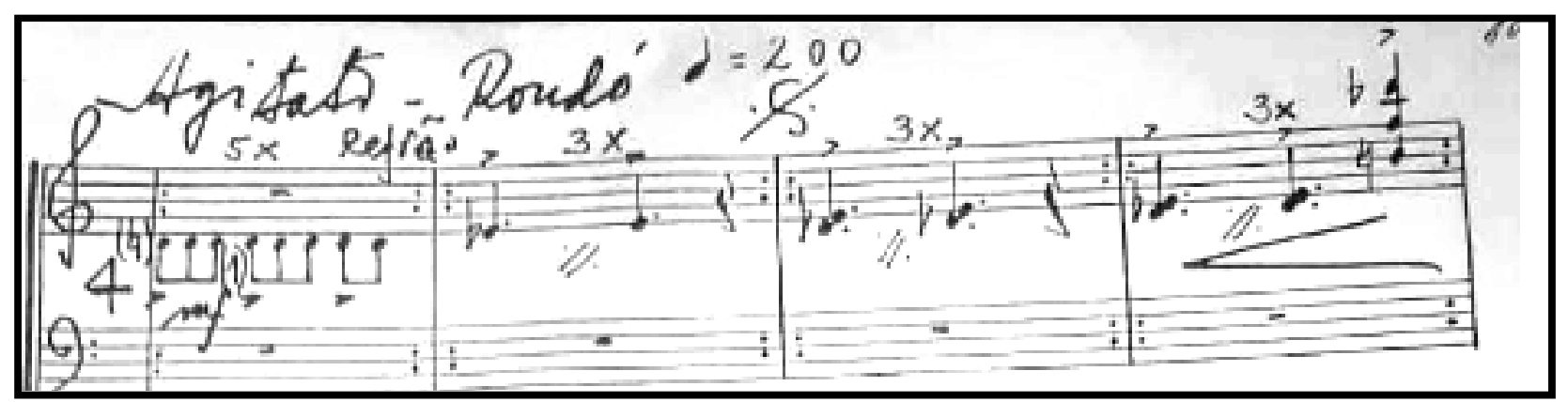

Example 5: Penalva's Piano Sonata no. 3 (1991). Manuscript's 3rd movement (agitato-rondó), mm. 1-4.

After a new presentation of the refrain (section $\mathbf{A}$ ), section $\mathbf{C}$ follows (ex. 6. mm. 58-86). The material in section $\mathbf{C}$ includes the usual superimposed 4ths interspersed with 7 th and 6 th chords. The use of fermatas written over several of these chords interrupts the natural flow of movement, providing a sense of hesitation.

According to its contents, section $\mathbf{C}$ can be divided into two distinct parts: $\mathbf{C 1}$ (ex. 6, mm. 58-67) and C2 (ex. 6, mm. 68-86).

${ }^{52}$ https://pt.wikipedia.org/wiki/Bai\%C3\%A30_(m\%C3\%BAsica)\#Caracter\%C3\%ADsticas. 
In the opening of $\mathbf{C} \mathbf{1}$, the right hand plays descending melodic fragments in quartal harmony over clusters of three notes in the left hand (ex. 6, mm. 58-63). As noted by Gonçalves (2009, p. 47), the left-hand clusters are built from a whole-tone scale (ex. 6, mm. 59-63).

The second part of $\mathbf{C} 1$ is scored using 6 th and 7 th chords, in particular, FM7 and Db6, separated by fermatas (ex. 6, mm. 64-67).

Section $\mathbf{C} 2$ opens with the same material as $\mathbf{C} 1$, the melodic fragments discussed earlier; but now, the material is presented in an inverted order. In other words, this time, the melodic motifs and their clustered chords are basically presented from the end (m. 64) to the beginning (m. 58) instead, as shown in ex. 6, mm. 58-63 (initial order) and in ex. 6, mm. 69-72 (inverted order). The left-hand clusters are basically the same, with the exception of the last one in measure 72 (ex. 6). Here, the first cluster in the inverted section, comprised of D-E-F\#, is repeated instead of the expected $\mathrm{Bb}-\mathrm{C}-\mathrm{D}$, as it was written in measure 60 (ex. 6).

The second part of $\mathbf{C} 2$ presents a new ascending material, built basically from the previous quartal motifs. It is a progression in the right hand imitated by the left hand with accelerando (ex. 6, mm. 73-78), abruptly interrupted by major 7th and 6th chords in measure 79 , where they continue to rise to the next octave register. (ex. 6, mm. 79-82). Section $\mathbf{C} 2$ concludes by repeating the FM7 chord in a higher region of the piano, with accelerando, preparing the return to the refrain (ex. 6, mm. 83-86). 


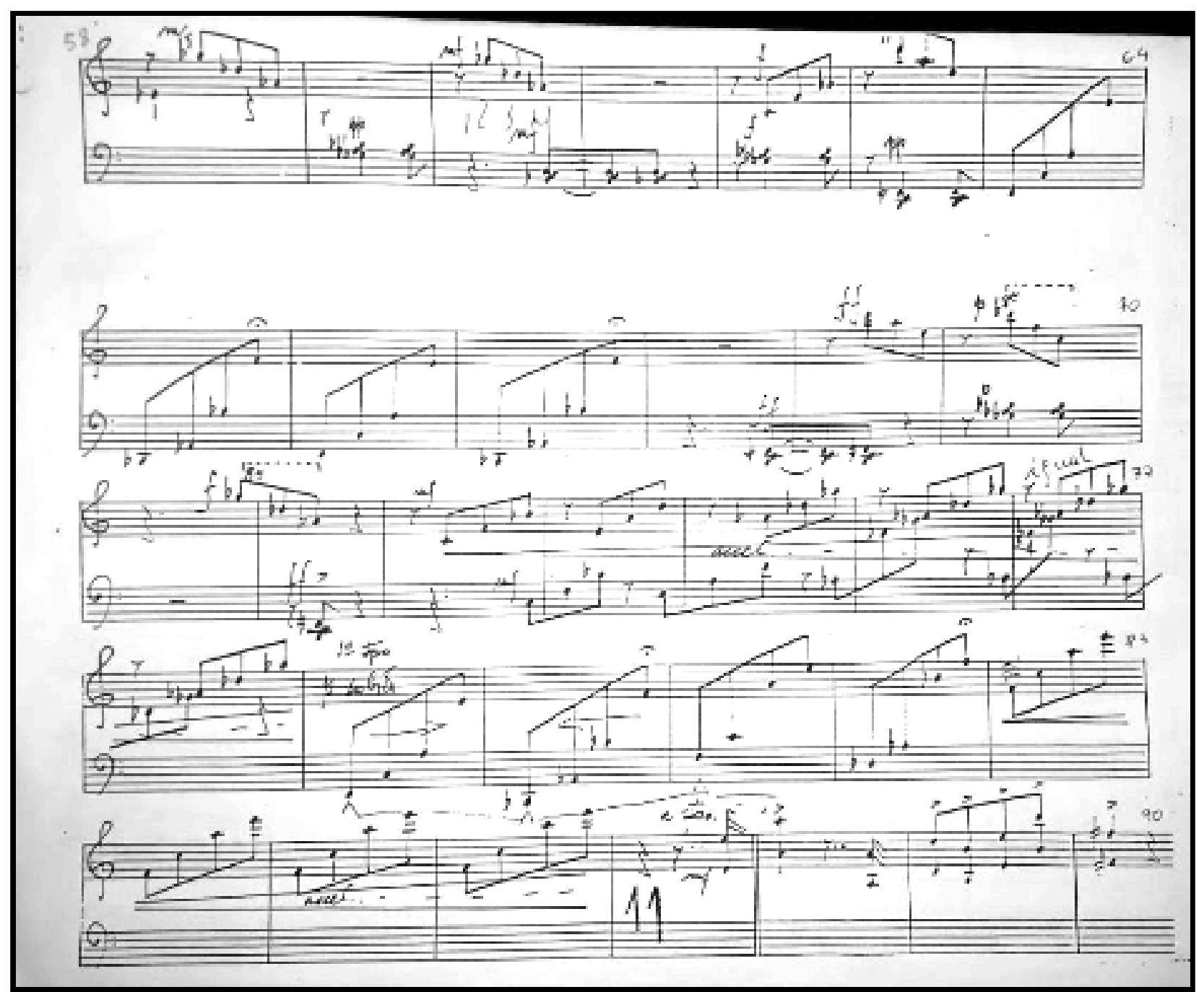

Example 6: Penalva's Piano Sonata no. 2 (1960). Manuscript's 3rd movement (rondó allegro), mm. 58-90. C section (mm. 58-86).

After the refrain, section $\mathbf{D}$ follows (mm. 97-130) . It can be divided into four main sections as follows: D1 (mm. 97-104); D2 105-107); D1' (mm. 107-117); and coda (mm. 117-130).

It opens with the composer's contrapuntal skill on full display, as he presents (ex. 7, mm. 97-101) an expressive melodic line imitated by a lower voice. Gonçalves notes the striking resemblance of this part of D1 theme with the Brazilian folk song "Casinha Pequenina" (Little House), when comparing its melody to the section of the folk tune 
that sings, "Tinha um coqueiro ao lado..." (There was a coconut tree by the side...). ${ }^{53}$ The composer's directions, such as "melodioso" (melodious), "sonoro" (sonorous), "conciso" (concise) and "amplo" (wide), suggest sections of agogic freedom, lyricism, and character contrast throughout section D (ex. 7, mm. 97-117).

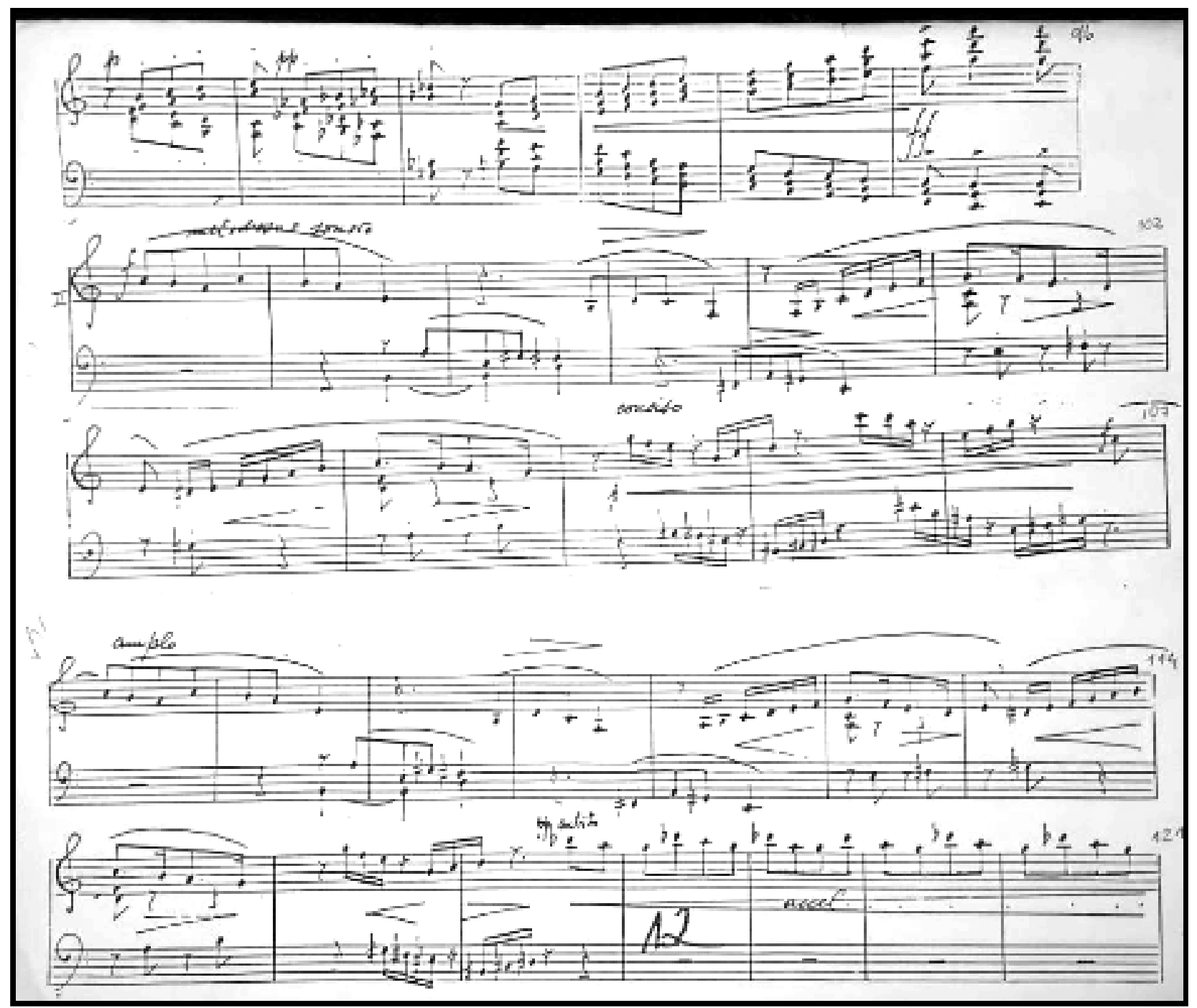

Example 7: Penalva's Piano Sonata no. 2 (1960). Manuscript's 3rd movement (rondó allegro), mm. 91-121. D section (mm. 97-117).

The melodic line of D1's second subsection (ex. 7, mm. 101-104) uses harmony and bassline textures similar to those found in section B1 (ex. 2, mm. 10-21). A more exacting section D2 is written in contrapuntal texture with bitonality, employing the

${ }^{53}$ Gonçalves, 2009, p. 49. 
direction "conciso" (concise) (ex. 7, mm. 105-107). Following that, D1 appears once again (D1'), but its second section D2 (ex. 7, mm. 116-117), is abruptly interrupted by a transitional section set up by melodic motifs of eighth notes in a higher region of the piano. Thus begins a transition toward the final statement of section $\mathbf{A}$. This transition is composed from the recurrent motif of three main notes (Bb4-A4-G4), occasionally interspersed with perfect-4th and augmented-4th intervals in the lower register of the piano, and the addition of superimposed 4 th chords at the very end (ex. $8, \mathrm{~mm}$. 122-124; 129-130).

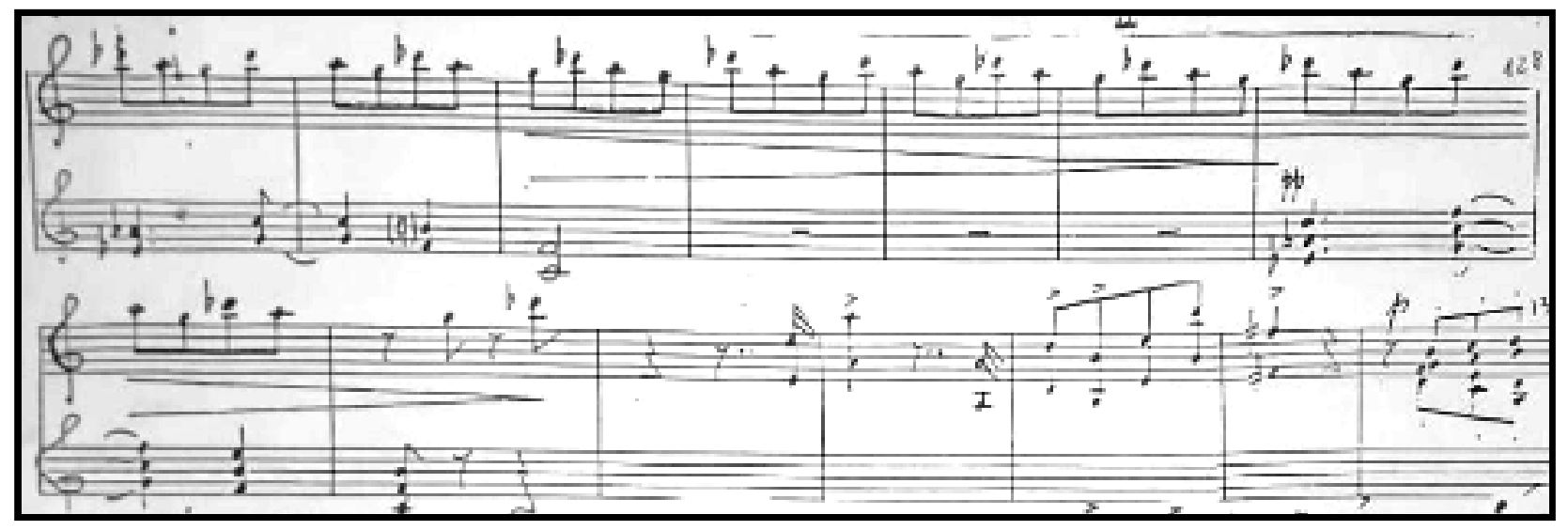

Example 8: Penalva's Piano Sonata no. 2 (1960). Manuscript's 3rd movement (rondó allegro), mm. 122-135.

Following the transition, the final refrain (mm. 1-10) appears, culminating in a unison of two A pitches in fortississimo, in the extreme high and low regions of the piano (ex. 9).

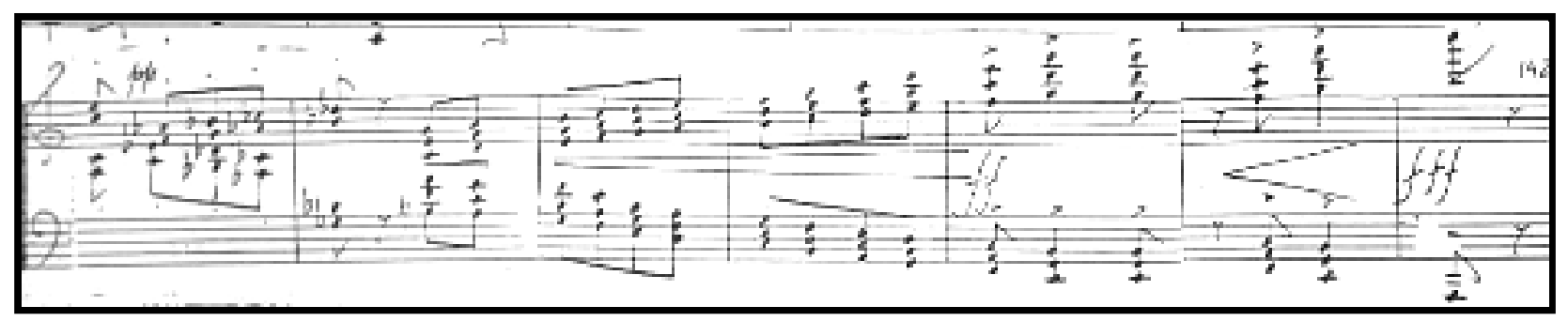

Example 9: Penalva's Piano Sonata no. 2 (1960). Manuscript's 3rd movement (rondó allegro), final refrain $(\mathrm{mm} .136-142)$. 
The Sonata no. 2 combines classical forms and modal language with incidental atonality and unusual cadential formulas within the modalism. Drawing upon his familiarity with vocal repertoire, this sonata also demonstrates Penalva's great contrapuntal skills, along with smoothly idiomatic writing for the piano. Although there are no literal quotations of other composers' material, he intentionally employs stylistic elements from composers like Bartok (neo-classical forms, quartal harmonies, folk styles), Gershwin (jazz flavors), Guarnieri (irregular meters, lyrical melodic lines, abrupt harmonic changes), and Webern (symmetrical structures).

Despite working with such diverse compositional features and styles, Penalva is able to organize this sonata in the service of a greater goal, connecting the thematic ideas throughout the entire sonata. 


\subsection{Sonata no. 3}

\section{Allegro}

Exposition: (mm. 1-30)

A (1-5) T1 (6-7) B (8-14)

T2 (15-17) C [C1(18-21) - C2(22-25)] T3 (26-30)

Development: (mm. 31-61)

D1 (31-38) DT (39-40) D2 (41-50) D1' (51-61)

Recapitulation: (mm. 62-91)

A' $(62-65)$

T1 (66-67)

B (68-74)

T2 (75-77)

C [C1(78-81) - C2(82-85)]

Coda (86-91)

According to the composer, the everyday violence of that time period had an impact on his composition of Sonata no. 3, which dates from 1991. In his own words “...a violência da música de hoje se explica porque os tempos são assim.” (“...today's violence is explained because the times are what they are.") (Penalva as cited in Fregoneze, 1992, p. 68). Among the three sonatas, this is the most demanding, requiring great technical skill from the pianist. Penalva reused the material of movements two and three (Andante and Agitato rondó) in his later piece "Três 
momentos" (Three Moments) for strings (1990-1993), under the titles Lied and Rondó-Agitato, respectively.

As we observed in Sonatas no. 1 and no. 2, Sonata no. 3 also reveals classical forms. Its first movement Allegro is in sonata-allegro form and, asin the Sonata no. 2, Penalva uses thematic groups in which the first theme displays an introductory character. Themes A and B contrast significantly.

Theme $\mathbf{A}$ has an energetic, rhythmic character and its texture is homophonic (ex. 1, mm. 1-5). The composer left a written footnote on the score regarding the triplet rhythms: "Por sua frequência e clara posição no ritmo, não apontaremos a presença da quiáltera" (For their frequency and clear position into the rhythm, we will not point out the triplet's presence" (ex. 1a). It is mainly constructed from augmented 4ths and diminished 5ths where dynamic accents emphasize different points of the meter. This procedure enriches the musical idea, enhancing other intervals that occur, and providing interest to the obvious parallelism of the tritones (ex. 1, m. 5).

Theme $\mathbf{A}$ has an introductory character, where two gestures ascending $(\mathrm{mm}$. 1-3) and descending (mm. 4-5) in powerful octaves and unisons generate a great expectation. Despite the prominence of tritones, other intervals are present, like 2nds, 3rds, 6ths and 7ths. As a matter of fact, this initial material (mm. 1-5) contains all the intervallic motifs which will be employed during the upcoming main sections.

Its monophonic texture is directly related to the first-movement themes of Penalva's other sonatas. Sonata no. 1 begins with an introductory and polyphonic theme which is further developed three times before the B theme appears (ex. 2). Sonata no. 2 opens with an introductory melodic line in octaves, interspersed with 
chords in the extreme registers of the piano, material that will be broadly explored throughout the entire first movement (ex. 3). Given the large space of time between the composition of these sonatas, 1960 (no. 2), 1970 (no. 1) and 1991 (no. 3), it makes sense to conclude that this style of thematic writing is a trait of the composer.

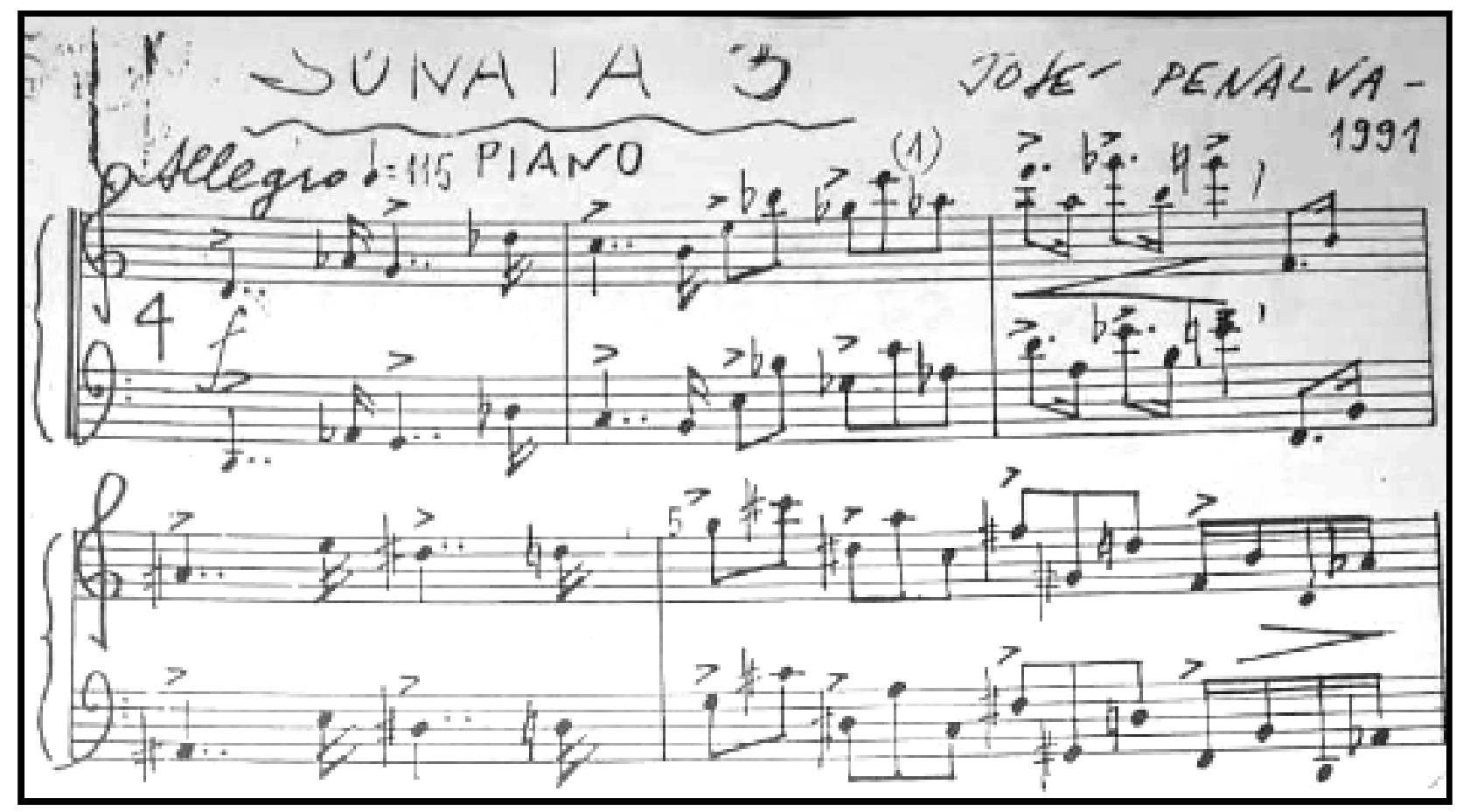

Example 1: Penalva's Piano Sonata no. 3 (1991). Manuscript's 1st movement (allegro), mm. 1-5.

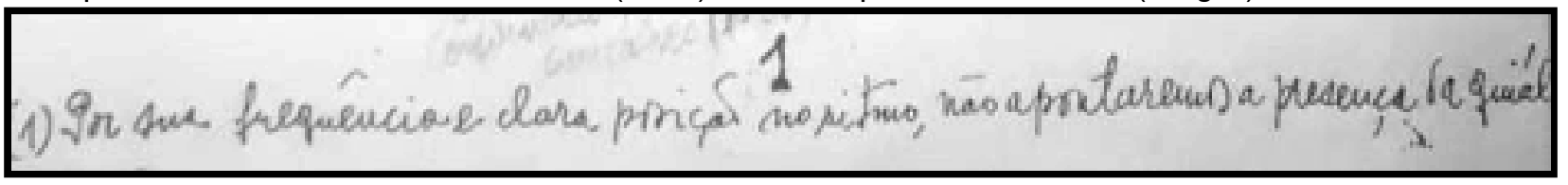

Example 1a: Penalva's Piano Sonata no. 3 (1991). Manuscript's 1st movement (allegro), p. 1, footnote.

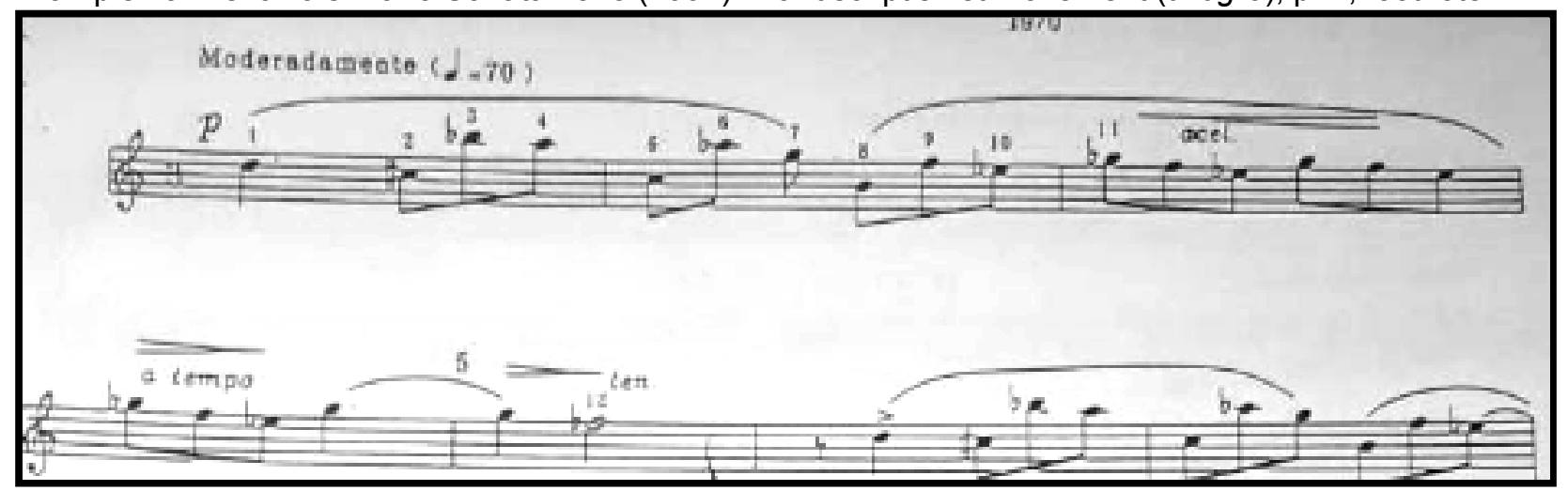

Example 2: Penalva's Piano Sonata no. 1 (1970), Ricordi's edition (1972), mm. 1-7. A theme (mm. 1-5). 


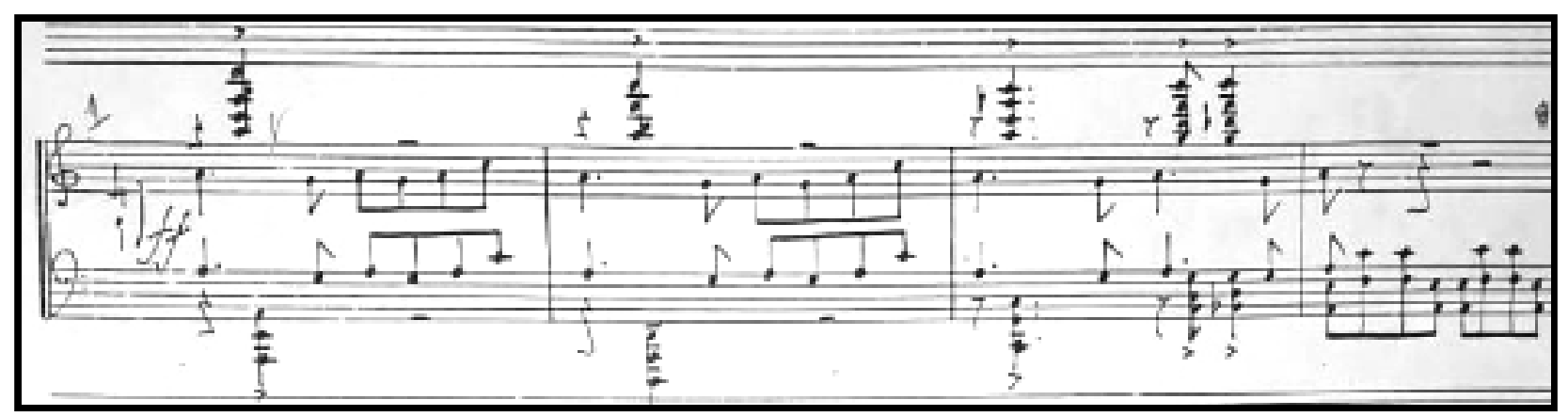

Example 3: Penalva's Piano Sonata no. 2 (1960). Manuscript's 1st movement (moderato), mm. 1-4. A theme.

Following Theme A, Penalva composes a transition, T1, using mirrored writing (ex. 4), derived from the minor 2 nds of theme A (ex. 1, mm. 1;4). Penalva seems to have used a compositional technique similar to one he employed with an accompaniment figure in Sonata no. 1 (ex. 5, mm. 19-22).

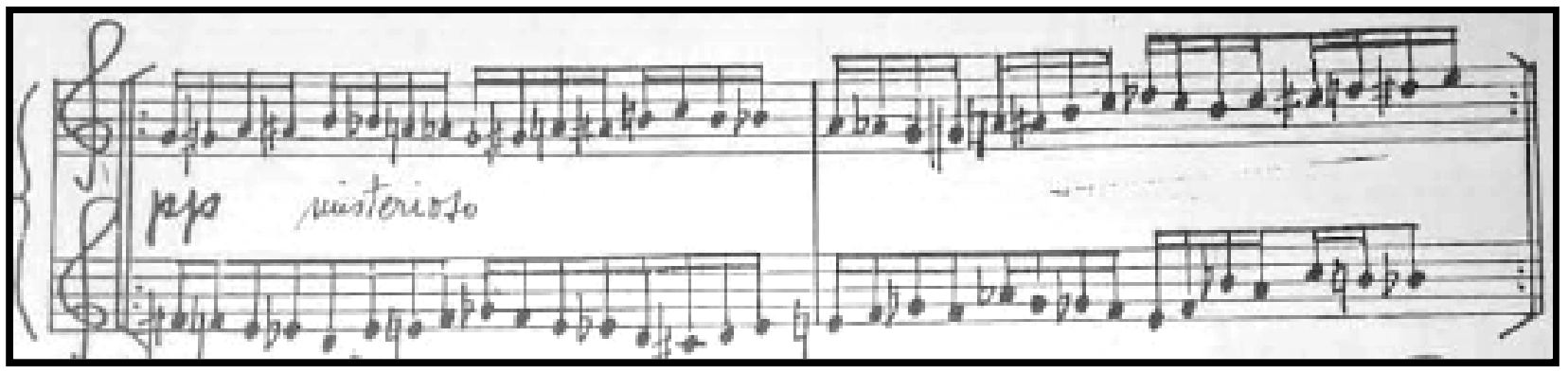

Example 4: Penalva's Piano Sonata no. 3 (1991). Manuscript's 1st movement (allegro), mm. 6-7. Transition to $\mathbf{B} 1$ theme.

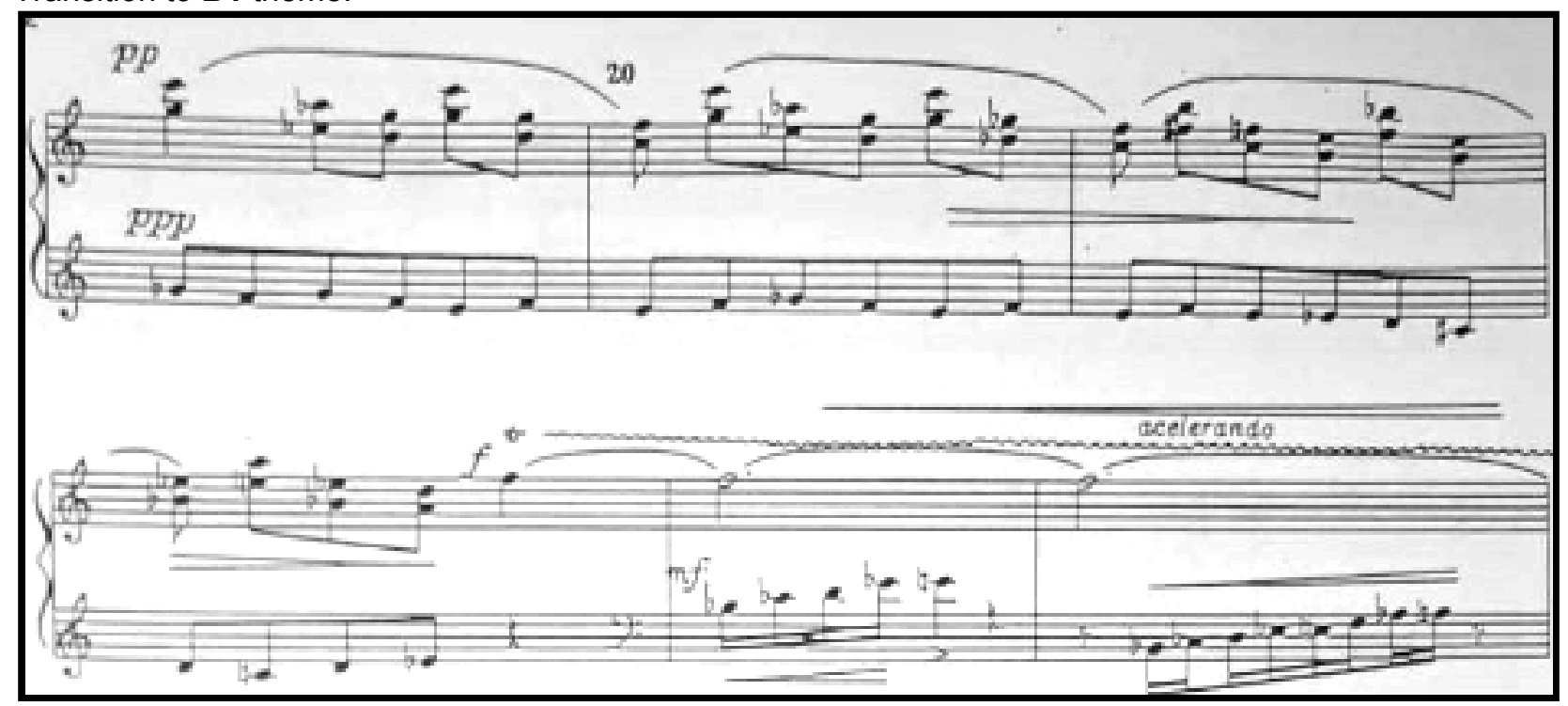

Example 5: Penalva's Piano Sonata no. 1 (1970). Ricordi's edition (1972), mm. 19-24. 
After the transition, T1, theme B follows (ex. 6, mm. 8-14), displaying a homophonic texture with the character direction cantabile. It contrasts significantly with theme A's energetic and monophonic texture. Nevertheless, theme $\mathbf{B}$ is largely elaborated with compositional materials from theme $\mathbf{A}$, such as augmented 4 ths (and diminished 5ths), minor 2nds in the accompaniment, and major and minor 6ths from the melodic line. Additionally, both the melodic line and the accompaniment emulate the contour of the initial motif of theme A. Penalva's directions indicate some agogic freedom in theme B as well. He marks crescendo, accelerando (ex. 6, mm. 12-13), acalmando-se (calming down), and meno (ex. 6, mm. 14-15). These indications demonstrate further contrast with theme $\mathbf{A}$.

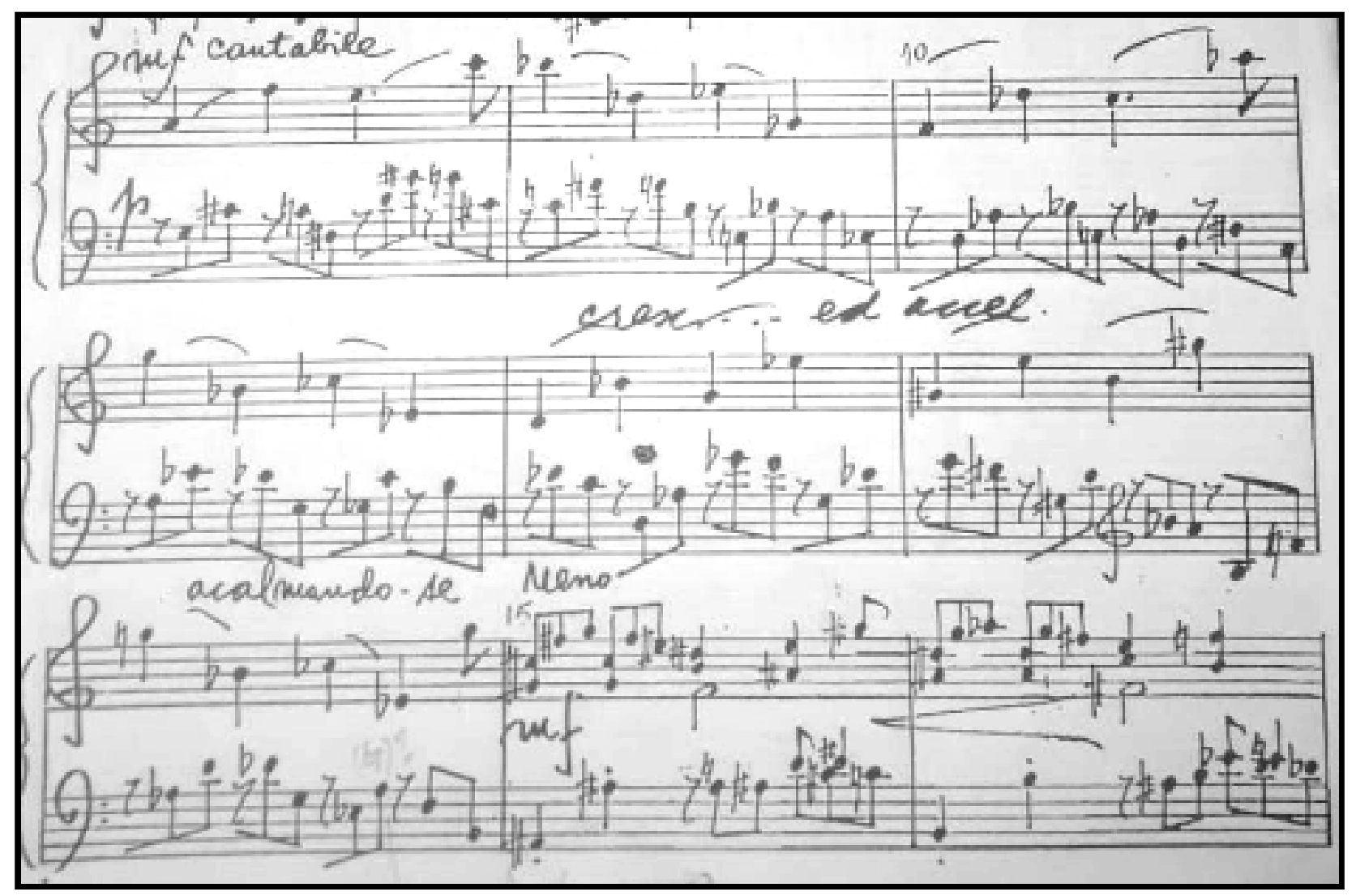

Example 6: Penalva's Piano Sonata no. 3 (1991). Manuscript's 1st movement (allegro), mm. 8-16. B theme (mm. 8-14). 
Following theme $\mathbf{B}$, there is a second transition, $\mathbf{T} 2$, that includes materials from theme $\mathbf{A}$, and from the previous transition, such as augmented 4ths, chromaticism, and mirrored writing (ex. 7, mm. 15-17). T2 is comprised of symmetrical chromatic progressions which build rhythmically and chromatically toward the last measure, where both elements begin to be modified (ex. $7, \mathrm{~m} .17)$, increasing the tension and preparing the presentation of theme $\mathbf{C}$. There have been many examples of Penalva's use of augmented 4ths, diminished 5ths, and quartal harmony as typical of his compositional style; these are also present in transition T2 (ex. 7, mm. 15).
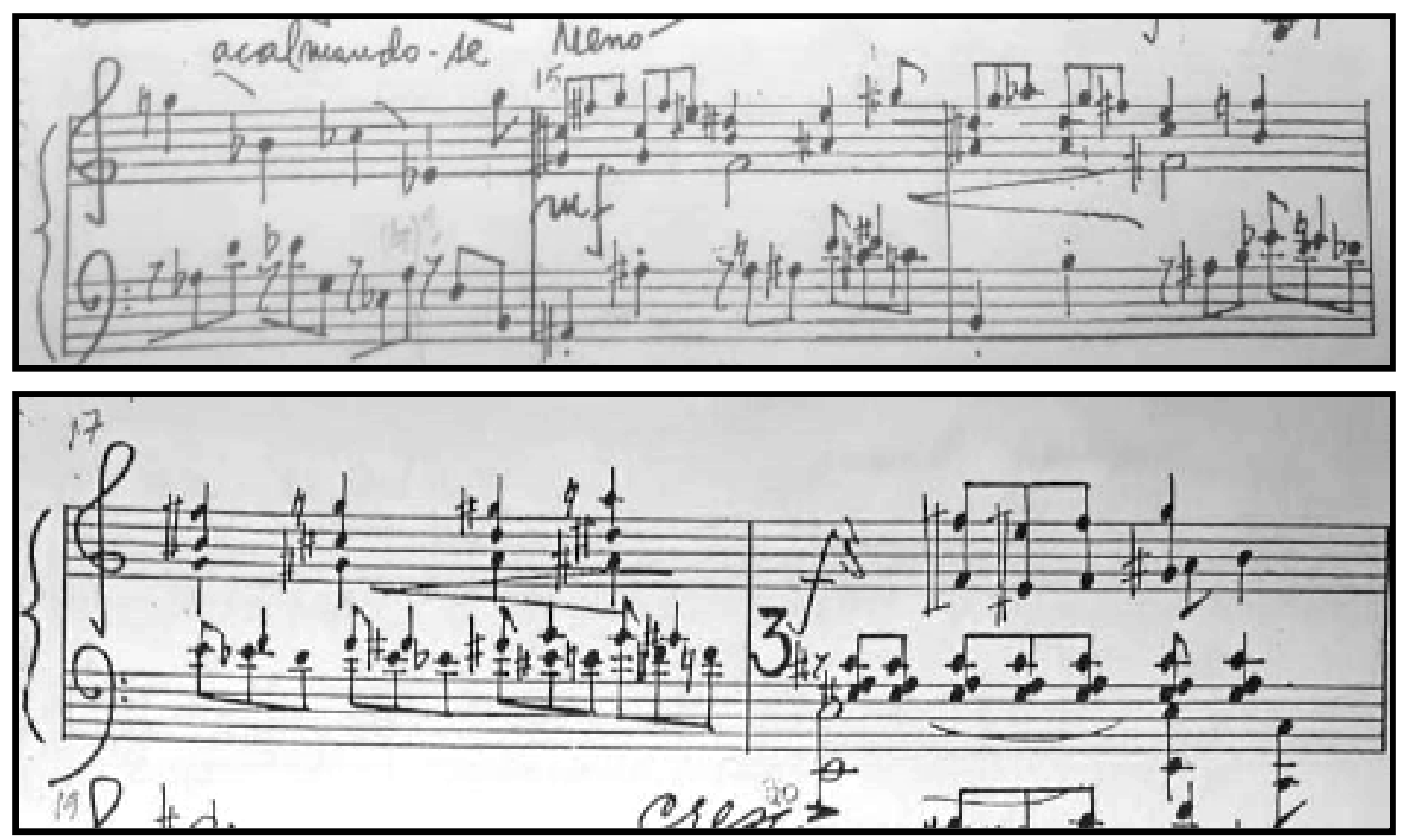

Example 7: Penalva's Piano Sonata no. 3 (1991). Manuscript's 1st movement (allegro), mm. 14-18. Transition to $\mathbf{C}$ (mm. 15-17).

Theme $\mathbf{C}$ starts in measure 18 (ex. 8). Because triplet figures were employed in the transition (ex. 7, mm. 15-17) and further, from the beginning of theme $\mathbf{B}$ (ex. 6, mm. 
8-14), the change to a ternary time signature for theme C (ex. 8, m. 18) feels organic and smooth.

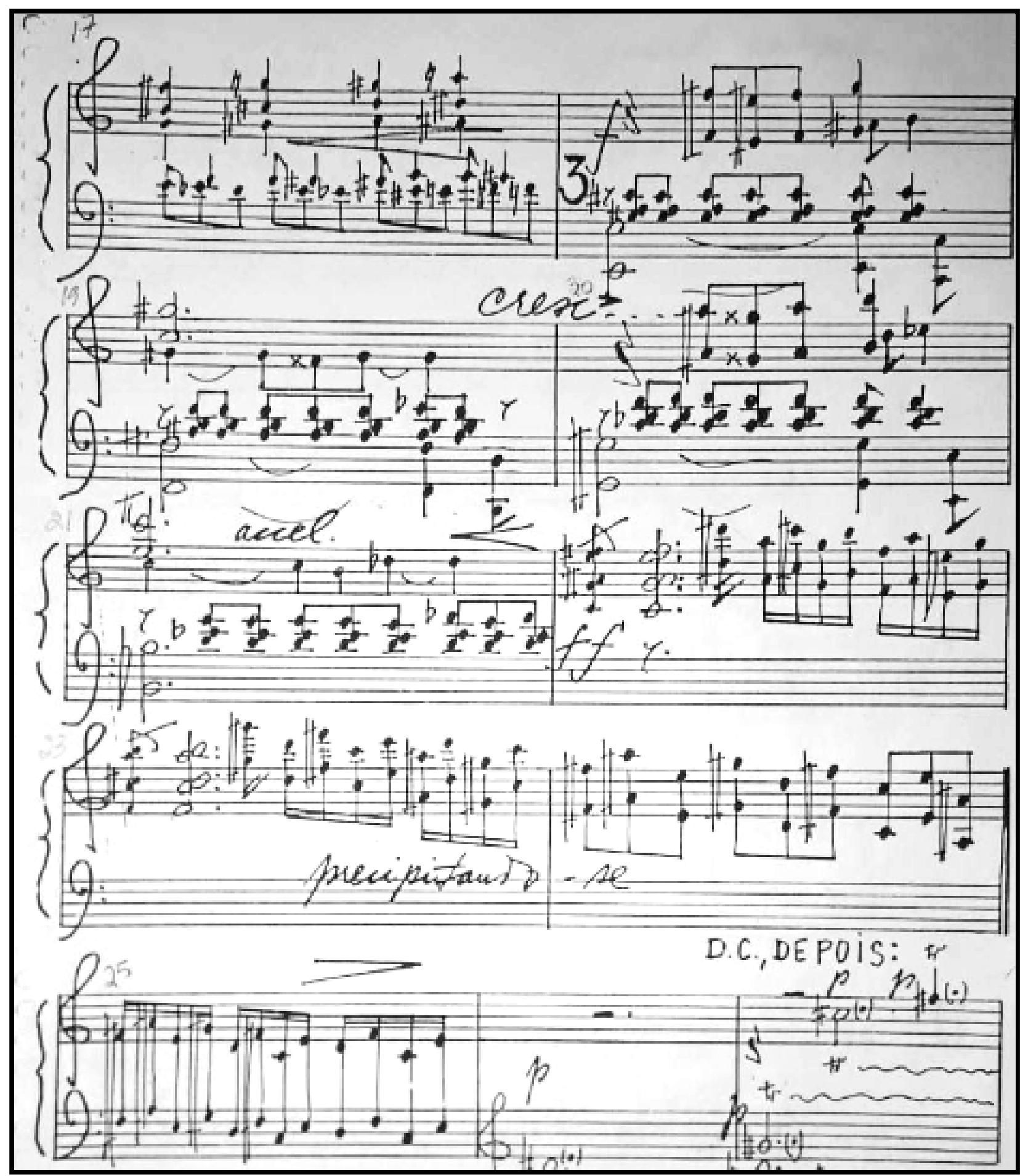

Example 8: Penalva's Piano Sonata no. 3 (1991). Manuscript's 1st movement (allegro), mm. 17-26. C theme (mm. 15-25). 
Due to its differing textures and characters, theme $\mathbf{C}$ can be divided into two distinct parts: C1 (ex. 8, mm. 18-21) has a melodic character and homophonic texture. C2 (ex. 8, mm. 22-25) has a rhythmic character and monophonic texture.

In part $\mathbf{C 1}$, the melodic contour and inner voicing in both hands are inherited from the chromaticism of T1 and are now rhythmically expanded (ex. 4). C1 also employs augmented 4ths from theme $\mathbf{A}$ in its bass line.

Part $\mathbf{C 2}$ has the same energetic, rhythmic character of the initial theme A. As Gonçalves observes, it opens with a chordal appoggiatura using the same intervals found in the initial expositional theme: major 2nds and their inversions, augmented 4ths, and major and minor 6 ths and their inversions (2009, p. 94). These chords are followed by a descending sequence of augmented 4ths, marked precipitando-se (acting in haste), which leads to a final transition T3. Here, Penalva's standard quartal texture with an overlay of minor 2 nd trills, reminds us of the initial theme A motif (ex. 9, mm. 26-30). 


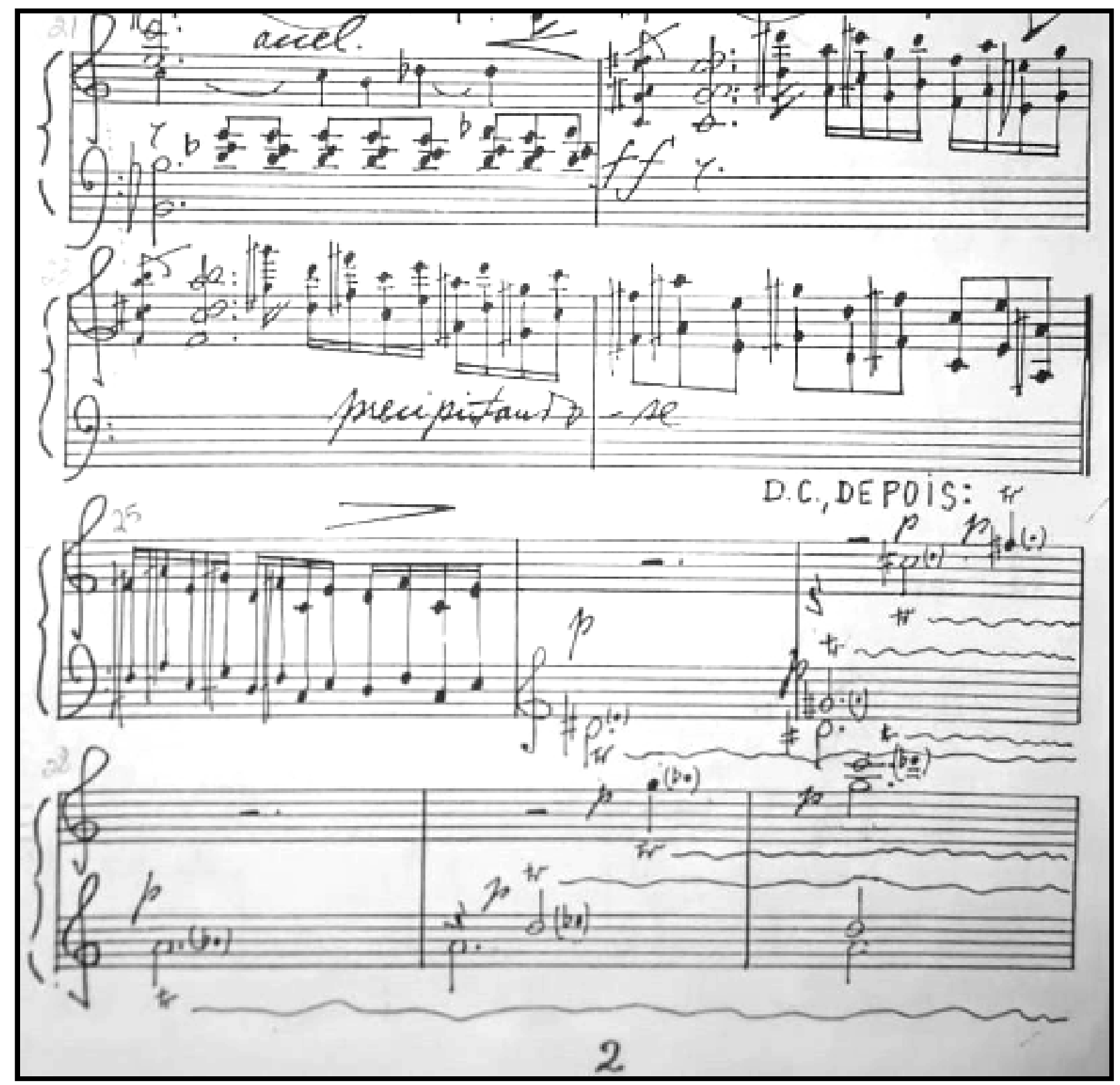

Example 9: Penalva's Piano Sonata no. 3 (1991). Manuscript's 1st movement (allegro), mm. 21-30. C2 theme $(\mathrm{mm} .22-30)$. Its second part ( $\mathrm{mm} .26-30)$ works as a transition to the development.

The development section, $\mathbf{D}$, begins in measure 31 . As is traditional, many of the materials employed in the exposition reappear. For instance, Penalva uses chromaticism, perfect and augmented 4ths, major and minor 6ths, major and minor 3rds, and major and minor 2nds (ex. 10). 
The development can be divided into three distinct parts, according to its different textures, as follows: section D1 (ex. 10, mm. 31-38); section D2 (ex. 11-12, mm. 41-50); and section D1' (mm. 51-61).

Section D1 (ex. 10, mm. 31-38) primarily employs chromaticism that alternates between ascending and descending material. Initially, there is an ascending chromatic passage in both hands. The right hand plays a single melodic line while the left hand performs a chromatic line of perfect 4ths. At first, the texture is thin (mm. 31-32); but later it is broadened by the addition of octaves in the left hand, and 4ths and octaves in the right hand (mm. 32-34). The intervals employed are all taken from the exposition: minor 2nds, perfect octaves and perfect 4ths (mm. 31-34). In measure 34 (beat 2) and measure 35, B theme's material is inverted, as shown in ex. $14(\mathrm{~m} .8)$. The melodic minor 6ths from $\mathbf{B}$ theme are now presented in the bass line and the original accompaniment's augmented 4ths now appear as a melodic figuration in the right hand, noticeably without their original directional changes (ex. 10, mm. 34-36). ${ }^{54}$ Despite the ternary meter, the position of the bassline's melodic 6ths suggests a binary pulse (ex. 10 , mm. 34, beat 2 - 36, beat 1). In fact, along with the written chromaticism, this internal rhythmic feature helps to smooth the transition back to a quaternary meter (ex. 10, mm. 34-36).

The initial ascending chromatic melody is essential to the development section, utilizing pitches $\mathrm{F} \# 3$ to $\mathrm{Cb} 4$, as seen in ex. $10, \mathrm{~mm} .31-32 .{ }^{55}$ The continued use of augmented 4ths creates a descending version of the initial development's ascending

\footnotetext{
${ }^{54}$ Compare with ex. $14, \mathrm{~m} .8$.

${ }^{55}$ Obviously, the following measures 33-34 (1st beat) can be also used for the same comparison.
} 
gesture (T1's material), using different pitches, in both upper and lower voices (B theme's material) (ex. 10, mm. 34, 2nd beat - 36, 1st beat). ${ }^{56}$

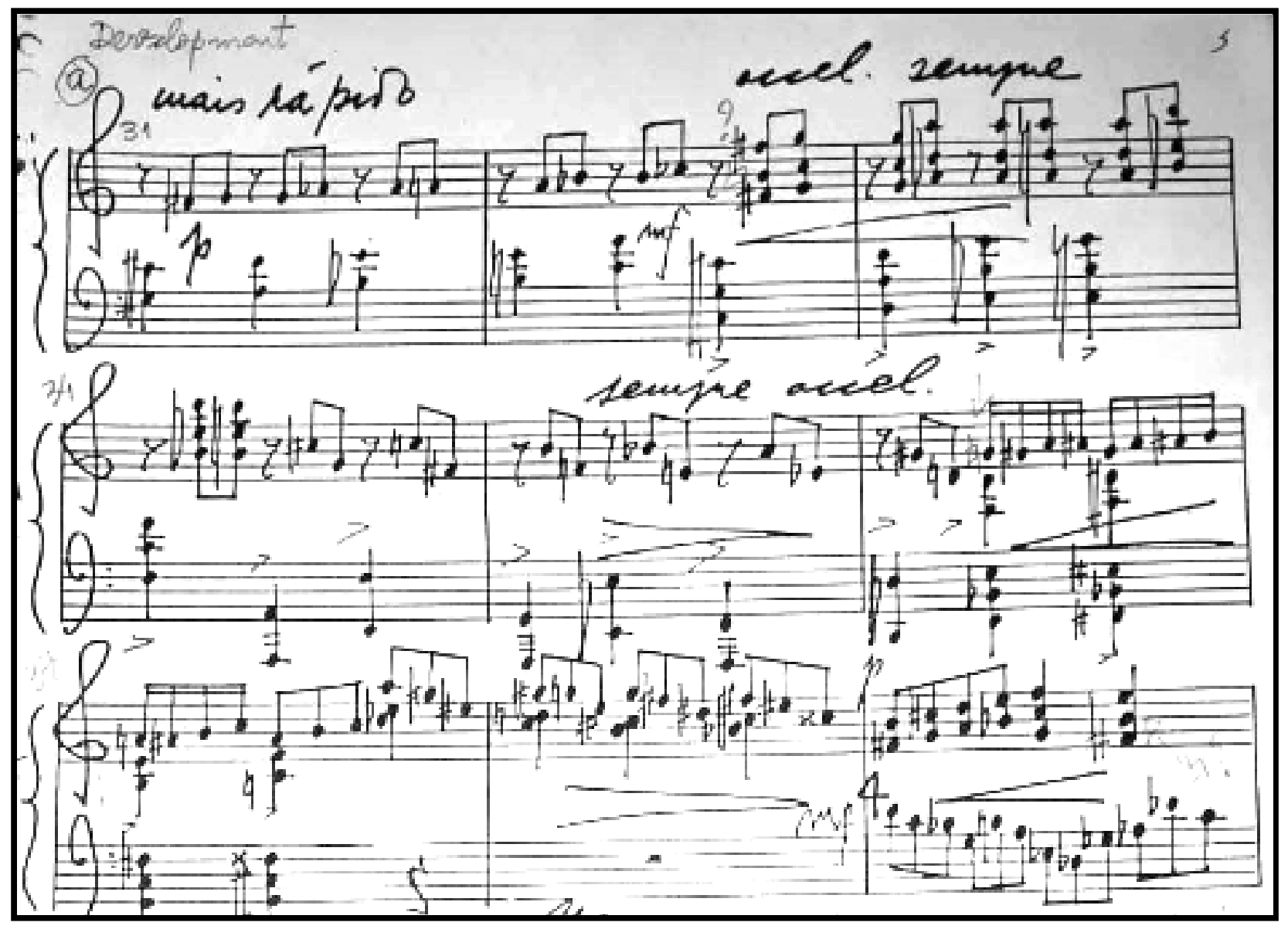

Example 10: Penalva's Piano Sonata no. 3 (1991). Manuscript's 1st movement (allegro), mm. 31-39.

From measure 36 beat 2 to measure 37 beat one, this chromatic material becomes more dense, both rhythmically and melodically, by the employment of sixteenth notes instead of the previous triplets, and by ascending groups of four chromatic pitches instead of two (ex. 10). The previous octave bass lines give way to quartal chords in different combinations, where chromatic movement in the chords' external voices takes place again in the left hand (ex. 10). ${ }^{57}$

\footnotetext{
${ }^{56}$ Compare with the right hand's passage in mm. 31-32, 2nd beat (ex. 10).

${ }^{57}$ Assuming the possible mistake in the second chord of the left hand "F\#-B(?)-E\#" (ex. 10, m. 36), the chromatic movement would actually be in all three voices.
} 


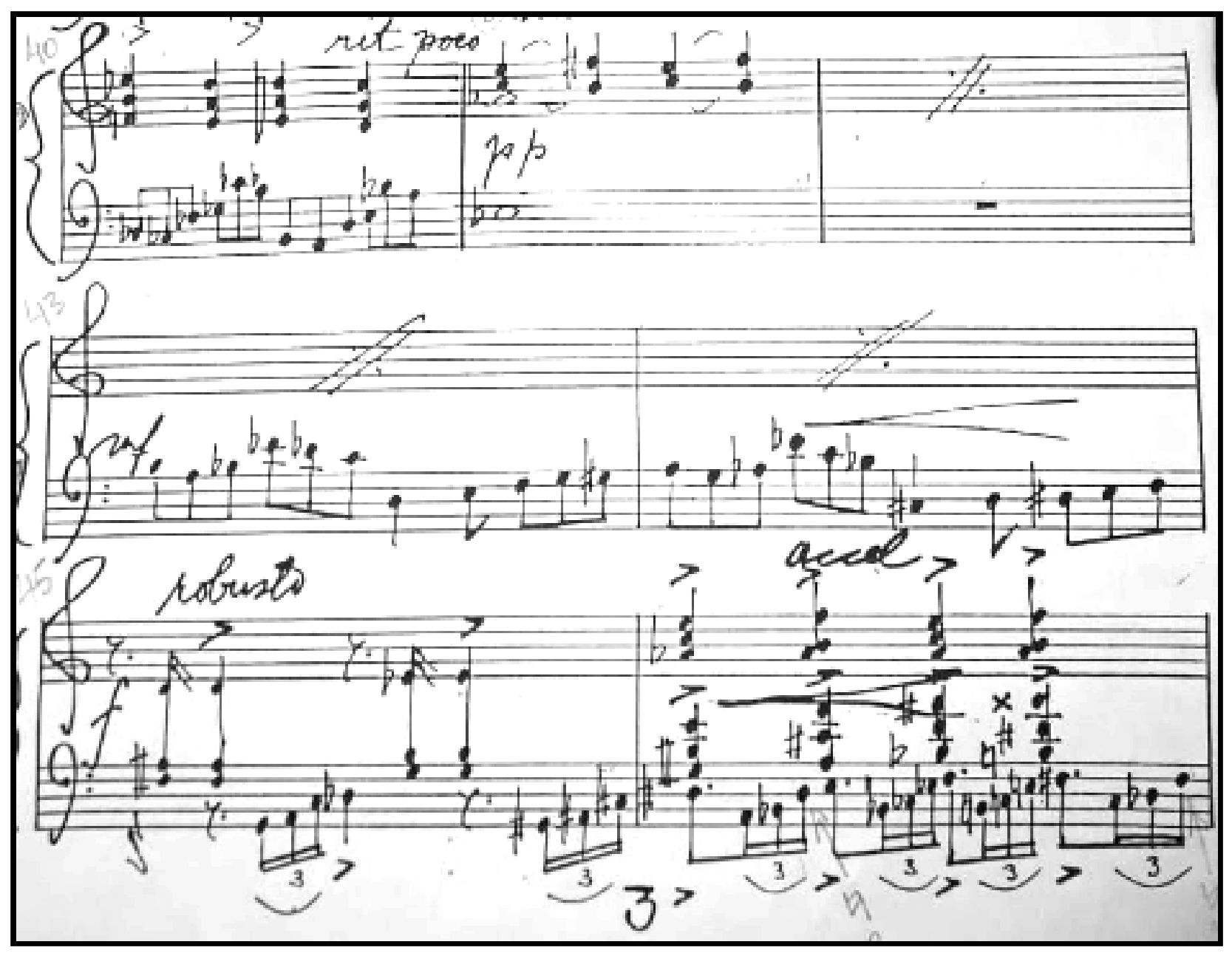

Example 11: Penalva's Piano Sonata no. 3 (1991). Manuscript's 1st movement (allegro), mm. 40-46.

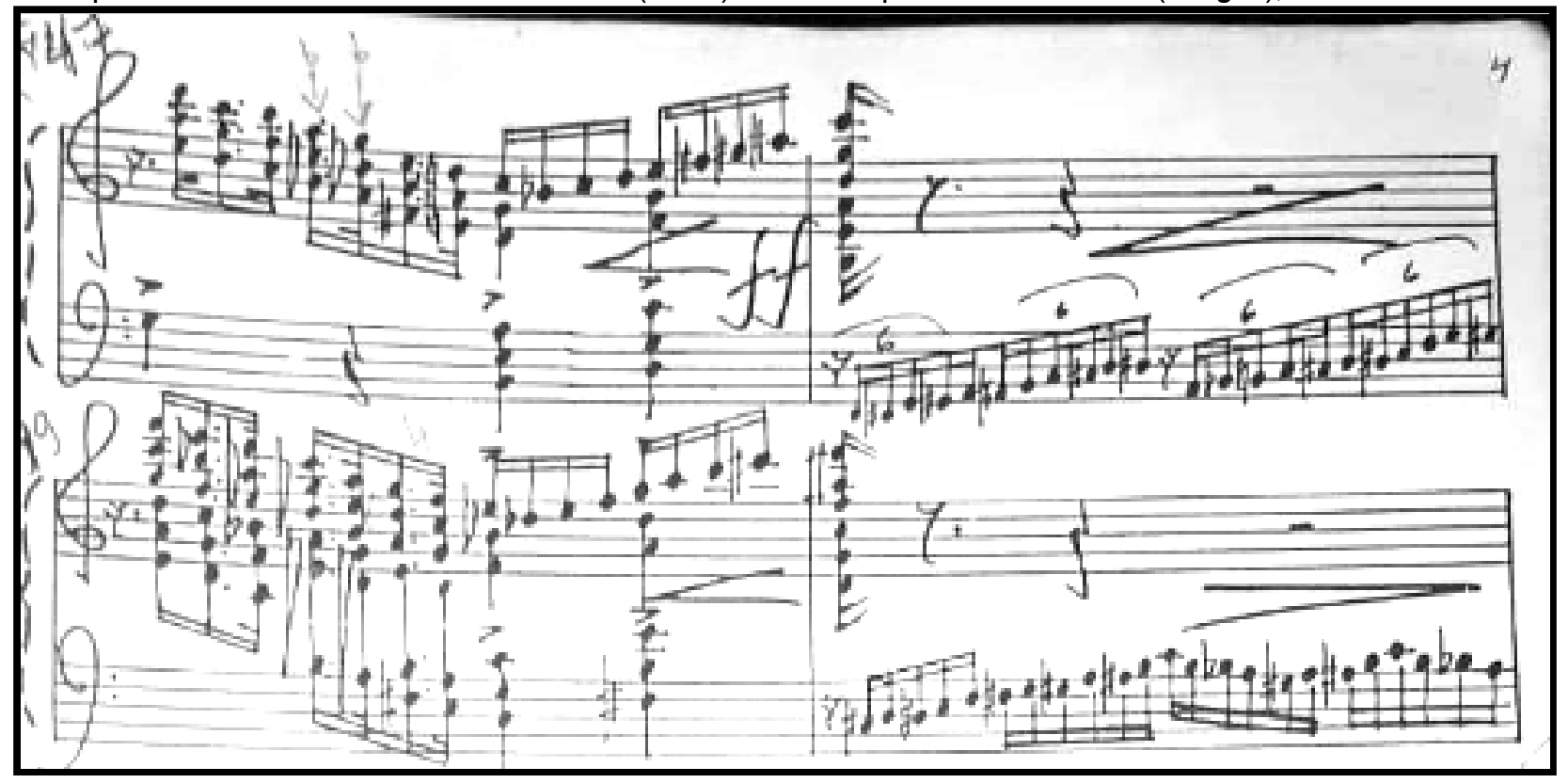

Example 12: Penalva's Piano Sonata no. 3 (1991). Manuscript's 1st movement (allegro), mm. 47-50. 


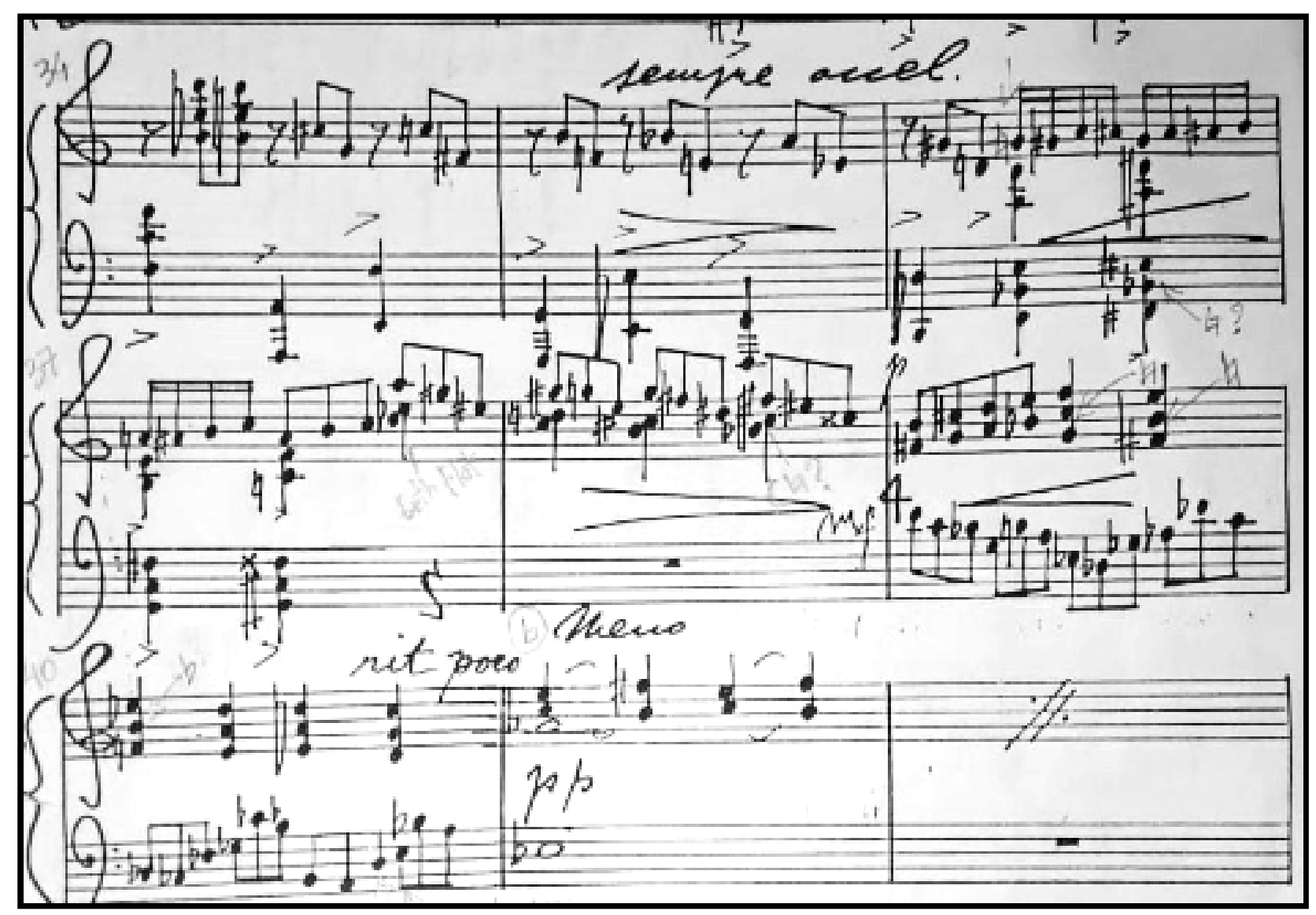

Example 13: Penalva's Piano Sonata no. 3 (1991). Manuscript's 1st movement (allegro), mm. 34-42.

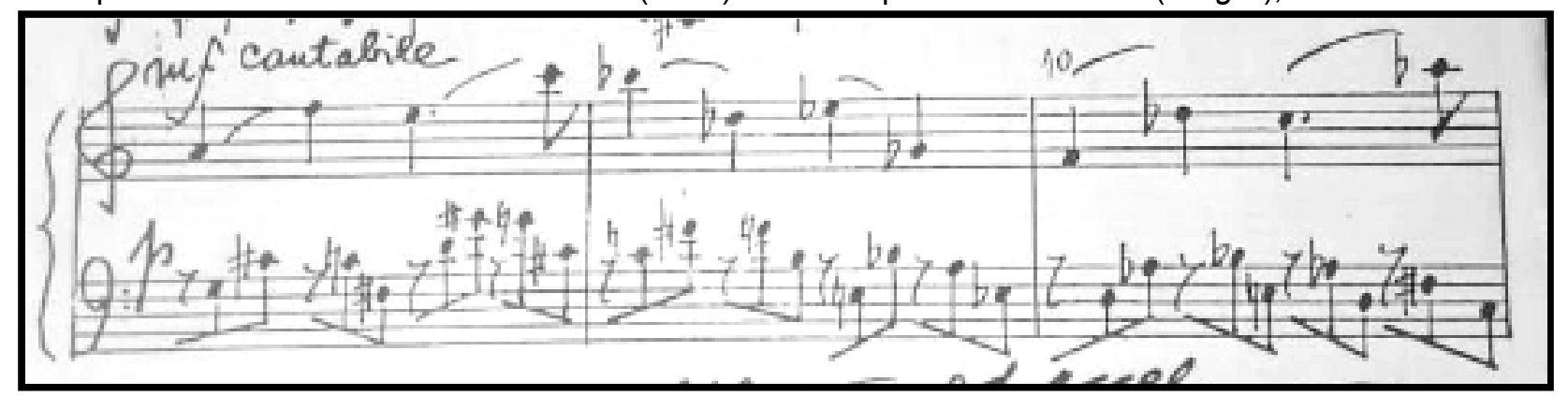

Example 14: Penalva's Piano Sonata no. 3 (1991). Manuscript's 1st movement (allegro), mm. 8-10.

The texture is also enriched by the addition of superimposed "perfect chords" (chords made up of only perfect intervals) in the right hand (ex. $10, \mathrm{~mm} .36,2$ nd beat -37 , 2nd beat). Development section D1 ends with material in only the upper staff. Minor 2nd and 3rd melodic figurations in triplets join with major 2 nds in quarter notes to form a descending chromatic passage. The stepwise melodic motion of minor 2 nds in the 
upper voice (ex. 10, mm. 37, 3rd beat - 38) creates a descending version of the initial chromatic ascent. (ex. 10, mm. 31-32).

A short, polyphonic transition (DT1) follows (ex. 13, mm. 39-40). ${ }^{58}$ Its material is composed of augmented 4 ths and perfect 4 ths, as well as quartal chords in the right hand. The previous triplet material that occurred just prior is now written for the left hand. The triplets are built from perfect and augmented 4ths and 5ths, minor $3 \mathrm{rds}$, and major 2 nds. The upper melodic contour is both diatonic and chromatic. The chromatic part of it (ex. 13, m. 39, 3rd beat - m. 40) resembles previous scoring, like the melodic augmented 4ths that descend chromatically in the development's A section (ex. 13, mm. 34-37).

Section D2 (mm. 41-51) is elaborated with materials from the exposition and from the development so far. It begins with an ostinato on an augmented triad (Ab3-C4-E4) and a minor 7th chord (Ab3-B3-F\#4), ${ }^{59}$ supported by an Eb2 pedal in the bass line of its first measure (ex. 15a, m. 41).${ }^{60}$ Next, the ostinato continues in the right hand with a melodic bassline varied from the triplet figure of the development's transition (ex. 15a, $\mathrm{mm} .43-44)$. This bassline variation is taken from the melodic contour of triplets in the left hand (ex. 15b, m. 39, beats 3 and 2, respectively), and also from the first diatonic motif in the right hand (ex. 15b, m. 39, top notes: C\#-D-E-F). ${ }^{61}$

The next two measures (mm. 45-46) employ many materials from this previous section: augmented 5th and 7th chords, triplets, and especially, the allegro's opening

\footnotetext{
${ }^{58}$ As the first development transition DT1 ( $\mathbf{m m} . \mathbf{3 9 - 4 0 )}$ is literally repeated in D1' (mm. 59-60), I thought it was appropriate to label it DT1 without mentioning the implicit DT2.

${ }^{59}$ Considering the enharmonic possibility "Ab3-Cb4-Gb4."

${ }^{60}$ Although not exactly the interval found in the parallel place in the exposition, the augmented 5th can be considered enharmonically a minor 6th, thus largely employed in the primary zone's B theme (ex. 14).

${ }^{61}$ The lower notes of the melodic 4th intervals (since it is from the first beat of $\mathrm{m}$. 39) also set up the same diatonic interval that appears in the top voices (F\#-G-A-Bb).
} 
rhythmic motif of a dotted eighth and a sixteenth note (ex. 15a, mm. 45-46). In the next four measures (mm. 47-50), the initial rhythmic motif is enhanced by quartal chords over whole-tone scales, and ascending chromatic scales, ${ }^{62}$ all inherited from the transition of the exposition (ex. 16, mm. 47-50).

Following this, D1' is presented (ex. 17, mm. 51-61). An alteration occurs at the very beginning in measure 60 beat 2 , in that the left-hand melodic line is now ascending instead of descending. Its first triplets ${ }^{63}$ are built on a whole-tone scale (ex. 17, mm. 60-61). In this same place, there are augmented and perfect 4 th chords for the right hand which also comprise a whole-tone scale (ex. 17, mm. 60-61).

\footnotetext{
62 There is a scoring mistake on the last note of the chromatic scale in measure 50 (ex. 17). Because of the previous $\mathrm{Bb} 2$, it is obviously an $\mathrm{A} 2$ natural.

${ }^{63}$ Except for the last triplet (ex. 17, m. 61), which should have its second note (F\#3) considered as part of the whole tone scale, for the obvious reason of the change in direction.
} 


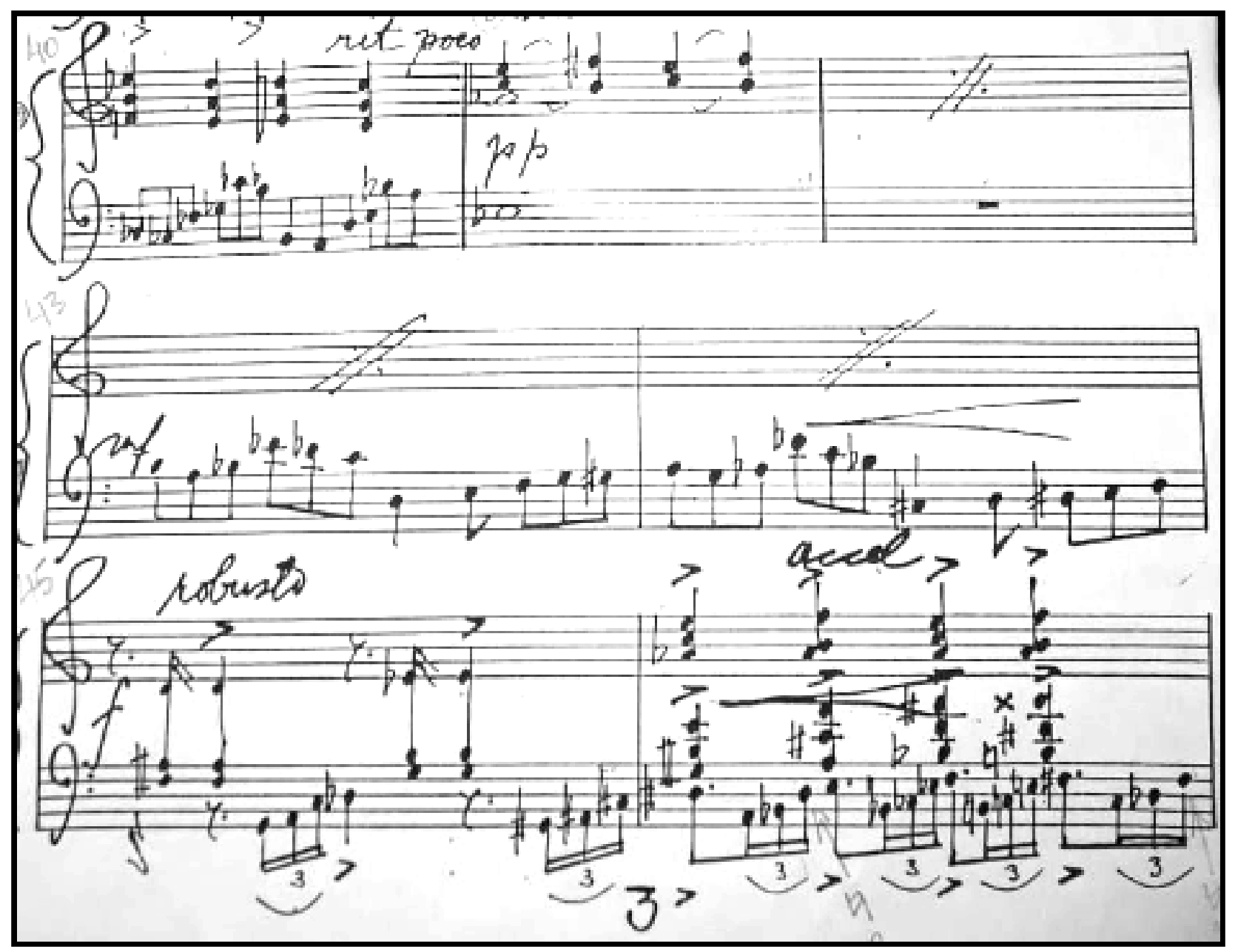

Example 15a: Penalva's Piano Sonata no. 3 (1991). Manuscript's 1st movement (allegro), mm. 40-46.

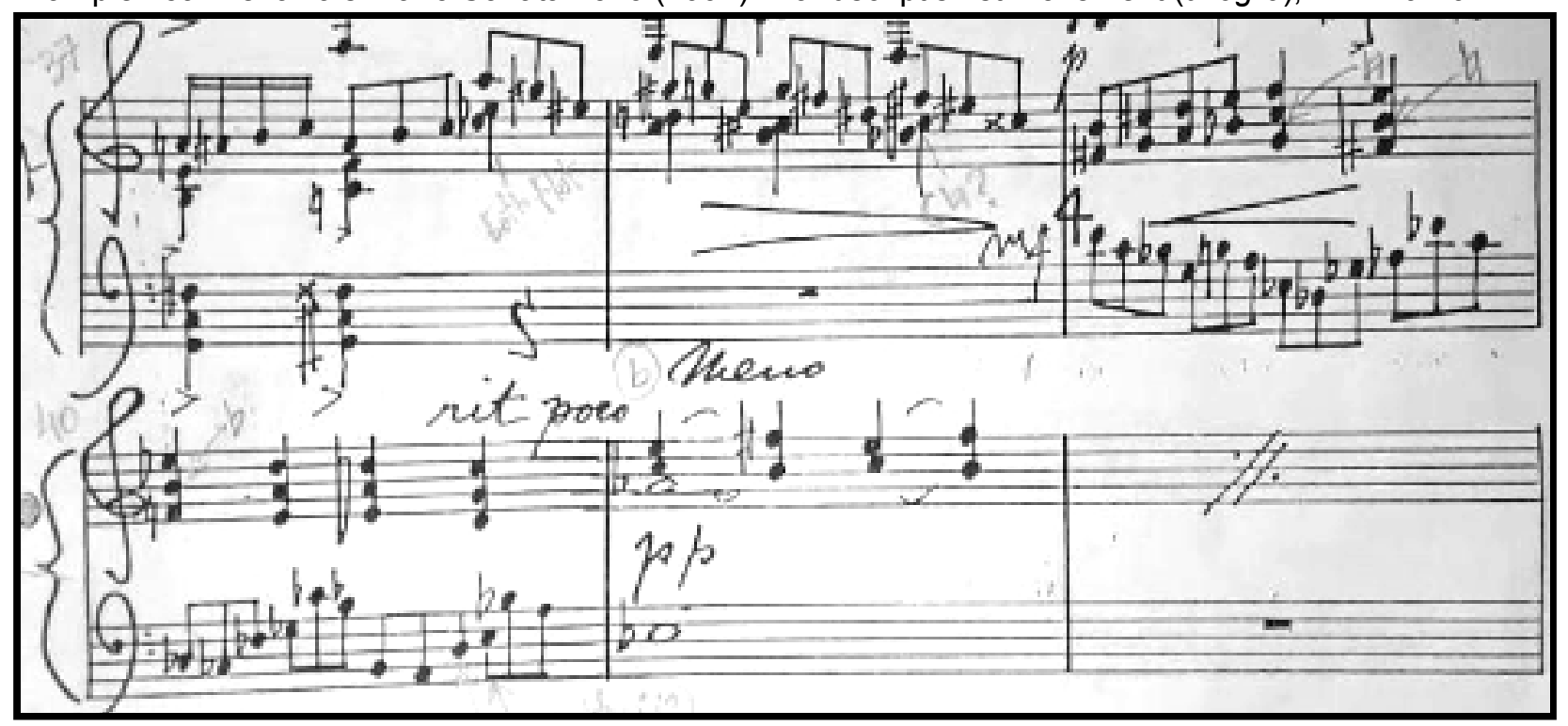

Example 15b: Penalva's Piano Sonata no. 3 (1991). Manuscript's 1st movement (allegro), mm. 37-42. Development's transition (mm. 39-40). 


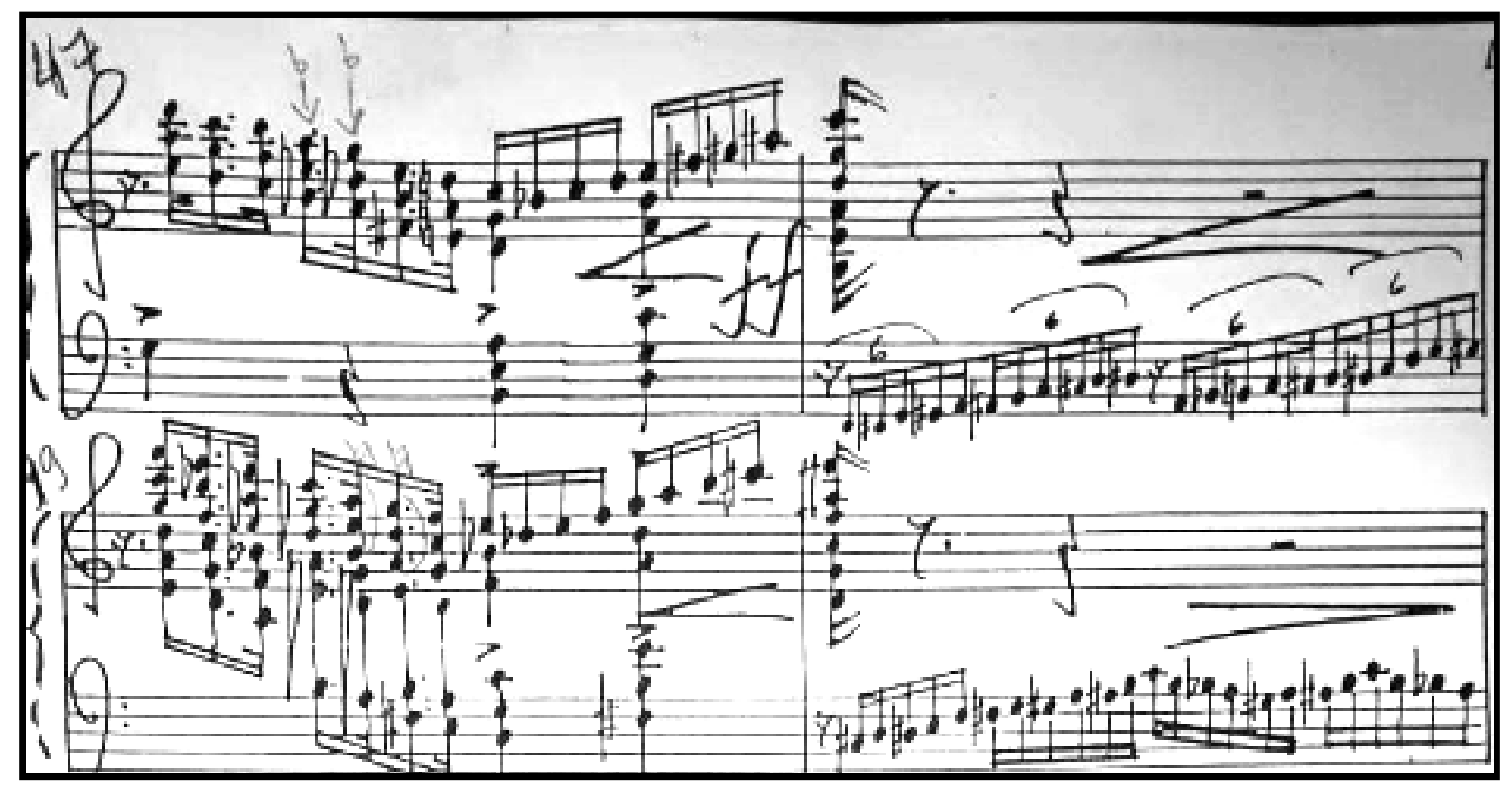

Example 16: Penalva's Piano Sonata no. 3 (1991). Manuscript's 1st movement (allegro), mm. 47-50). 


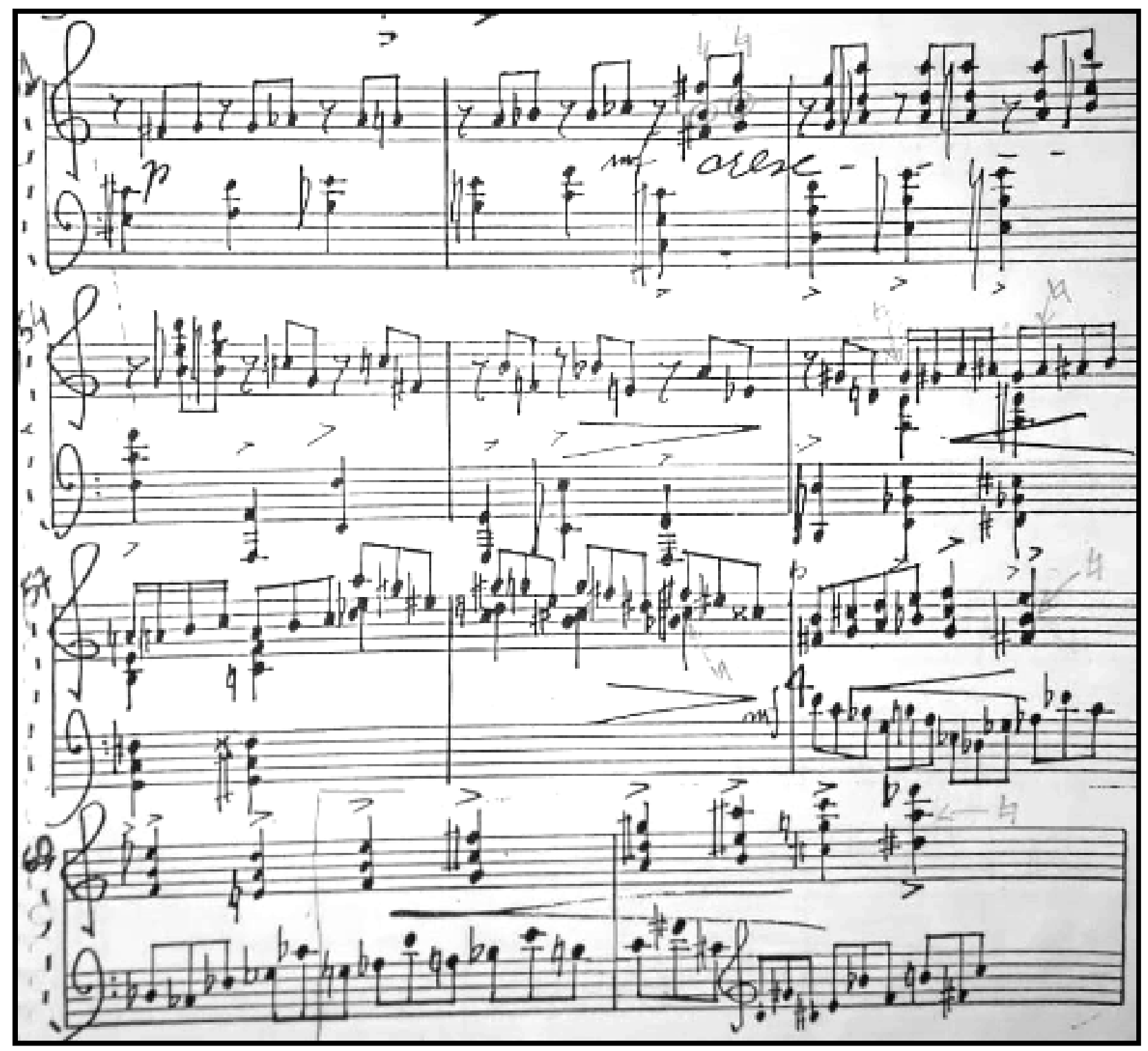

Example 17: Penalva's Piano Sonata no. 3 (1991). Manuscript's 1st movement (allegro), mm. 51-61.

The recapitulation opens with a modified theme $\mathbf{A}$. This time, it spans four measures instead of five, employing the initial rhythmic motif, and minor 2 nds and diminished 5ths as melodic intervals. Essentially, both of the $\mathbf{A}$ themes from the exposition and the recapitulation resemble each other due to their melodic progression by perfect 4 ths (ex. 18, mm. 62-65). 
The remaining parts of the recapitulation keep the same structures as they have in the exposition, with the exception of the last chord in measure 91 (ex. 19).

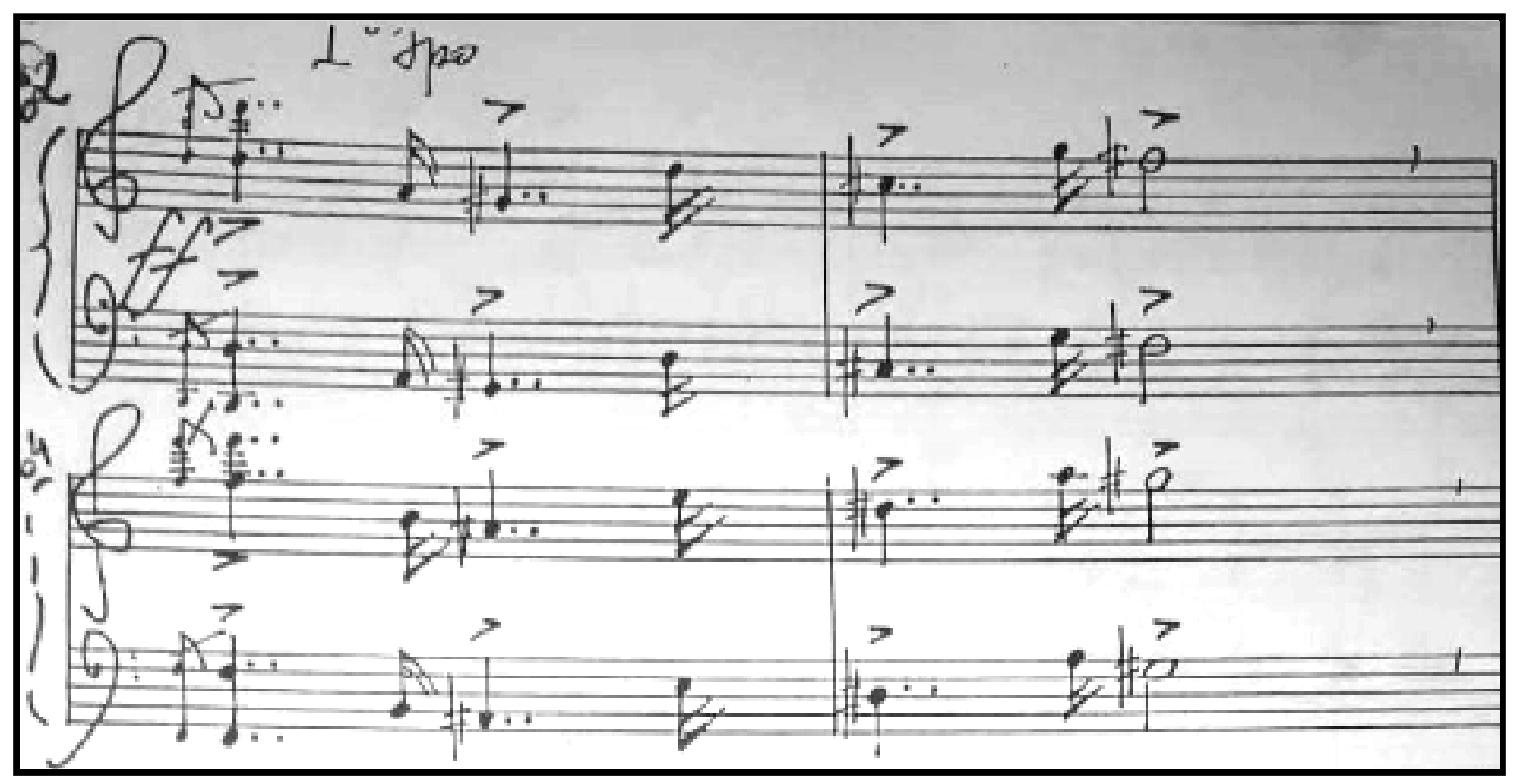

Example 18: Penalva's Piano Sonata no. 3 (1991). Manuscript's 1st movement (allegro), mm. 62-65.

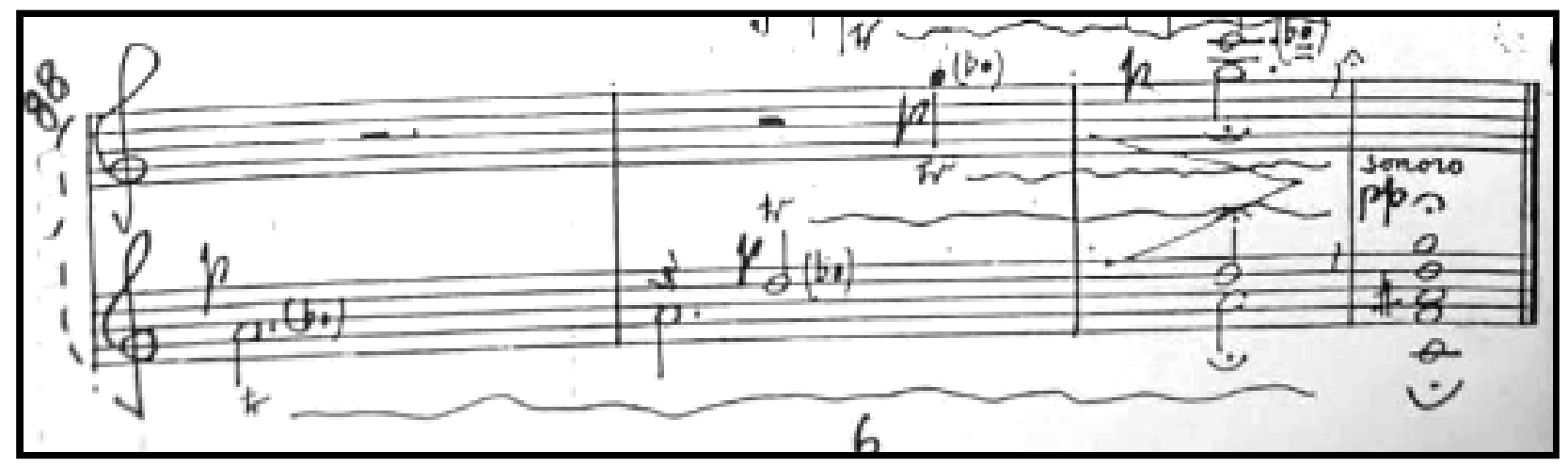

Example 19: Penalva's Piano Sonata no. 3 (1991). Manuscript's 1st movement (allegro), mm. 88-91. 


\section{Andante}

A-B-A
A $[\mathbf{A} 1(\mathrm{~mm} .1-7)$ A2 (mm. 8-14)]
B (mm. 15-28)
$A^{\prime}(\mathrm{mm} .29-43)$

The second movement andante can be divided into two main parts, with a modified return of part one. Its form is A-B-A'. This movement is strongly related to the first movement Allegro, but mainly to its development.

As the outline indicates, section $\mathbf{A}$ (ex. 1, mm. 1-14) also can be divided into two distinct subsections, A1 (mm. 1-7); and A2 (mm. 8-14).

Section A1 utilizes distinct ideas: an expressive, melodic theme in polyphonic and harmonic textures (ex. 1, mm. 1-5), and a resolute, rhythmic theme (ex. 3, mm. 6-7). The expressive, melodic theme in mm.1-5 uses initial motifs in minor 2 nds and 3rds in both the inner and top voices of the right hand (ex. 1, mm. 1-3). These are taken from the allegro's triplets in the development's transition (ex. 2, mm. 38). The energetic theme in mm. 6-7 is derived from the strong rhythm of the Allegro's initial motif (ex. 4).

Section A2 presents a chromatic melodic line in the top voice, spiced with dynamic accents (ex. 5, mm. 8-14). In the following measures, there are many reminders of the allegro's development section. In the two first measures, for instance (ex. 5, mm. 8-9), chords in the right hand resemble the texture of Section D2 of the Allegro's development (ex. 6, mm. 41-42). Next, chromatic ascending quartal chords in 
the right hand (ex. 5, m. 10) also resemble the descending chords in the Allegro's development (ex. 6, mm. 39-40). As in the initial melodic line of $\mathbf{A} 1$, the bass melodic line which accompanies A2 (ex. 5, mm. 8-11) includes some melodic intervals resembling the triplets motifs in the Allegro's development section (ex. 2, m. 38). Other materials clearly taken from the first movement's development are the ascending and descending chromatic scale lines in both hands (sometimes written in single lines, but other times doubled in 3rds (ex. 5, mm. 11-14)) and the use of whole-tone scales (ex. 5, m. 11).

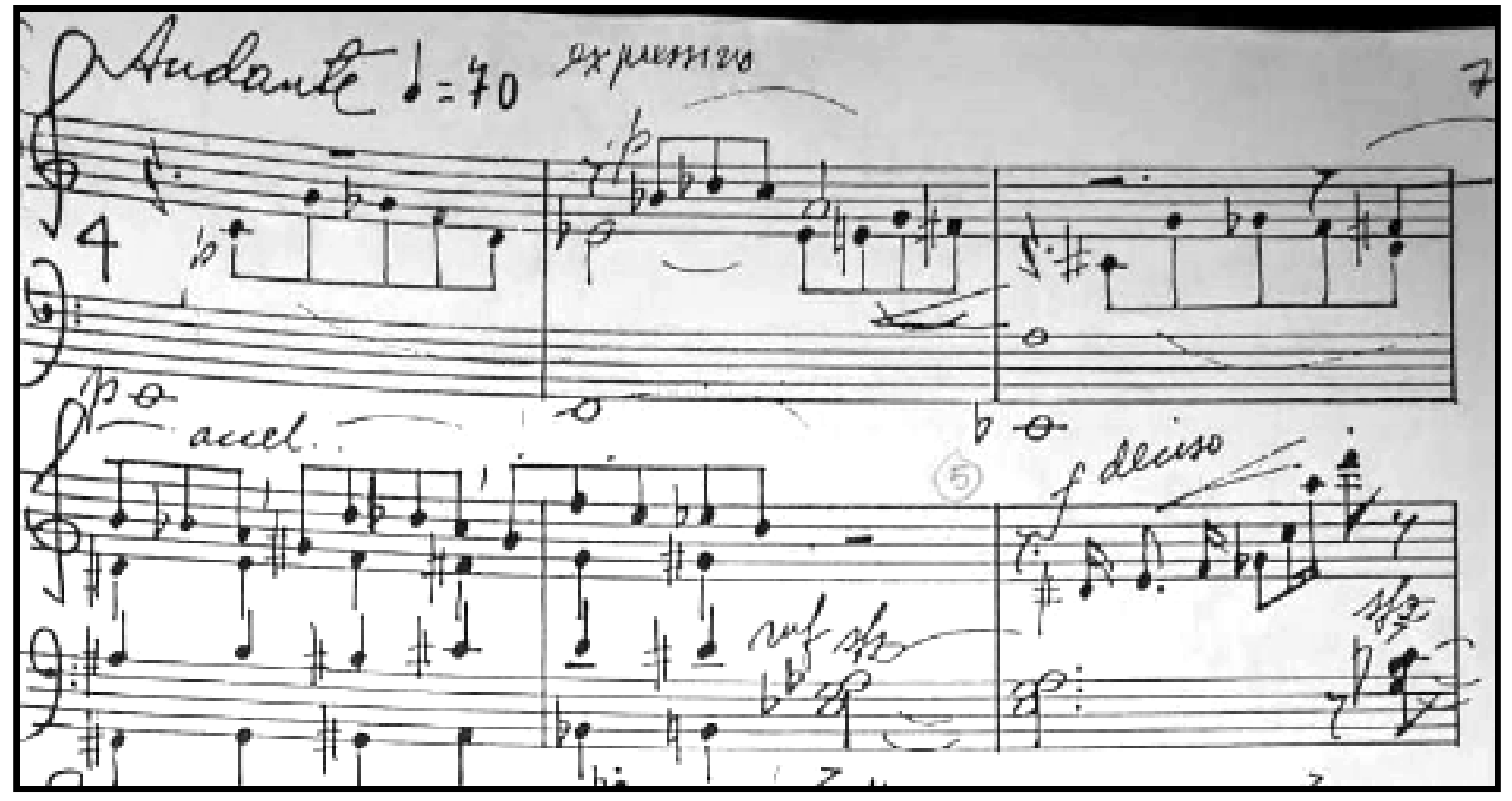

Example 1: Penalva's Piano Sonata no. 3 (1991). Manuscript's 2nd movement (andante), mm. 1-6.

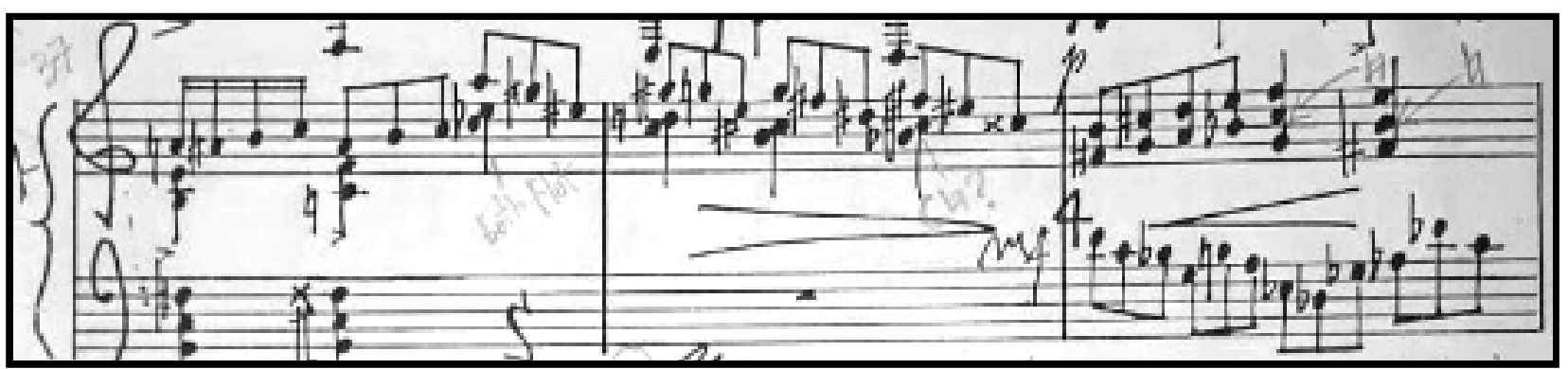

Example 2: Penalva's Piano Sonata no. 3 (1991). Manuscript's 1st movement (allegro), mm. 37-39. Development's transition. 


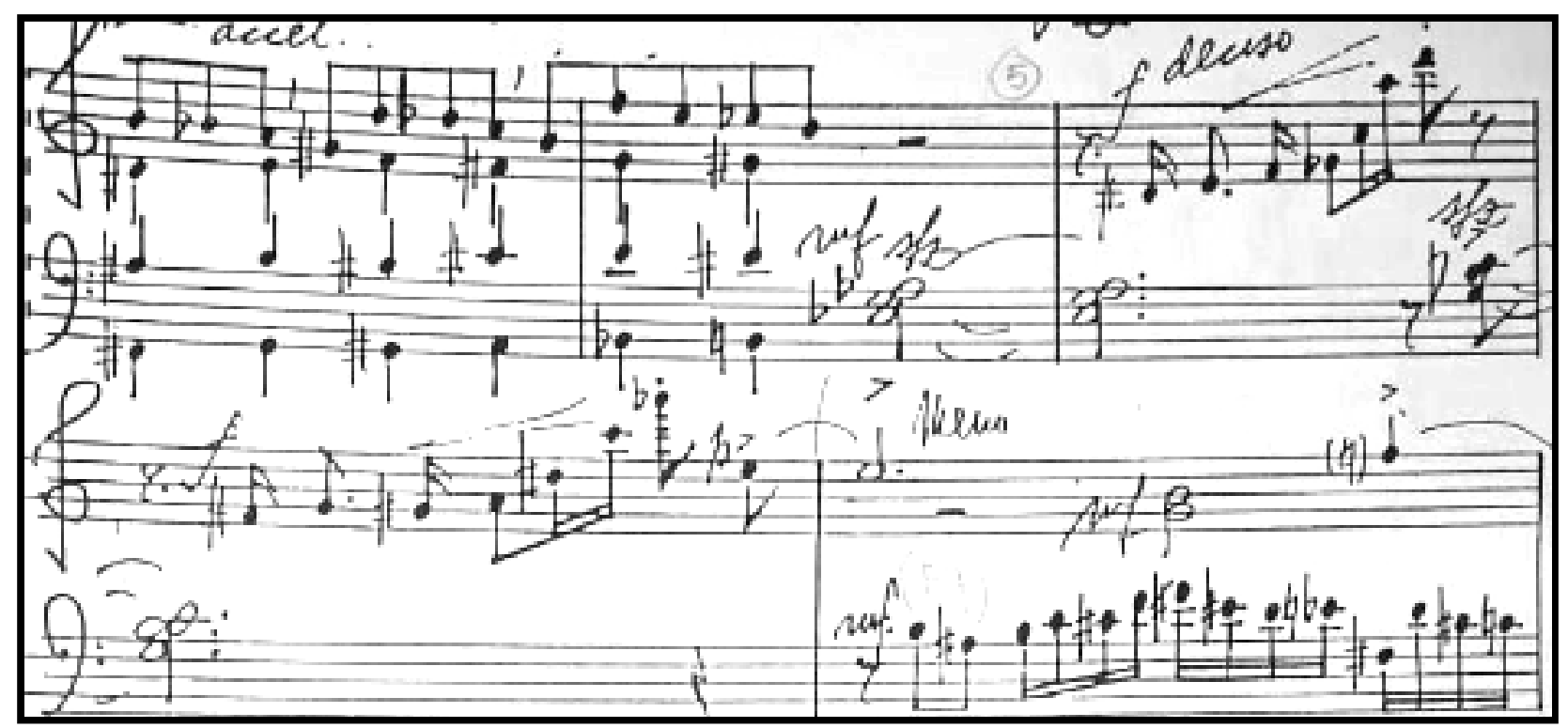

Example 3: Penalva's Piano Sonata no. 3 (1991). Manuscript's 2nd movement (andante), mm. 4-8.

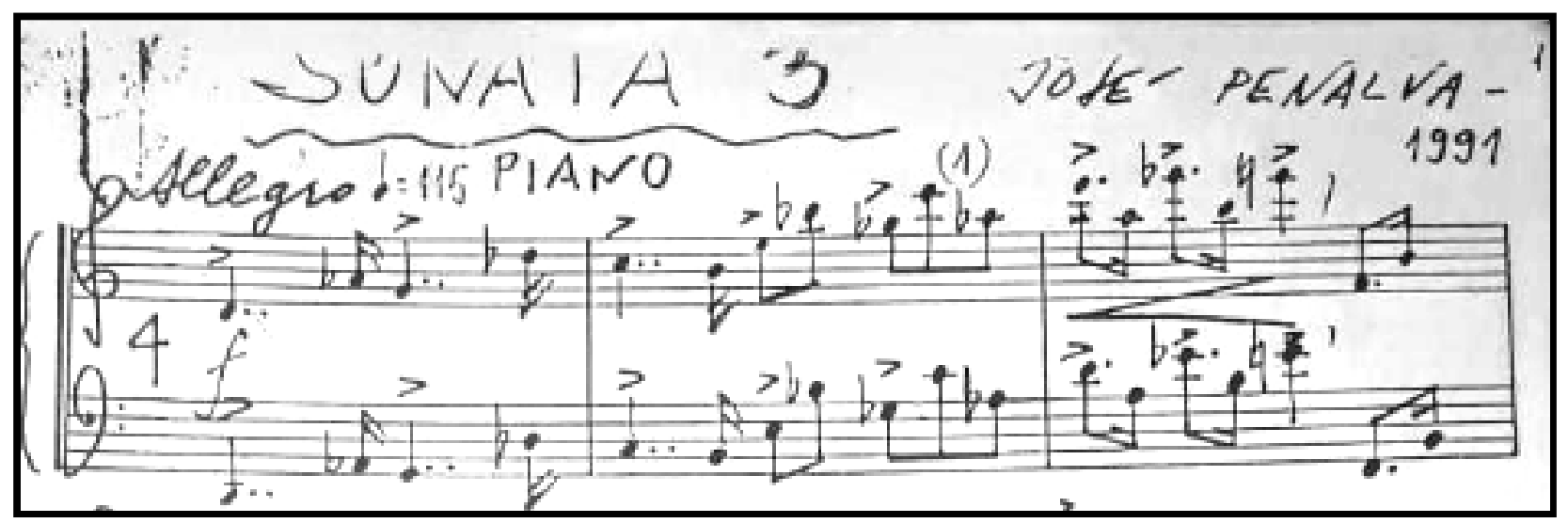

Example 4: Penalva's Piano Sonata no. 3 (1991). Manuscript's 1st movement (allegro), mm. 1-3. 


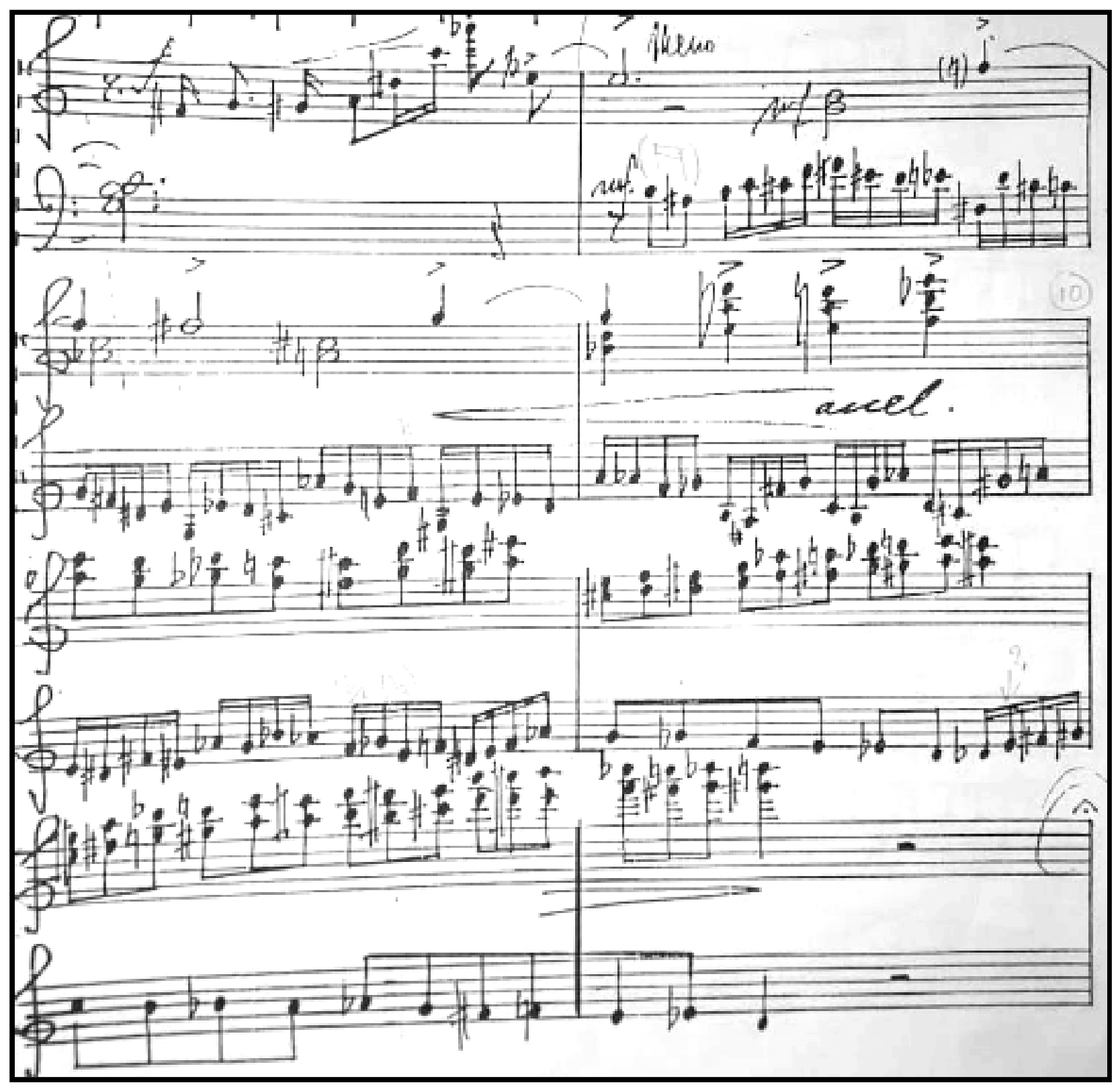

Example 5: Penalva's Piano Sonata no. 3 (1991). Manuscript's 2nd movement (andante), mm. 7-14. 


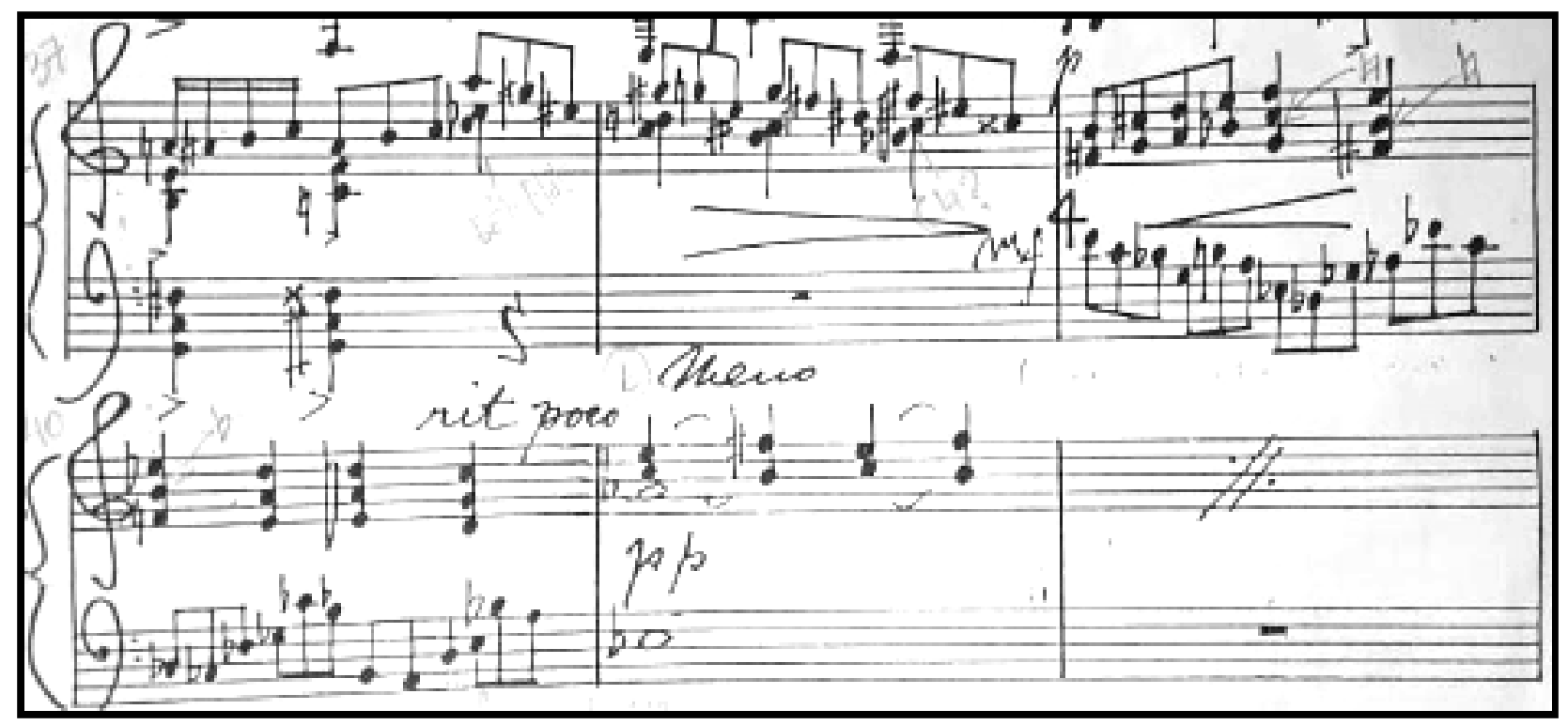

Example 6: Penalva's Piano Sonata no. 3 (1991). Manuscript's 1st movement (allegro), mm. 37-42.

Little by little, section B ( $\mathrm{mm} .15-28)$ becomes more dense and musically rich. It also includes many elements of the first-movement Allegro. For example, its initial melodic theme (ex. 7, mm. 16-17) borrows material from thematic motifs of section $\mathbf{A}$, built on ascending 2nds and 3rds; as previously discussed, this matches the material of Allegro's development, (ex. 6, m. 38). Other related compositional elements found in section B include the use of simultaneous block 2nds (ex. 7, m. 15), ascending and descending chromatic scales (ex. 8, m. 22), wavy melodic lines (ex. 9, mm. 25-26), and recalling the initial rhythmic motif of the Allegro's theme $\mathbf{A}$ (ex. 8, m. 20-21).

The next section is virtually the same as section $\mathbf{A}$ again, except that, in several measures at the very beginning (ex. 10, m. 29), there is a mixture of the second motive of the initial theme (ex. 1, m. 2) and the accompaniment in 10ths (ex. 1, m. 4). Also, the Andante finishes in a polyphonic texture by evoking both initial motifs of sections $\mathbf{A}$ and B (ex. 11, mm. 41-43). 


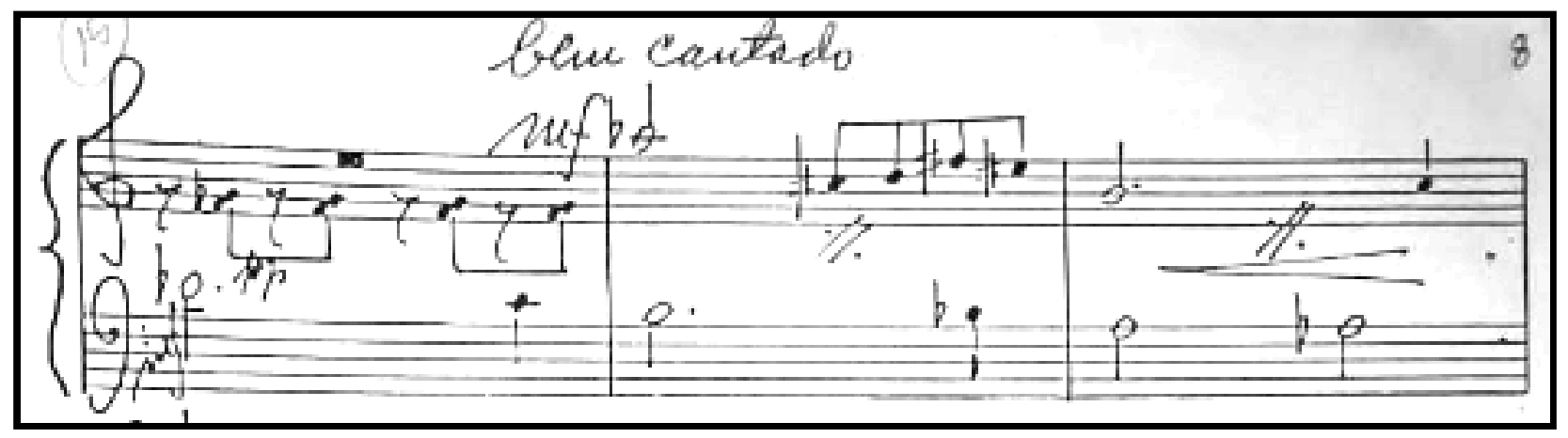

Example 7: Penalva's Piano Sonata no. 3 (1991). Manuscript's 2nd movement (andante), mm. 15-17.

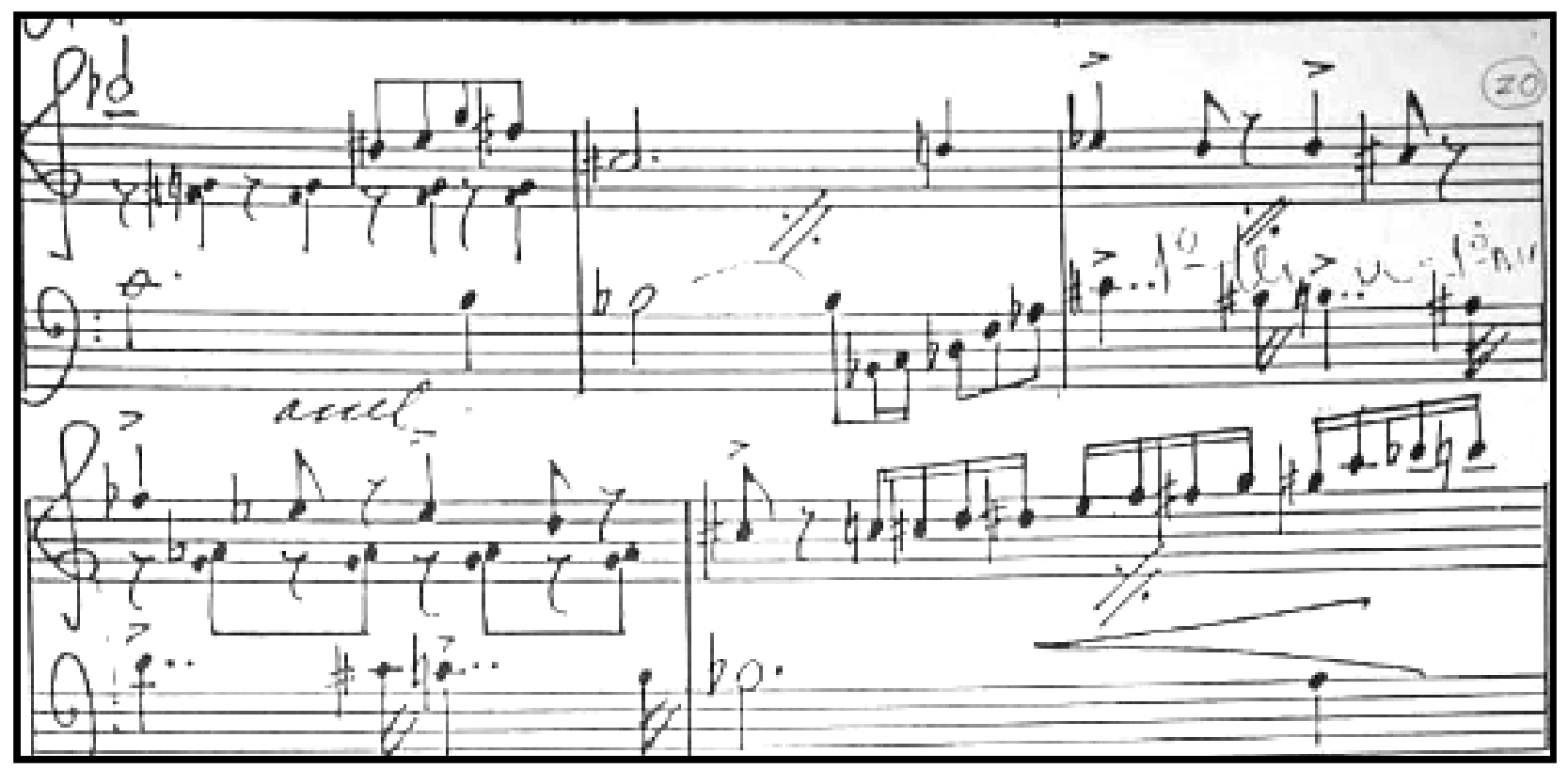

Example 8: Penalva's Piano Sonata no. 3 (1991). Manuscript's 2nd movement (andante), mm. 18-22.

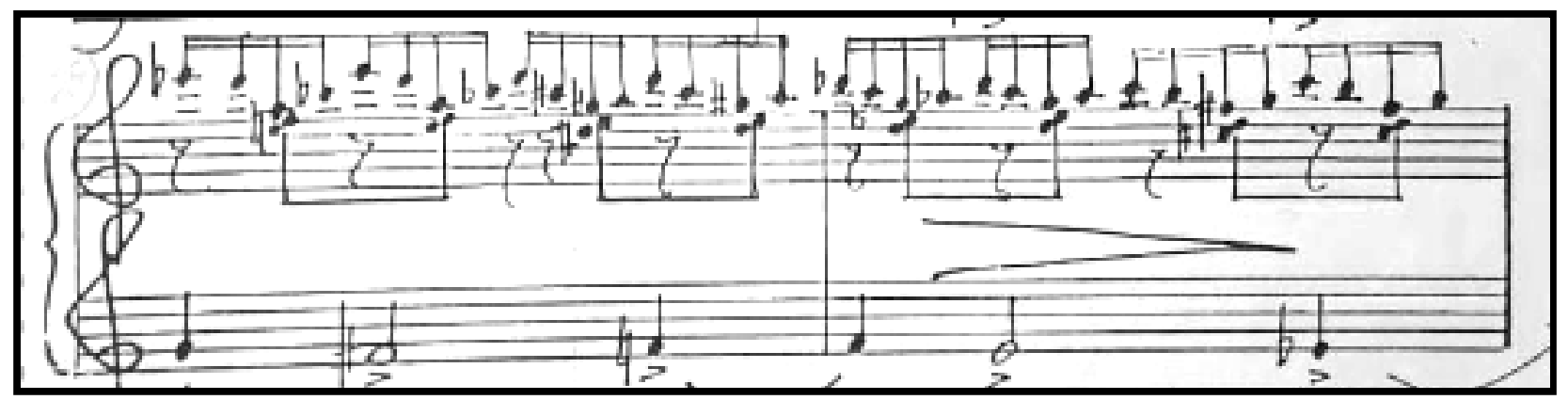

Example 9: Penalva's Piano Sonata no. 3 (1991). Manuscript's 2nd movement (andante), mm. 25-26. 


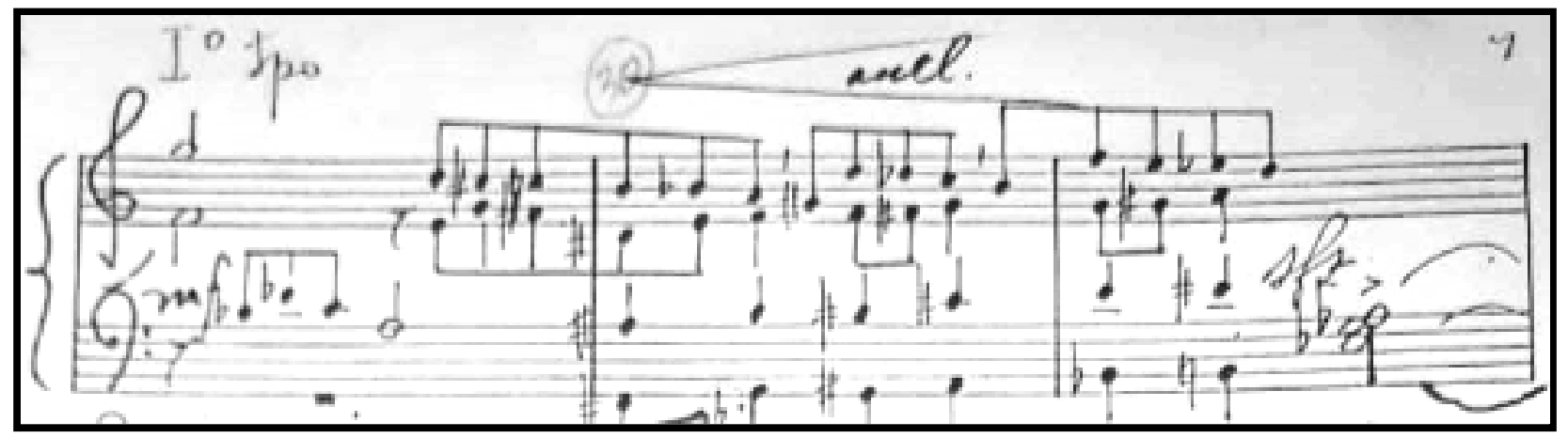

Example 10: Penalva's Piano Sonata no. 3 (1991). Manuscript's 2nd movement (andante), mm. 29-31.

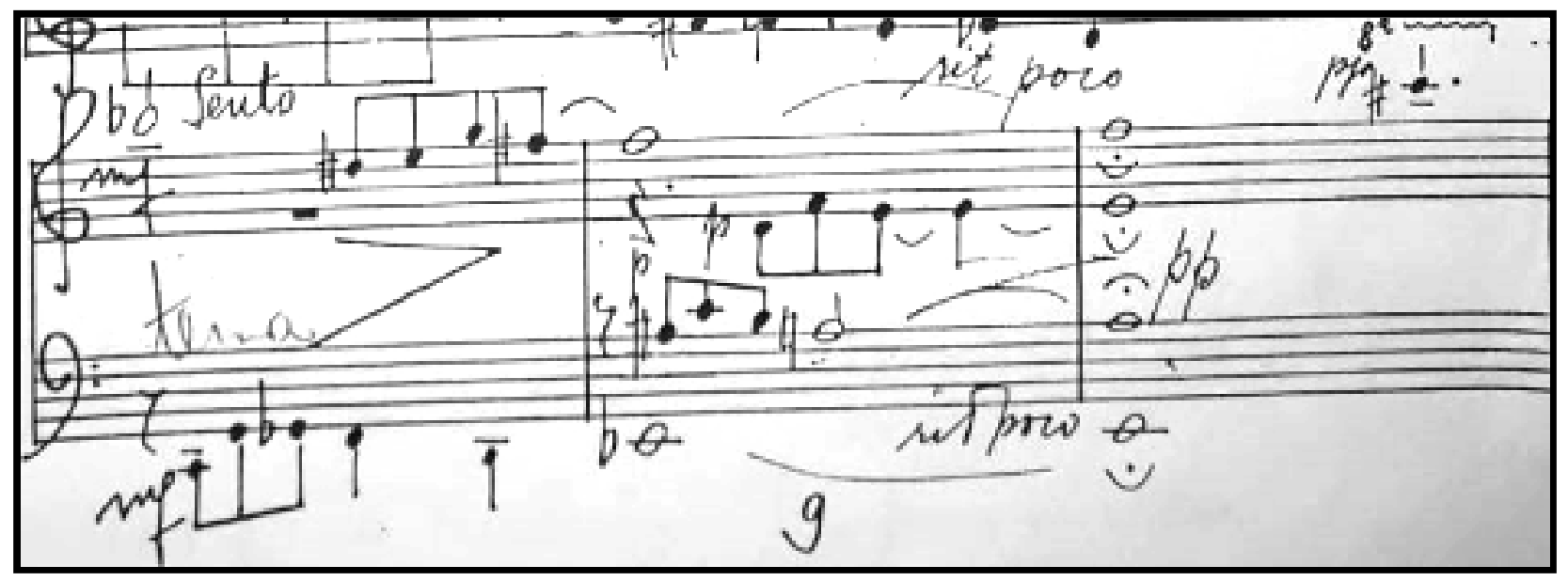

Example 11: Penalva's Piano Sonata no. 3 (1991). Manuscript's 2nd movement (andante), mm. 41-43.

\section{Agitato-Rondó}

\section{A-B-A-C-A-D-A-Coda}

A Refrain (mm. 1-13)

B Episode I (mm. 14-26)

A Refrain (mm. 1-13)

C Episode II (mm. 27-60)

A Refrain (mm. 1-13)

D Episode III (mm. 61-90)

A Refrain (mm. 91-97)

Coda (mm. 98-111) 
Like other movements of Penalva's sonatas, this movement is classically structured, specifically as a rondo with contrasting parts that return to the main refrain. It is a technically demanding movement. Alexandre Gonçalves writes (Gonçalves, 2009, p. 112):

O terceiro movimento pode ser considerado o mais virtuosístico das três Sonatas para piano. (The third movement can be considered the most virtuosic movement among the three piano sonatas.)

The form of the agitato-rondó is A-B-A-C-A-D-A-Coda. At the very beginning, the composer writes the following direction in order to avoid having the refrain be grouped in triplets: "Note-se que estas três notas iguais não fazem quiáltera." ("Observe that these three even notes do not make triplets." $)^{64}$

The refrain (ex. 1, mm. 1-13) has an introductory rhythmic and energetic character, with no melodic lines. Its rhythmic and percussive texture increasingly thickens, using previously employed materials, like 2 nds, augmented 4ths, and quartal harmonies. It employs a repeated note, D3, after which more pitches are added to the texture a little at a time. Afterwards, a wavy melodic figuration of perfect and augmented 4ths, later enhanced with harmonic 4ths, helps to smooth the essentially percussive and rhythmic nature of the refrain.

${ }^{64}$ Penalva's footnote writings, Sonata no. 3, manuscript, p. 10. 


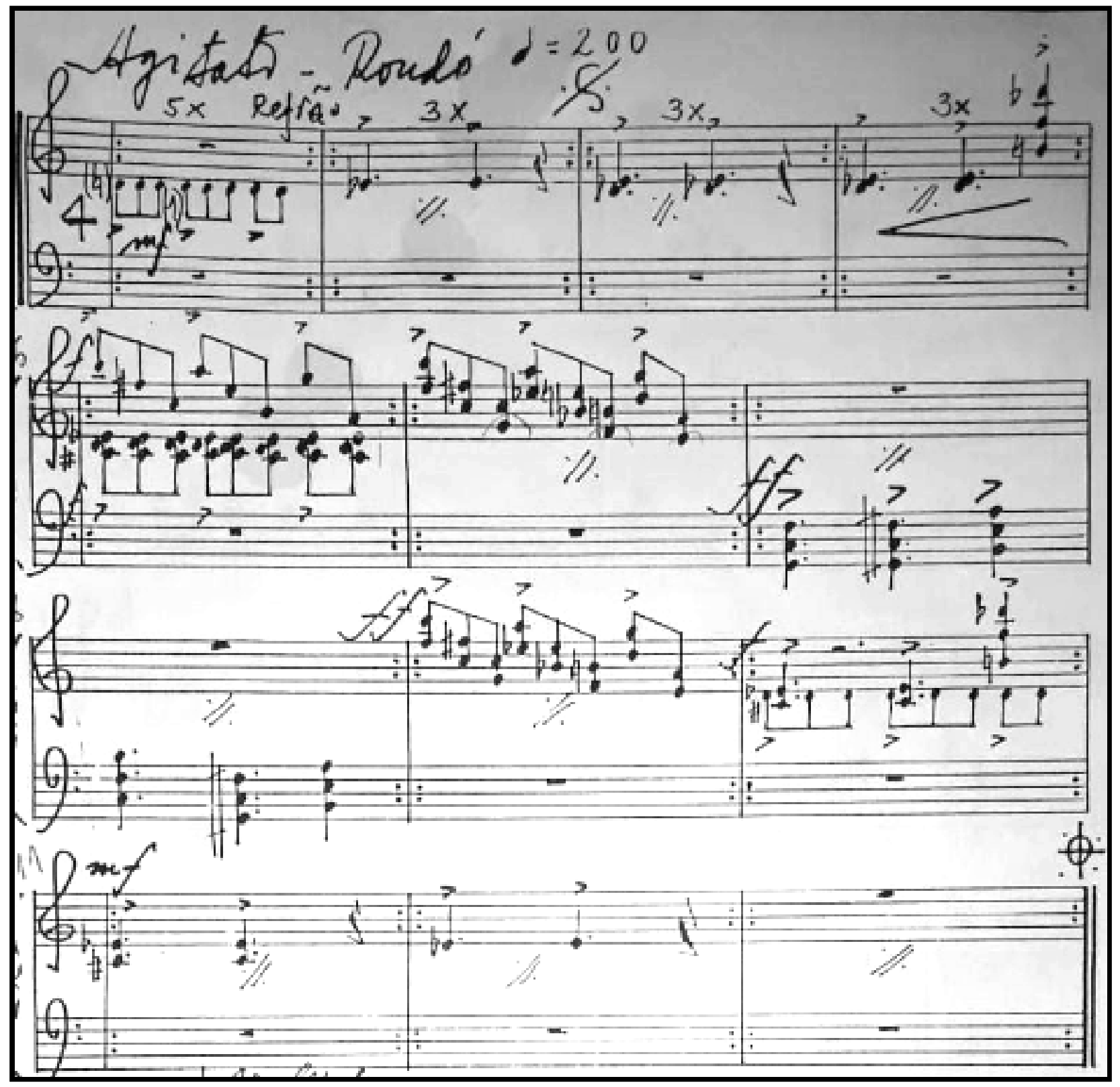

Example 1: Penalva's Piano Sonata no. 3 (1991). Manuscript's 3rd movement (agitato-rondó), mm. 1-13.

Episode I (mm. 14-26) has a tempo marking of quarter $=80$, much slower than the opening material (quarter $=200) .{ }^{65}$ It starts with a contrasting four-measure melodic theme, which will be elaborated in different ways throughout the entire episode (ex. 2, mm. 14-17).

${ }^{65}$ Dottori's edition suggests a more achievable tempo (quarter $=120$ ), rather than Penalva's original quarter $=200$. 


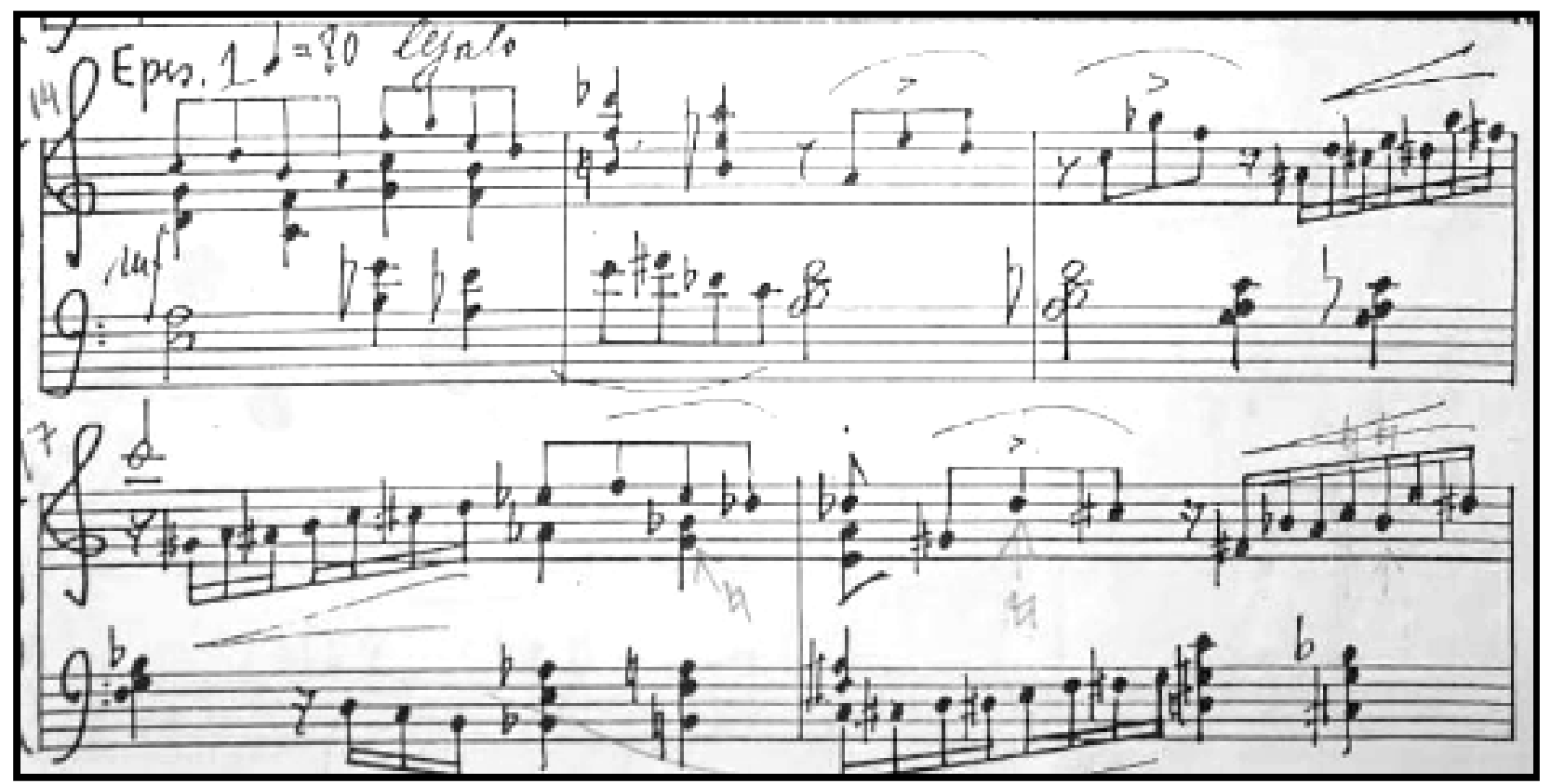

Example 2: Penalva's Piano Sonata no. 3 (1991). Manuscript's 3rd movement (agitato-rondó), mm. 14-18.

EP1-A (mm. 14-19), is the material from which EP1-B is built. In other words, EP1-B (mm. 20-25) is a slight modification of the material in EP1-A. Its modifications include: the initial theme starts in the lower part of the piano instead of in the upper register; the four-note initial motif is rhythmically varied (ex. 3, m. 20); and Penalva adds one final measure, utilizing the previous wavy melodic line on the lower staff and the chromatic-chord descending passage of 5ths and 2nds on the upper staff (ex. 4, m. 25). 


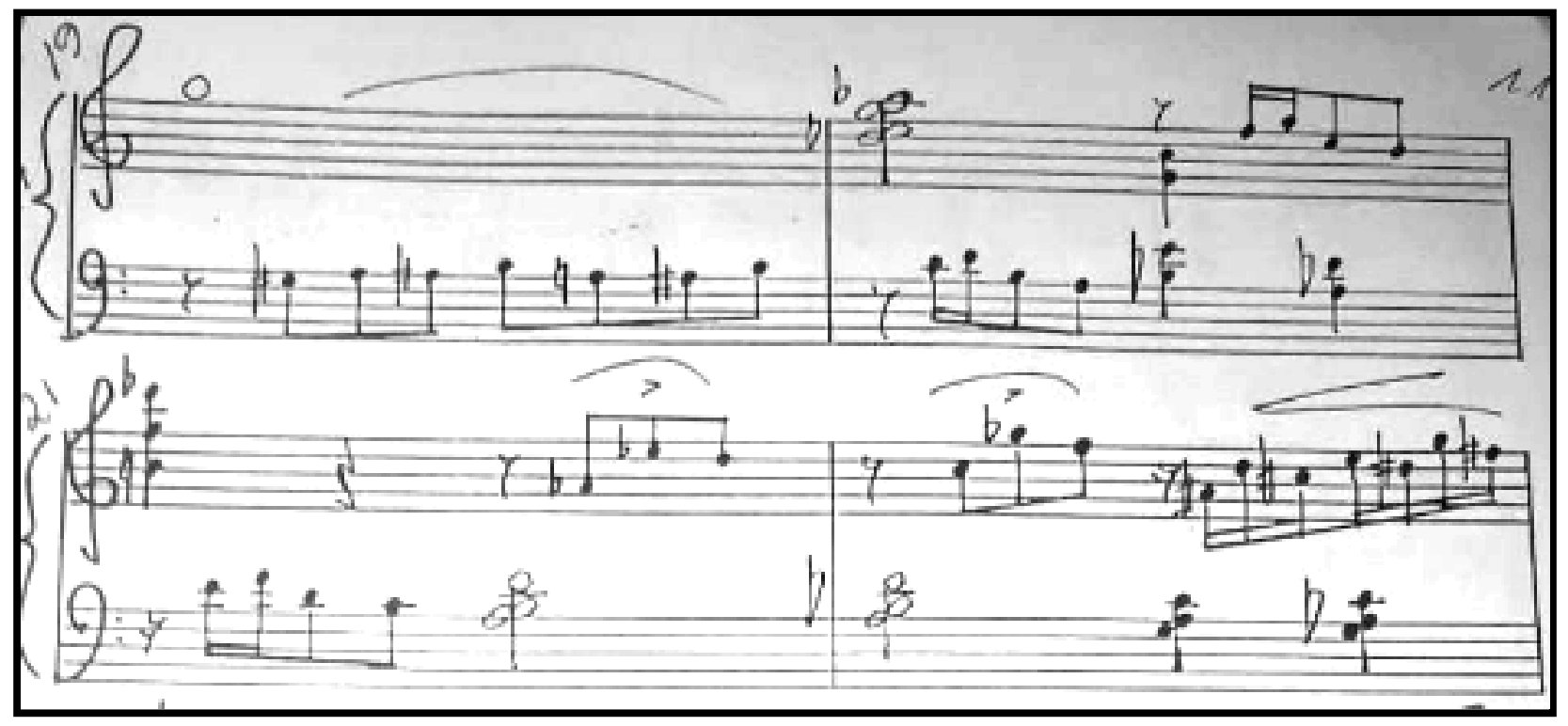

Example 3: Penalva's Piano Sonata no. 3 (1991). Manuscript's 3rd movement (agitato-rondó), mm. 19-22.

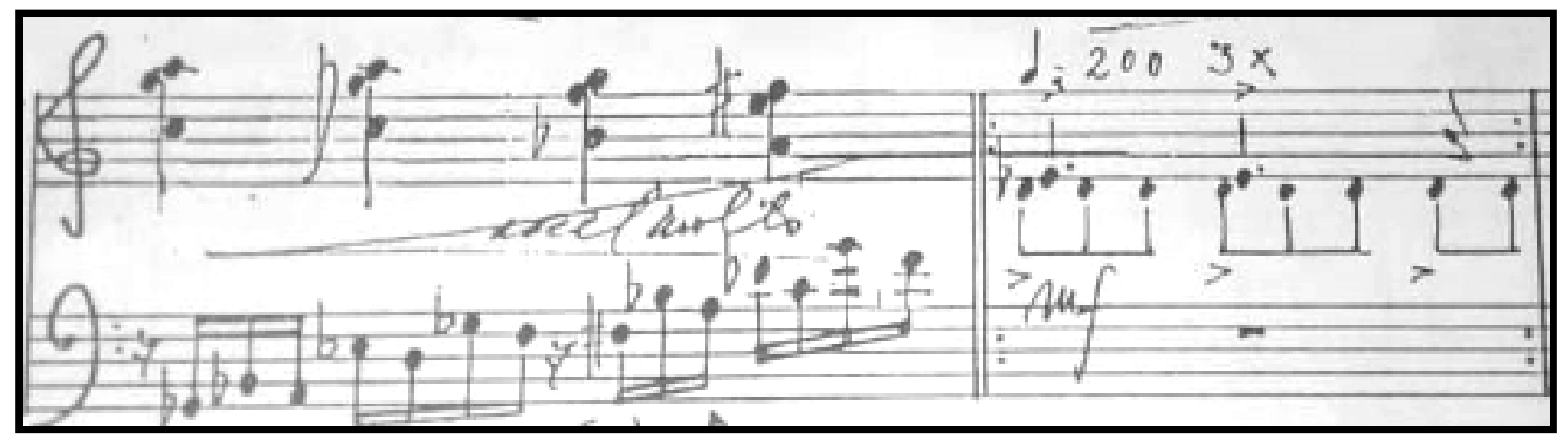

Example 4: Penalva's Piano Sonata no. 3 (1991). Manuscript's 3rd movement (agitato-rondó), mm. 25-26.

After the second occurrence of the rondo's refrain (mm. 1-13), EP2 ensues ( $\mathrm{mm}$. 27-60). It has two main sections, each with two parts: EP2-A1(mm. 27-33), EP2-A2 (mm. 34-44); EP2-B1 (mm. 45-53), EP2-A1' (mm. 54-60). The first part, EP2-B1, is a slower, contrasting section labelled "lento expressivo"; it reveals binary meter. The second section, EP2-A1' (mm. 54-60), returns to EP1's initial tempo and 6/8 meter, with the composer's direction that the eighth-note pulse should remain constant. 
Section EP2-A1 (ex. 5, mm. 27-33) opens with an imitative counterpoint composed from varying qualities of thirds and fourths moving primarily upward (ex. 5). The texture is augmented gradually by the addition of 4 ths to the melodic line, and afterward, by the addition of 7 ths (ex. 5, mm. 30-32). The texture of the left-hand material remains the same.

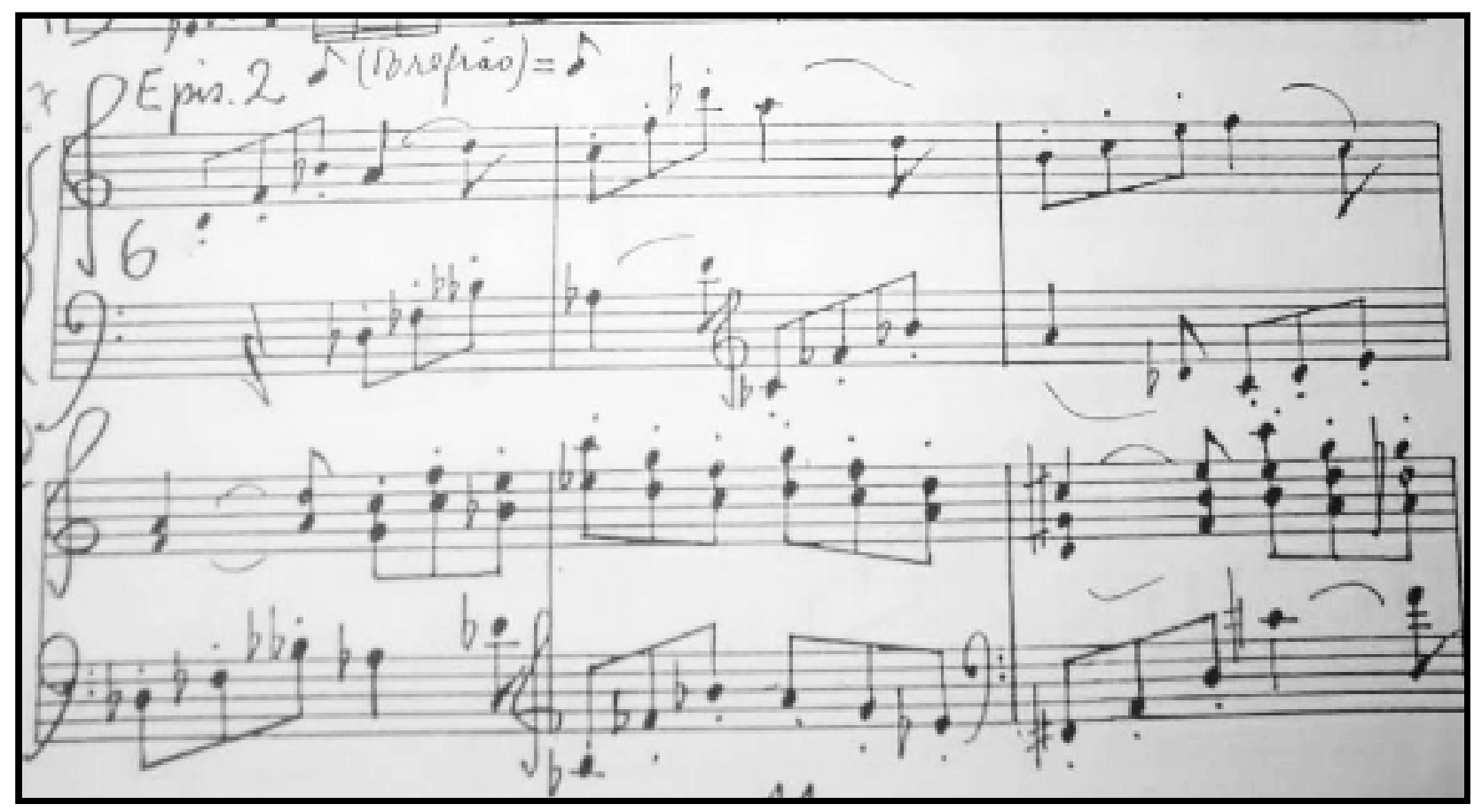

Example 5: Penalva's Piano Sonata no. 3 (1991). Manuscript's 3rd movement (agitato-rondó), mm. 27-32.

By contrast, Section EP2-A2 (ex. 6, mm. 34-44) opens with a homophonic texture comprised of superimposed 4ths over an ostinato bass. It bears some resemblance to the Allegro's theme B (ex. 6, mm. 34-37). The ostinato pattern alternates between the upper and lower regions of the piano, with quartal chords in between (ex. 6, mm. 38-41). In measures 38-40 (ex. 6) Penalva writes an internal rhythmic change, subdividing in groups of two instead of three, and creating a polyrhythmic texture against the left-hand chords that keep the original pulse. 
As EP2-A2 ends, two measures of double-5th ascending scales in both hands prepare for a contrasting second section, EP2- B (ex. 6, mm. 42-44).

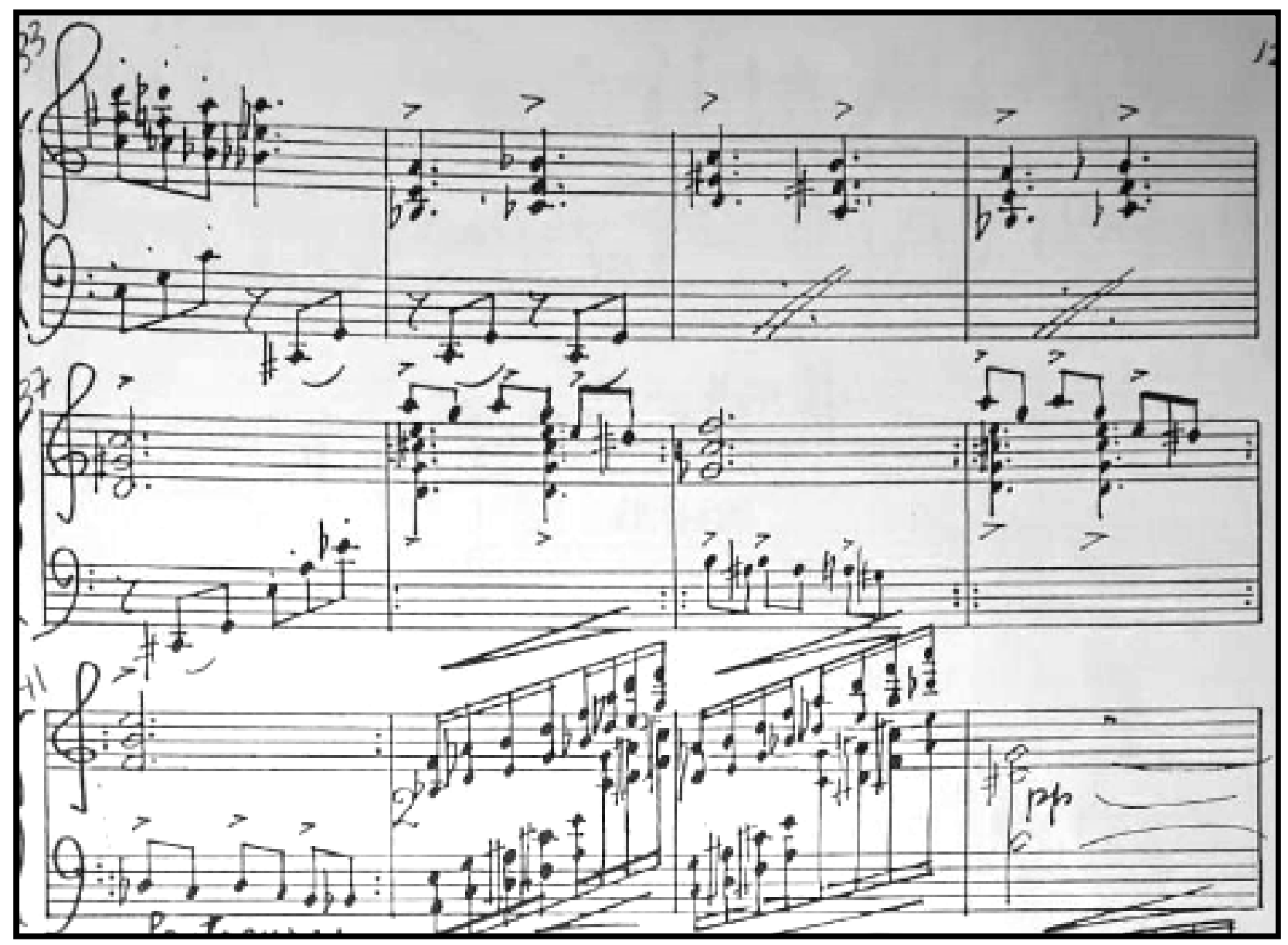

Example 6: Penalva's Piano Sonata no. 3 (1991). Manuscript's 3rd movement (agitato-rondó), mm. 33-44.

Marked by the indication "lento expressivo," the abrupt change of tempo ushers in the beginning of section EP2-B (ex. 7, mm. 45-53). This section can also be divided into two main ideas: the first one, EP2-B1, has a lyrical and melodic character, whose melodic line is built of chromatic intervals and accompanied by chords with longer rhythmic values (ex. 7, mm. 45-48). The second idea, EP2-B2, has a contrasting, rhythmic melodic line with wavy contour, accompanied by a rhythmic, eighth-note ostinato in the left hand. It becomes dynamically and rhythmically stronger via the 
composer's marking, "um pouco mais e bem marcado" ("a little faster and well accentuated") (ex. 7, mm. 45-53). Finally, the main theme from the second episode (EP2-A) is repeated EP2-A1' ( $\mathrm{mm}$. 54-60), before the return of the rondo refrain.

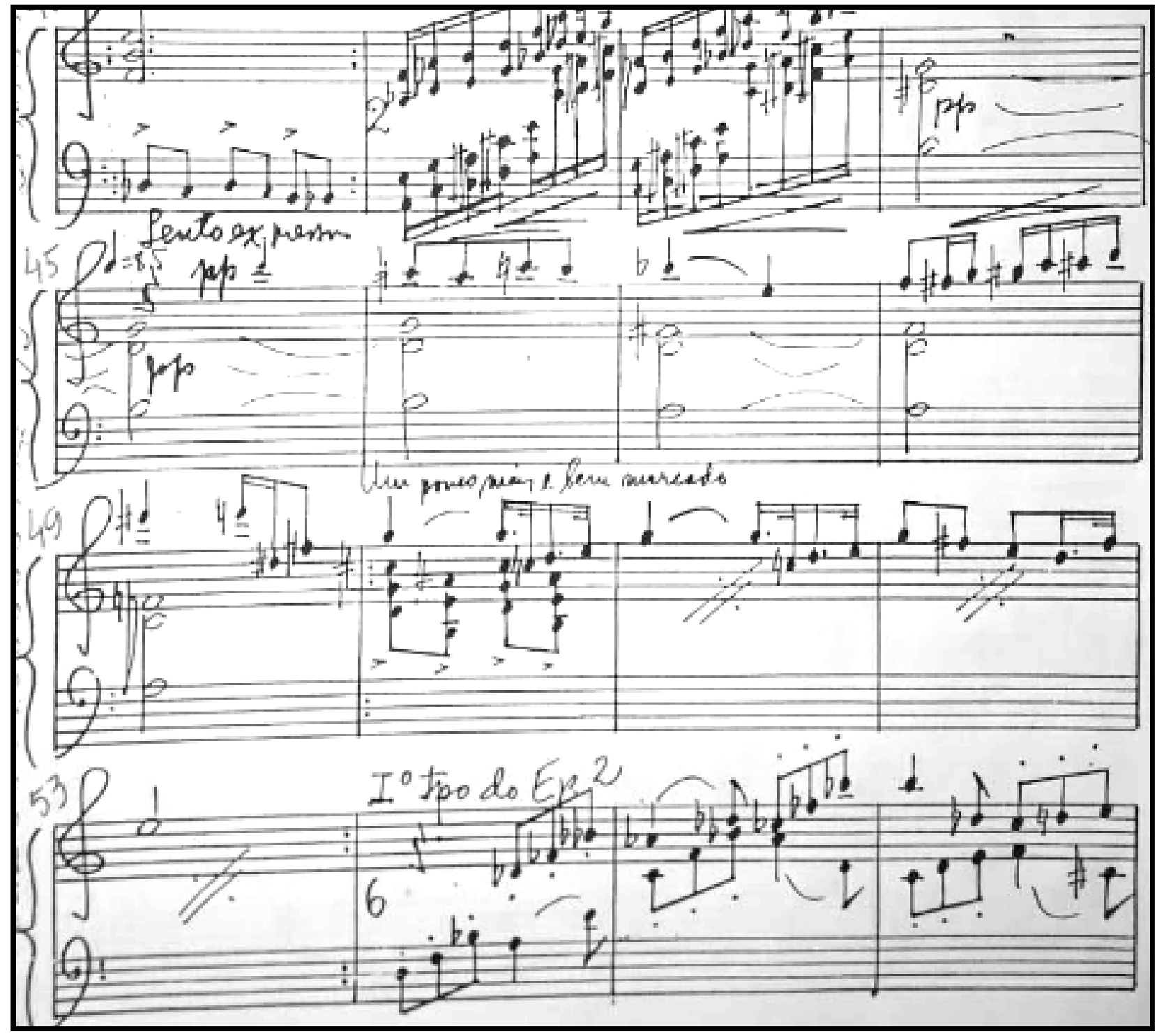

Example 7: Penalva's Piano Sonata no. 3 (1991). Manuscript's 3rd movement (agitato-rondó), mm. 41-56.

Episode III, EP3, (mm. 61-90) has a tempo marking of quarter note $=120$. It starts with an introductory section, EP3-Intro (mm. 61-67), that employs chromaticism, 
2nds, movement one's rhythmic motif, and movement one's chordal ostinato as found in the development (ex. 8, mm. 61-67).

After a brief diminished octave marked ' $f$ ', EP3-Intro begins with an energetic chromatic scale, followed by abrupt tempo and dynamic contrasts (ex. 9, mm. 61-62). After this, eighth-note motifs enter, resembling the initial Allegro's rhythm (ex. 8, mm. 63-64). A cluster of 2nds prepares the following ostinatos, taken from the Allegro's development section (ex. 8, mm. 65-67).

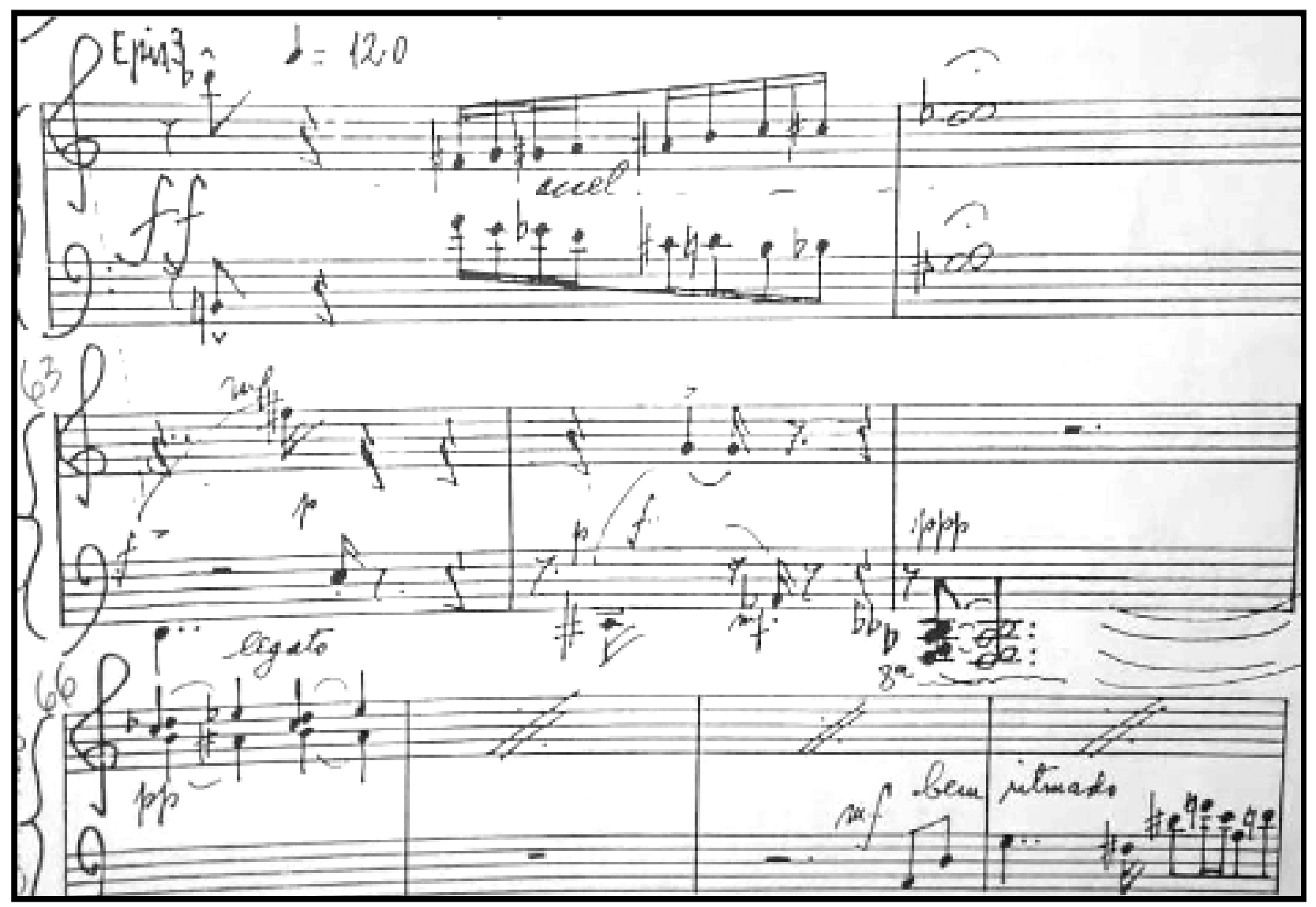

Example 8: Penalva's Piano Sonata no. 3 (1991). Manuscript's 3rd movement (agitato-rondó), mm. 61-67. 


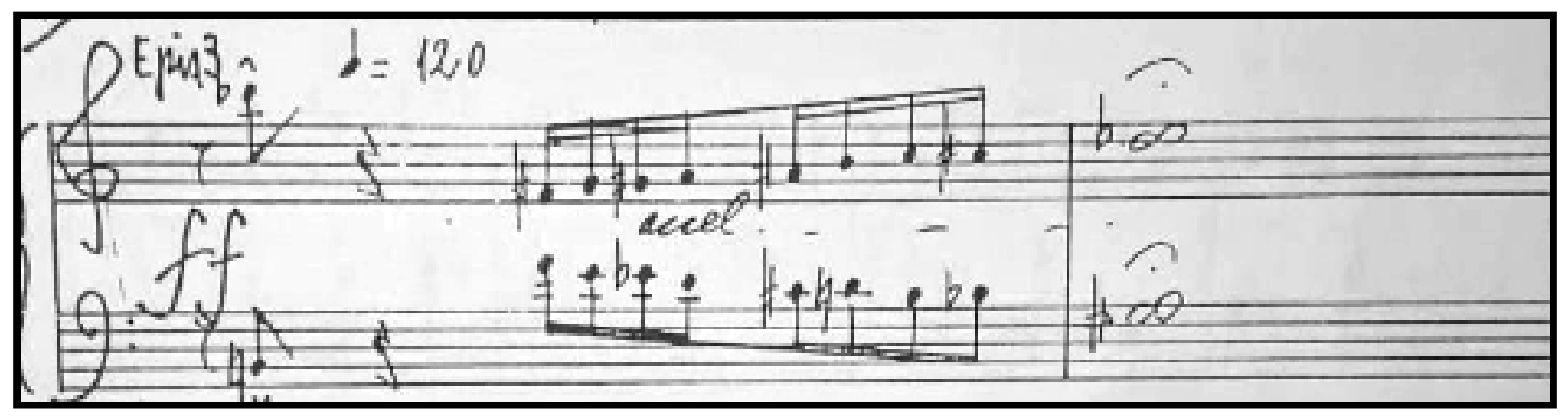

Example 9: Penalva's Piano Sonata no. 3 (1991). Manuscript's 3rd movement (agitato-rondó), mm. 61-62.

EP3-A (mm. 68-76, ex. 10a-10b) presents the first theme, EP3-A1, in the bass line. Its melodic contour resembles that of the first section of the bass line of the Andante (ex. 10a, mm. 68-72); it is repeated literally. Next, a new idea, EP3-B (mm. 77-83) presents material with inverted roles. Now, a melodic line similar to the previous one in the bass appears this time in the upper staff, accompanied by a left-hand parallel-fifth ostinato (ex. 11, mm. 77-83). The musical roles are inverted once again in EP3-B' (mm. 84-90), where the melody of EP3-B is slightly altered and presented in the bassline (ex. 12, mm. 84-90).

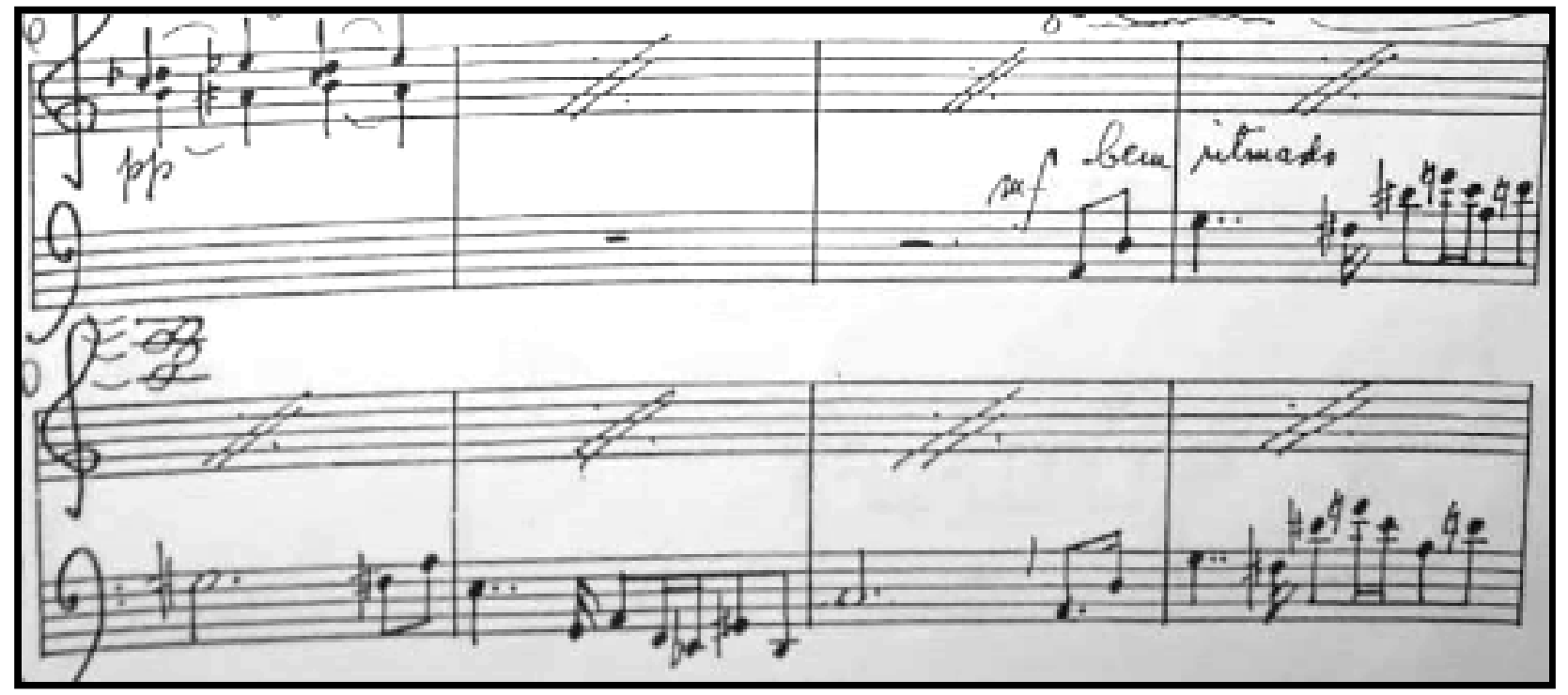

Example 10a: Penalva's Piano Sonata no. 3 (1991). Manuscript's 3rd movement (agitato-rondó), mm. 66-73. 


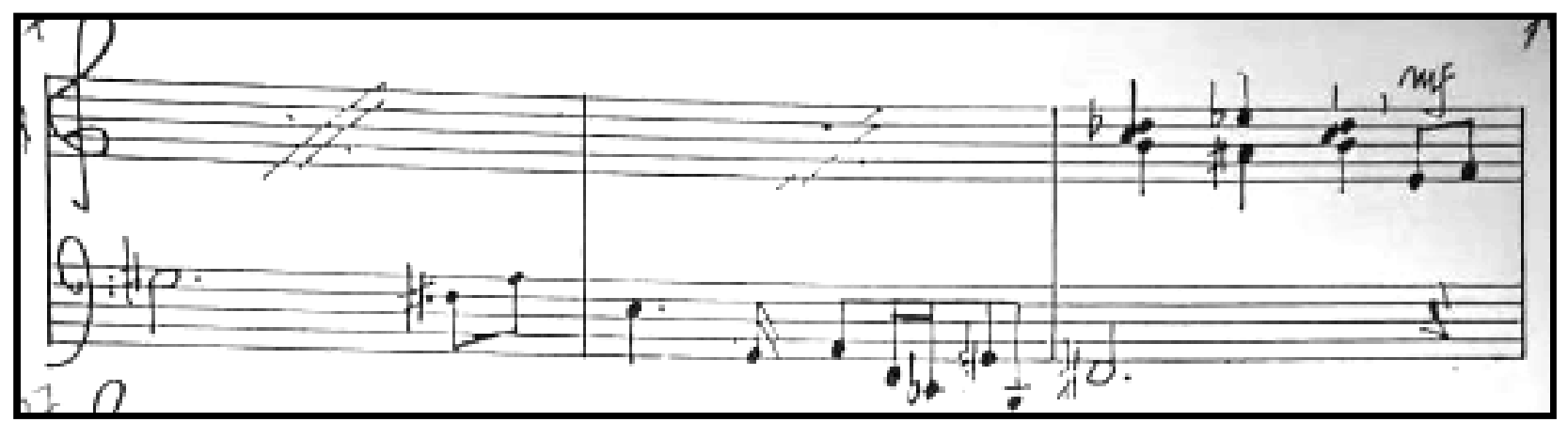

Example 10b: Penalva's Piano Sonata no. 3 (1991). Manuscript's 3rd movement (agitato-rondó), mm. 74-76.

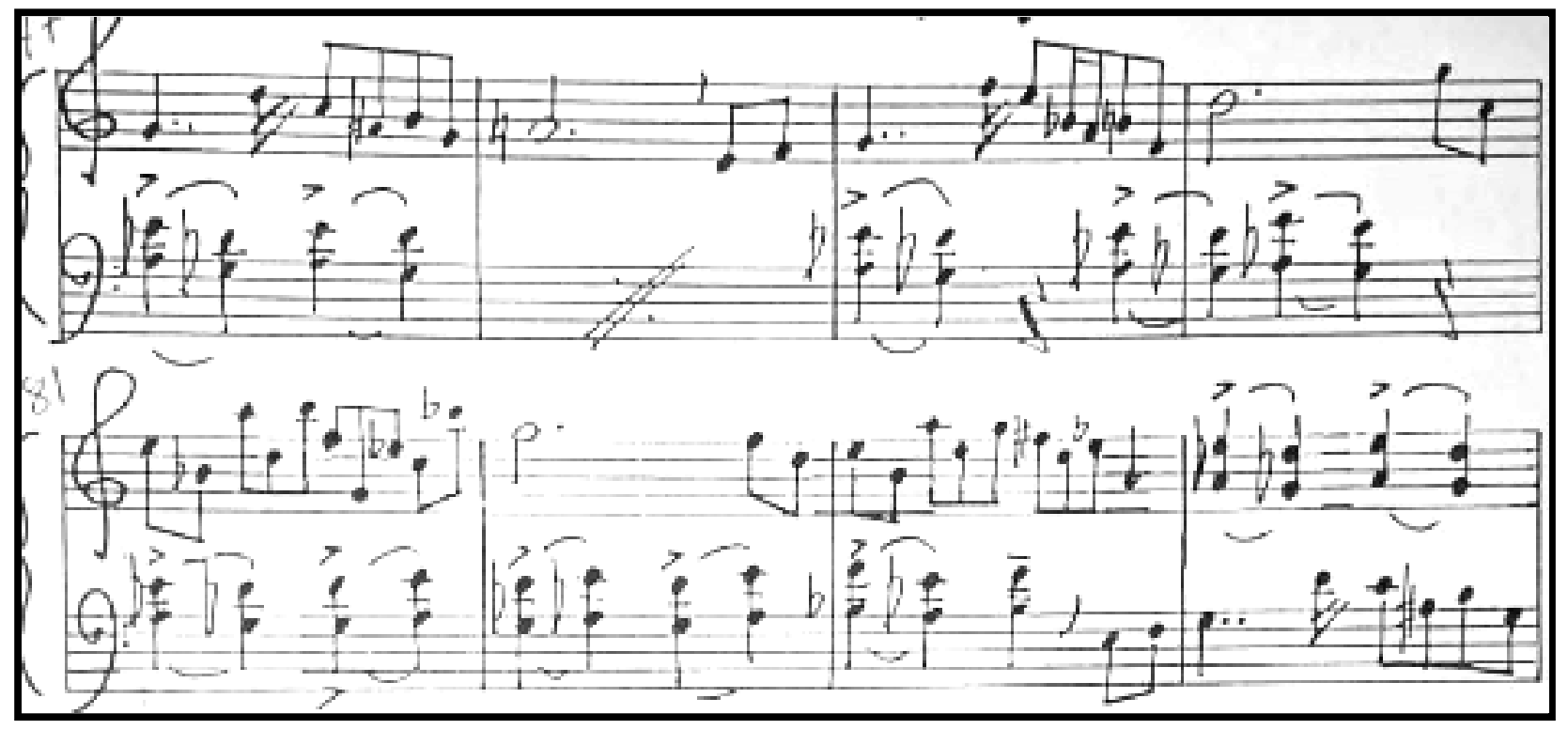

Example 11: Penalva's Piano Sonata no. 3 (1991). Manuscript's 3rd movement (agitato-rondó), mm. 77-84. 


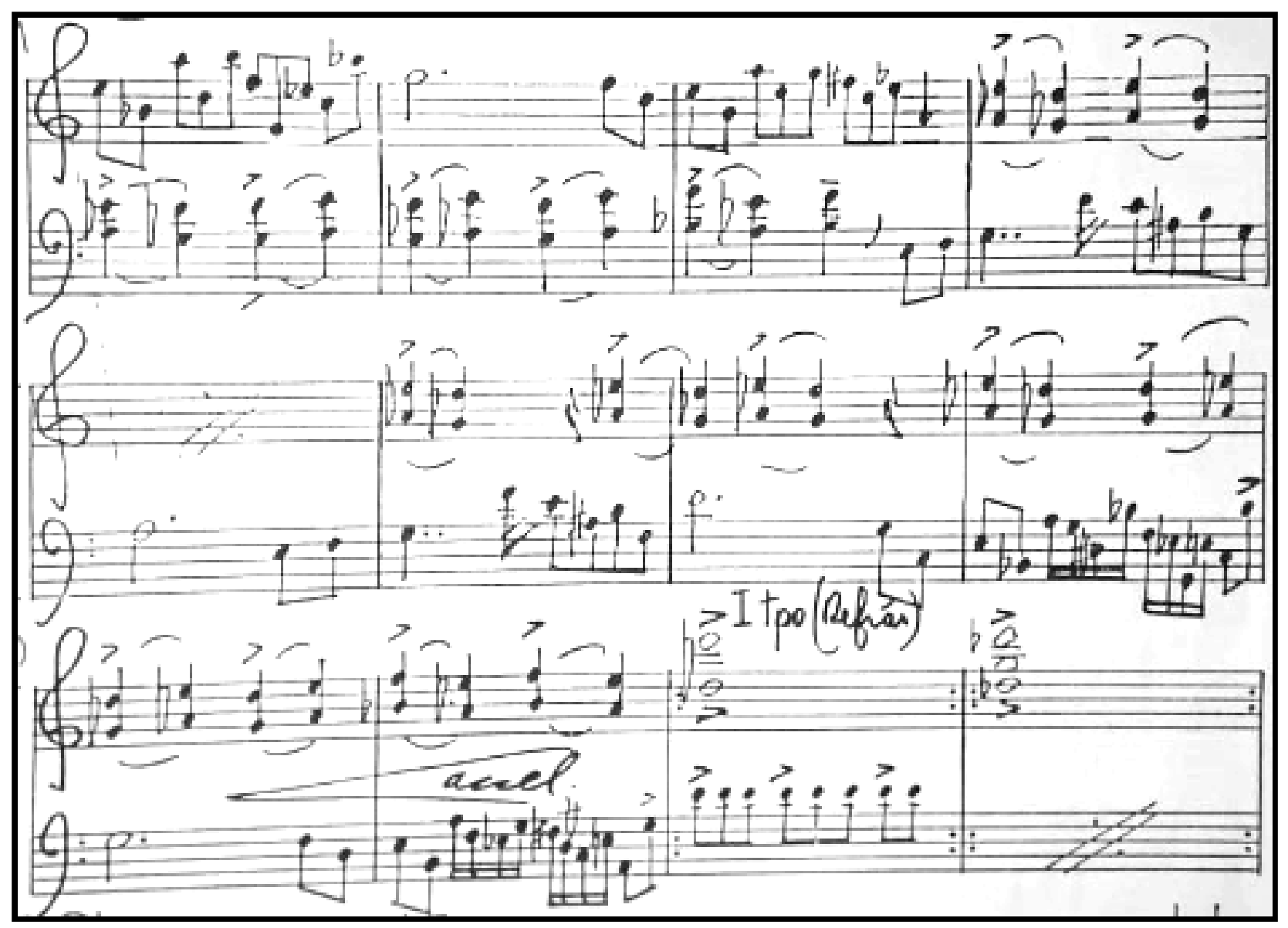

Example 12: Penalva's Piano Sonata no. 3 (1991). Manuscript's 3rd movement (agitato-rondó), mm. 81-92.

The final part of the sonata includes the beginning of the rondo refrain (ex. 13a, 13b, mm. 91-97), as well as the return of Episode II's themes (ex. 13b, 14, mm.

98-107). The piece ends with a coda set up by an energetic sequence of clusters in both hands, incorporating expanded technique and aleatoric rhythm, ${ }^{66}$ with dynamic markings indicating the initial rhythmic accentuation from the refrain (ex. 15, $\mathrm{mm}$. 109-111).

\footnotetext{
${ }^{66}$ Aleatoric (chance) music, from the Latin word alea, meaning "dice," is music in which some element of the composition is left to chance and/or some primary element of a composed work's realization is left to the determination of its performer(s).

https://en.wikipedia.org/wiki/Aleatoric_music\#: :text=Aleatoric\%20music\%20(also\%20aleatory\%20music. of\%20its\%20performer(s).
} 


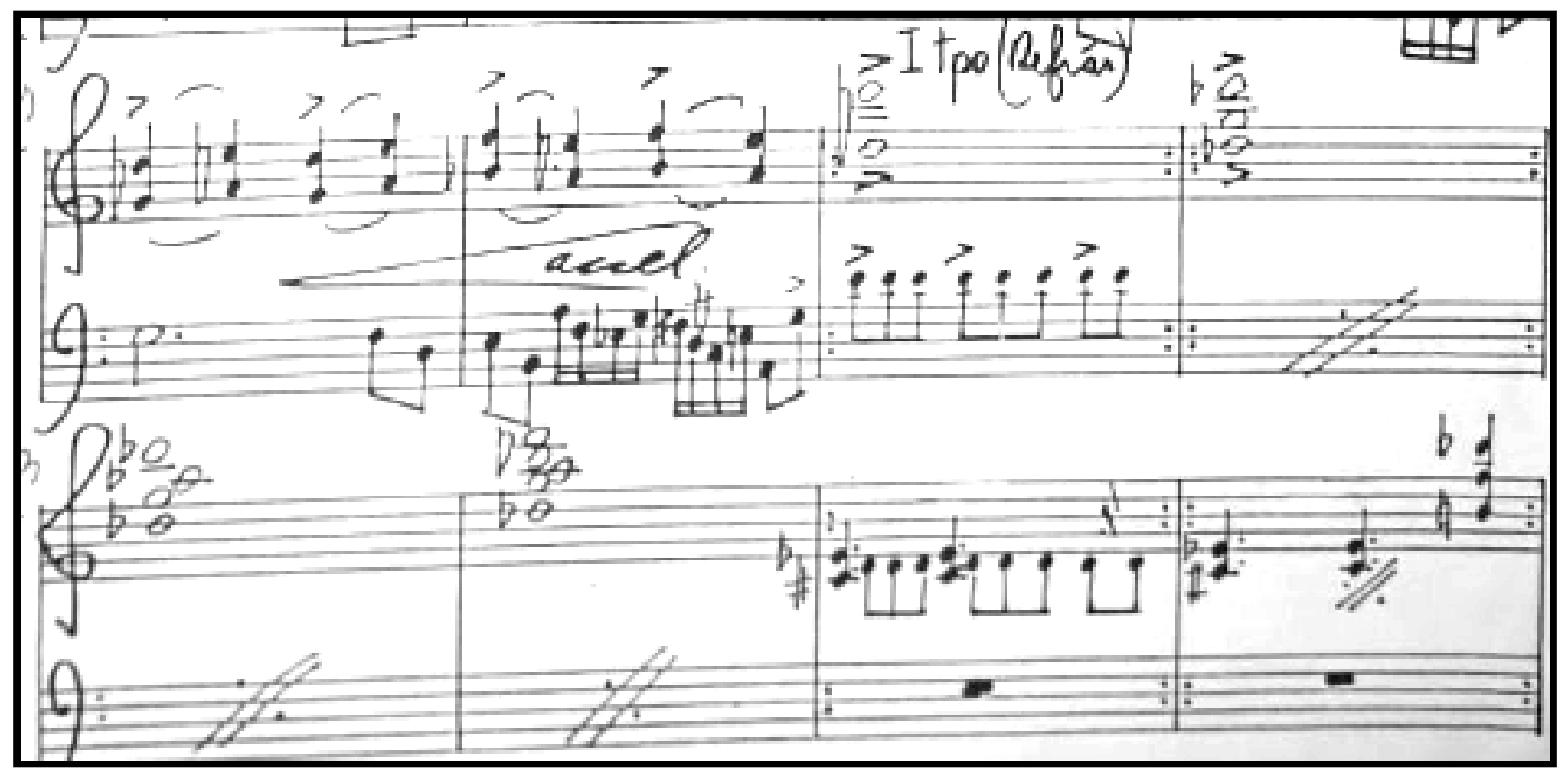

Example 13a: Penalva's Piano Sonata no. 3 (1991). Manuscript's 3rd movement (agitato-rondó), mm. 89-96.

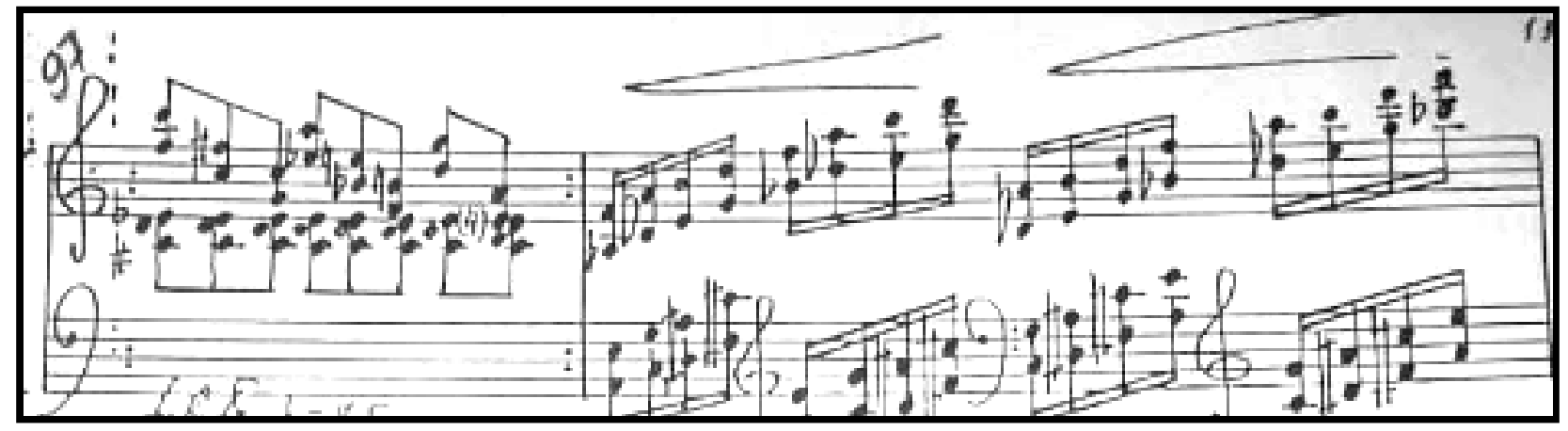

Example 13b: Penalva's Piano Sonata no. 3 (1991). Manuscript's 3rd movement (agitato-rondó), mm. 97-98. 


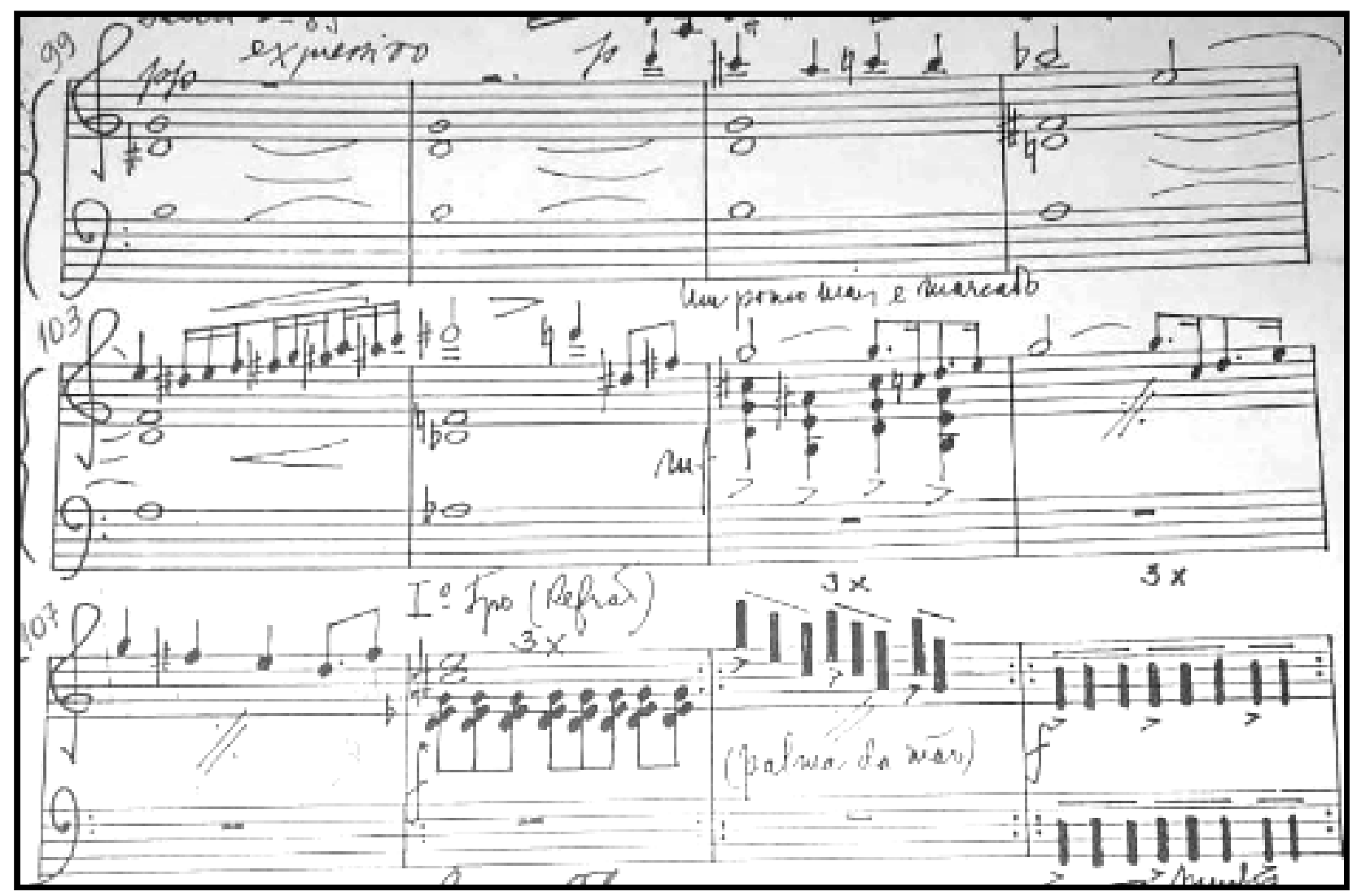

Example 14: Penalva's Piano Sonata no. 3 (1991). Manuscript's 3rd movement (agitato-rondó), mm. 99-110.

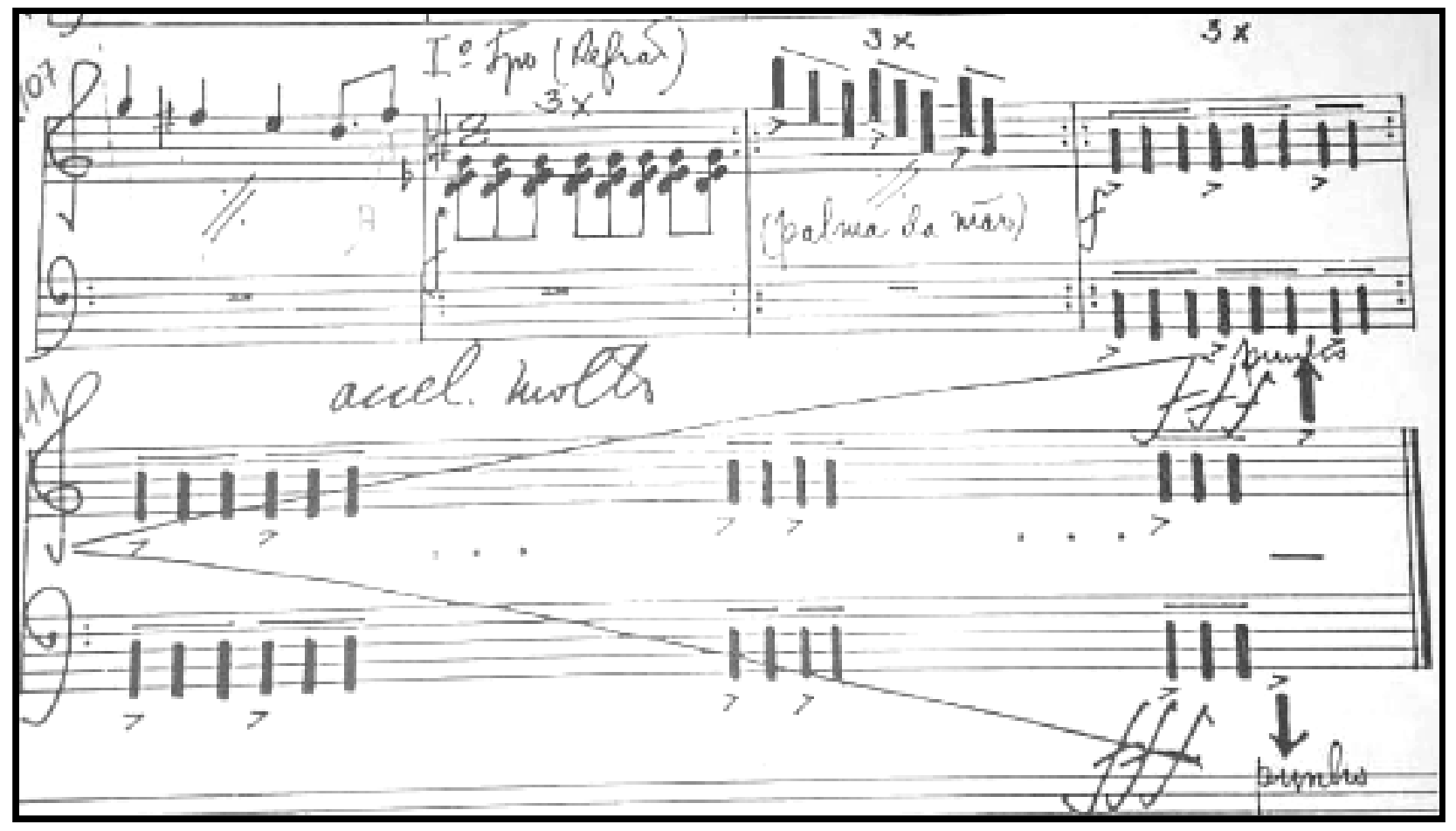

Example 15: Penalva's Piano Sonata no. 3 (1991). Manuscript's 3rd movement (agitato-rondó), mm. 107-111. 
As in his previous piano sonatas, Penalva also employs elements of a Brazilian popular genre, in this case the rhythmic lilt of baião in the third movement rondó. This folk element, along with the atonal language of the sonata, imparts an energetic and vibrant character to the final movement. The harsher sonorities, with dissonant harmonies and abrupt change of dynamics, contrast with moments of smoothness, as in the second movement's choral textures and melodic lines. Sonata no. 3 displays intricate motivic work and it is by far the most musically and technically complex among Penalva's three sonatas. 


\section{Conclusion}

This research project presents José de Almeida Penalva's biography and an account of his musical output, evaluating his importance as a musician, academic and priest. His trajectory proved to be broad and profound in all his fields of activity, revealing his great contribution to Brazilian music, to the piano, and to the educational and religious segment of the Claretians in Brazil, to which he belonged. His work as a teacher and cultural advocate is evident in the numerous festivals that he promoted, and in his essential academic work with universities. The set of his musical activities, and his production as a whole, also corroborate the training and experience of a human being engaged in his time. His deep knowledge of folklore; of the most varied musical forms; of world languages and genres; of classical, popular and liturgical music; and of religious thought, all provided the source material which he understood, manipulated and utilized in varied ways in his musical and liturgical production.

Further, this paper provides an overview of Penalva's musical output, together with a specific listing of his piano works, so that the reader may have a general understanding of his production for the instrument. Additionally, some of his works that have not been mentioned in previous writing, such as "O cuco" and an unfinished set of bagatelles; the latter, recently located at the Claretian Museum in Curitiba, PR, are incorporated.

I have provided an extensive analysis of Penalva's three sonatas for piano in order to augment and corroborate previous analysis of these works. Here, I have taken 
the opportunity to present my personal opinion on the language of Penalva's music, and on the large and small-scale structural forms he employed. We see several common aspects among the sonatas:

1. All three begin with introductory material and employ traditional sonata form in their first movements or sections;

2. The centrality of $D$ minor (whether in mode or serial row) appears in the first movements of all three sonatas and in the second movement of Sonata no. 2;

3. The Brazilian folk element is always present somehow; and

4. The pianistic writing reveals extensive use of such elements as quartal chords, wavy melodic lines, clusters, and contrapuntal textures.

These sonatas are exemplary pieces in Penalva's output. They demonstrate his use of eclectic forms and language, encompassing traditional and modern musical forms along with elements of Brazilian folklore. The sonatas also reveal piano writing by a composer deeply familiar with vocal music and counterpoint. On the whole, Penalva's sonatas provide an overview of his musical trajectory. According to his own words, his reason for writing the sonatas was really "... the moment when [he wrote them]," because each of them represents the inauguration of a new stylistic phase of his compositional career.

I believe strongly that Penalva's music, including the three piano sonatas, deserves to be enjoyed by a wider audience and I look forward to doing my part to help that happen. 
Appendix 1a - Penalva Sonata no. 1 (Manuscript, 1970)

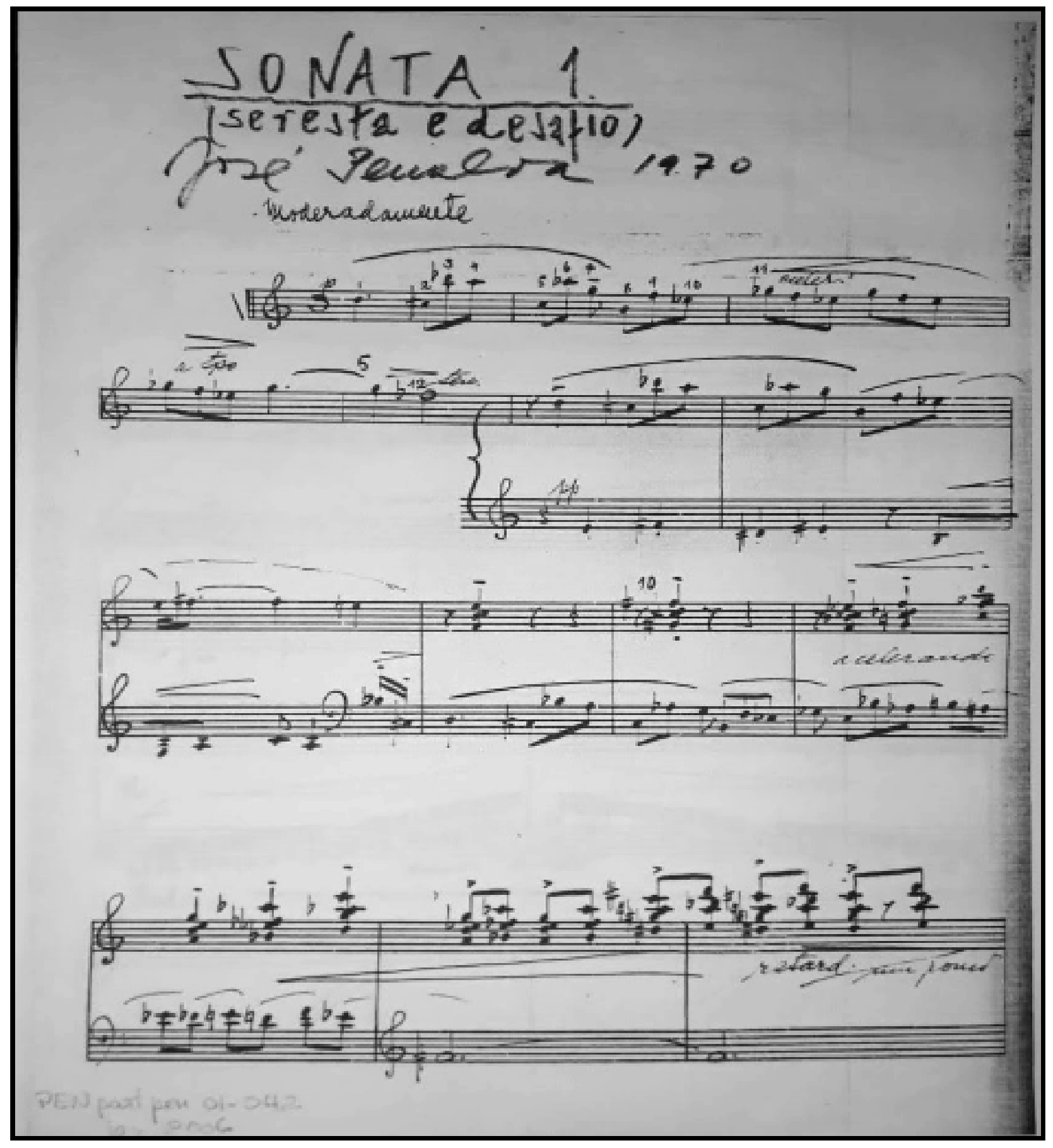




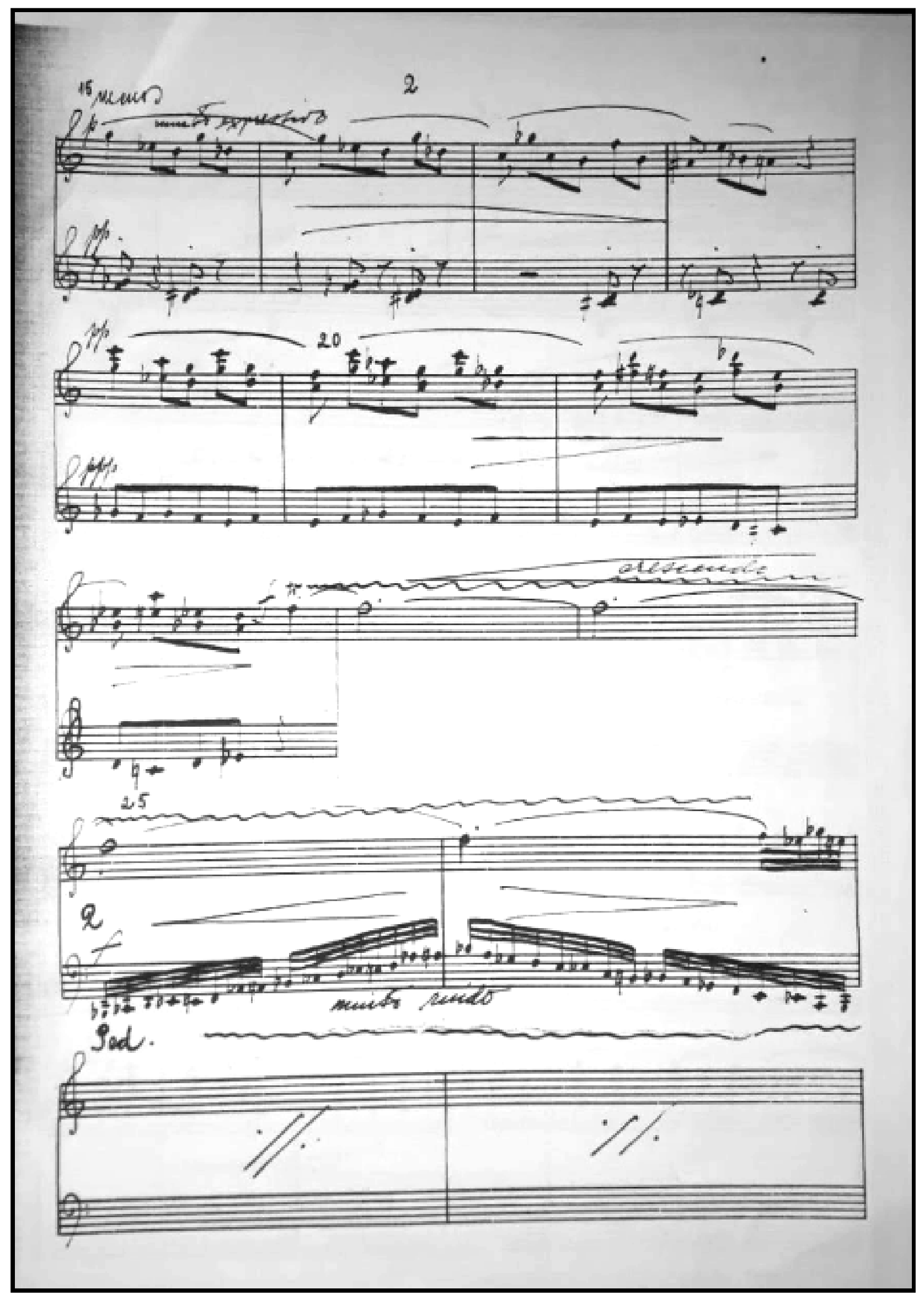




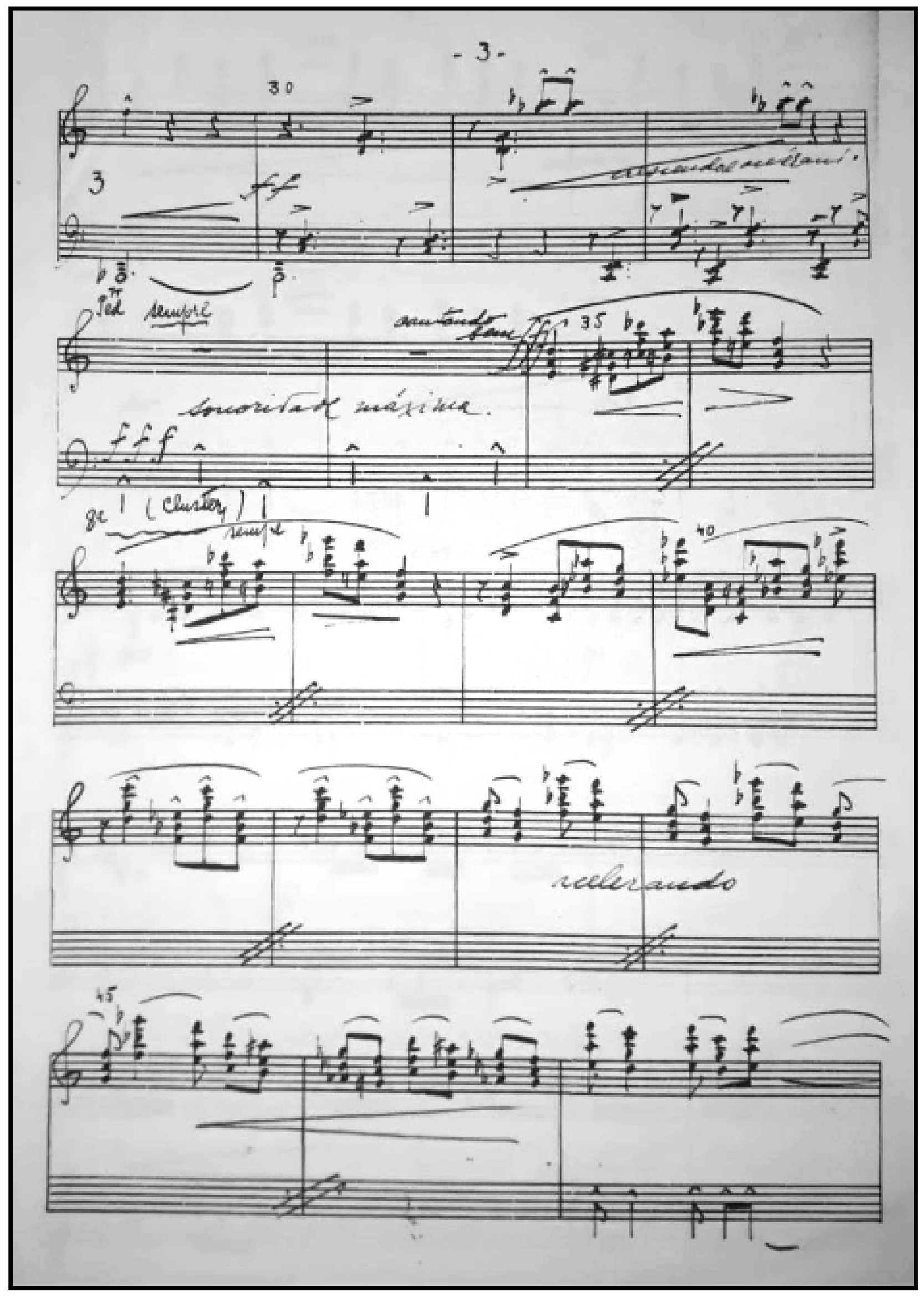




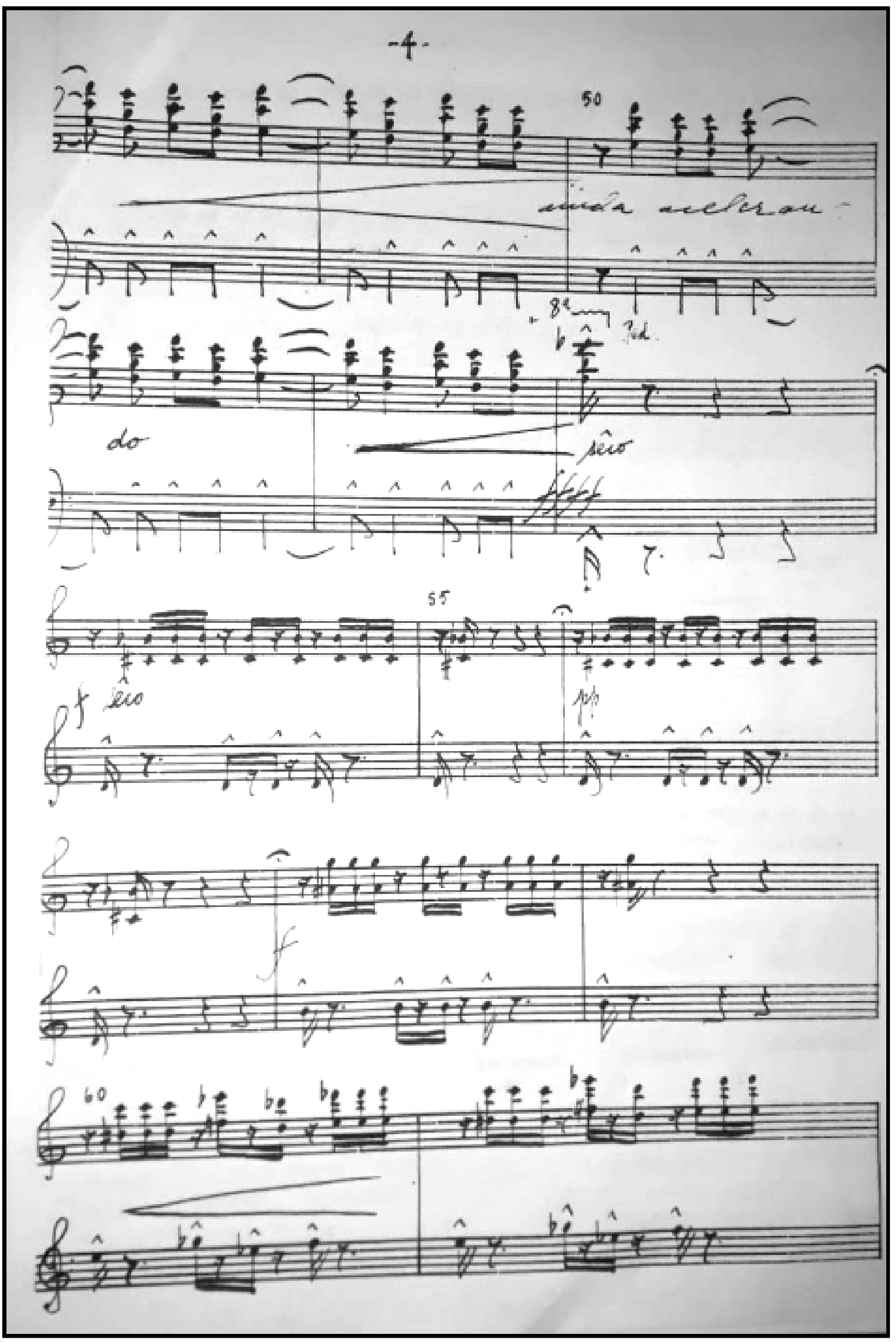



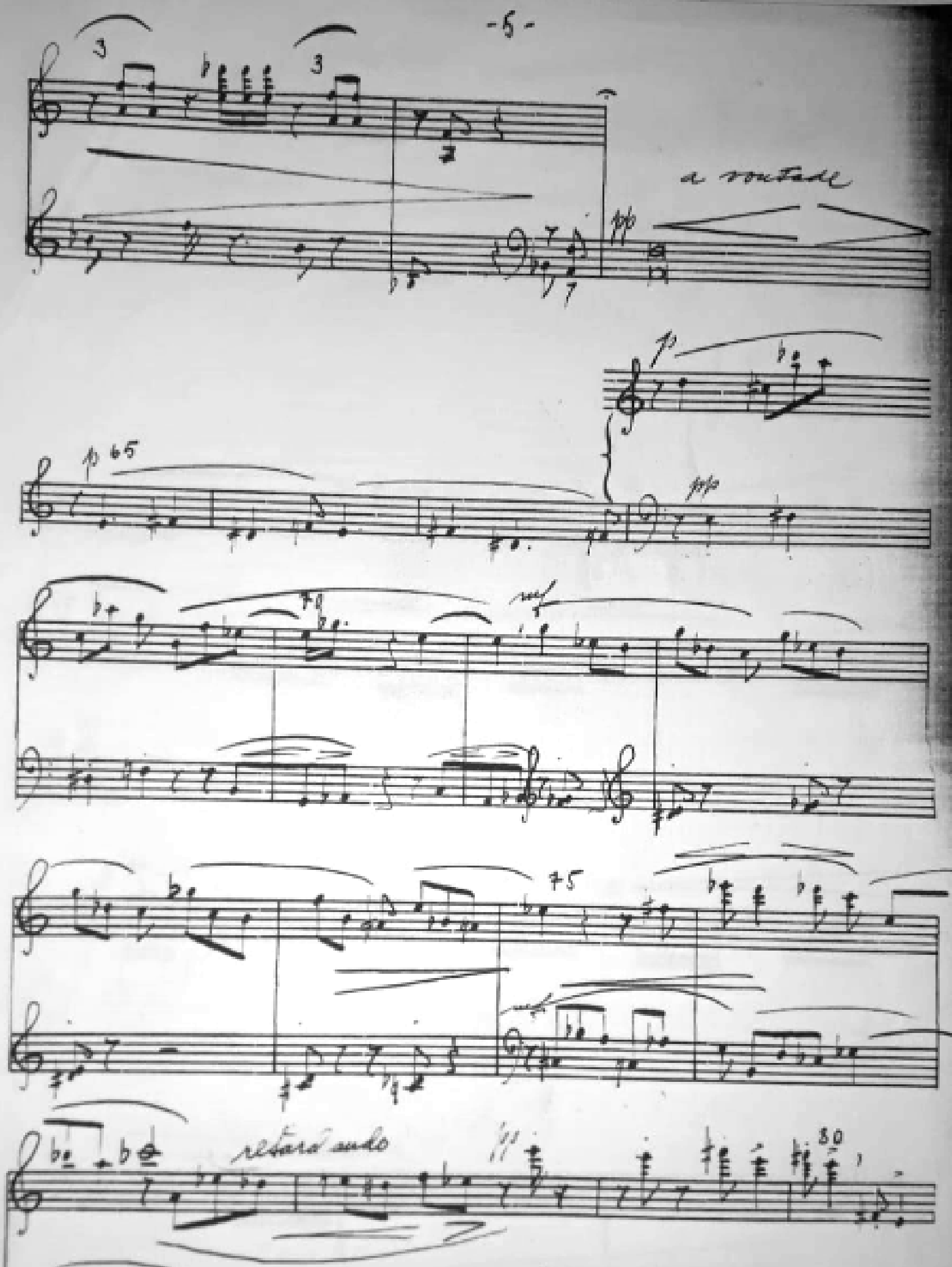


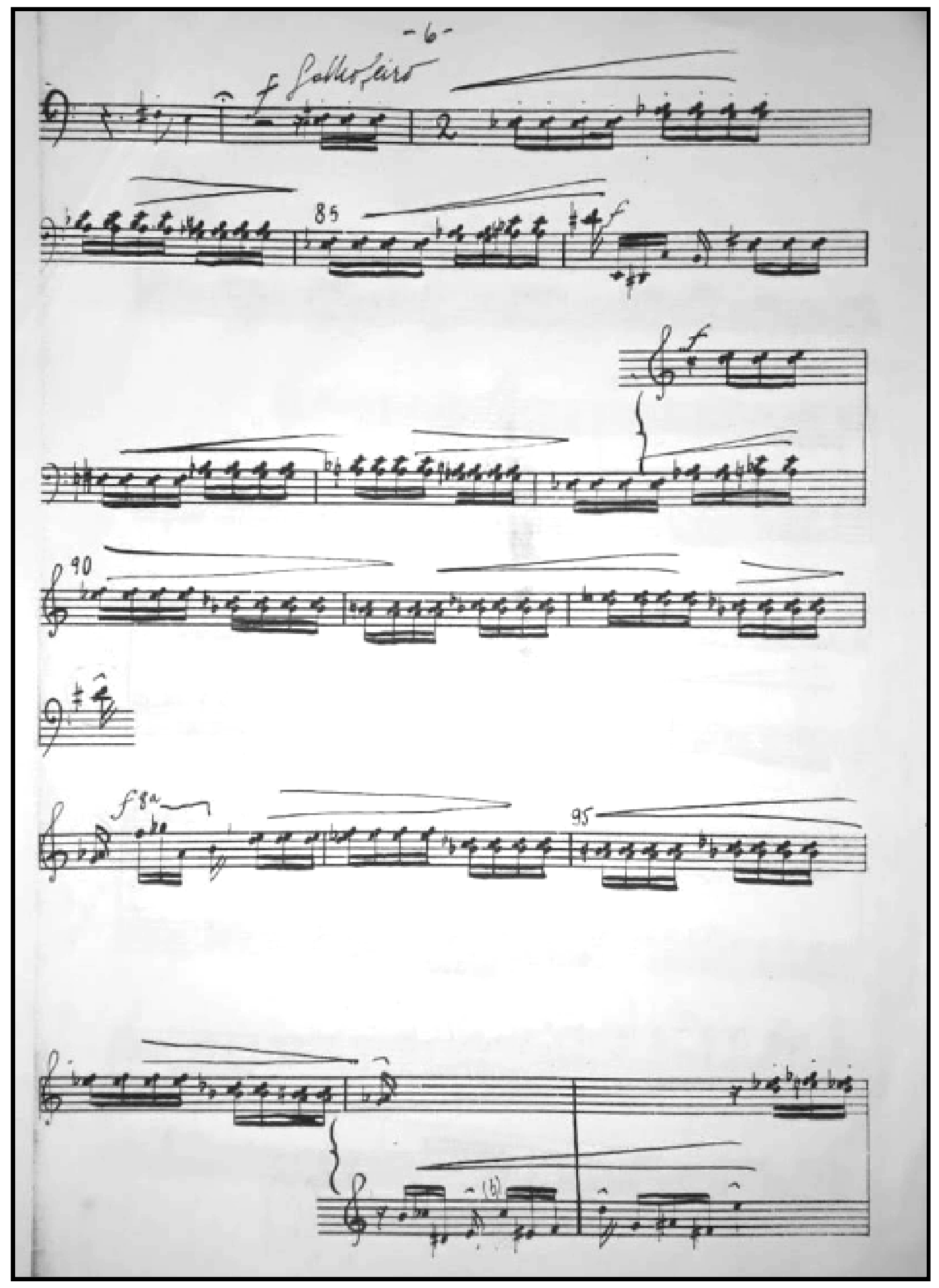


Pres

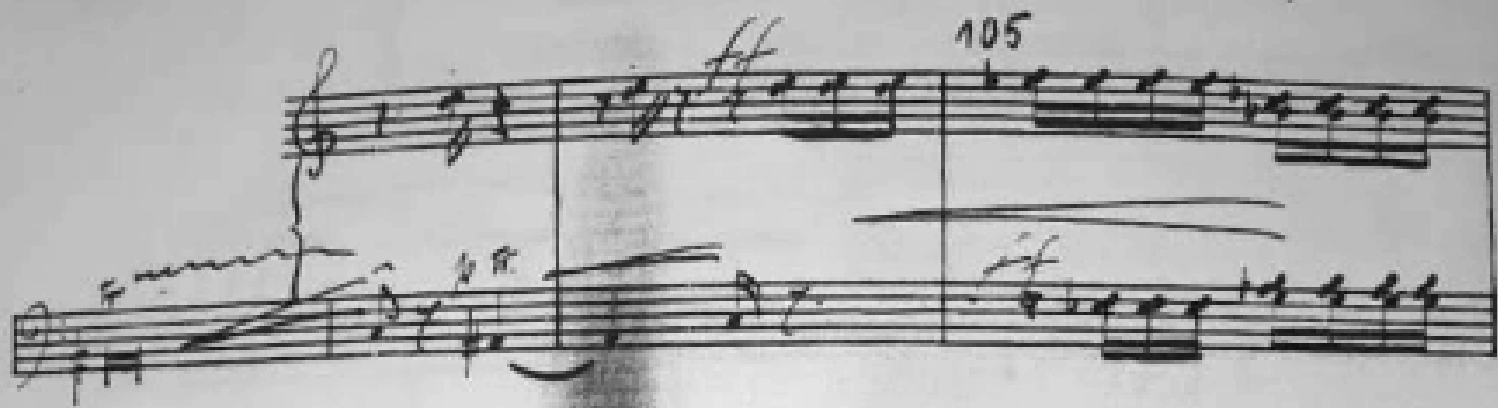

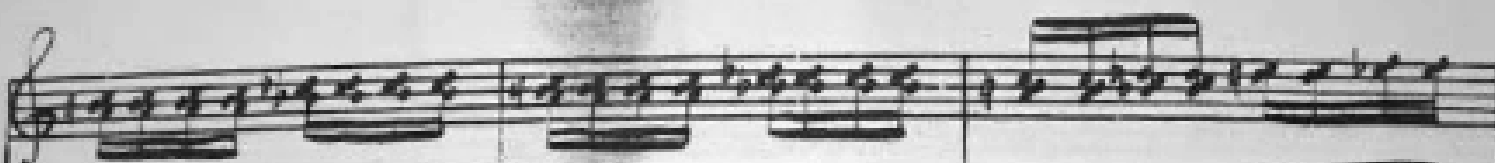
$\gamma=-1$ -

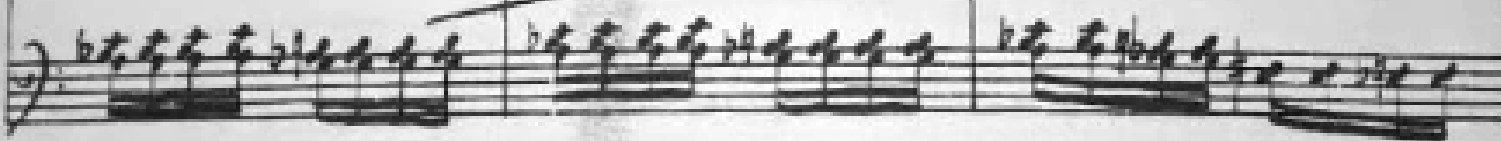

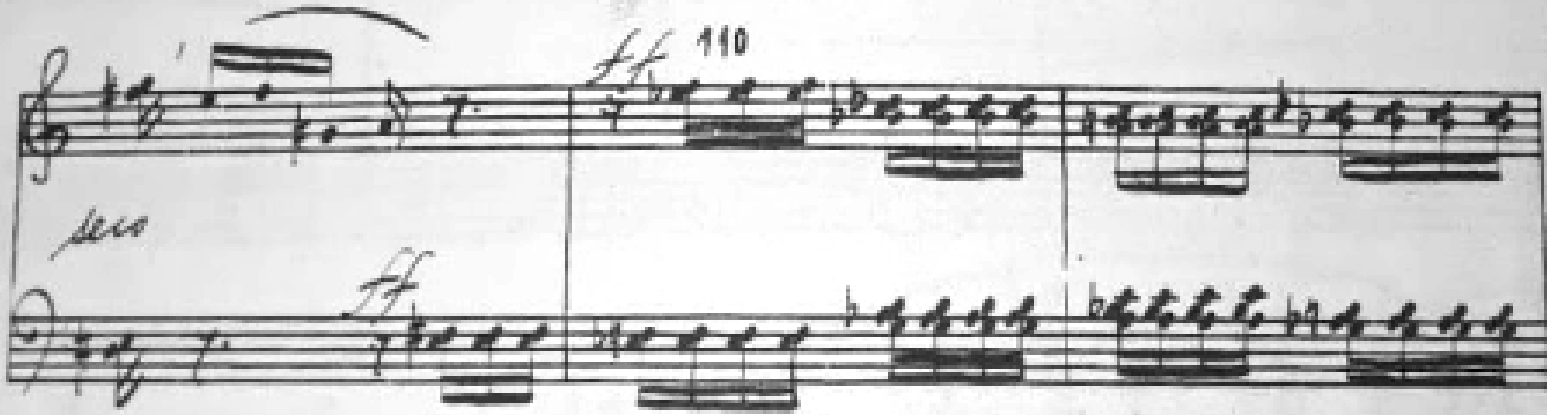

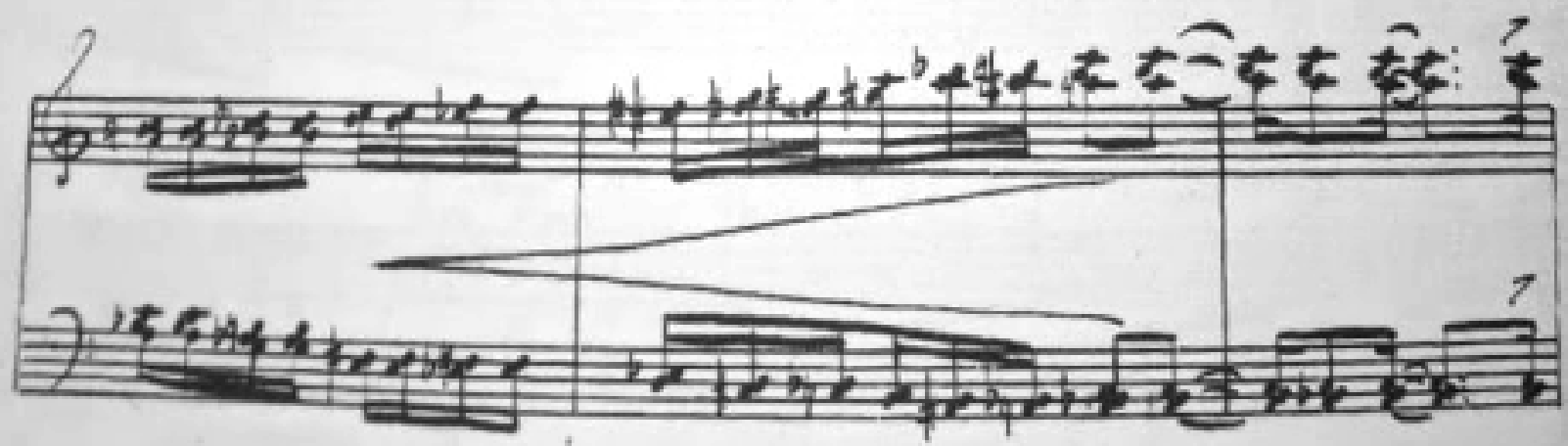




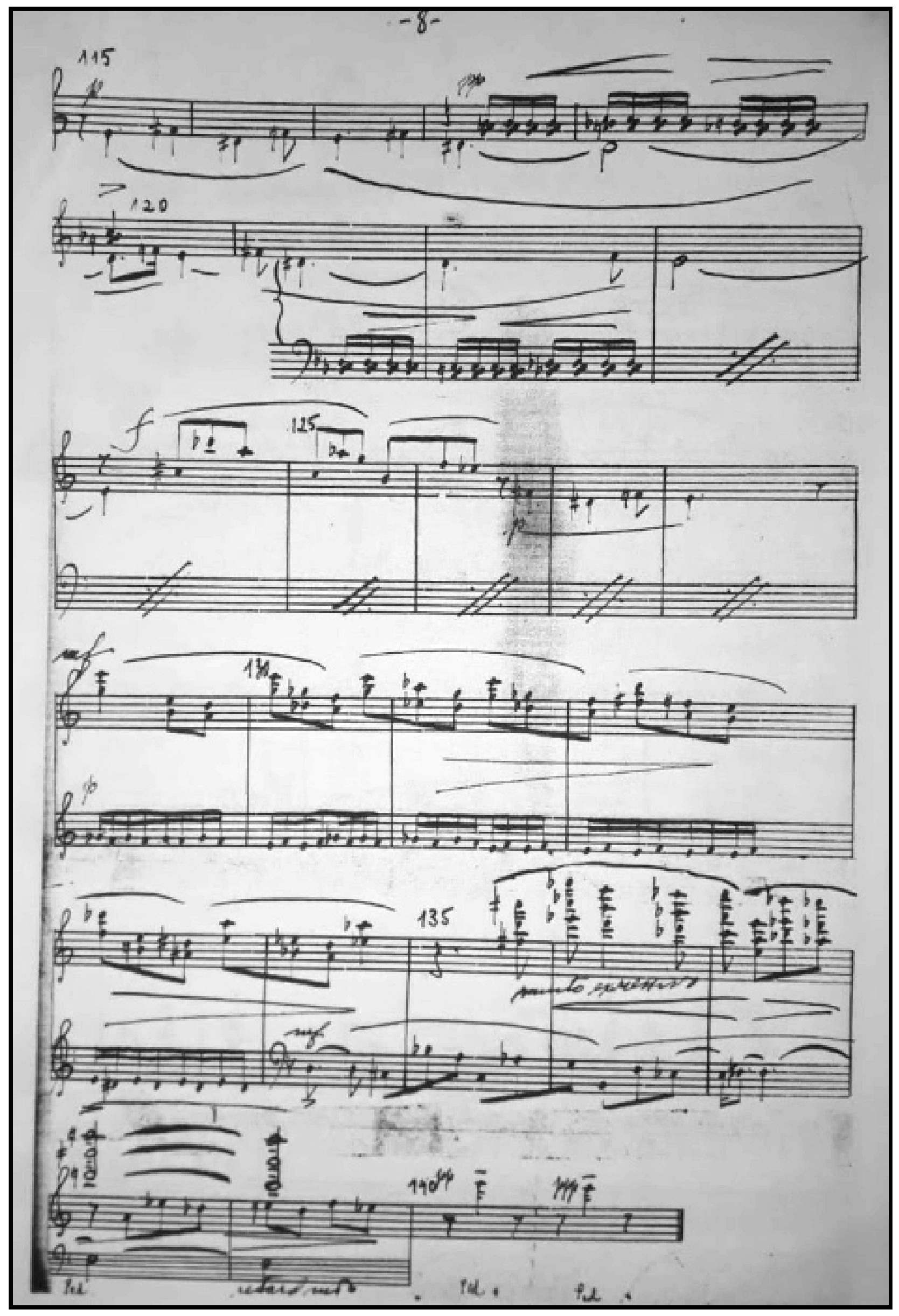


Appendix 2 - Penalva Sonata no. 2 (Manuscript, 1960)

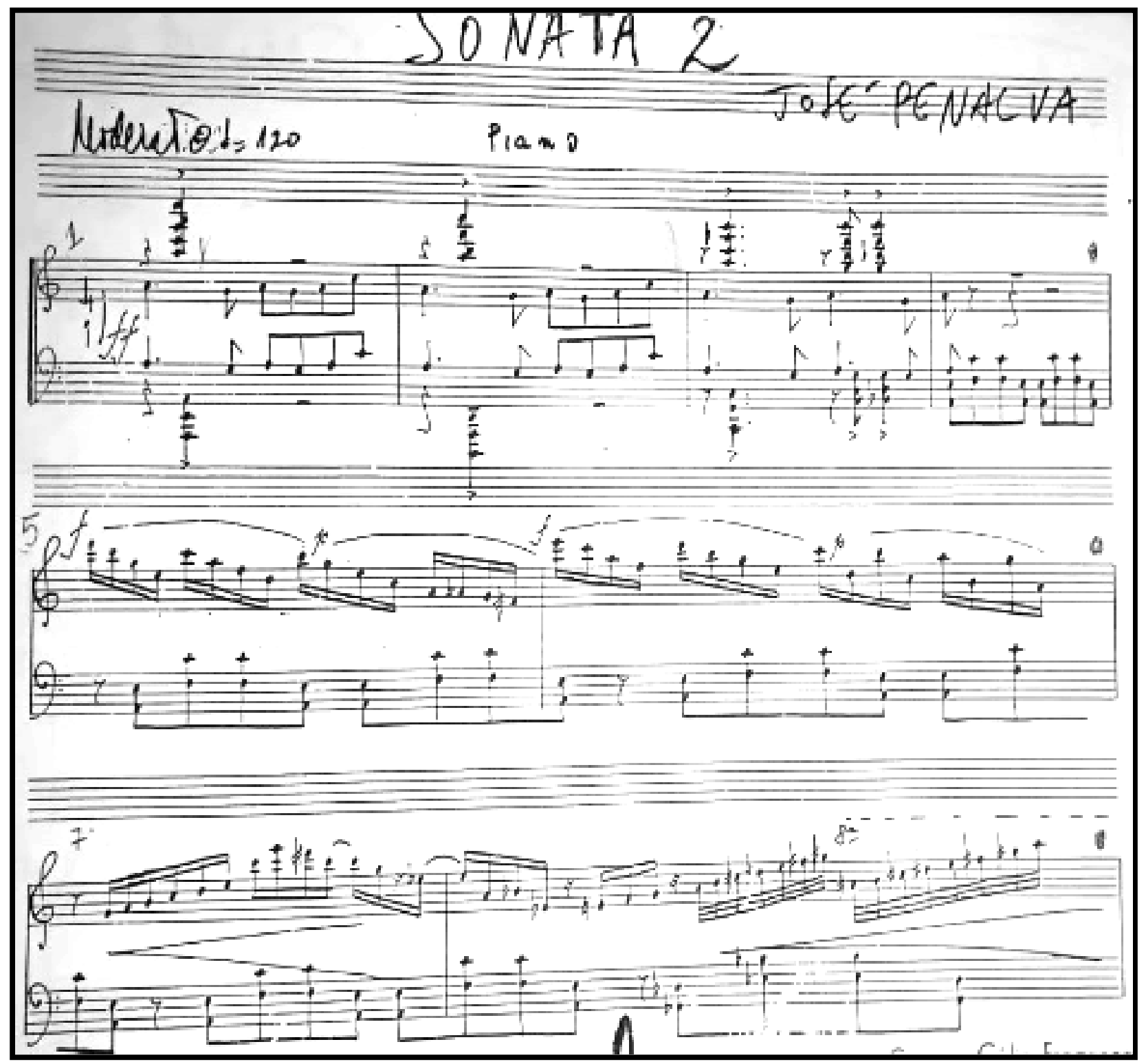




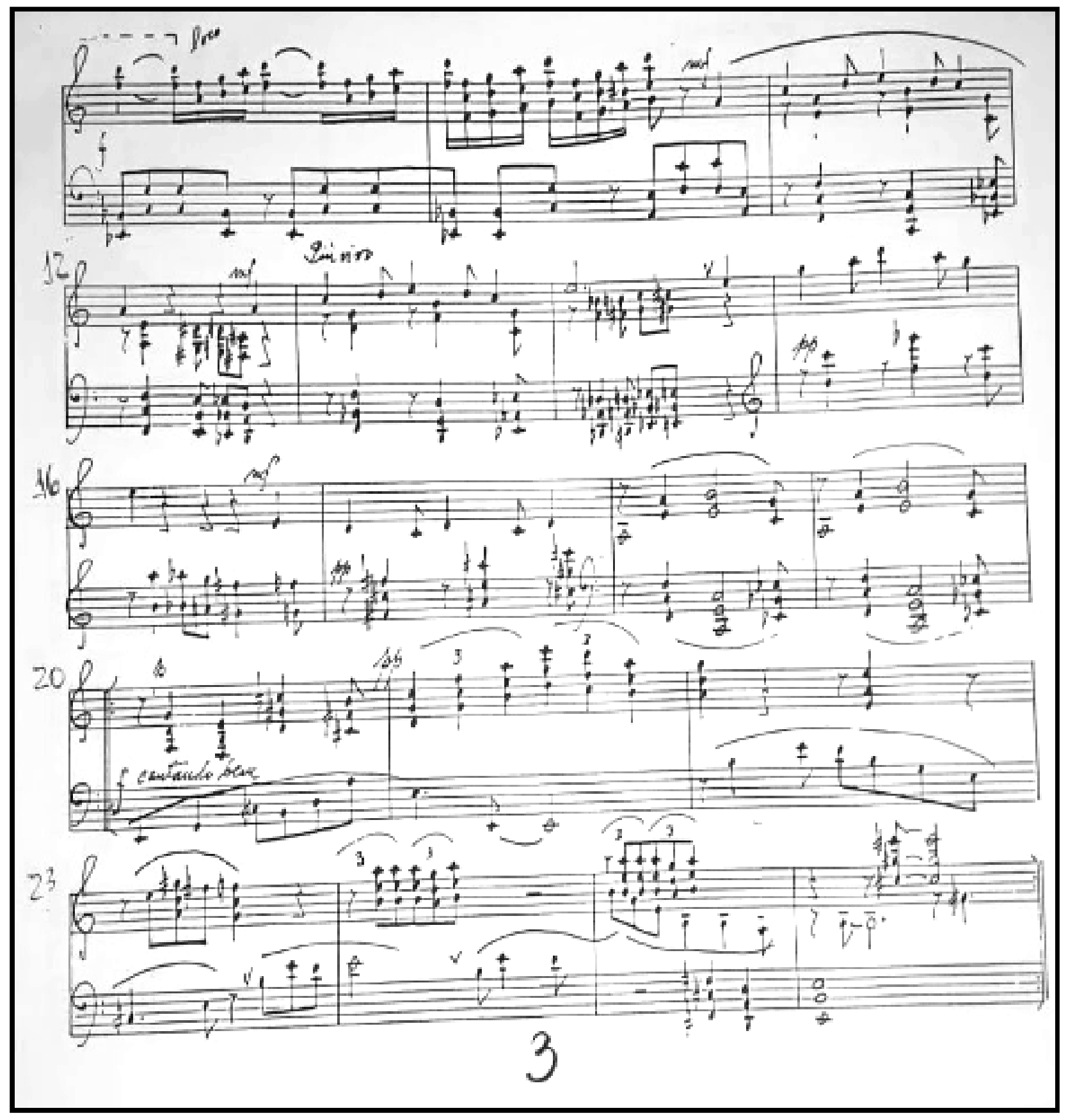




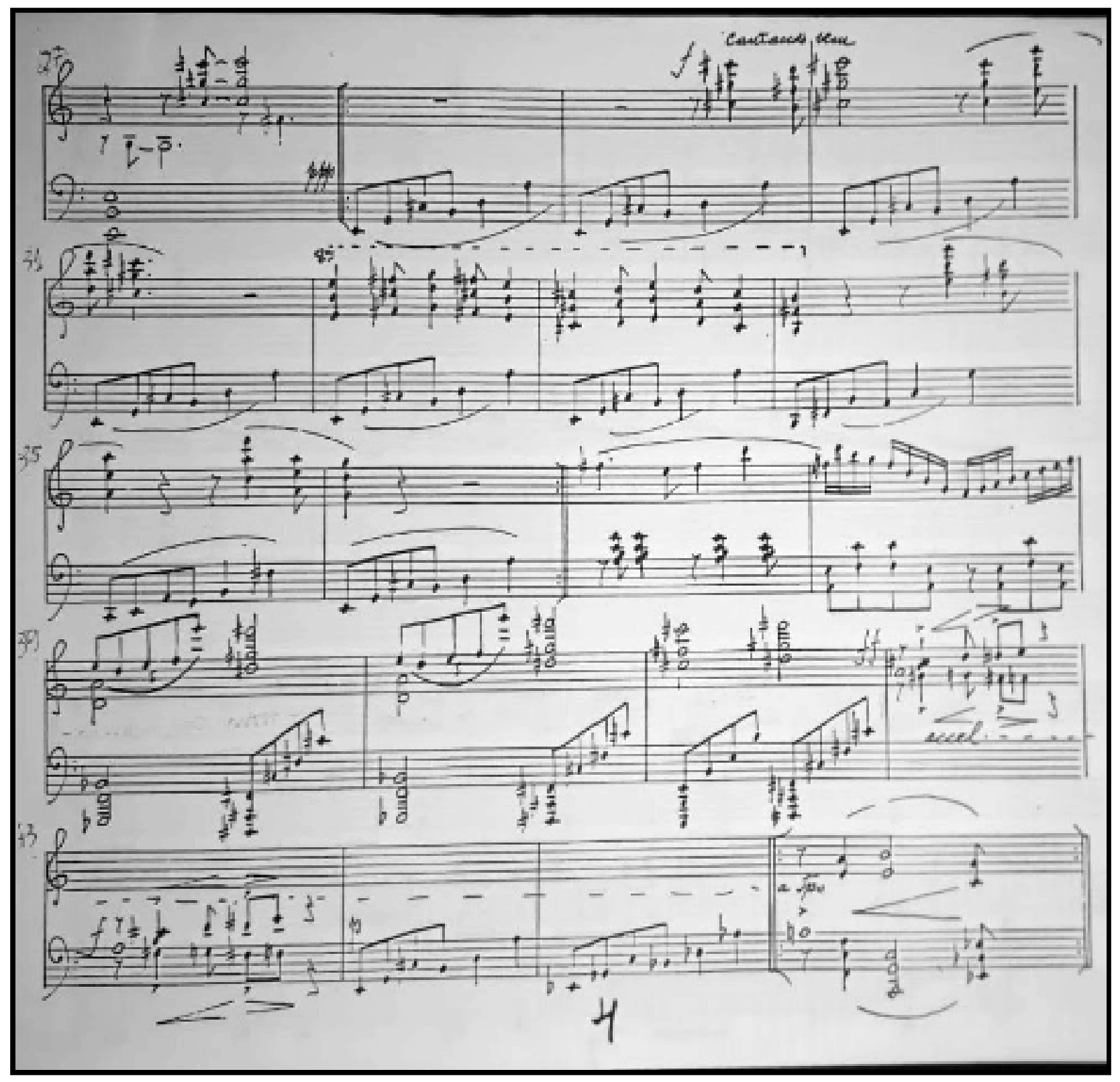




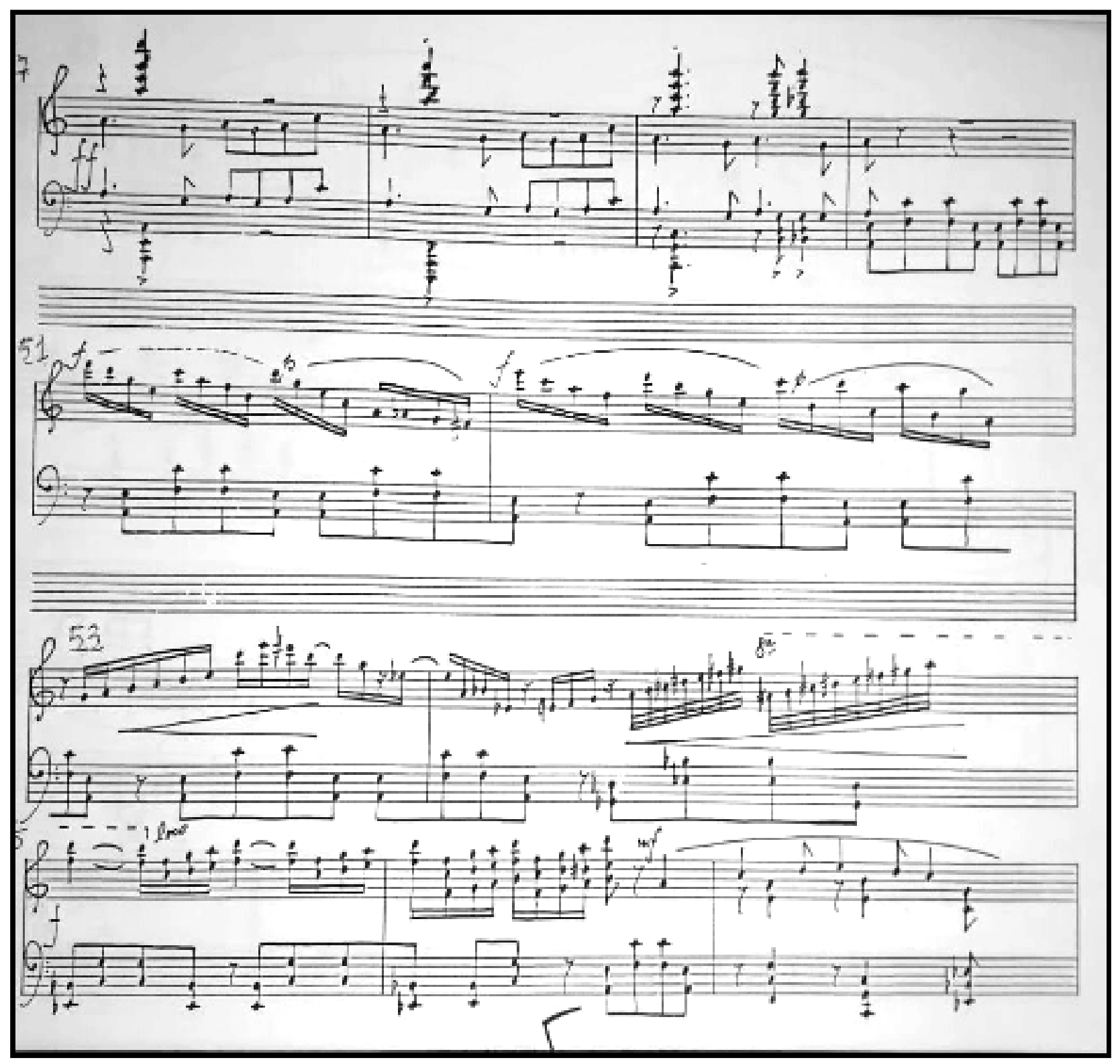




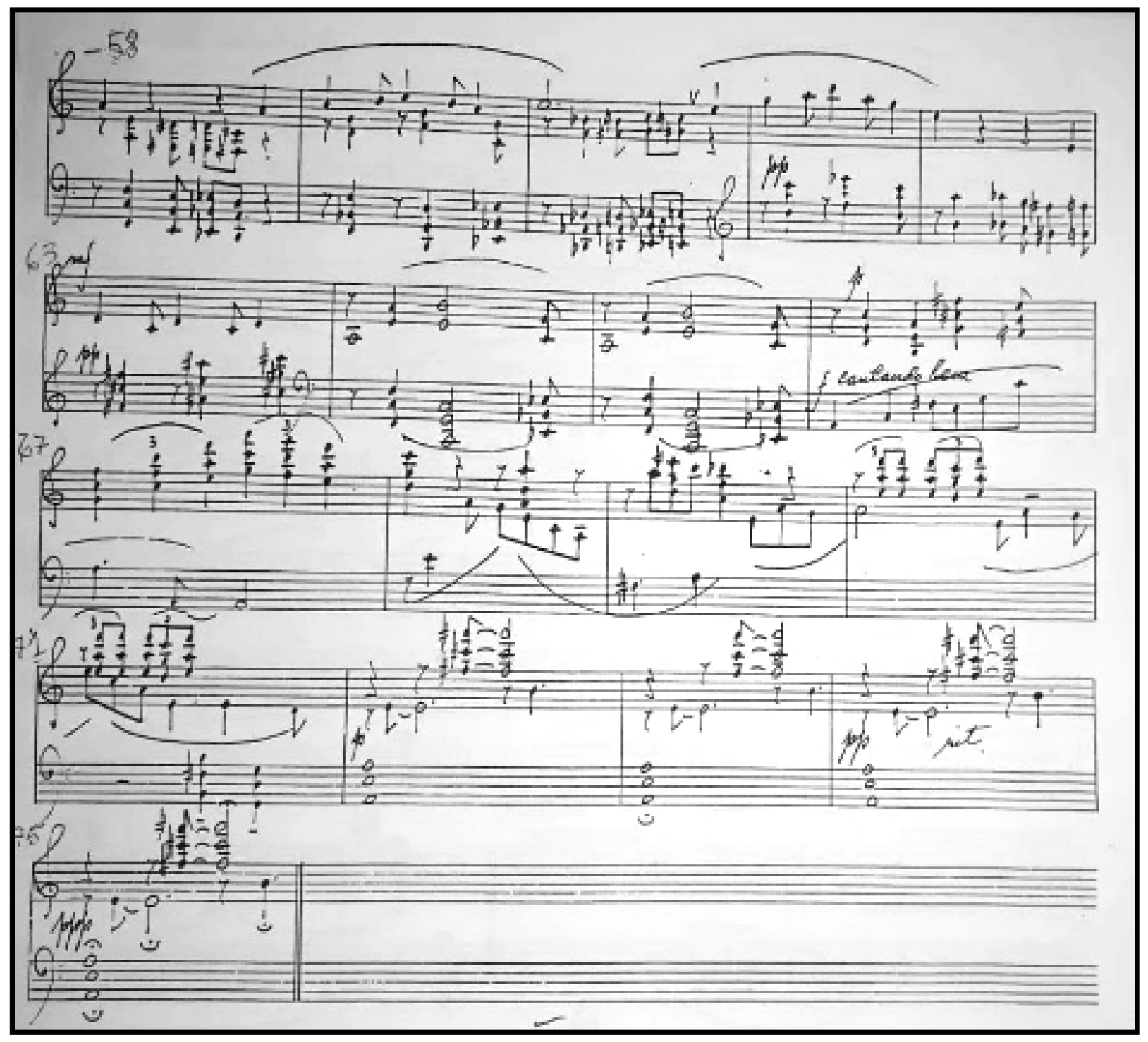




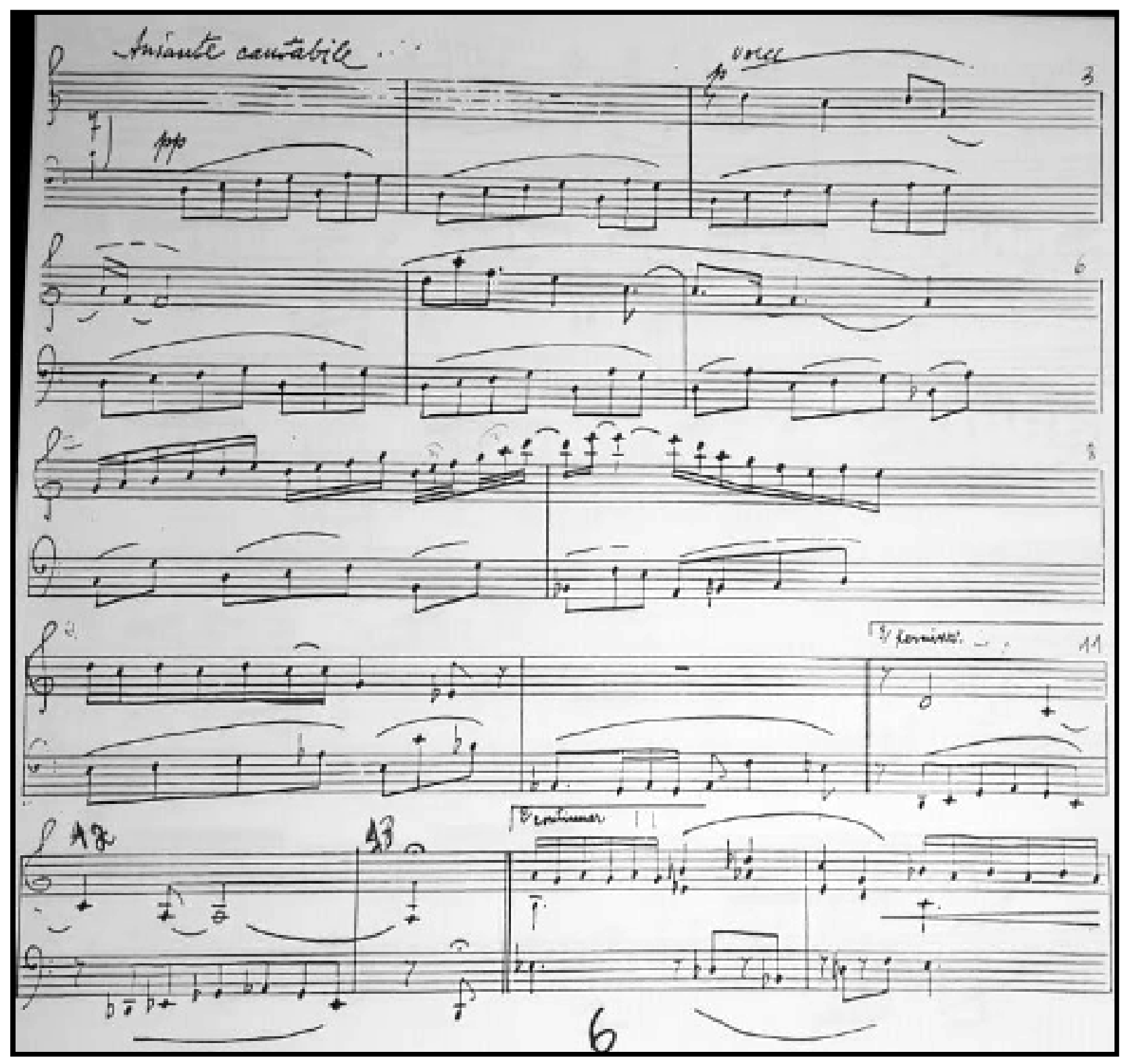




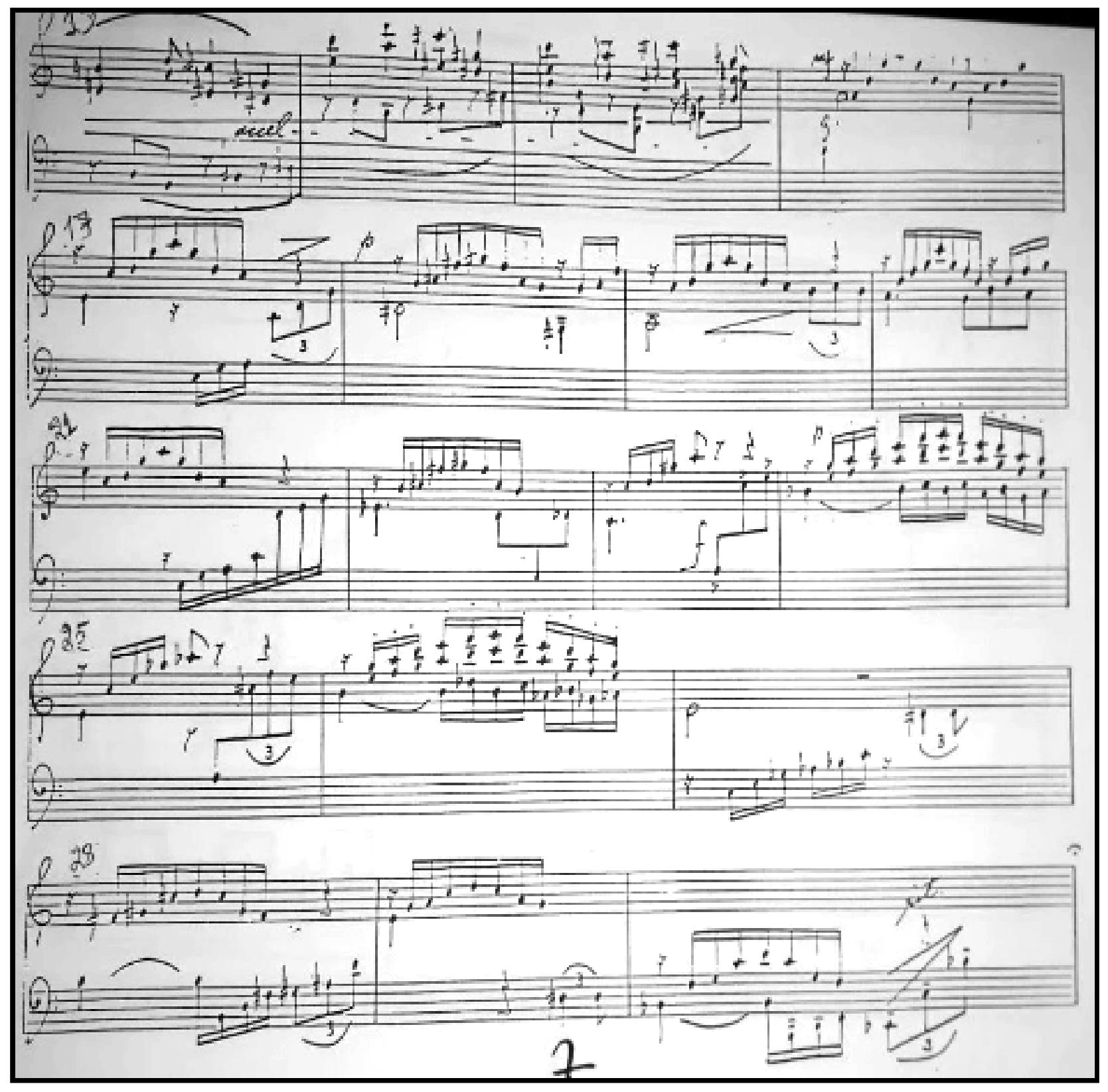




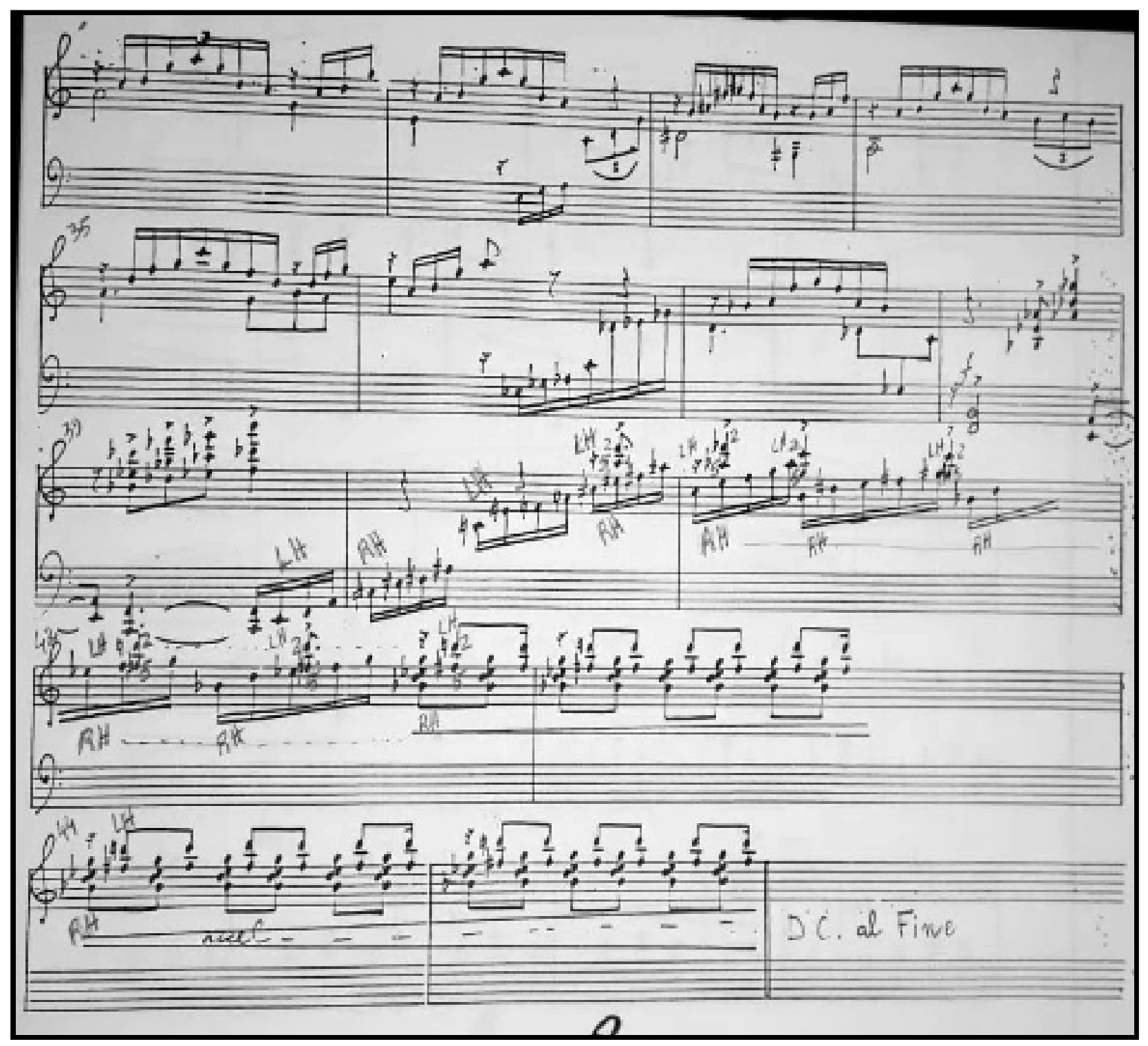




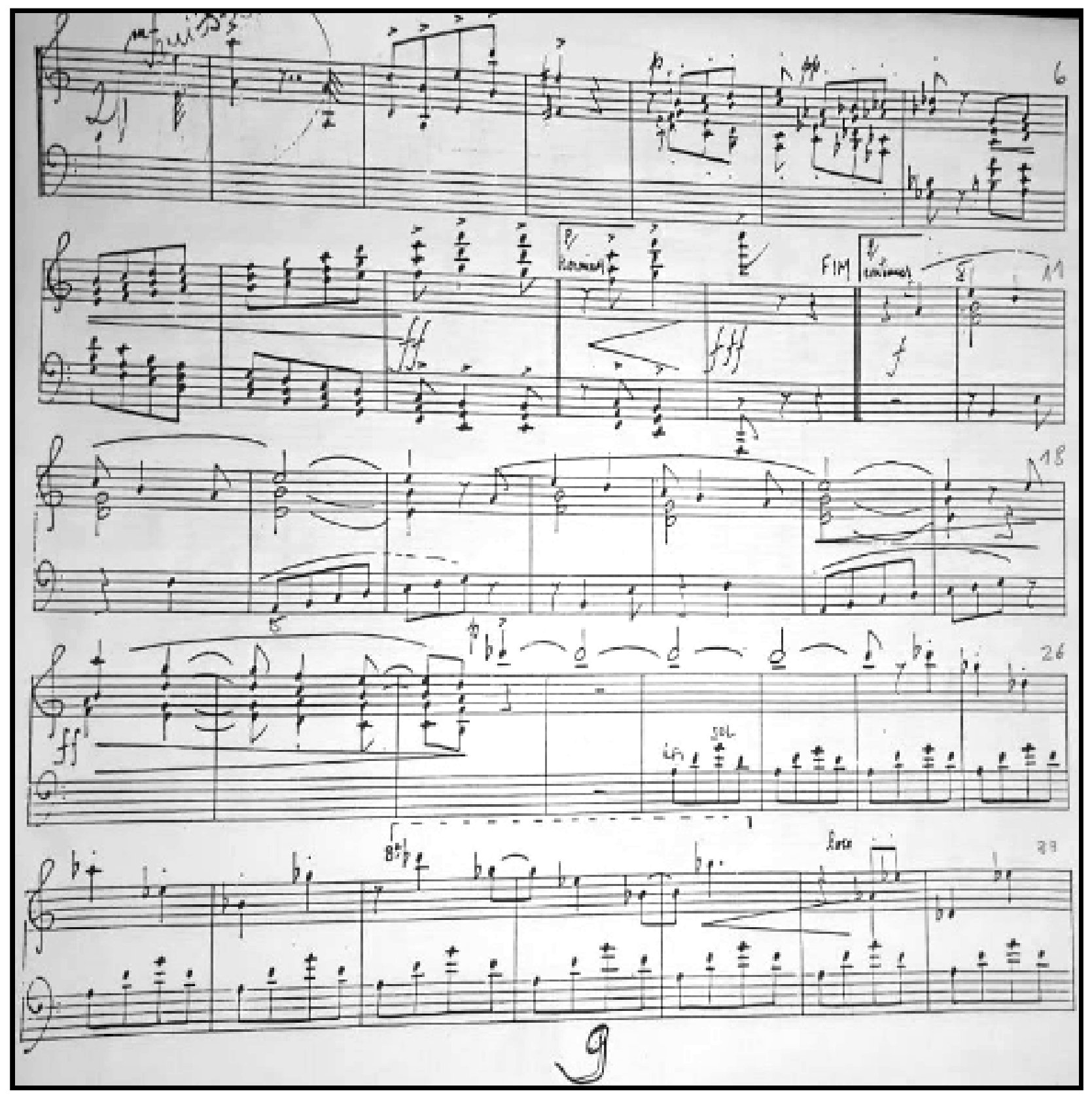




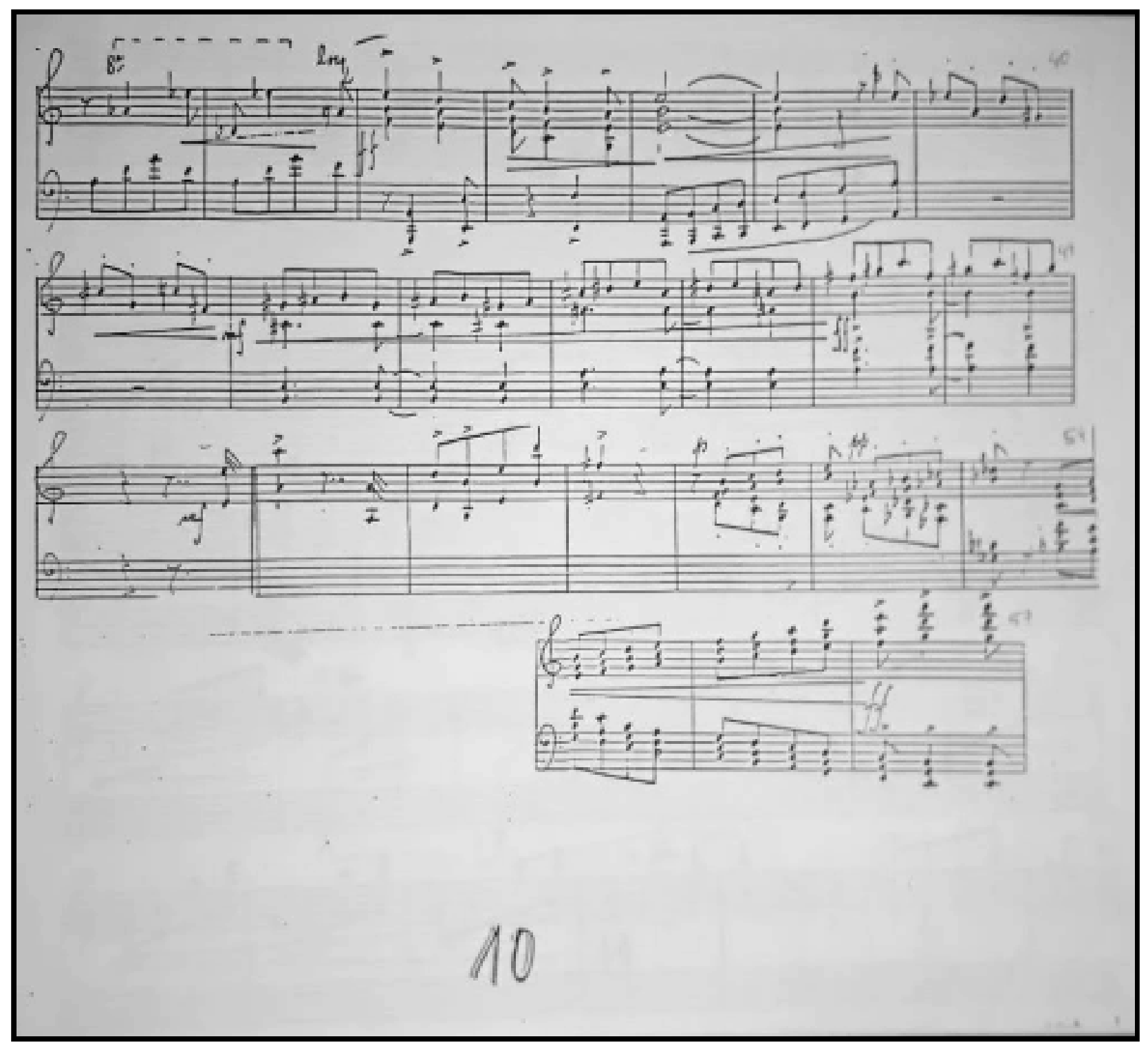




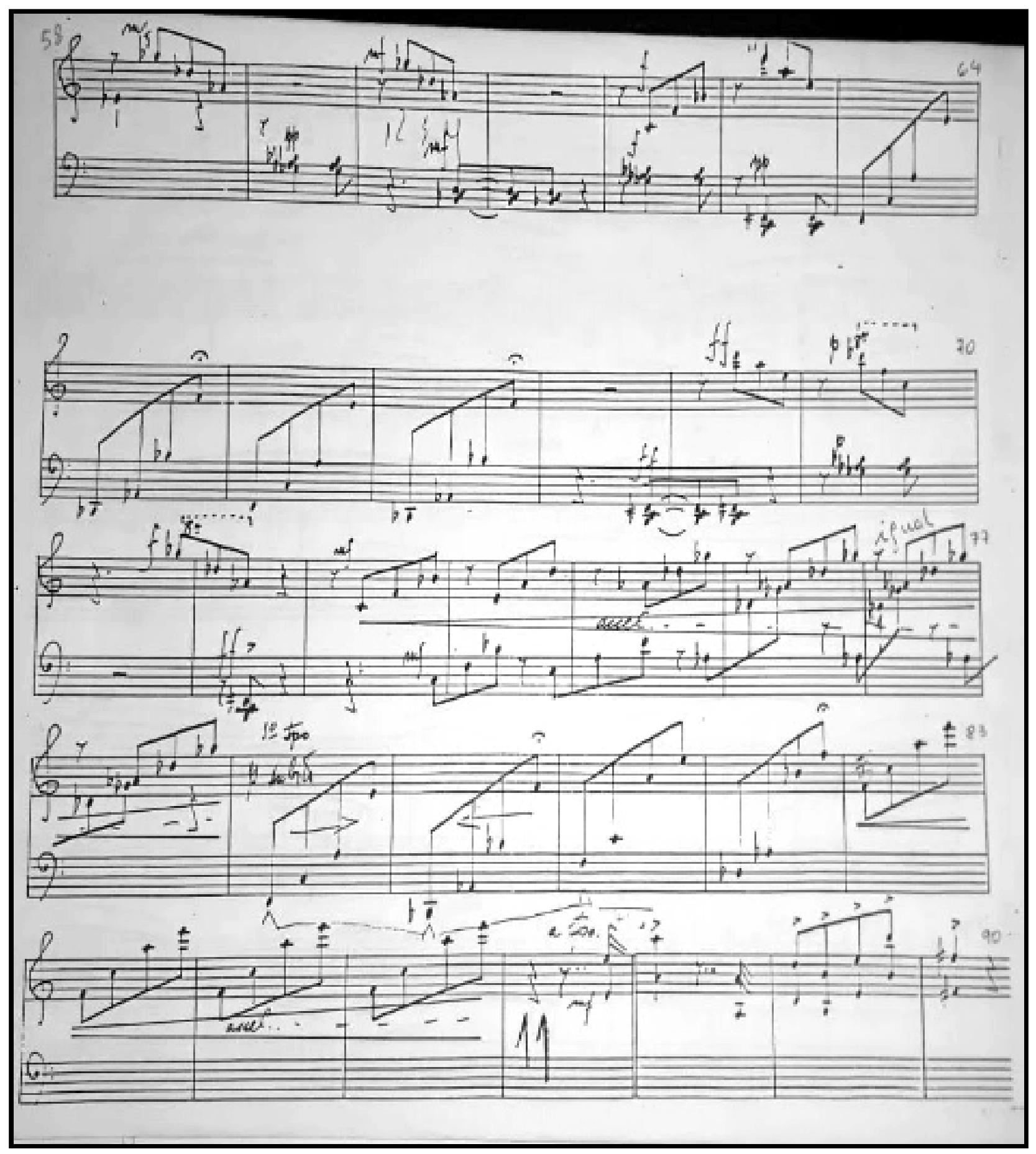




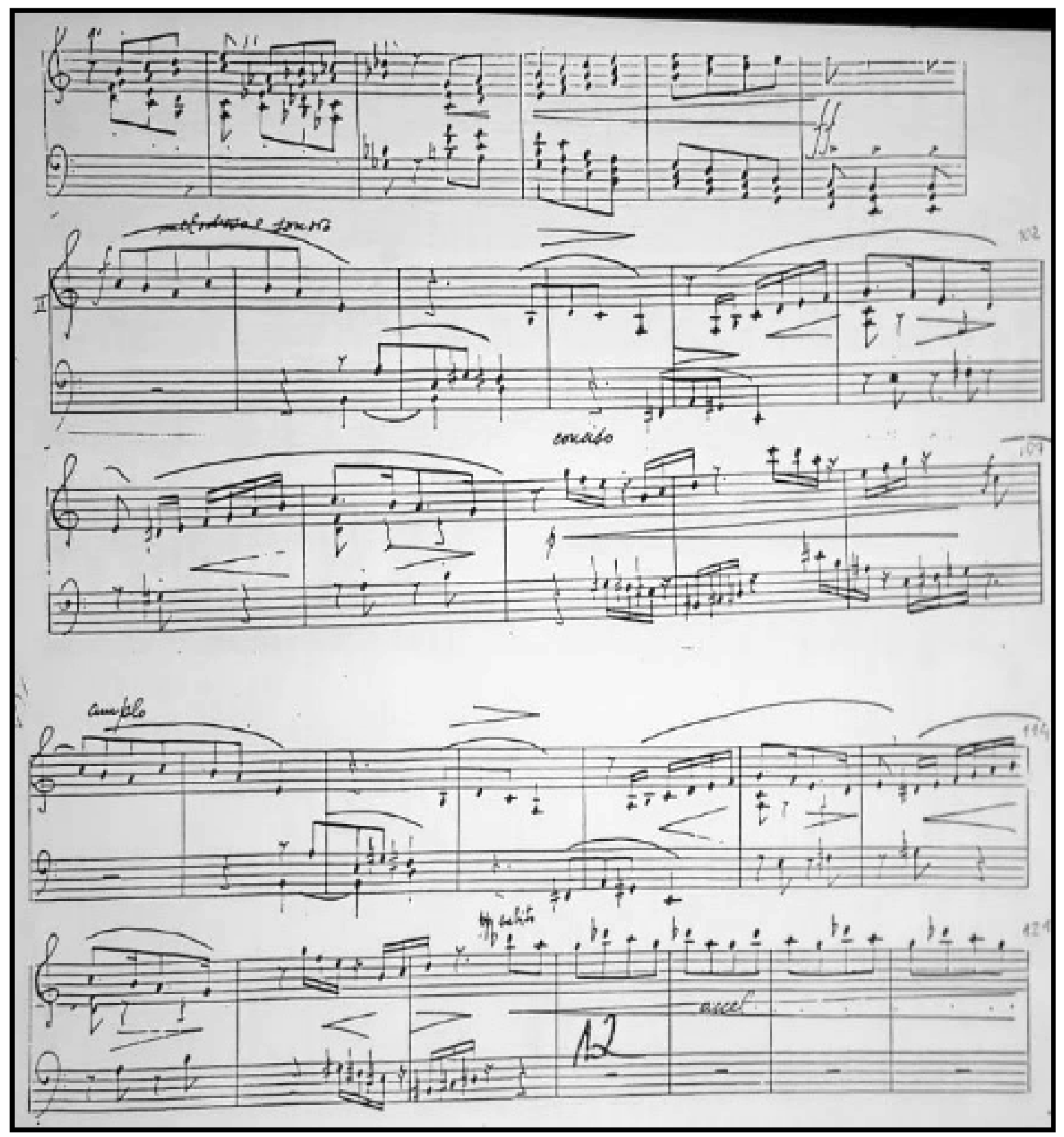




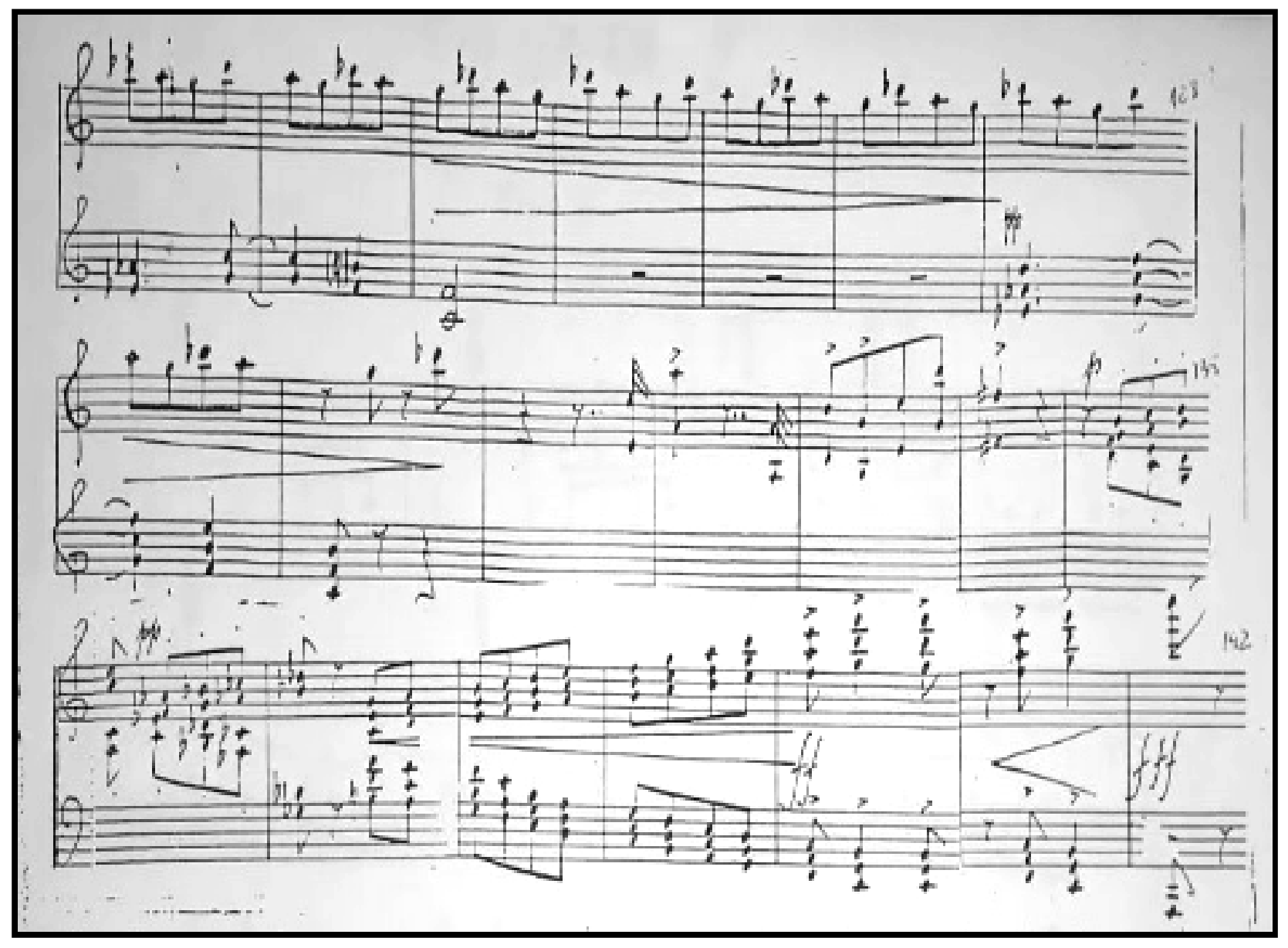


Appendix 3 - Penalva Sonata no. 3 (Manuscript, 1991)

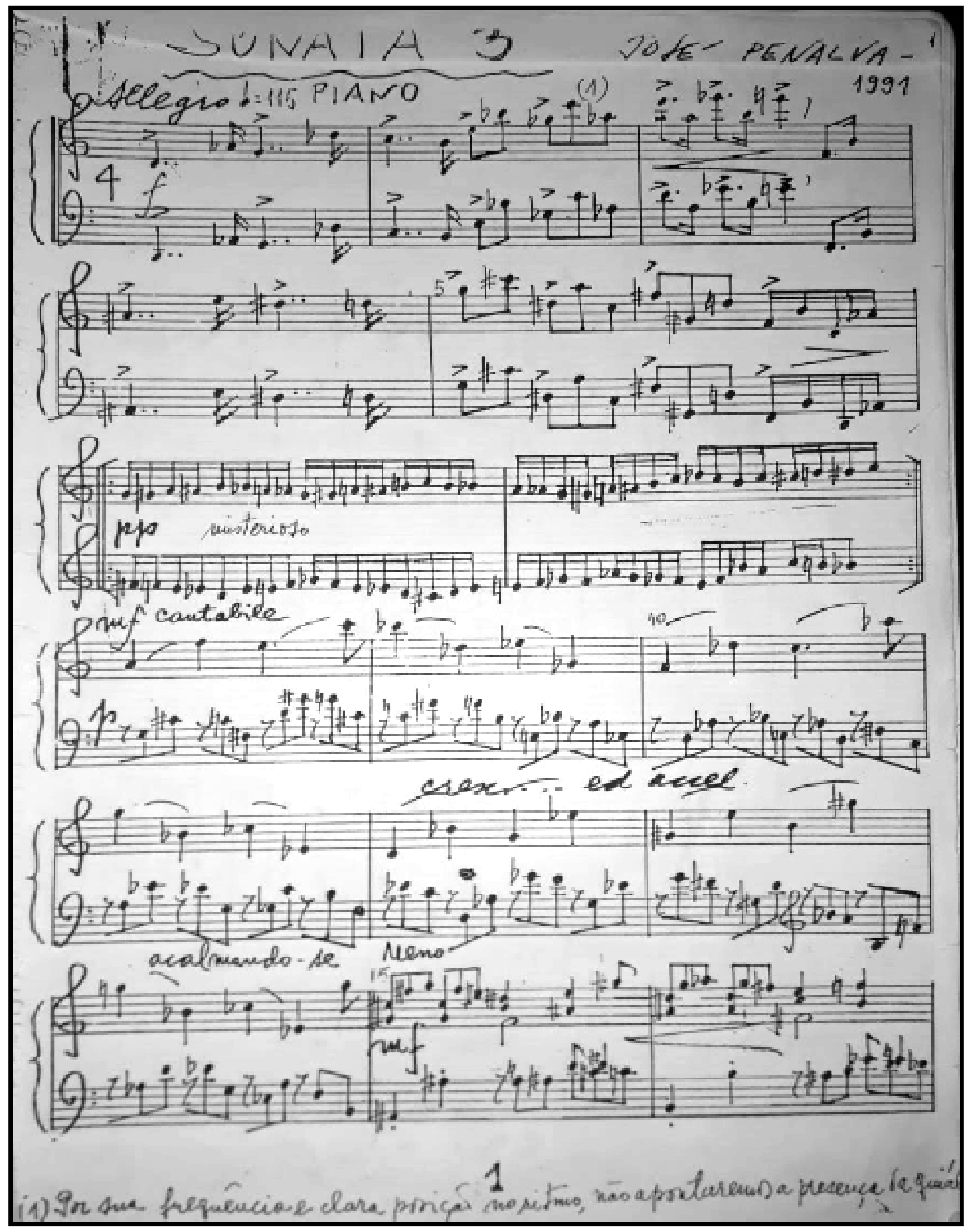




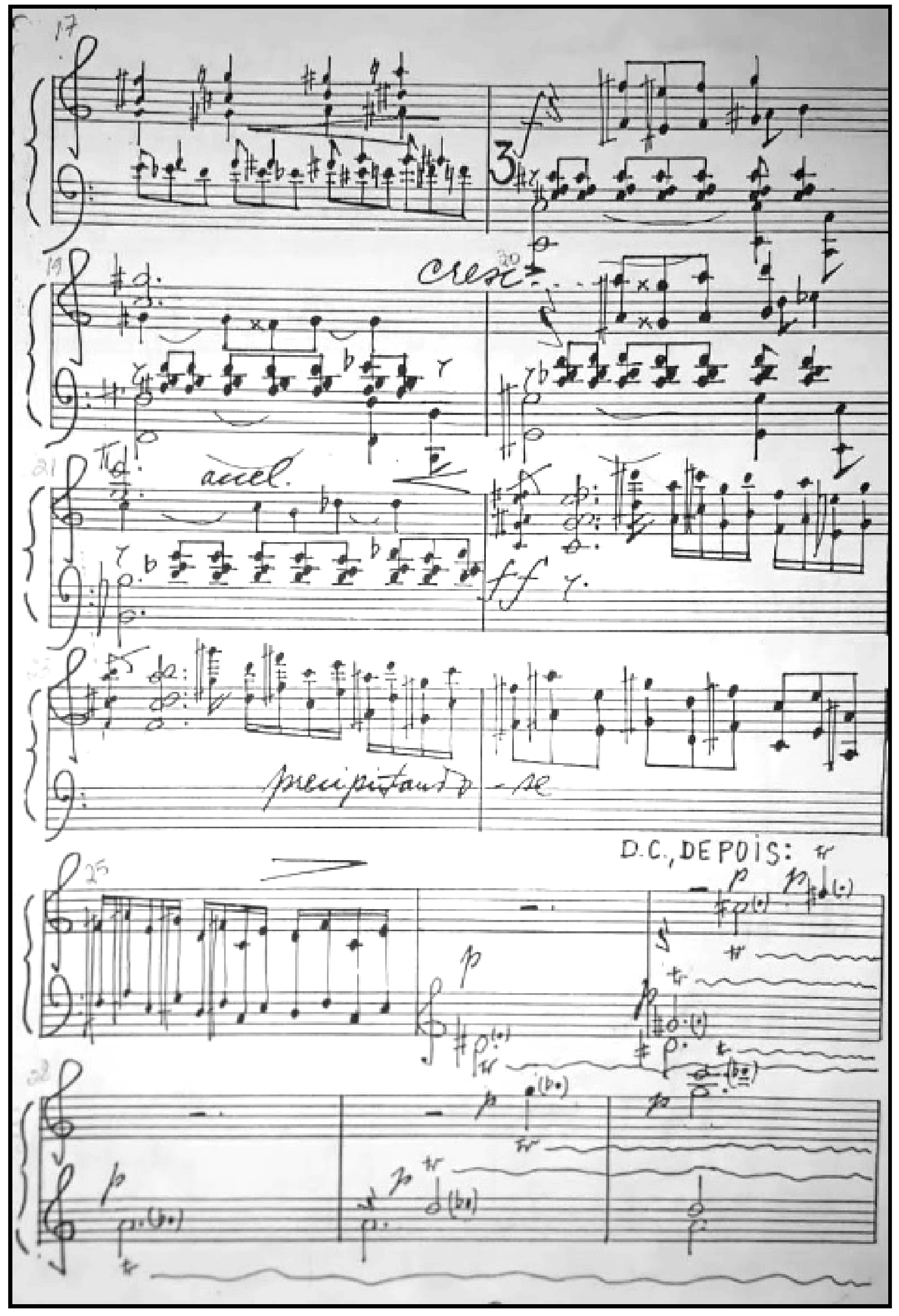




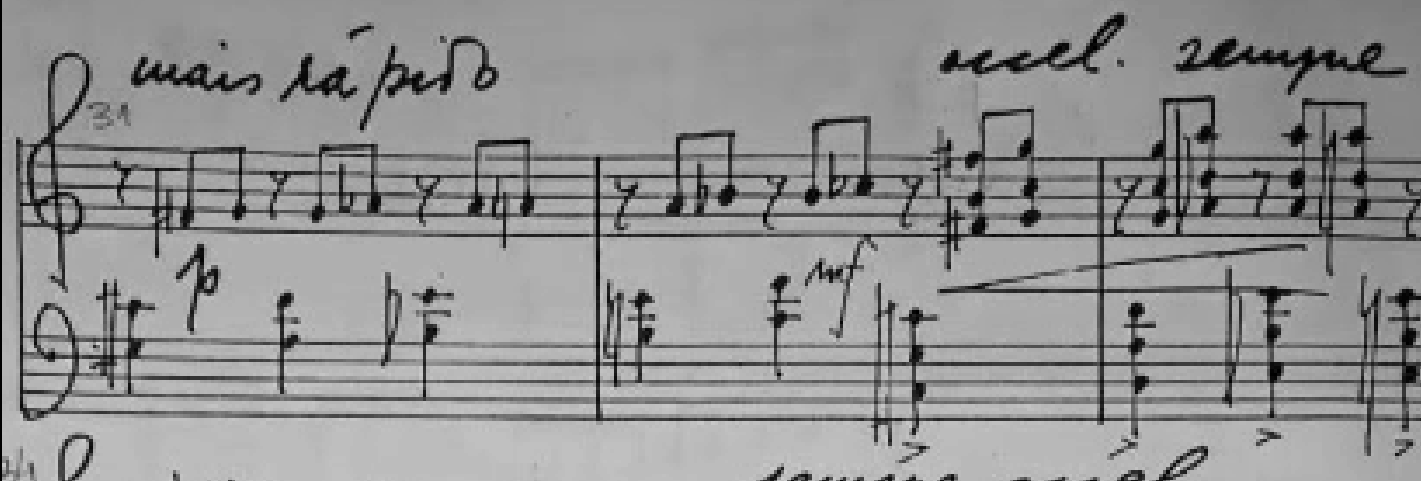

if hyts sempe acele.

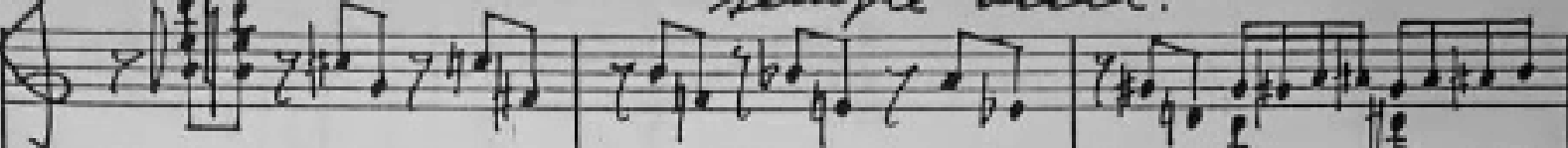

$\frac{0 \div}{2} \div$

(5)

$=\frac{1}{7 !}$

3 


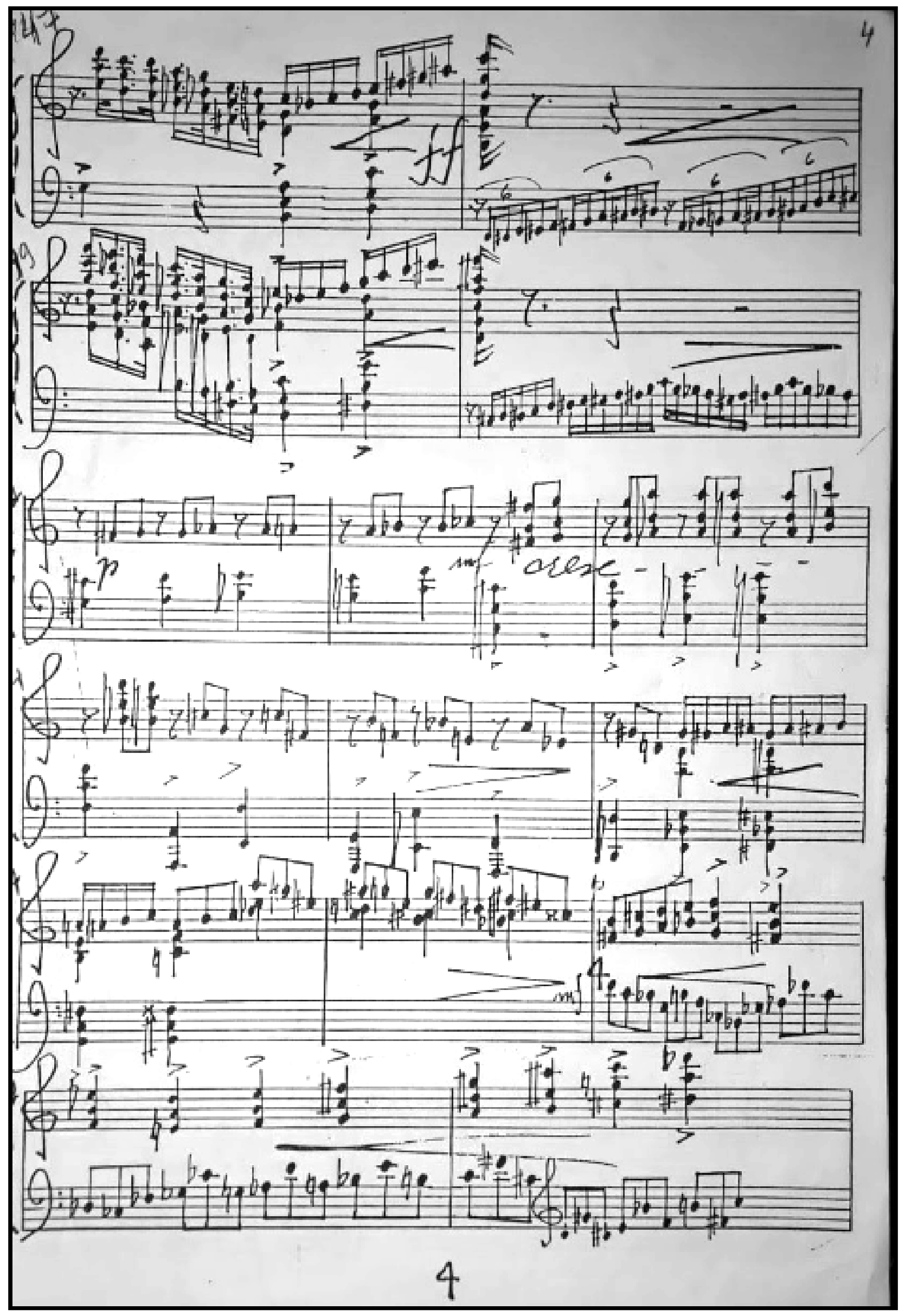




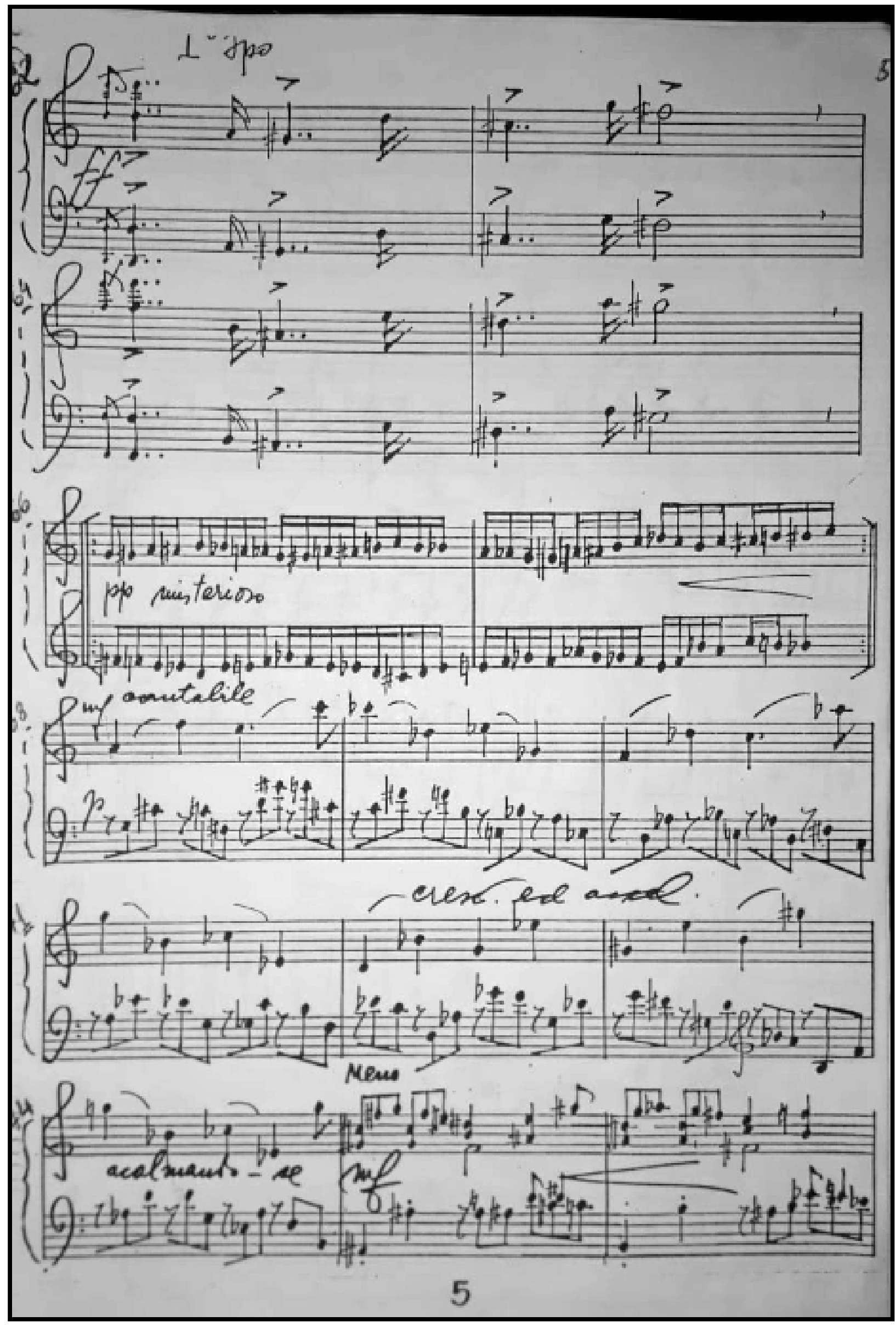




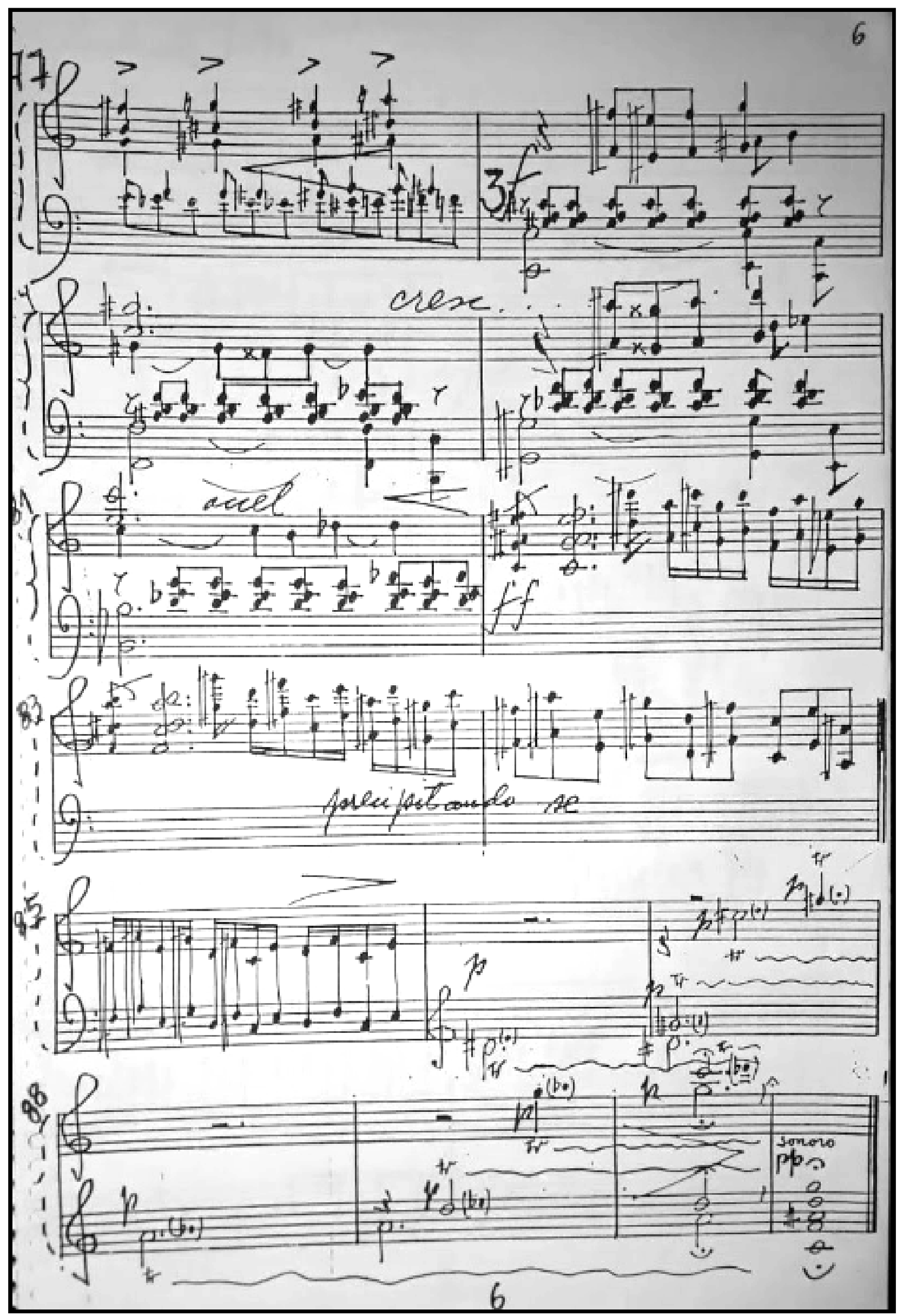




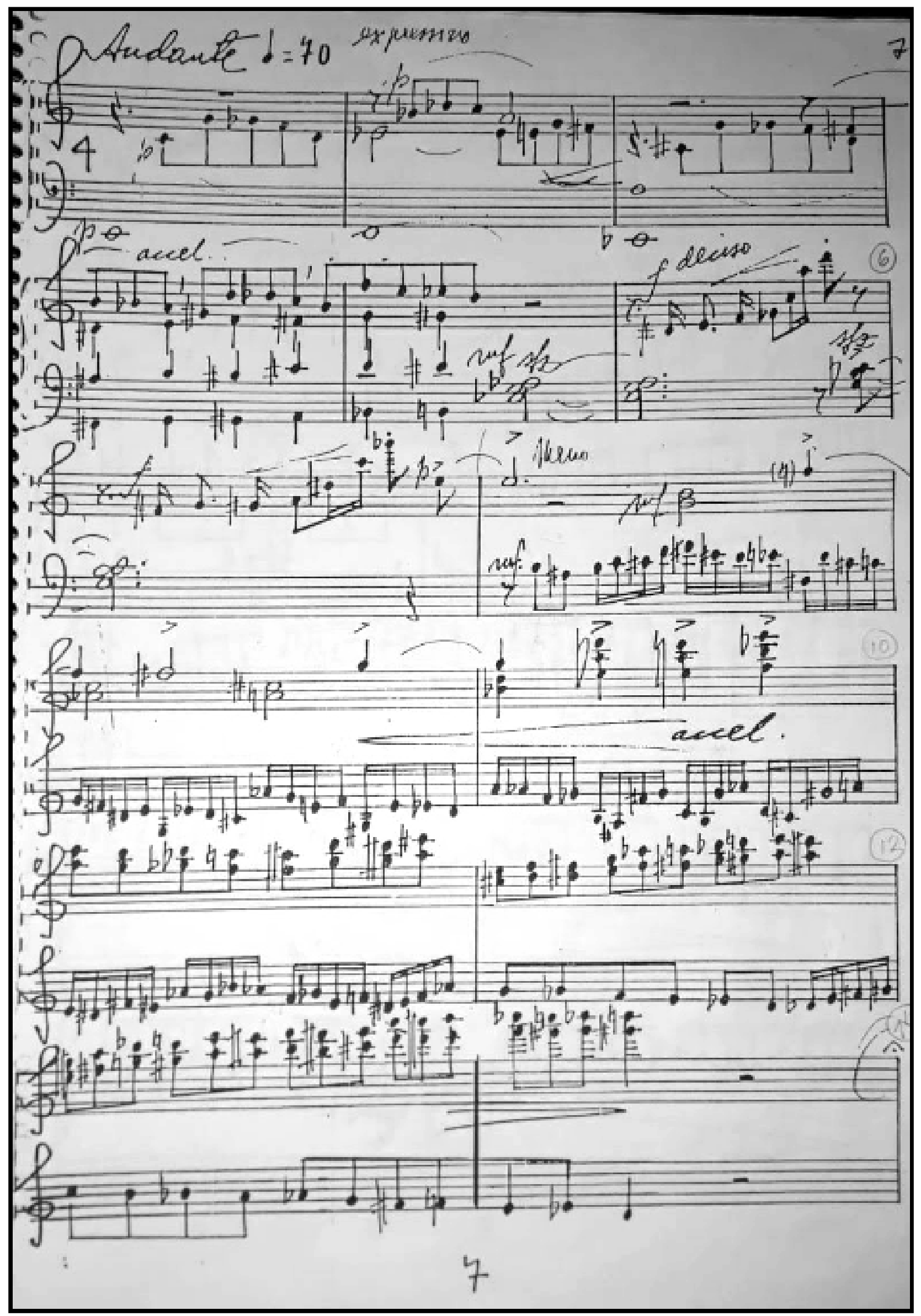




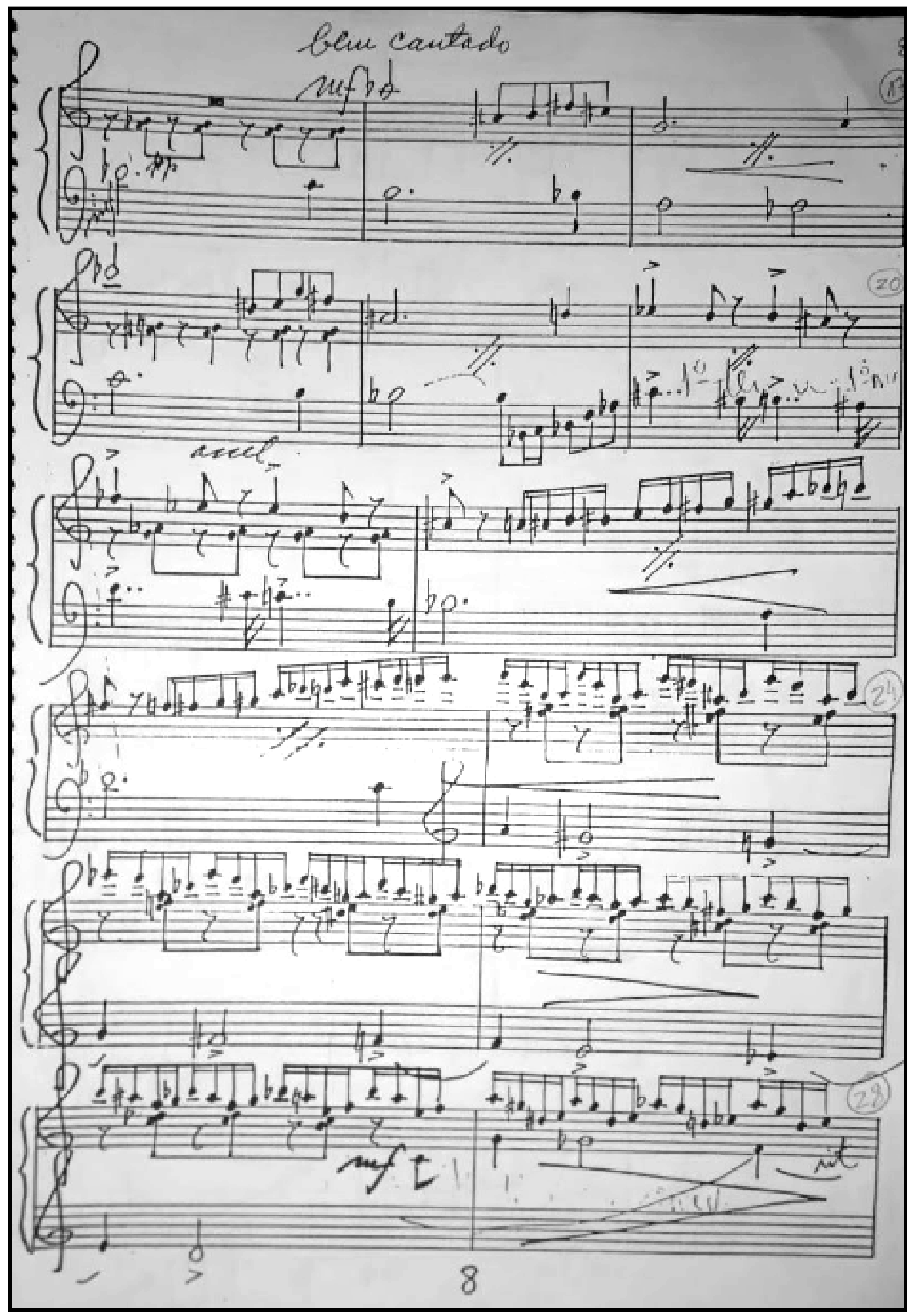




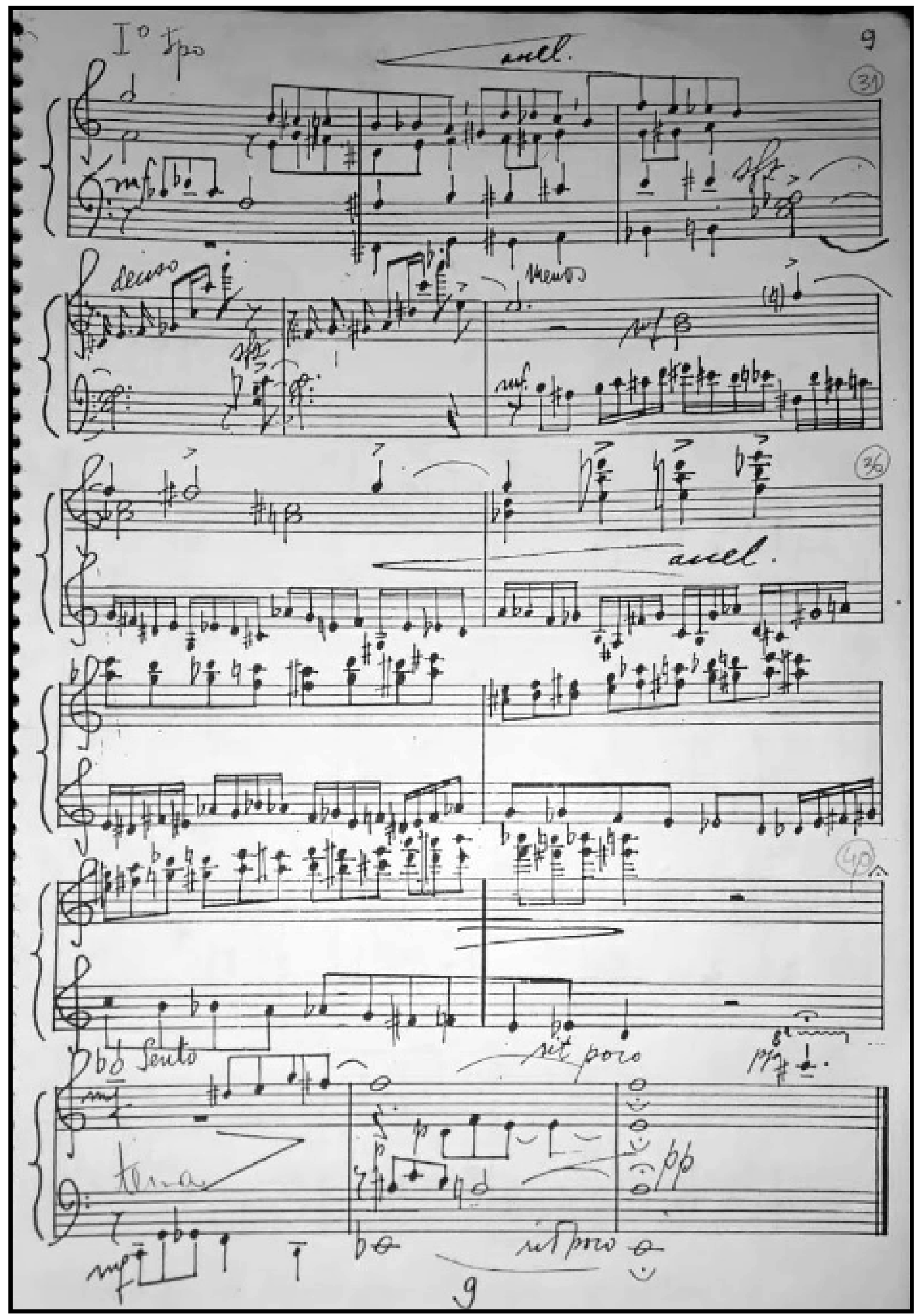




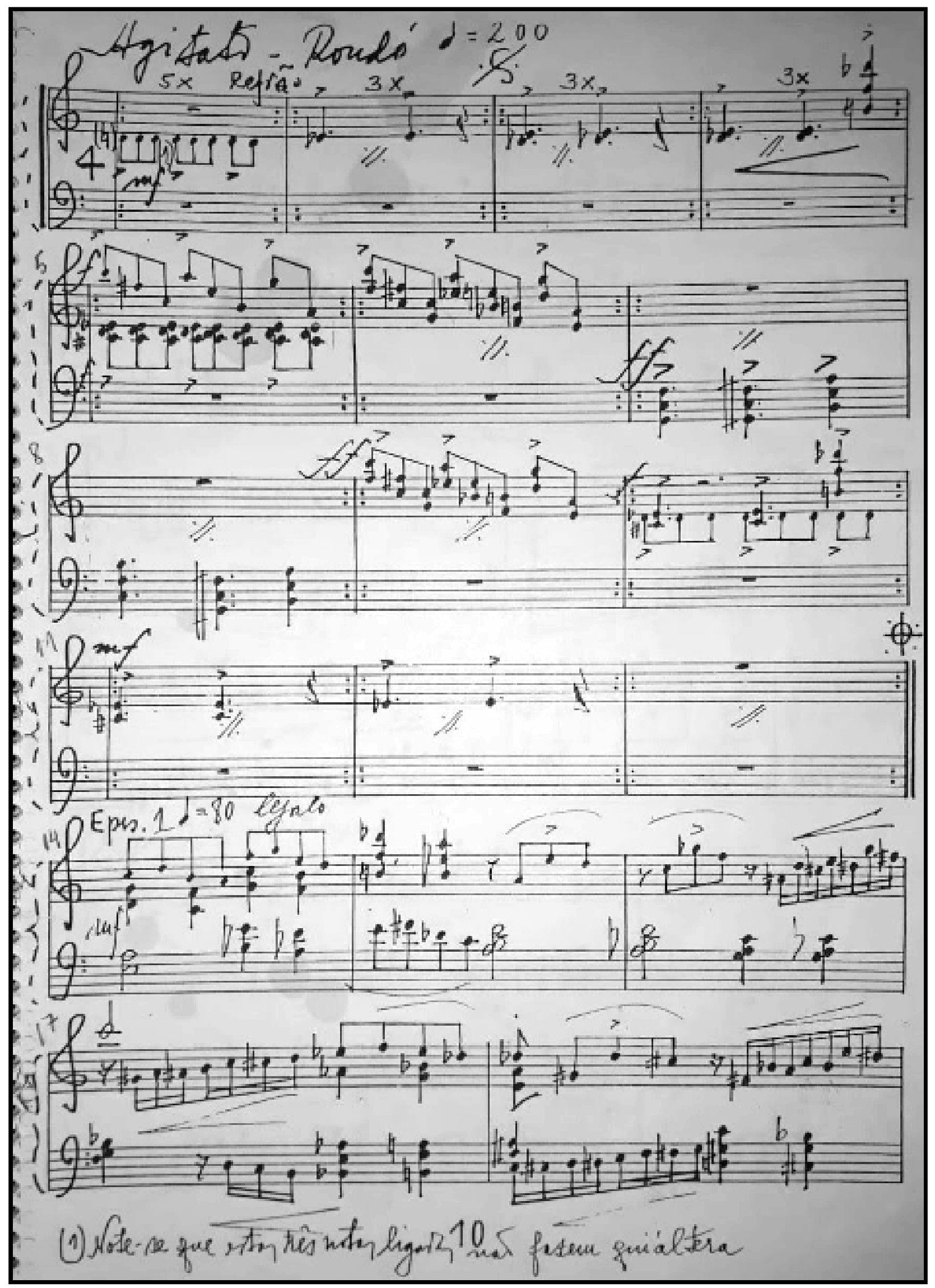




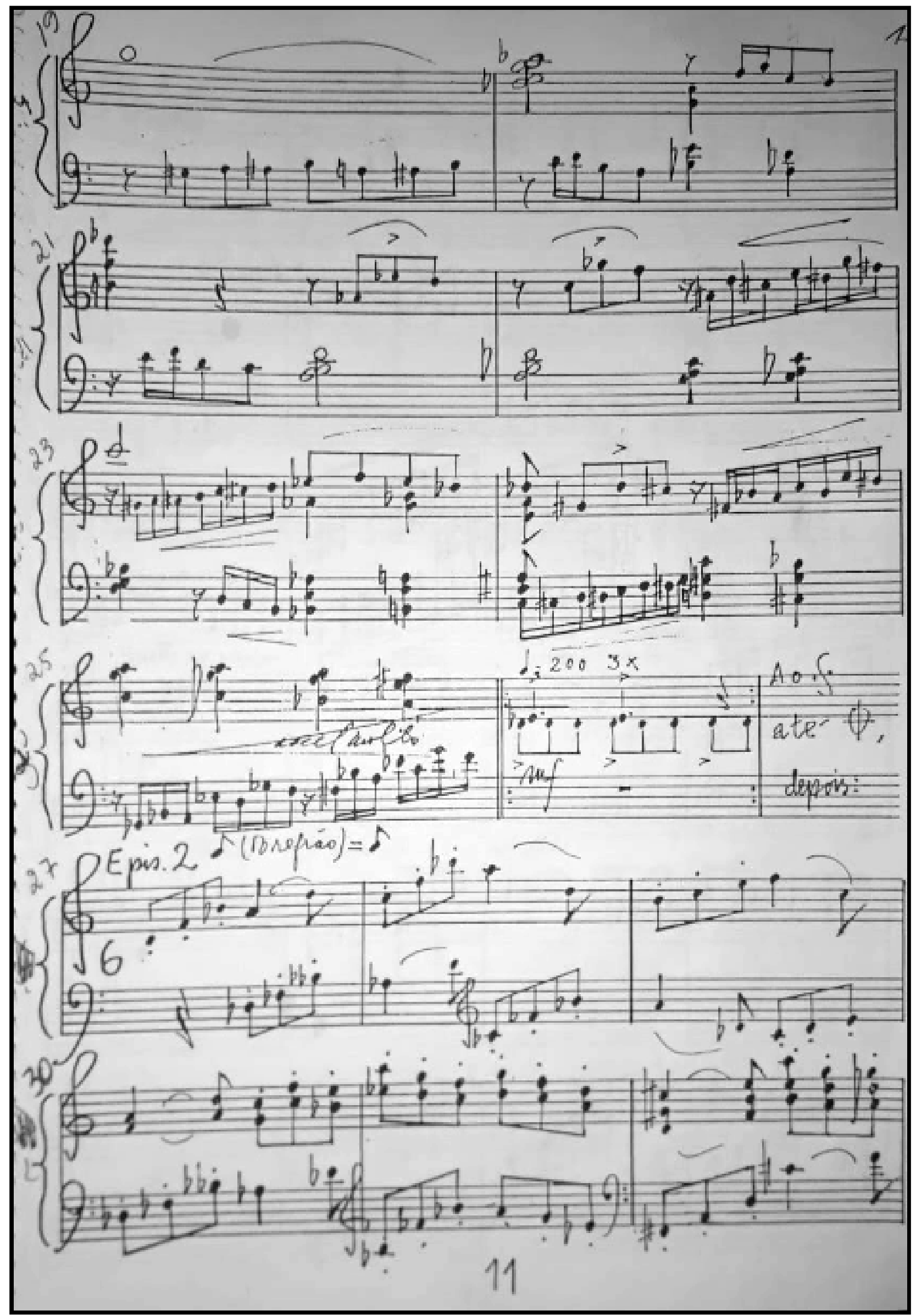




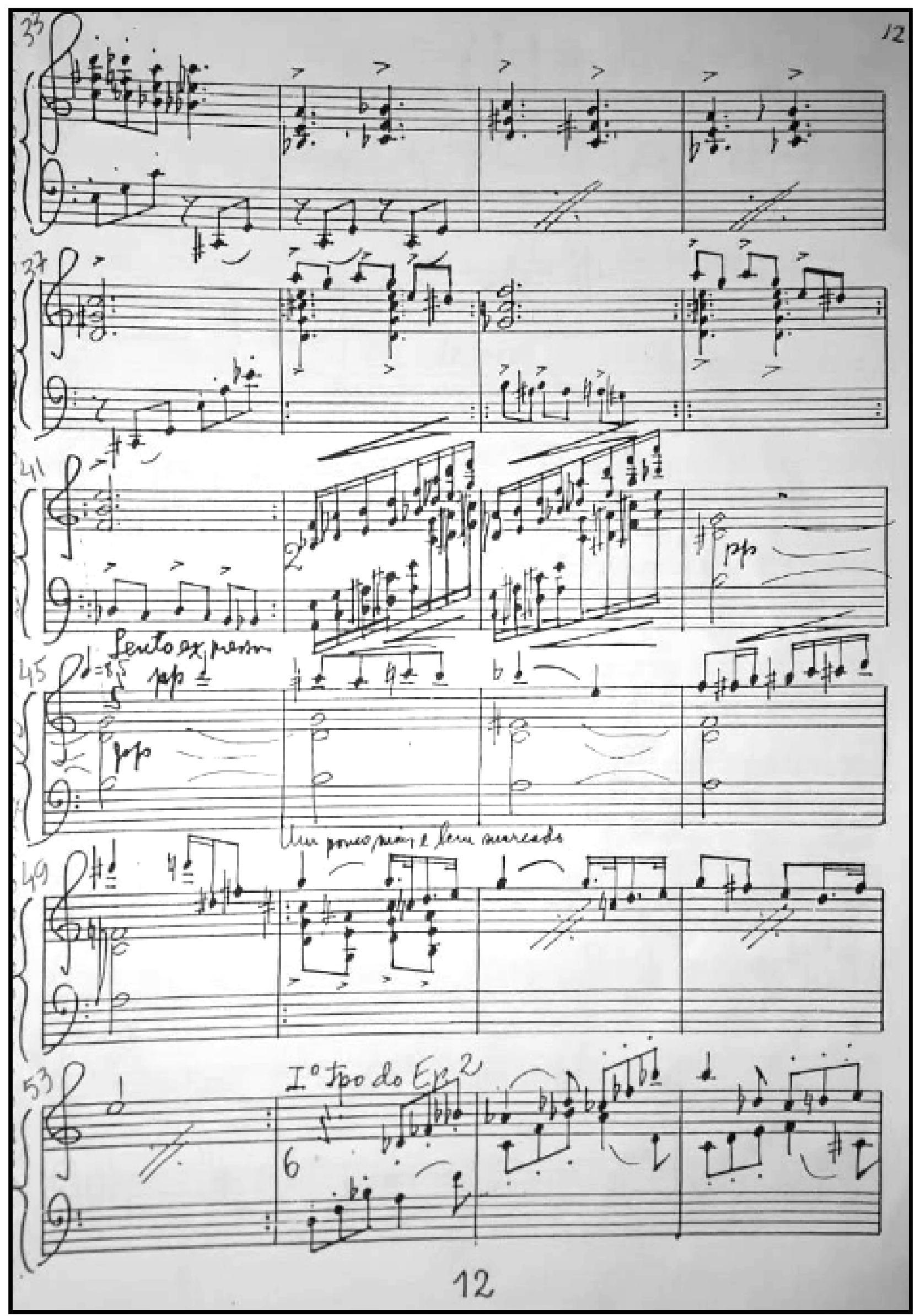




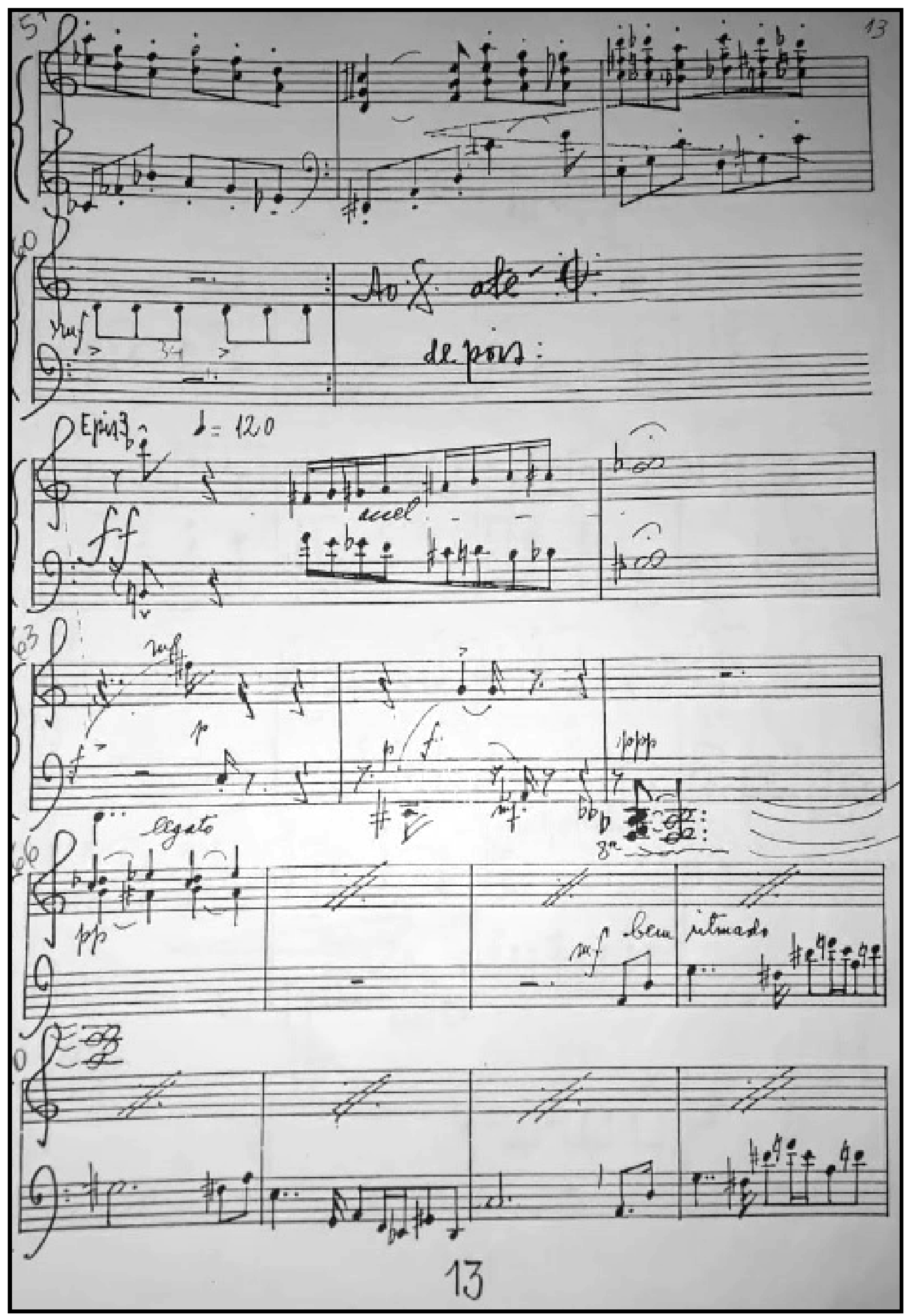




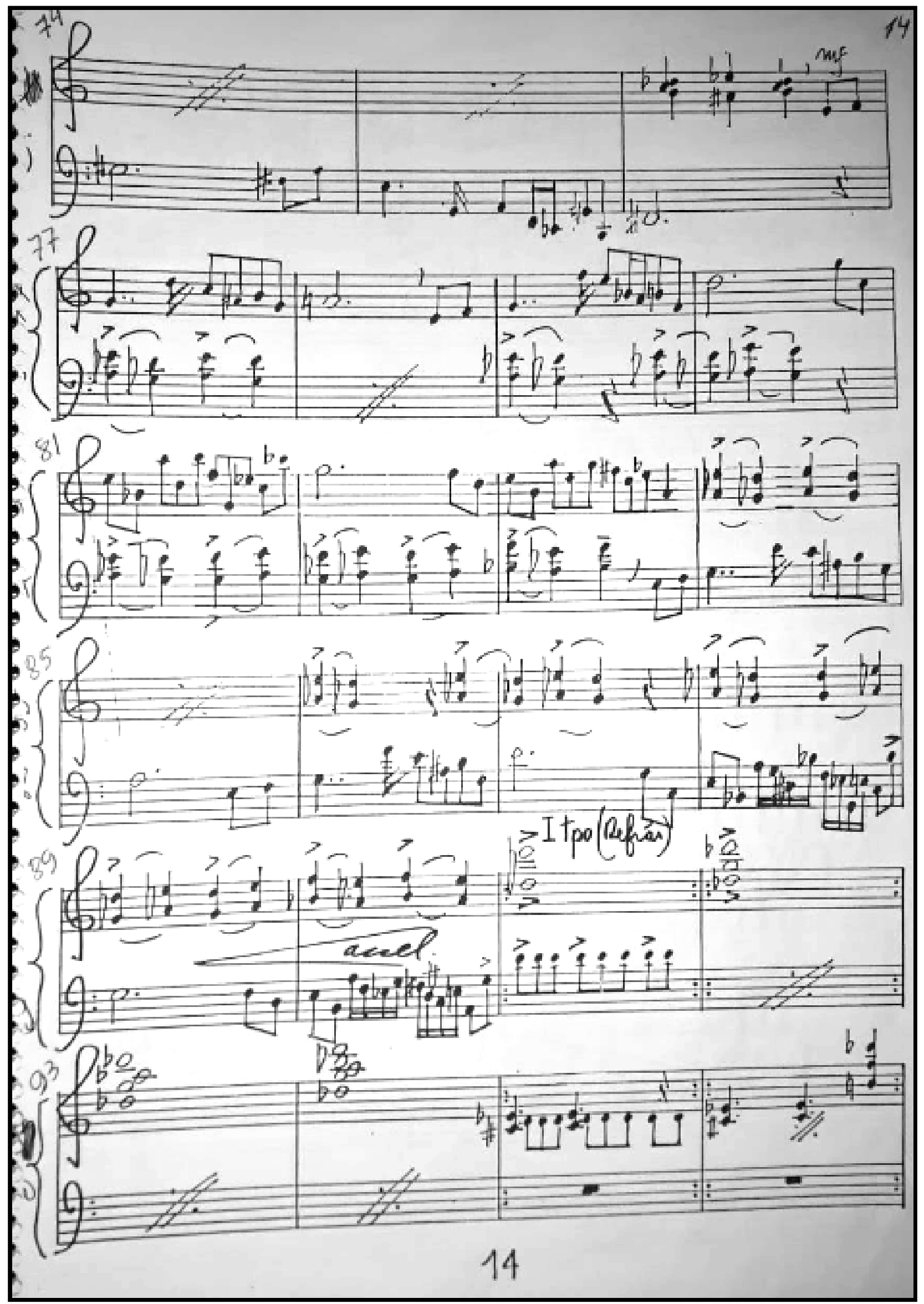




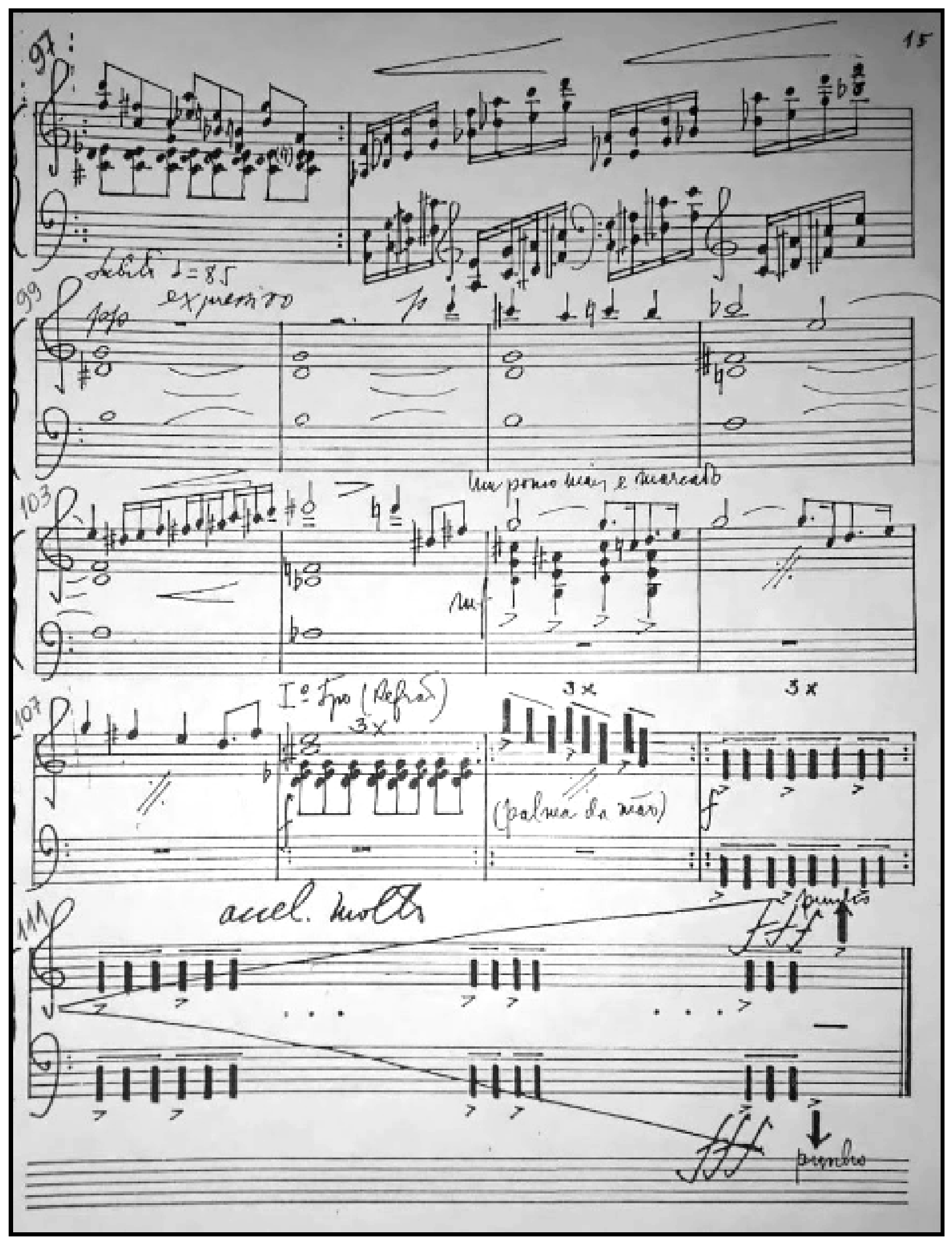




\section{Appendix 4 - Penalva Bagatelas (Unknown Manuscripts)}

\subsection{Bagatela I (manuscript, 1999)}

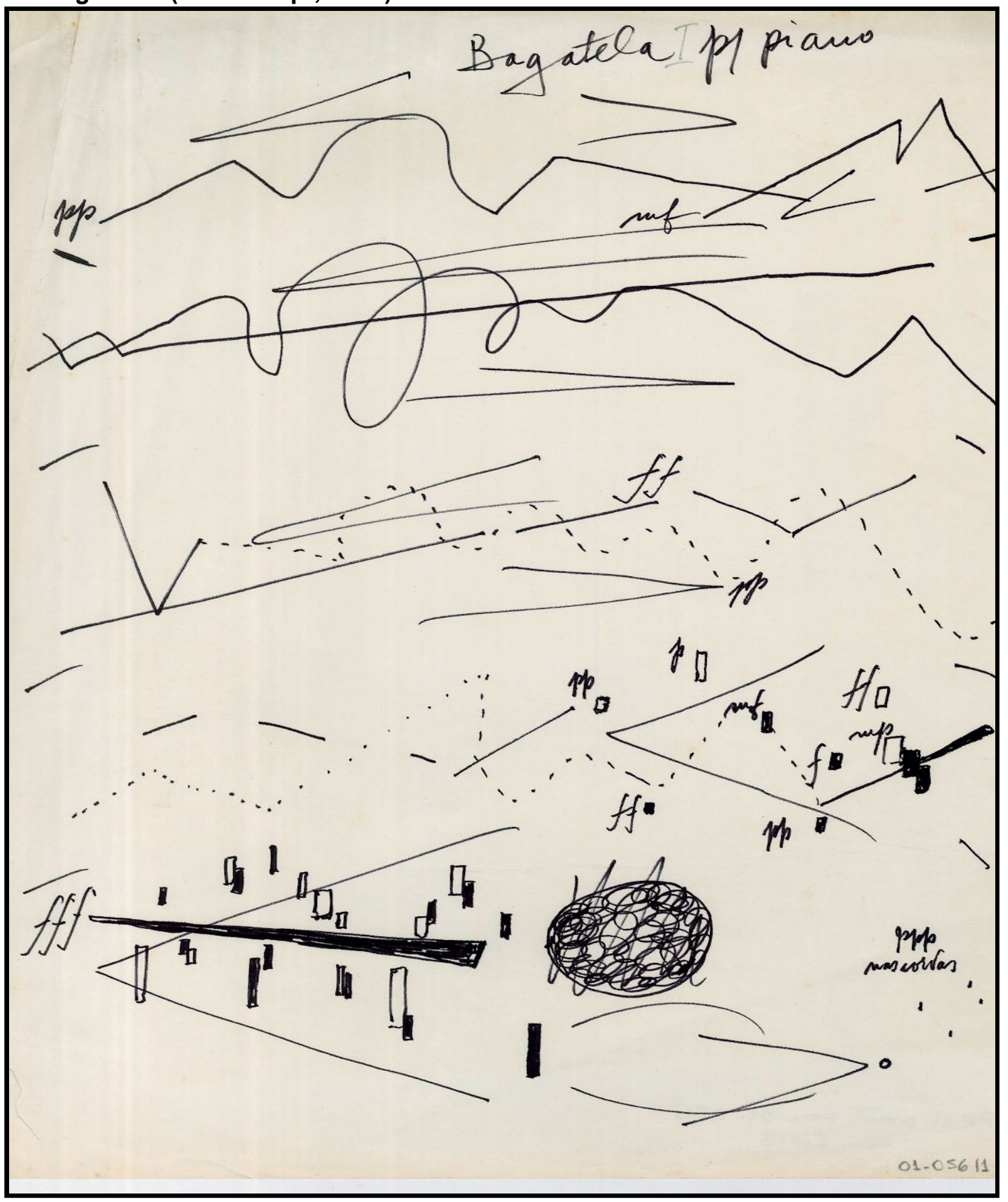




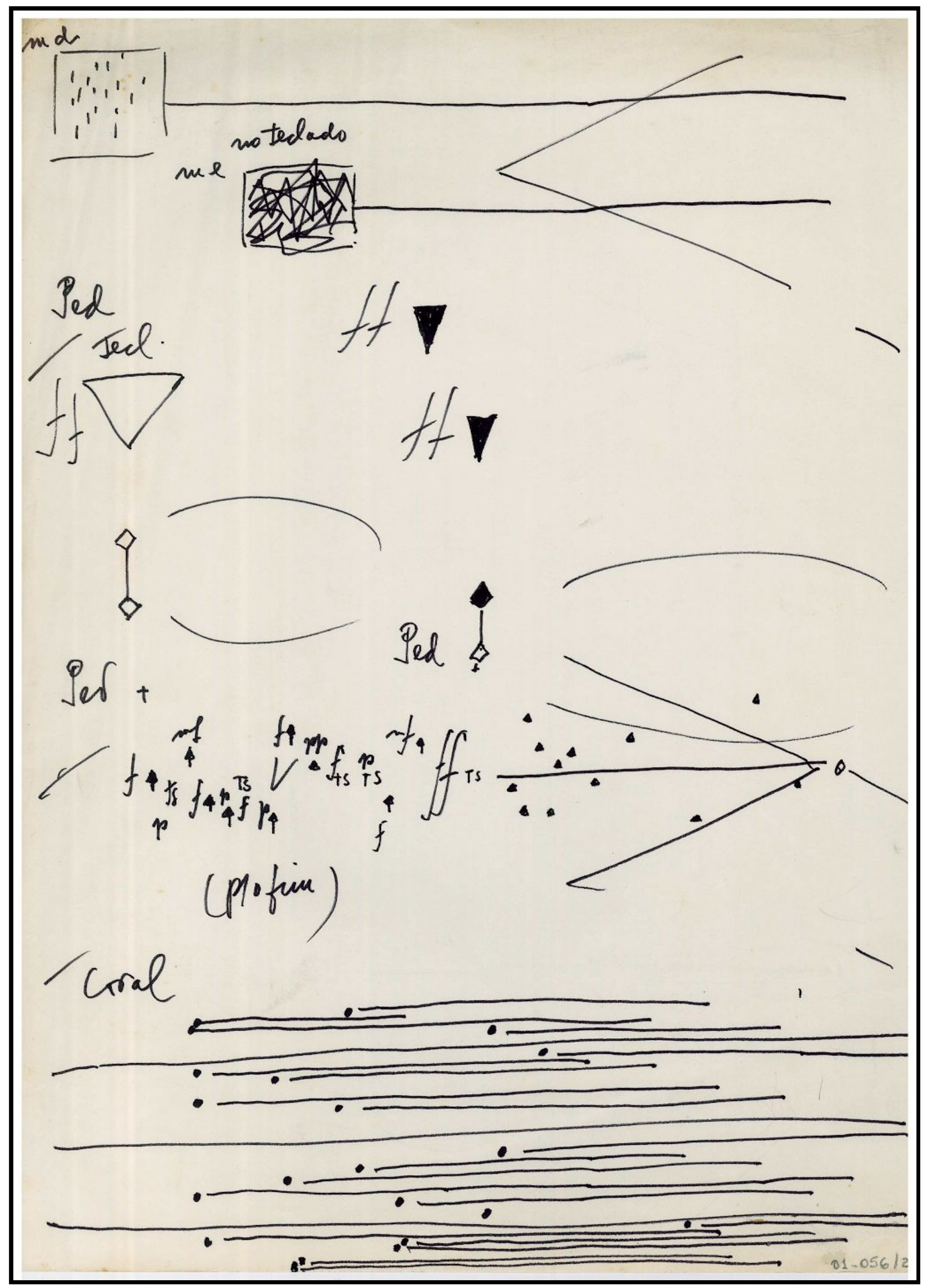


4.2 Bagatela II (manuscript, 1999)

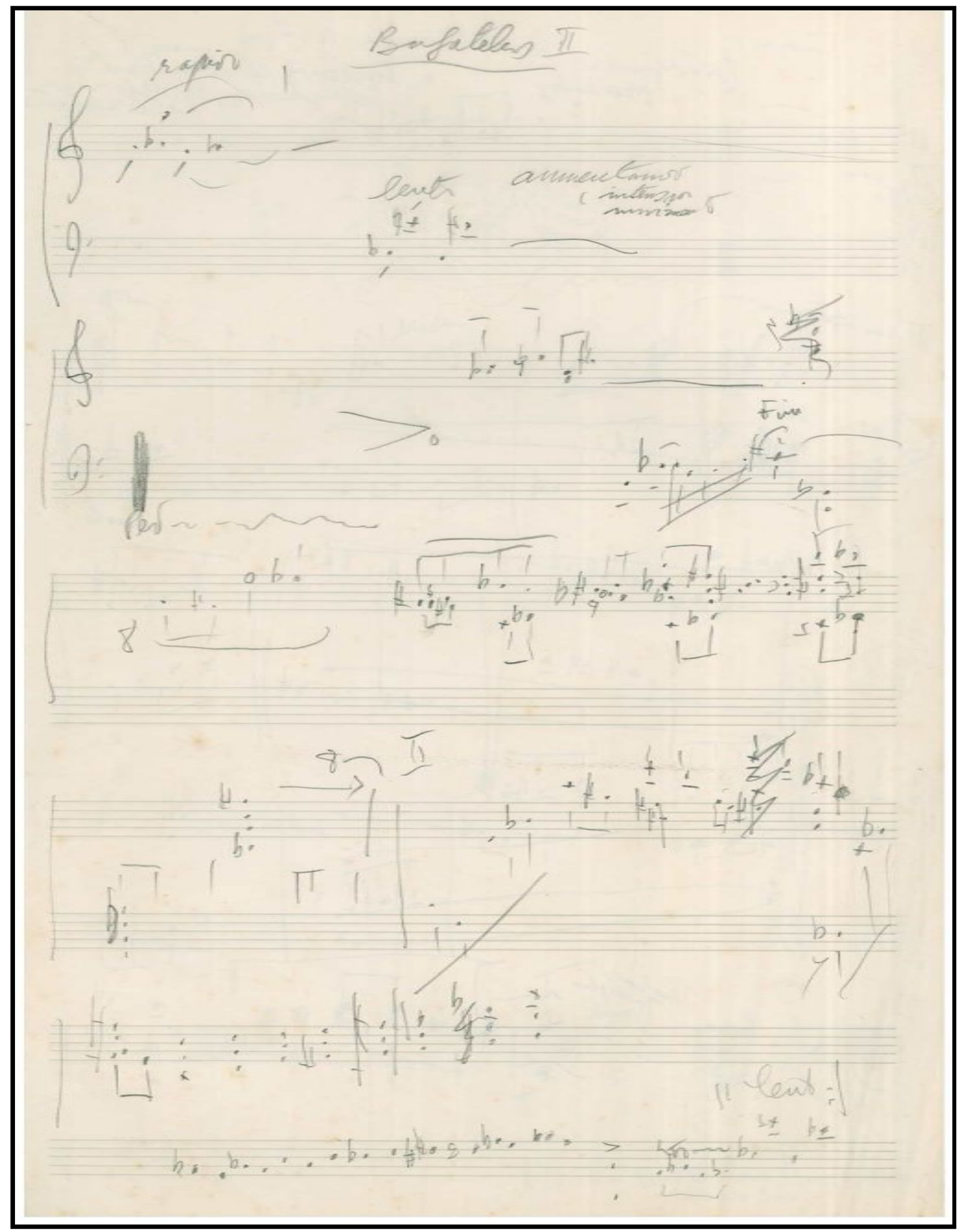




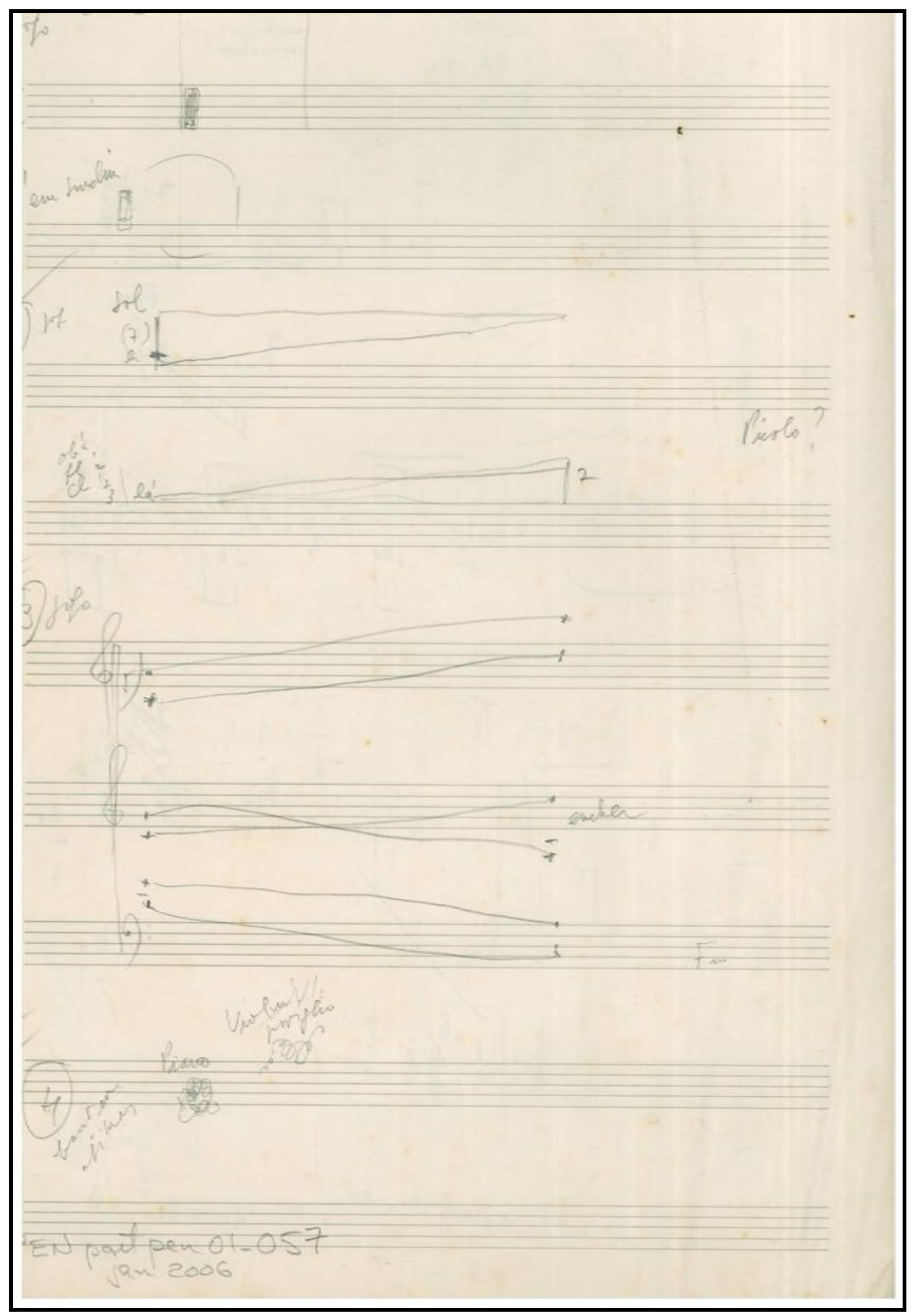


4.3 Bagatela III (manuscript, 1999)

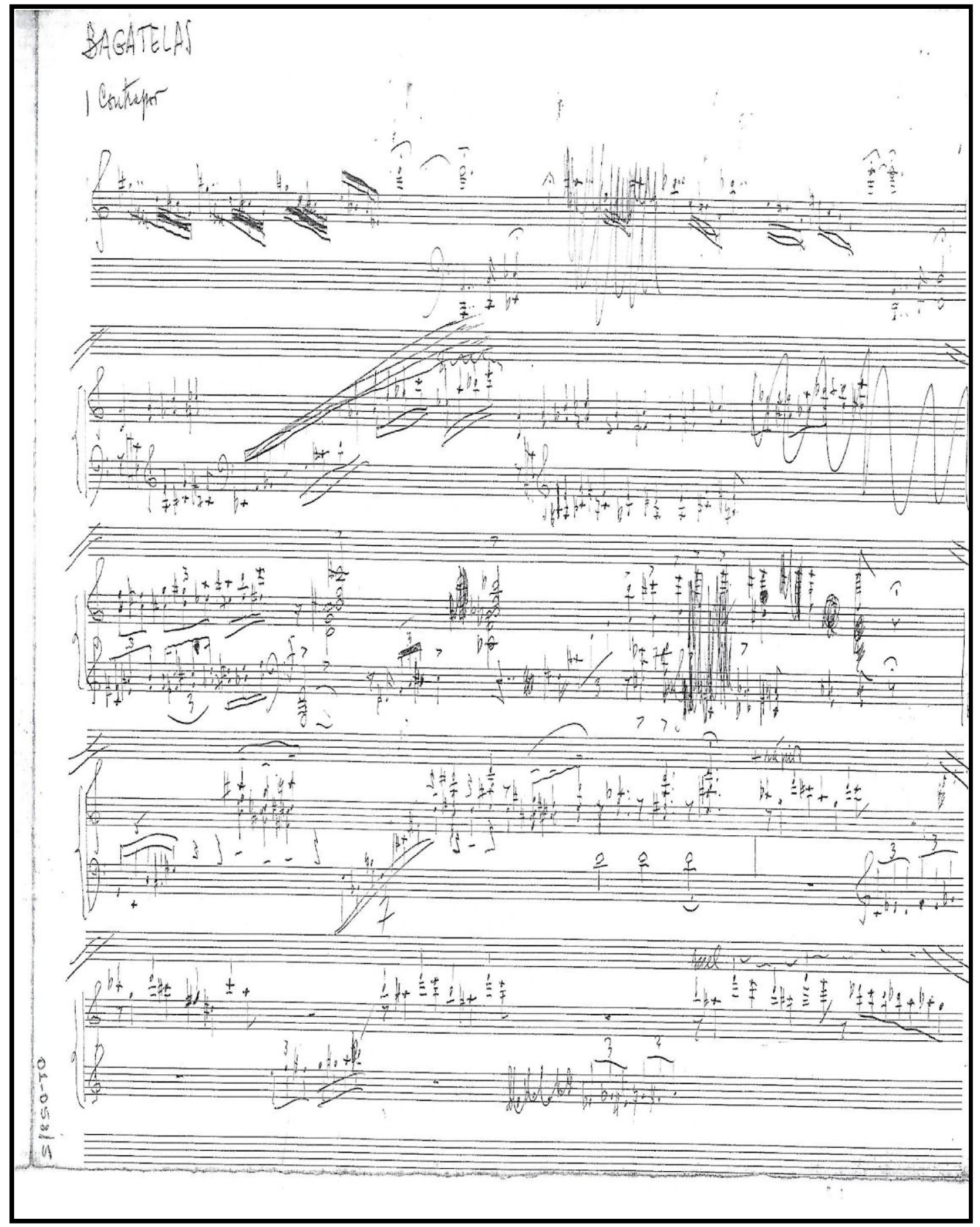




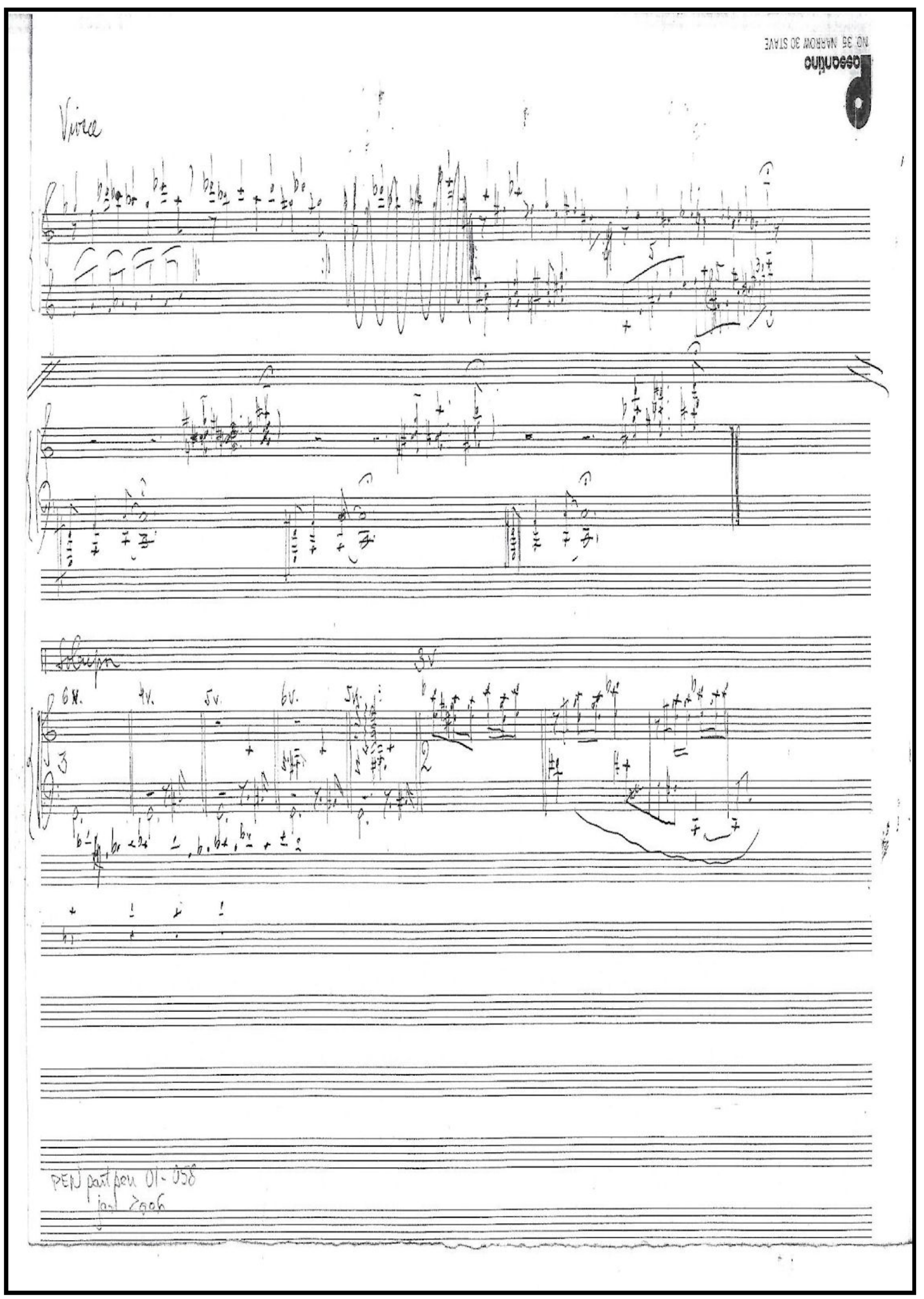


4.4 Bagatela IV (manuscript, 1999)

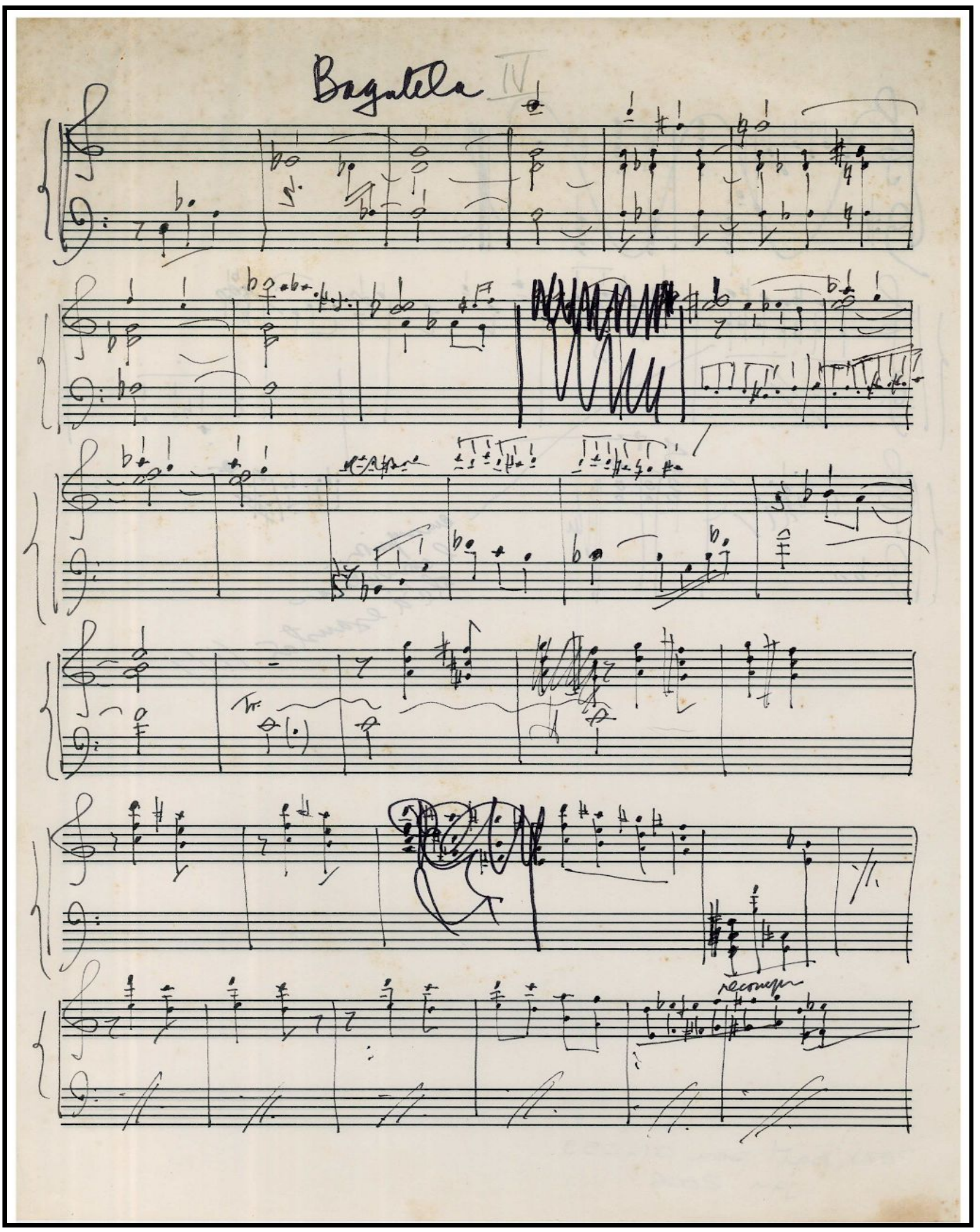




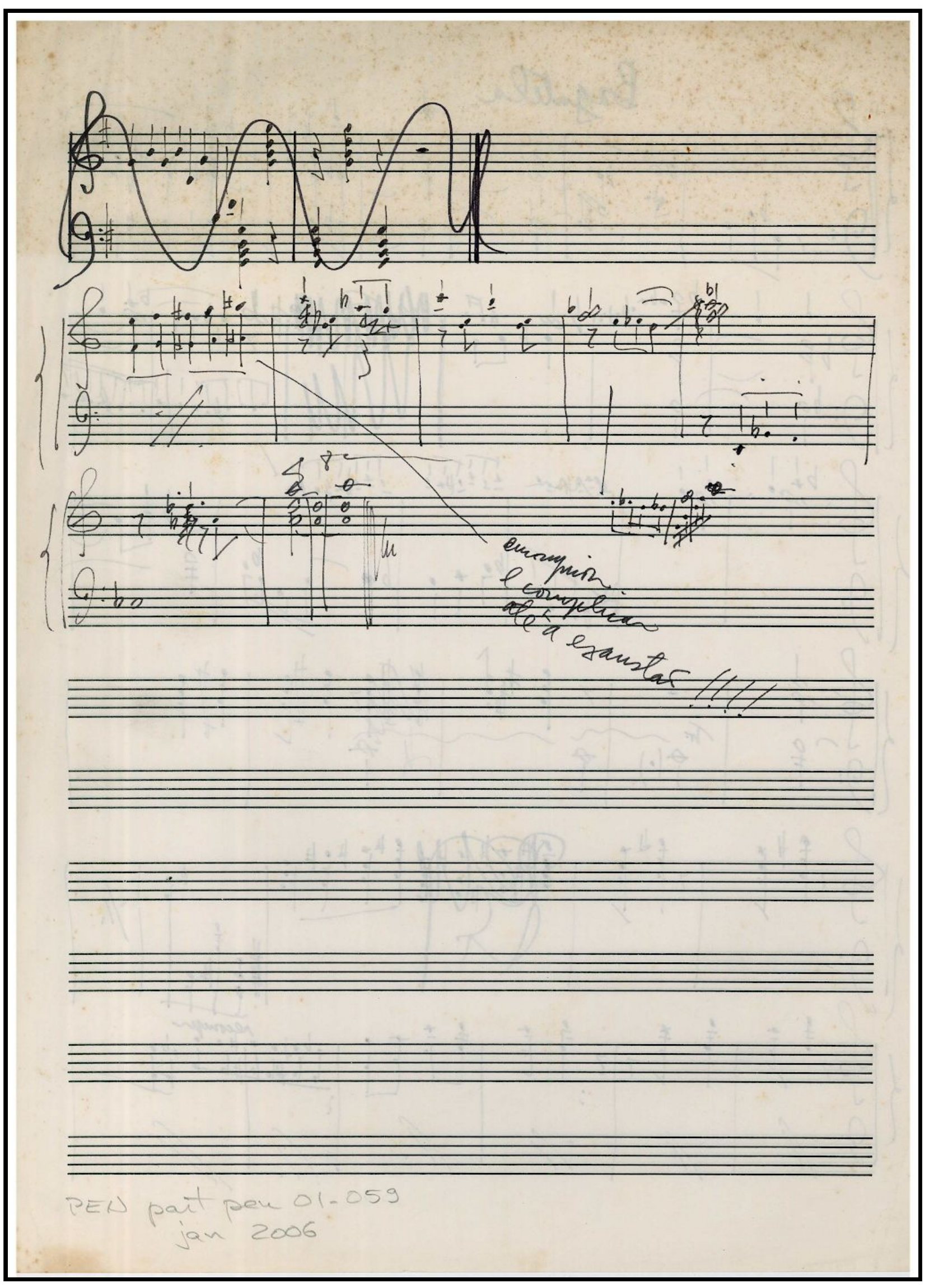




\subsection{Bagatela $V$ (manuscript, 2000)}

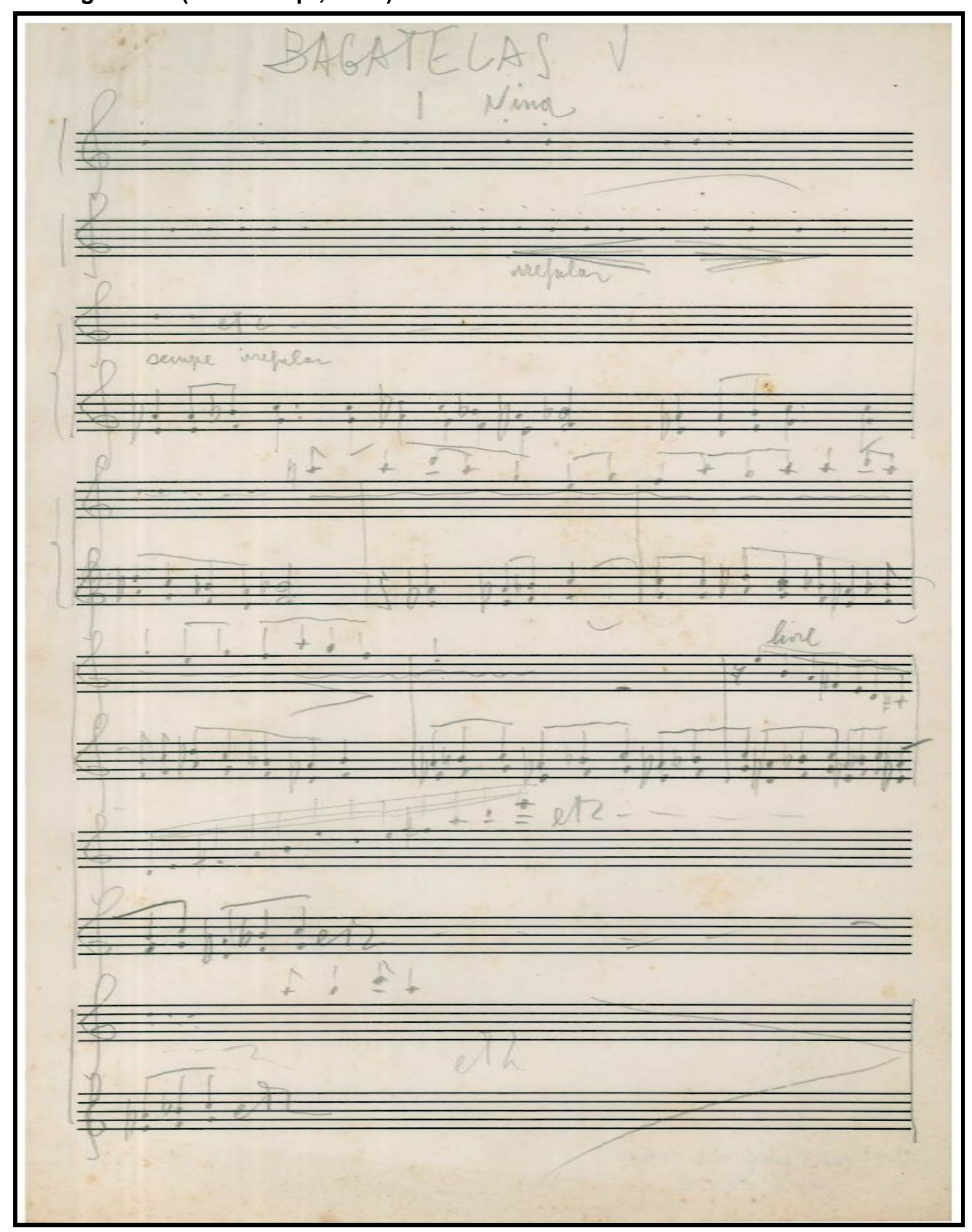




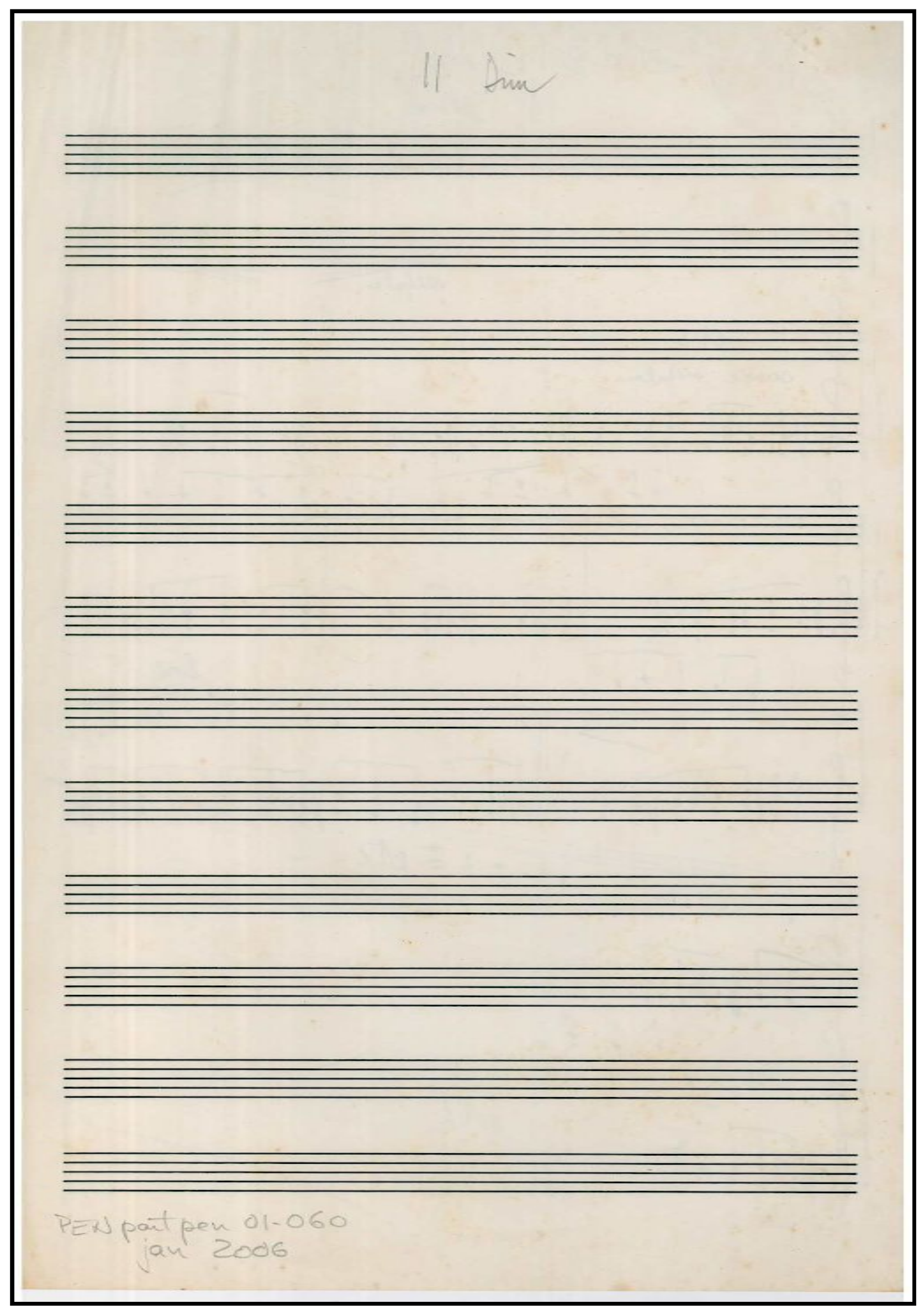




\subsection{Bagatela VI (manuscript, 2000)}

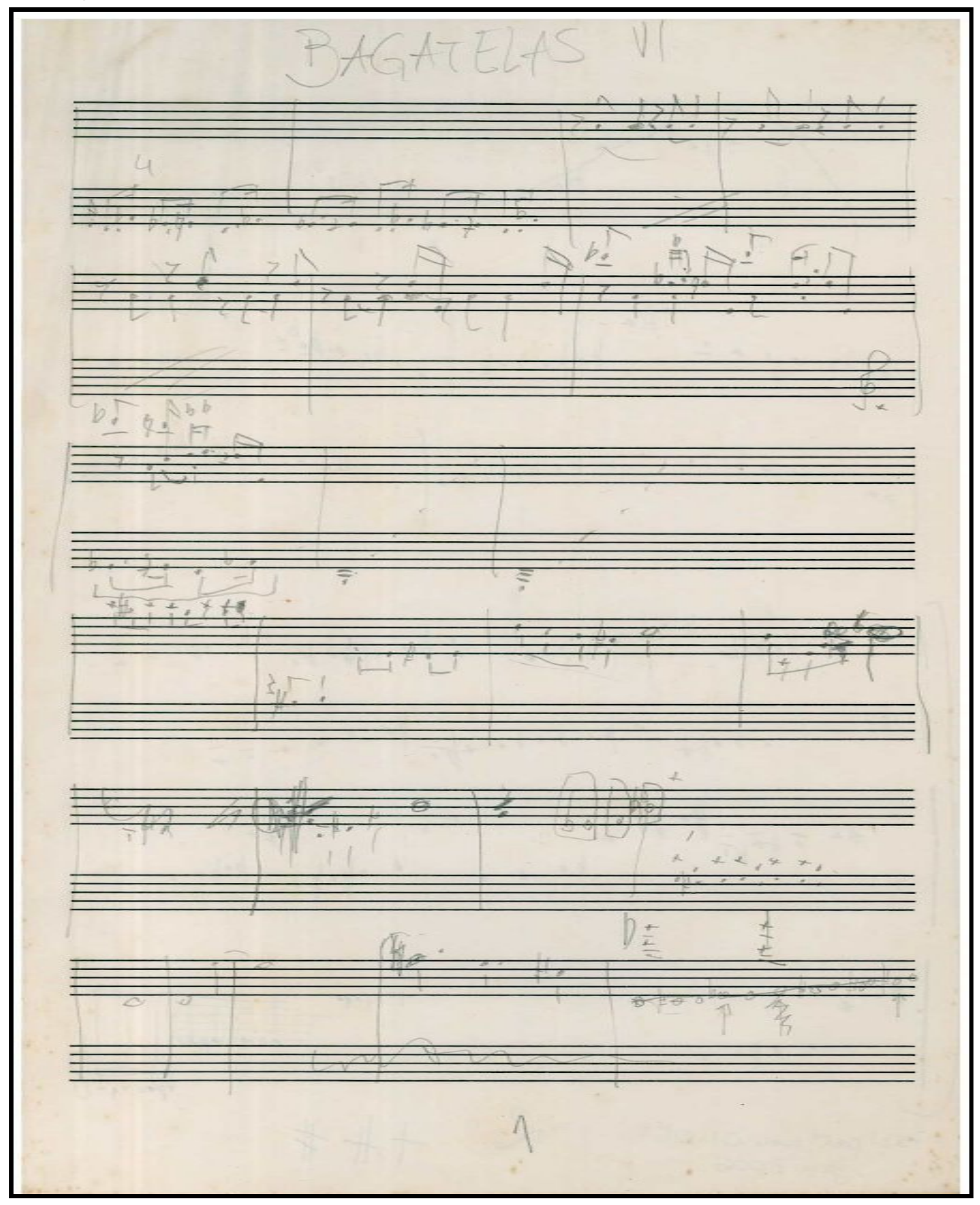




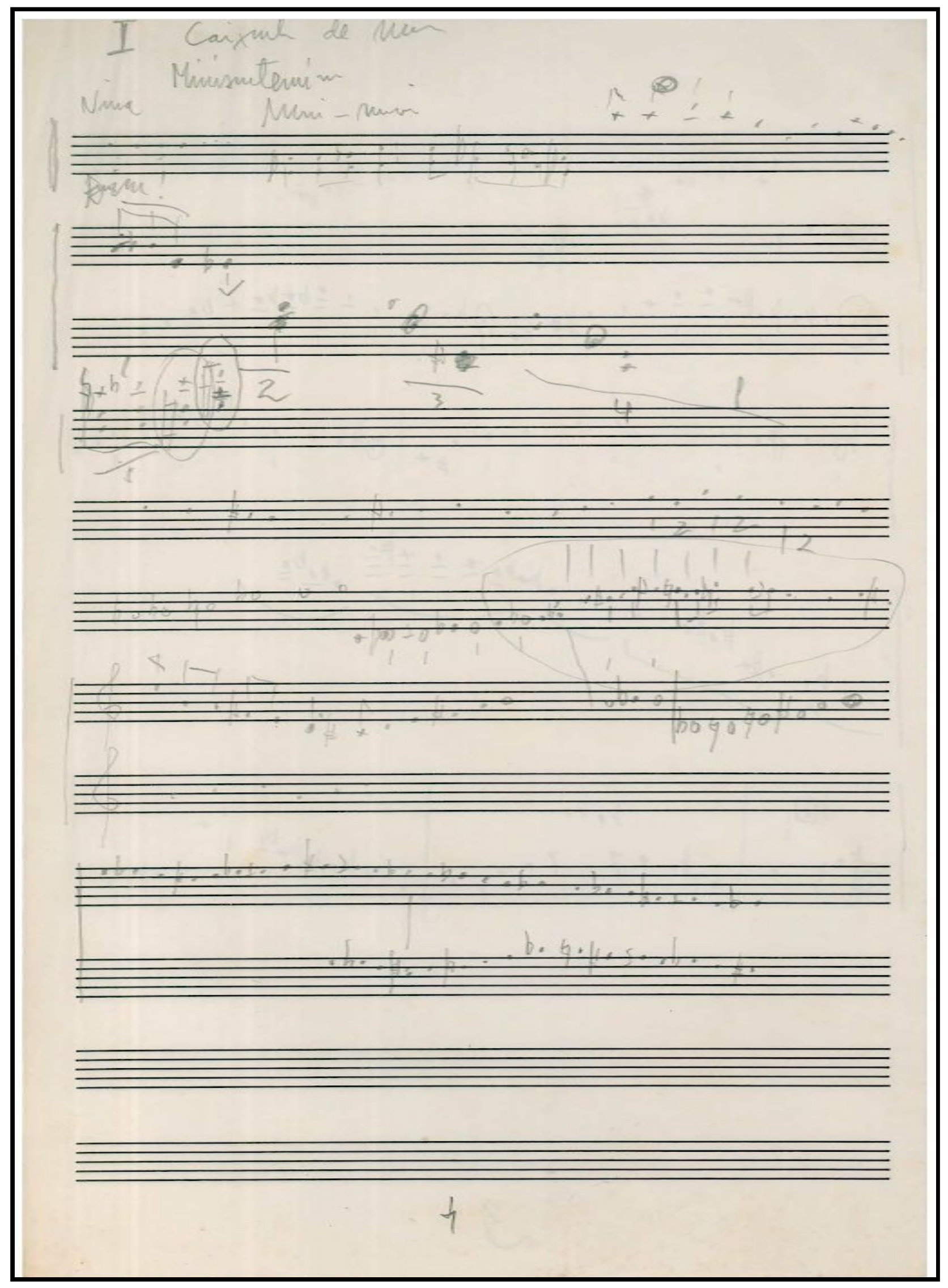


Appendix 5 - List of Portuguese Terms, as They Appear in Penalva's Manuscripts

\section{Sonata no.1}

Page 1

- seresta: serenade (Brazilian musical genre).

- desafio: challenge, fight (Brazilian musical genre).

- moderadamente: moderato.

- acel. (acelerando): speeding up.

- retard. um pouco: slightly slowing down.

- menos: less.

- muito expressivo: very expressive.

\section{Page 2}

- Ped. sempre: always with pedal.

- crescendo e acelerando: crescendo and speeding up.

- 8a sempre: always one octave lower

- Continua Pedal sempre: always keep using the pedal.

- Sonoridade máxima: maxim sonority.

- cantando bem: very cantabile

\section{Page 3}

- acelerando: speeding up.

- acelerando loucamente: madly speeding up.

- sêco: dry.

- sem pedal: no pedal.

\section{Page 4}

- à vontade: at ease (ad libitum).

- mais: louder

- acel. (acelerando): speeding up.

\section{Page 5}

- galhofeiro: joker. 


\section{Page 6}

- cresc. e acelerando sempre: always crescendo and speeding up.

- decidido: decisively.

\section{Page 7}

- acelerando: speeding up.

- devagar: slowly.

- suave: soft.

- Violento: violent.

- movimento anterior: previous tempo.

- misterioso: mysterious.

- rápido: fast.

- Lento: slow.

\section{Sonata no.2}

\section{Page 2}

- cantando bem: very cantabile.

\section{Page 5}

- Primeiro Tempo: first (initial) tempo.

\section{Page 8}

- súbito: sudden.

- melodioso e sonoro: melodious and sonorous.

\section{Page 9}

- conciso: concise.

- amplo: wide. 


\section{Sonata no. 3}

\section{Page 1}

- Por sua frequência e clara posição no ritmo, não apontaremos a presença da quiáltera: For the reason of its steadiness and clear rhythm position, we will not point out the triplets.

- misterioso: mysterious.

- acalmando-se: calming down.

\section{Page 2}

- precipitando-se: precipitating.

- D.C., depois: Da capo, and after (and following that).

\section{Page 3}

- Mais rápido: faster.

- sempre accel.: always speeding up.

- robusto: robust, lusty.

\section{Page 5}

- misterioso: mysterious.

\section{Page 6}

- crescendo e acelerando: crescendo and speeding up.

- acalmando-se : calming down.

\section{Page 7}

- precipitando-se: precipitating.

- expressivo: expressive.

- deciso: decisive.

\section{Page 8}

- bem cantado: very cantabile. 
Page 9

- Primeiro tempo: first tempo (initial tempo).

- deciso: decisive.

\section{Page 10}

- Lento: slow.

- Note-se que estas três notas não fazem quiálteras: Notice that these three notes all together, do not set up a triplet.

\section{Page 11}

- Episódio: episode.

\section{Page 12}

- Ao: to.

- até: untill.

- depois: after (following that).

- do refrão: refrain's (eighth note).

\section{Page 13}

- Lento e expressivo: slowly and expressive.

- Um pouco mais e bem marcado: a little more (louder) and very articulated.

\section{Page 14}

- bem ritmado: very rhythmical.

\section{Page 15}

- Primeiro tempo (refrão): Initial tempo (refrain).

- Súbito: sudden.

- Palma da mão: palm of hand.

- punho: handgrip. 


\section{Bibliography}

"A Obra Solística Para Piano, Órgão e Cravo de José Penalva." Accessed February 12, 2020. http://www.rem.ufpr.br/_REM/REMv1.2/vol1.2/penalva.html.

Albrecht, Cintia Macedo; Pascoal, Maria lúcia. "Revista Eletrônica de Musicologia," 2004. http://www.rem.ufpr.br/_REM/REMv8/penalva.html.

"Anton Webern." In Wikipedia, January 26, 2020.

https://en.wikipedia.org/w/index.php?title=Anton_Webern\&oldid=937680169

Page Version ID: 937680169.

"Antônio Carlos Gomes." In Wikipedia, December 28, 2019.

https://en.wikipedia.org/w/index.php?title=Ant\%C3\%B4nio_Carlos_Gomes\&oldi $\mathrm{d}=932794232$

Page Version ID: 932794232.

"Baião (música)." In Wikipédia, a enciclopédia livre, April 22, 2020.

https://pt.wikipedia.org/w/index.php?title=Bai\%C3\%A3o_(m\%C3\%BAsica)\&oldi $\underline{\mathrm{d}=58100476}$

Page Version ID: 5810047

Bojanoski, S. e Prosser, E. S. José Penalva: Uma vida com a batina e a batuta. Curitiba: Artes Gráficas e Editora Unificado, 2006.

Luis Iruarrizaga Abesbatza. "Biografia." Accessed April 21, 2020. http://www.iruarrizagabesbatza.eus/language/es/biografia-2/.

"Camargo Guarnieri." In Wikipedia, November 24, 2019.

https://en.wikipedia.org/w/index.php?title=Camargo_Guarnieri\&oldid=92771167 $\underline{7}$

Page Version ID: 927711677 
Campinas, IHGG. "História da moderna composição musical em Campinas: Paulo Florence e Padre José Penalva." Instituto Histórico, Geográfico e Genealógico de Campinas (blog), February 6, 2020.

https://ihggcampinas.org/2020/02/06/para-uma-historia-da-composicao-musical -em-campinas-2a-parte/.

"Carlos Gomes." In Wikipedia, March 8, 2016.

https://en.wikipedia.org/w/index.php?title=Carlos_Gomes\&oldid $=708981743$

Page Version ID: 708981743

Ciranda Cirandinha | Músicas Infantis | Cantigas de Roda. Accessed May 6, 2020. https://www.youtube.com/watch?v=V8JU4Q7hKe8.

Cultural, Instituto Itaú. "Damiano Cozzella." Enciclopédia Itaú Cultural. Accessed April 5, 2020.

http://enciclopedia.itaucultural.org.br/pessoa399022/damiano-cozzella

"Danças e Ritmos Do Brasil: Cana-Verde." Accessed May 6, 2020. https://dancasfolcloricas.blogspot.com/2011/03/cana-verde.html.

Deltregia, Claudia Fernanda. "O uso da música contemporânea na iniciação ao piano," 1999. http://repositorio.unicamp.br/jspui/handle/REPOSIP/284204 Accepted: 2018-07-25T17:26:48Z.

"Fandango No Paraná - Disciplina - Educação Física." Accessed May 6, 2020. http://www.educacaofisica.seed.pr.gov.br/modules/conteudo/conteudo.php?con teudo=31.

Fregoneze, Carmen L. "A Obra Pianística do Padre José Penalva”, Porto Alegre, 1992.

Gonçalves, Alexandre. "AS 3 SONATAS PARA PIANO DE JOSÉ PENALVA UMA ABORDAGEM ANALÍTICO-INTERPRETATIVA," Florianópolis, 2009. 
Gonçalves, Alexandre, e Guilherme Sauerbronn de Barros. "O dodecafonismo na Sonata n. 1 para piano de José Penalva," 2008, 7.

Guarnieri - Lais de Souza Brasil (1979) 50 Ponteios. Accessed March 15, 2020. https://www.youtube.com/watch?v=Whl704xXDE8.

“IMSLP42554-PMLP03090-Bartók-BagatellesOp6.Pdf.” Accessed July 9, 2020. http://ks4.ims/p.info/files/imglnks/usimg/d/df/IMSLP42554-PMLP03090-Bartok-B agatellesOp6.pdf.

Prof. André Egg. “José Penalva (1924-2002)," June 19, 2016. http://andreegg.org/2016/06/19/jose-penalva-1924-2002/.

“José Penalva, O Mestre Da Música” Parte 1-4. Accessed March 15, 2020. https://www.youtube.com/watch?v=KUzEZFw8Cuw.

Lago, Sylvio. Música Erudita Brasileira Gêneros e Formas. biblioteca24horas, 2016 Google-Books-ID: MPLzDAAAQBAJ

"Le Regard de Dieu" (Scriabin, Transcrição Para Coro José Penalva) - CD Madrigal Vocale Canta Penalva. Accessed April 22, 2020. https://www.youtube.com/watch?v=j9jAE5gYl_0.

Lima, Deise Maria. "Padre José Penalva: Uma Revisão Bibliográfica 1 Deise Maria de LIMA2 - Google Search." Accessed April 26, 2020. https://www.google.com/search?q=Padre+Jos\%C3\%A9+Penalva\%3A+uma+re vis $\%$ C3\%A3o+bibliogr $\%$ C3\%A1fica1+Deise+Maria+de+LIMA2\&rlz=1C1CHBF enUS731US731\&oq=Padre+Jos\%C3\%A9+Penalva\%3A+uma+revis\%C3\%A3o +bibliogr\%C3\%A1fica1+Deise+Maria+de+LIMA2\&aqs=chrome..69i57.524j0j8\& sourceid $=$ chrome \&ie $=$ UTF-8.

MADRIGAL VOCALE Canta LUIS IRUARRIZAGA (2). Accessed April 21, 2020. https://www.youtube.com/watch?v=YAYTBGtMy20. 
Moreira, Heron A.“Um panorama da obra pianística do Padre José Penalva com ênfase na interpretação da Sonata n. 1." Escola de música da UFRJ, Rio de Janeiro, 2004.

"Música Erudita Brasileira Gêneros e Formas - Sylvio Lago - Google Books." Accessed May 6, 2020.

https://books.google.com.br/books?id=MPLzDAAAQBAJ\&pg=PA116\&lpg=PA1 16\&dq=Folclore+brasileiro+ponteio\&source=bl\&ots=|4BuaTimQW\&sig=ACfU3U 3 HpvLOtivBHfVqV-bvosidYiZQ\&hl=en\&sa=X\&ved=2ahUKEwihyLTSmKDpA hUCA9QKHQLnB1UQ6AEwCnoECAKQAQ\#v=onepage\&q=Folclore\%20brasilei ro\%20ponteio\&f=false.

Oliveira, Jonathan Taylor de. "O cluster para piano na música brasileira dos séculos XX e XXI: formas de usar e escrever," 2013, 8.

PADRE PENALVA ENSAIA O MADRIGAL VOCALE EM 1994 (I). Accessed March 15, 2020. https://www.youtube.com/watch?v=LJDMjGvTzKU. Gazeta do Povo. "Padre Penalva ganha espaço dedicado à sua obra." Accessed April 13, 2020.

https://www.gazetadopovo.com.br/caderno-g/padre-penalva-ganha-espaco-ded icado-a-sua-obra-a0wjuikppjmijhu7fx2mxowgel.

“Penalva, José 1924-2002 [WorldCat Identities]." Accessed December 17, 2019. http://worldcat.org/identities/lccn-n86129107/.

"Programa_dia_25.03.2015.Pdf." Accessed April 22, 2020. https://files.cercomp.ufg.br/weby/up/269/o/Programa_dia_25.03.2015.pdf.

"Programa_dia_25.03.2015.Pdf." Accessed May 1, 2020. https://files.cercomp.ufg.br/weby/up/269/o/Programa_dia_25.03.2015.pdf.

Prosser, Elisabeth Seraphim. "AS APOSTILAS DE PENALVA SOBRE A MÚSICA DO SÉCULO XX: SISTEMATIZAÇÃO DIDÁTICA EM TEMPO REAL,” n.d., 9. Curitiba, Champagnat, 2000.

. "Um olhar sobre a música de José Penalva." 
Santos, Grasieli Cristina dos. "As Canções Para Voz e Piano de José Penalva: um estudo crítico-interpretativo." Scribd, 2012.

https://pt.scribd.com/document/264861162/As-Cancoes-Para-Voz-e-Piano-de-J ose-Penalva.

Santos, Grasieli Cristina Dos. "UNIVERSIDADE FEDERAL DO PARANÁ PROGRAMA DE PÓS-GRADUAÇÃO EM MÚSICA MESTRADO EM MÚSICA," 2012, 137.

"Serenata." In Wikipédia, a enciclopédia livre, November 22, 2019.

https://pt. wikipedia.org/w/index.php?title=Serenata\&oldid=56793141

Page Version ID: 56793141.

"Sonata N 11 - José de Almeida Penalva - GPPI - Grupo de Pesquisa em Práticas Interpretativas." Accessed April 3, 2020.

https://www.ufrgs.br/gppi/sonata-n-1-jose-de-almeida-penalva/.

"Sonata N 2 - José Almeida Penalva - GPPI - Grupo de Pesquisa em Práticas Interpretativas." Accessed December 17, 2019.

https://www.ufrgs.br/gppi/sonata-n-2-jose-almeida-penalva/.

"Sonata N 3 - José Almeida Penalva - GPPI - Grupo de Pesquisa em Práticas Interpretativas." Accessed April 3, 2020.

https://www.ufrgs.br/gppi/sonata-n-3-jose-almeida-penalva/.

Thompson, Ellen R. Teaching and Understanding Contemporary Piano Music. Kjos West, 1976.

"Viola caipira." In Wikipédia, a enciclopédia livre, February 18, 2020. https://pt.wikipedia.org/w/index.php?title=Viola_caipira\&oldid=57464887 Page Version ID: 57464887 